

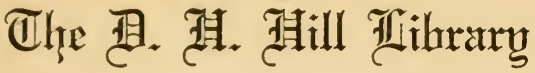

A̛orth Carolina State Uallege

$$
\begin{gathered}
\text { SB601 } \\
53
\end{gathered}
$$


wate NLC

\section{OCT 23-1953}

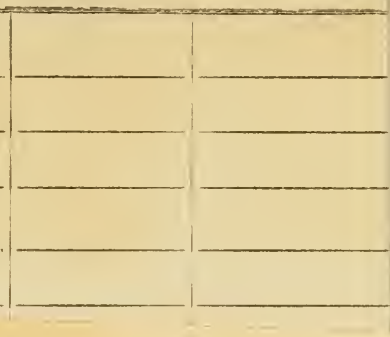

SB601

S3

16rog?

\section{Sanders, $T$.} Garden foes.

$$
\text { DATE }
$$

$17 \mathrm{Ju}^{\circ}$ 



\section{GARDEN FOES.}

Insect, Animal and Fungoid Pests Injurious to Fruit and Vegetable Crops, Hardy Plants, Trees, Shrubs and Greenhouse Plants, with all the Latest Remedies for their Eradication, Etc.

BY

\section{T. W. SANDERS, F.L.S., F.R.H.S.,}

Knight of the First Class of the Royal Order of Wasa, Sweden.

(Editor of "Amateur Gardening" and "Farm and Garden"; also Author of "An Encyclopzdia of Gardening," "Vegetables and their Cultivation,"

"The Flower Garden," "Alphabet of Gardening," "Roses and their Cultivation," "Bulbs and their Cultivation," Etc.)

\section{ILLUSTRATED.}

LONDON :

W. H. \& L. COLLINGRIDGE, 148 \& 149, Aldersgate Street, E.C. 


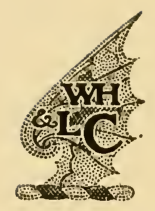

I.ONDON :

PRINTED BY W. H. AND L. COLLINGRIDGE, $14^{8}$ AND I49, ALOERSGATE STREET, E.C: 


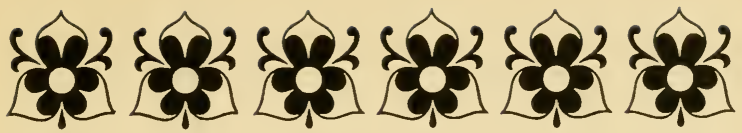

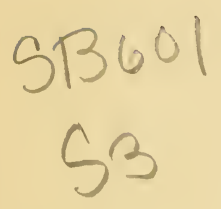

FOREWORDS.

Ever since the traditional fall of man successive generations of those whose business it is to till the soil for pleasure or profit have had to contend with hordes of insect, animal, or fungoid pests, ever on the alert to levy toll on bis crops, destroy them with innumerable diseases, or inflict such injury upon them as to lessen their value as food or their usefulness generally to mankind. It has ever been so, and will, no doubt, continue to be so for all time.

It is true in these modern times science has come to the assistance of the farmer and gardener, and educated both in more successful ways and means of coping with pests and diseases affecting our crops; and, consequently, we are in a much better position to prevent or cure the injuries arising, or likely to arise, therefrom than our forefathers were able to do. We know more of the life histories of insect and animal pests; also of the various fungi and bacteria that are productive of diseases, and it is therefore possible nowadays to adopt preventive measures to a large degree that will render our crops, our plants and our trees less liable to, if not wholly free from, attack and injury.

Take the case of our fruit crops, for example. Modern science has clearly demonstrated that, by the judicious spraying of the trees during the winter we may kill 
the millions of insect ova and larvie, and the plethora of mycelium of microscopic fungi infesting the shoots, branches, and trunlis, and only patiently awaiting the akrent of spring to develop their aggressive activities and inflict serious injury upon the foliage, shoots, blossoms, or fruit. It therefore behoves every fruit grower to adopt preventive measures, and so save his future crops and secure the health of his trees. It is useless waiting till insects or disease appear in summer. By that time both will have inflicted more or less injury which cannot be cured.

Science, too, has placed at our disposal much more crticient insecticides and fungicides than we had a few years ago. Those now available, and described elsewhere in this volume, if used intelligently and at the proper seasons, will enable the gardener effectually to banish pests and diseases, and maintain his crops and his plantis in a healthy condition, thus yielding him better results and greater pleasure than heretofore.

To the amateur gardener, more especially, the subject of pests and diseases affecting indoor and outdoor crops is naturally an object of great concern. Too frequently want of knowledge of the innumerable enemies, the proper remedies to apply, and the right time to use them, is a serious stumbling block to his success in the management of the garden or greenhouse. Of this fact we have convincing proof in the thousands of enquiries that reach Is in our capacity of Erlitor of "Amateur Gardening." Whe have therefore come to the conclusion that it would be of great assistance to amateur gardener's and others if we prepared a volume giving a descriptive account of the various pests and diseases affecting indoor and outdoor crops, and the most up-to-date remedies for their prevention or eradication.

The latter idea has developed into the present volume. Therein we have endeavoured, as far as possible, to deal with every phase of the subject of the enemies of crops. Thus in the firs' part we have supplied the most reliable 


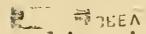

modern formulx for making insecticides and fungicides; the best apparatus for applying the latter; and clear instructions how to perform such important operations as spraying, fumigating, and cyaniding. In succeeding parts the pests and diseases of fruit crops, vegetable crops, hardy plants, etc., in the flower garden, greenhouse plants, and hardy trees and shrubs. In the final part such enemies of the garden as cats, moles, mice, rats, rabbits, and hares have had attention; also the subjects of lawn and path weeds. Nor have we overlooked the importance of pointing out the few friendly insects and animals which it is most desirable the gardener should learn to distinguish from the foes previously described.

Thus, we trust, the information we have given will enable every owner of a garden, greenhouse, or orchard to recognise the various pests and diseases that attack his crops, and to deal with them in an effectual manner, thereby preventing or arresting injury, and adding greater pleasures and joy to the task of managing them.

Finally, we have to acknowledge our indebtedness for information on many points to the numerous leaflets issued by the Board of Agriculture and Fisheries; Tubeuf and Smith's "Diseases of Plants"; Cooke's " Fungoid Diseases of Cultivated Plants"; Massee's "Diseases of Cultivated Plants and Trees" ; Theobald's " Insect Pests of Fruit"; and Curtis's "Farm Insects."

London, 1910.

T. W. SANDERS.

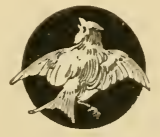




\section{FREE ON APPLICATION.}

\section{A COMPLETE}

CATALOGUE OF BOOKS

THE GARDEN, THE GREENHOUSE, FRUIT, VEGETABLES, LIVE STOCK, FARMING, MARKET GARDENING, SMALL HOLDINGS, Etc., Etc.

"Farm and Garden" Office,

148 \& 149, Aldersgate Street, London, E.C. 


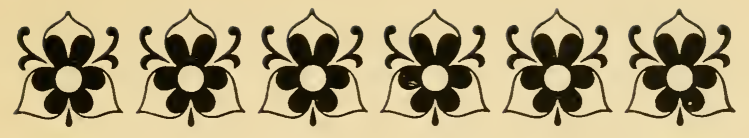

\section{CONTENTS.}

PART I.-REMEDIES, ETC.

PAGE

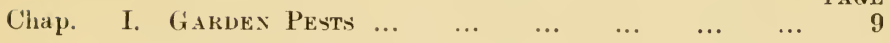

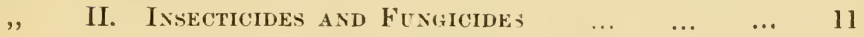

$\begin{array}{llllllll},, & \text { III. INSECTICIDE Formul.æ } & \ldots & \ldots & \ldots & \ldots & 15\end{array}$

$\begin{array}{lllllllll},, & \text { IV. Fungicide Formula } & \ldots & \ldots & \ldots & \ldots & \ldots & 24\end{array}$

,, V. Proprietaky Insecticides and Fuvilicides, Etc. 29

," VI. Spraytig Apparatus ...

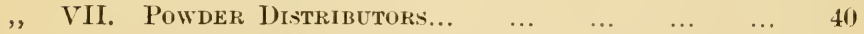

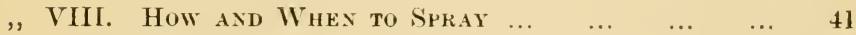

$\begin{array}{lllllllll} & \text { IX. Fumigativg } & \ldots & \ldots & \ldots & \ldots & \ldots & \ldots & 44\end{array}$

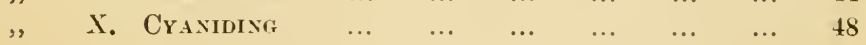

PART II.-FRUIT FOES.

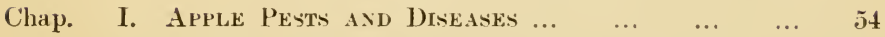

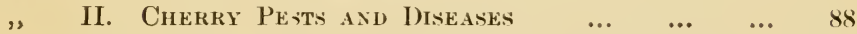

, III. Currant and Gooseberky Pests and Diseases 93

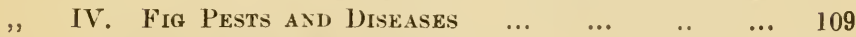

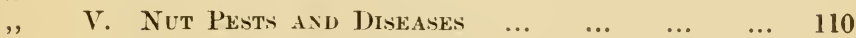

;, VI. Peach aNd Nectarise Pests and Diseases $\ldots . .113$

,. VII. Pear Pests and Diseases $\ldots$...

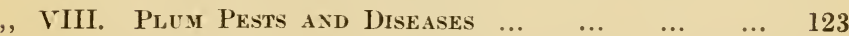

$"$ IX. Raspberry and Strawberry Pests and Diseases 128

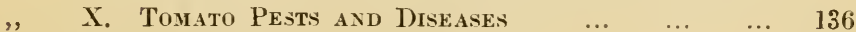

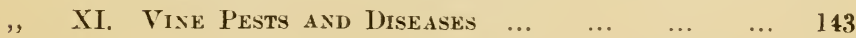




\section{P'ART III.-VEGETABLE FOES.}

PAGE

Chap. I. IXSECT AXn oTHER PESTS ATTACKIN: VEGETABLE

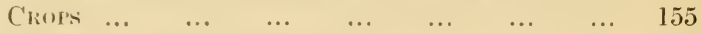

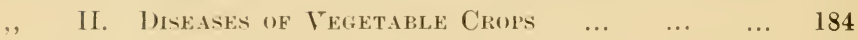

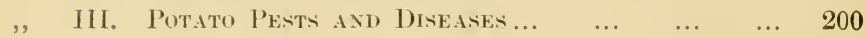

PART IV.-FLOIVER GARDEN FOES.

Chap. I. INenects Atтackist Phants ...

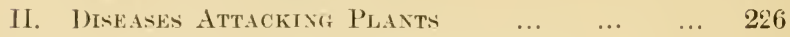

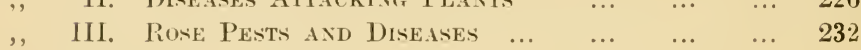

PART V.-GREENHOUSE FOES.

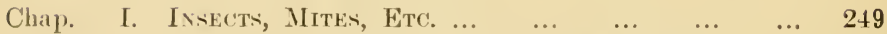

" II. Diseanes Attacking Greenifouse Plants $\quad \ldots \quad 267$

PART VI. - FOREST TREE FOES.

Chap. I. Insects Ixjurious to Forest Trees $\ldots$...

II. Diseases Ixfecting Forest Trees $\quad \ldots \quad \ldots \quad 289$

PART VII.-ODDS AND ENDS.

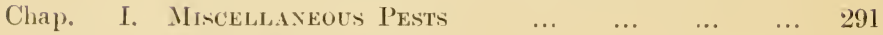

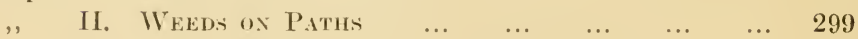

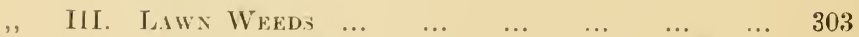

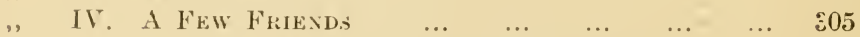

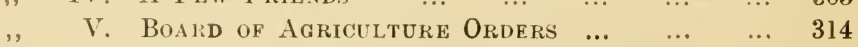




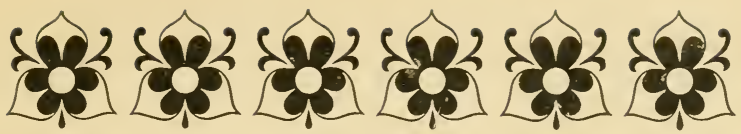

\section{Garden Foes.}

\section{Part I.-REMEDIES, ETC.}

\section{CHAPTER I.}

\section{GARDEN PESTS.}

These are divided into three distinct groups-1rsect, animal, and fungoid, and we will give a brief explanation of each to enable the inexperienced to differentiate between the three.

Insect Pests.--These include moths, butterflies, beetles, weevils, and fliers, and their larvie (caterpillars, grubs, or maggots). All insects go through four distinct stages of existence: First, they exist in the form of eggs; then change into larve (grubs or caterpillars); then into pupse; and, finally, into the imago, or perfect state. In the egg and pupal stages they do no harm to crops; in the larval stage they are most destructive; and in the perfect state some do harm and others not. The particular harm done by each pest is specified in the remarks referring thereto further on.

\section{PROPERTY LIBRART - State College}


Animal Pests. - These include millepedes, worms, slugs, snails, birds, cats, dogs, eelworms, hares, rabbits, and every other living creature which is developed from an egg or born alive, but which does not go through the four stages of development described in the preceding paragraph. Mites, again, do not belong to the insect tribe, but are included in the present category.

Fungoid Pests. - These are composed of minute or larger fungi which develop from spores or mycelium, and live on or in the tissues of living or dead vegetation. Fungi are of two types-parasitic, living on living tissue, as mildew; or saprophytes, living on dead tissues. There is a third class, called slime fungi, of which the Finger and Toe disease is an example; but mycologists are doubtful about these being true fungi. Then again, there are bacteria, minute organisms which produce disease somewhat similar to that caused by true fungi.

Blights.-Many gardeners and country folk use the term "blight" as signifying any disease or insect infestation of their crops. This, however, is a loose and vague term. The so-called "blight" is really the injured state of the growth crippled by frost, by cold winds, or by insect and fungoid pestis. When "blight" is spoken of the true cause must be sought for in one of the numerous pests hereafter described.

A Word of Caution.-Whenever anything is detected amiss with a plant or crop, take the earliest opportunity to find out the cause, and apply the remedy at once. Delay is dangerous. In a few hours or a few days the pest will seriously cripple the growth, and no remedy in the world can then repair the damage done.

You may, it is true, get rid of the cause, but you cannot easily cure the after-effects. Growths barlly infested with fungoid or insect pests should be promptly removed and speedily burnt. Never throw diseased roots, leaves, or 
shoots on the ground, otherwise the fungus will fructify and produce spores or mycelium that will later on attack the next crop.

If everyone would make a point of burning every scrap of diseased plant directly it is seen, many diseases would be soon stamped out. The day will come, let us hope, when it will be a penal offence to allow diseased plants, ete., to continue to grow and spread further destruction.

No matter how valuable a plant may be, it is unwise to try to save it if badly diseased. Remember, each solitary insect is capable of propagating its species largely, and each individual patch of fungi to develop millions of spores to be carried by the agency of birds, insects, wind, etc., to other and healthy crops.

Surely, but swiftly, all pests should be destroyed at the earliest moment, and then the gardener will meet with less worry, and his crops enjoy greater freedom from pests and disease.

CHAPTER II.

\section{INSECTICIDES AND FUNGICIDES.}

\section{PRINCIPAL INGREDIENTS.}

Below we give a brief description of the principal materials for making insecticides and fungicides.

Hydrocyanic Gas.-This is produced by mixing either potassium cyanide (98 per cent.) or sodium cyanide (130 per cent.) with sulphuric acid and water. The resulting gas is a deadly poison, and will cause death if inhaled. See chapter on "Cyaniding." Caution: The cyanide must 
not come in contact with the acid while human beings are present. (See Chapter X., Part I.)

Carbon Disulphide.--A combination of sulphur and carbonic acid. It is highly volatile and poisonous. Must not be used near a naker light, cigarette, cigar, or pipe. Gives off fumes destructive to insect life when buried in the soil.

Caustic Soda.-A form of soda possessing caustic properties. The best form of it to use for insecticides is commercial caustic soda (98 per cent. purity). It readily dissolves in cold water, and also absorbs moisture, and becomes soft or liquid when exposed to the air. Requires to be kept in tightly-closed iron cans. Will burn flesh if permitted to touch it. Should be handled only with protected hands. That sold in powdered forms in tins is best.

Potassium Carbonate (Carbonate of Potash). - A form of potash used for making insecticides for winter use. Commercial potassium carbonate (80 per cent.) is the best form to use. Pearlash and salts of tartar are other names used for it. The form and strength mentioned is, however, the one to procure and use. It is dearer than caustic soda.

Quassia.-This consists of chips of yellow wood obtained from the trunks of a West Indian tree, named Picrena excelsa. When infused in water it produces a bitter fluir. The bitter extract may be obtained by infusing the chips in cold water for twenty-four hours or boiling in water for two hours. Fxtract of quassia and quassine are concentrated preparations of it. Used in conjunction with soft soap.

Soft soap. - This is a preparation of soap obtained by chemically treating oil with potash. The best strength to 
use for insecticides is that which contains 8 per cent. potash. Soft soap dissolves more quickly in hot than cold water.

Pyrethrum Powder. - A product obtained by grinding the buds or the flowers of a species of pyrethrum to a fine powder. Used largely for making insect powders.

Hellebore Powder. - A subistance prepared by grinding the roots of the False White Hellebore (Veratrum album) to a fine powder. It is poisonous, and must not be inhalerd. To avoid injury to the operator it is best mixed with water before using.

Paris Green.-This is known as an arsenical insecticide (aceto-arsenite of copper). The best form of it to use is Blundell's Paris Green, a preparation sold in powder and paste form. The latter is the safest to use, as the powder, if inhaled, is highly poisonous. Requires to be applied in a very fine, mist-like spray. A splendid insecticide for fruit trees. Not soluble in water; can only be mixed with it.

Arsenate of Lead.-A combination of acetate of lead (98 per cent.) and arsenate of soda (98 per cent.). The two require to be dissolved in water, as advised further on.

Kerosene.-An American oil; also known as paraffin and petroleum oil. Used in conjunction with soft soap and boiling water to form an emulsion. Requires whilst hoiling hot to be beaten into a creamy-white fluid. May be stored in corked tins or jars for years.

Nicotine.-An extract of tobacco used for making various fumigating compounds. A deadly poison. Tobacco juice, made by steeping tobacco in boiling water, is a less concentrated form of it. 
Carbolic Acid.-A dark, oily liquid; is sometimes used as an insecticide; but, being a dangerous poison and uncertain in strength, is best avoided. Formalin, Lysol, and Phenol are forms of this acid. Carbolic soap is sometimes used in solution with water as an insecticide.

Potassium Sulphide (Liver of Sulphur).-An evilsmelling chemical, much recommended as a remedy for mildew and other minute fungi. It rapidly decomposes when exposed to the air, so should be kept in tightlycorked bottles. Discolours white paint.

Copper Sulphate (Sulphate of Copperas).-A chemical sold in hard blue crystals; a corrosive, irritant poison. The proper strength to use is 98 per cent. Must not be dissolred in metal ressels, only in wooden ones.

Iron Sulphate (Sulphate of Iron). - A chemical sold in pale green crystals. Used in conjunction with sulphuric acid and water. Must be mixed in wooden vessels only. Is apt to destroy clothing, and is otherwise an objectionable fungicide to use.

Sulphur.--The form in which this is used as a fungicide is "flowers of sulphur." It is composed of sulphur precipitated into a fine powder, and is non-poisonous unless heated over a fire. It may be used alone or in combination with lime and salt. As a remedy for mildew it is excellent.

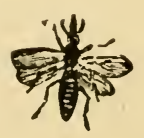




\section{CHAPTER III.}

\section{INSECTICIDE FORMULAE.}

Below we give the chief formulæ for washes for winter, spring and summer spraying, as recommended by leading experts.

\section{WINTER WASHES.}

These are to be used whilst growth is dormant only, and for the purposes specified in comnection with each.

1. Caustic Alkali Wash.-There are several ways of preparing this solution, and the grower can choose the one for which he can obtain the ingredients most easily.

(a) Caustic soda (98 per cent. purity) $\ldots{ }^{2} \ldots 1 \mathrm{lb}$. Caustic potash (80 per cent. purity) _. $1 \mathrm{lb}$. Agricultural treacle $\ldots \begin{array}{llllll} & \ldots & \ldots & \ldots & \ldots & \frac{3}{4} l b .\end{array}$ Water to make up to $\quad \ldots . \quad \ldots \quad \ldots \quad \ldots 10$ gal.

Dissolve the potash and soda separately in two wooren bucliets with a little water. Solution of these two chemicals usually takes place with considerable violence and the production of great heat, but if it is slow in starting the addition of a very little hot water will have the desired effect. Mix the two solutions together, and stir in the treacle, and make up to 10 gallons for use. If a stock solution is to be kept to do a few odd trees at different times, make up to only one gallon, and put in a bottle fitted with an indiarubber cork. One part of this solution will require nine parts of water to bring it to the correct spraying strength.

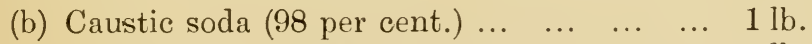

Carbonate of potash ( 80 per cent.) $\ldots . \quad \ldots \quad 1 \mathrm{lb}$.

$\begin{array}{lllllllll}\text { Soft soap } & \ldots & \ldots & \ldots & \ldots & \ldots & \ldots & \ldots & \frac{1}{2} \mathrm{lb} .\end{array}$

$\begin{array}{llllllll}\text { Water to make } & \ldots & \ldots & \ldots & \ldots & \ldots & \ldots & 10 \\ \text { gal. }\end{array}$ 
Dissolve the soft soap) in some of the water, and ard to the soda and potash when dissolved.

Usks.-Cleansing trees from moss and lichen, and killing Sicale and other insect ova.

'lime to Aprey.-Norember to March.

2. Woburn Winter Wash.-A wash recommended by Mr. Spencer U. Picliering, F.R.S. (Director of the IVoburn Fxperimental Fruit Farm):

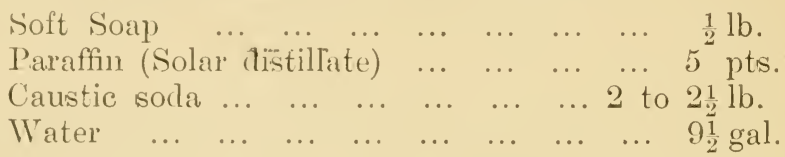

J)issolve the soap in hot or cold water (hot preferably), then ardel the paraffin and thoroughly mix, after which gradually add the soda. Stir continually during use.

Uses.-Same as No. 1.

The to Apply.-November to March.

3. Another Woburn Formula.-Mr. Spencer U. Pickering discovered that by adding copper sulphate to above formula the wash required less constant stirring, while it also acted as a fungicide:

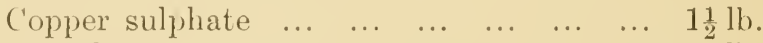

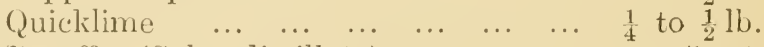

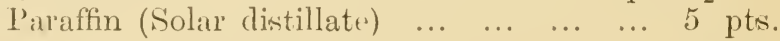

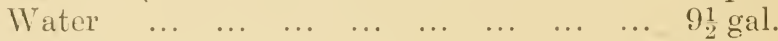

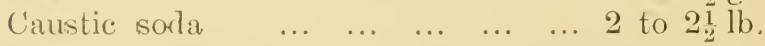

Prepare as advised in formula No. 2, adding the soda gradually last of all.

Uses.-Precisely as advised for No. 1.

'Thue to Aprix.-November to March.

4. A Cheaper Formula.-The same authority recommends the following formula as being cheaper and quite as effectual, but possessing no fungicidal properties: 
$\begin{array}{llllllll}\text { Iron sulphate } & \ldots & \ldots & \ldots & \ldots & \ldots & \ldots & \frac{1}{2} \mathrm{lb} .\end{array}$

Quicklime

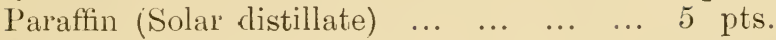

$\begin{array}{llllllllll}\text { Water } & \ldots & \ldots & \ldots & \ldots & \ldots & \ldots & \ldots & \ldots & 9 \frac{1}{2} \text { gal. }\end{array}$

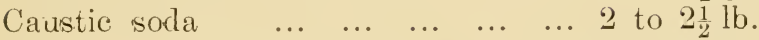

Dissolve the iron sulphate in water, slake the lime in a little water, then add more water and strain the solution through a fine sieve into the iron solution. Adrd the paraffin, and churn thoroughly, finally adding the soda.

Usas.-For cleansing trees of mass and lichen, Mussel Sicale, insect ora, etc.

Tine to Apply.-November to March.

5. Lime-Sulphur - Soda Wash.-This is an excellent winter wash, much used in the United States, and known as the Oregon Wash:
Lime
$3 \mathrm{lb}$.
Sulphur
Salt
$3 \mathrm{lb}$.
$\begin{array}{lllllllll}\text { Caustic soda } & \ldots & \ldots & \ldots & \ldots & \ldots & \ldots & \ldots & 1 \mathrm{lb} .\end{array}$
$\begin{array}{llllllllll}\text { Water } & \ldots & \ldots & \ldots & \ldots & \ldots & \ldots & \ldots & \ldots & 10 \text { gal. }\end{array}$

Mix the lime and soda together, and slake with hot water in which the sulphur has previously been incor poratel. Stir well, and add the salt; then the mixture will generate heat and boil for some time. When this ceases ardd water to make ten gallons.

Uses. - A remedy for the Pear Blister Mite, Mussel and Oyster Scale ova.

Tine to Apply.-November to March.

6. Winter Wash for Indoor Fruit Trees.-This is known as the Paraffin-Naphthaline Solution. Put into a boiler 10lb. of soft soap, add 3 pints of water, and heat gently till quite liquid. Put $2 \frac{1}{2}$ pints of paraffin into another vessel, and stand it in the hot liquid, keeping the fire very low. Into the paraffin put $1 \mathrm{lb}$. of stick naphthaline, and stir till dissolved. Remove all from the fire, and whilst stirring the soap rapidly pour the paraffin solution slowly in, and stir until a good emulsion is formed. 
The resulting grease-like mass can be stored in a tin till winted.

Uses.-Half a pound of the mixture dissolved in hot water and made up to three gallons is the strength for ordinary use on green leaves; $1 \frac{1}{2} \mathrm{lb}$. to 3 gallons will not liurt for dormant vines and peaches. For washing glass and woodwork the stronger the better. It can be applied ats a coarse spray, and then be followed with the syringe and clear water. A good remedy for red spider.

Time to Apply.--After the leaves have fallen, and before growth begins in the case of the strong solution, and in summer for the weak solution.

\section{A Simple Winter Wash for a Few Trees. -}

If a small number of trees are to be sprayed, and the caustic potash and soda are difficult to obtain in the right strength locally, the solution may be made as follows:

$\begin{array}{llllllll}\text { Washing soda } & \ldots & \ldots & \ldots & \ldots & \ldots & \ldots & 2 \frac{1}{2} \mathrm{lb} \text {. }\end{array}$

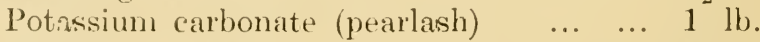

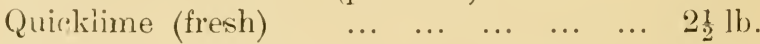

$\begin{array}{lllllllll}\text { Soft } \operatorname{soap} & \ldots & \ldots & \ldots & \ldots & \ldots & \ldots & \ldots & \frac{1}{2} \mathrm{lb}\end{array}$

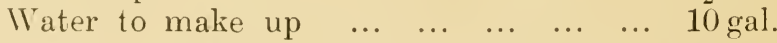

Slake the lime to a fine powder with a little water, and then mix to a thin cream. Add the soda and potash, and stir well till dissolved. Add the soft soap dissolved in some more water, and make up to 10 gallons; stir well, and then allow the lime to settle. Pour off the liquid for use.

UsEs. - For destroying moss, lichen, insect ora, etc.

Time to Apply.-November to March.

8. A Winter Spray-fluid (brought out and highly recommented by $\mathrm{Mr}$. Strawson) is as follows:

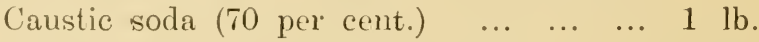

Carbonate of potash (80 per cent.) $\ldots . \quad \ldots \quad 1 \quad$ lb.

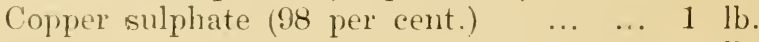

$\begin{array}{lllllllllll}\text { Treacle } & \ldots & \ldots & \ldots & \ldots & \ldots & \ldots & \ldots & \ldots & 1 & \mathrm{lb} .\end{array}$

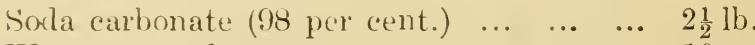

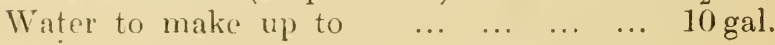


The caustic sola, potash, and treacle are dissolved together in a gallon or two of water. The copper sulphate and carbonate of soda are also dissolved separately, then mixed. The copper sulphate is dissolved in a ressel large enough to hold the complete solution, and the soda carbonate added slowly to it, and then the caustic sorla and the potash, stirring all the time. The mixture should be kept mixed whilst spraying. Wooden vessels should be used for copper sulphate or any of the caustic alkali solutions. Iron ones are rapidly spoiled unless enamelled. Great care should be taken not to get caustic alkali on the skin, and the face and hands should be kept greased with vaseline while using the sprayer. Painful burns result if the spray is allowed to dry on.

Uses.--Same purposes as No. 1.

'Ine ro Aprey.-- Winter only.

\section{SPRING AND SUMMER WASHES.}

9. Lime and salt wash.-A wash highly recommended by many experts:

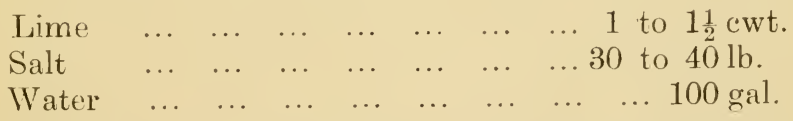

First slake fresh lime and mix it with 50 gallons of water, and in the remaining 50 gallons dissolve the salt; then mix the two. Some authorities recommend the addition of $\frac{1}{2}$ to $1 \mathrm{lb}$. of waterglass (sodium silicate), but it appears this is not essential. The mixture requires to be strained through a very fine sieve before using.

Uses.-For cleansing trees of moss, lichen, and alga, and destroying the ova of the Apple Sucker (Psylla), Plum Aphis, Mussel Scale, etc.

Time to AppLY.--From the end of February to the beginning of April. Must not be used after the buds open. 
10. Arsenate of Lead Wash.-A capital wash for destroying all biting insects, as caterpillans and beetles:

$\begin{array}{llllllll}\text { Arsenate of soda } & \text { (pure) } & \ldots & \ldots & \ldots & \ldots & 3 \frac{1}{2} \mathrm{oz} . \\ \text { Acetate of lead } & \ldots & \ldots & \ldots & \ldots & \ldots & \ldots & 7 \\ \text { Waz. }\end{array}$

Dissolve in water and thoroughly mix; then add 1lb. of treacle, to cause the wash to adhere to the trees. This wash is to be obtained ready prepared under the name of Swift's Arsenate of Lead Paste. Poisonous.

Uses. - A good remedy for destroying the larve of the Winter, Codlin, Lackey, and Currant Moths; also Gooseberry Sawfly and Slugworms.

Trme to Apply. - When the buds finst show signs of bursting; again when the petals fall; and again a few weelis later to destroy Vapourer Moth larve.

11. Paris Green Wash.-Another arsenical wash of special value for destroying all biting insects. It is prepared in two ways-(a) by means of Paris green in powrler form, and (b) by means of a paste known as Blundell's Paste. As the powder is very poisonous, and liable to be inhaled, it is safer to use the paste form.

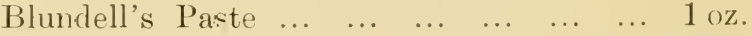

$$
\begin{aligned}
& \begin{array}{lllllllll}
\text { Wrater } & \ldots & \ldots & \ldots & \ldots & \ldots & \ldots & \ldots & 10 \text { gai. }
\end{array} \\
& \begin{array}{llllllllll}
\text { Lime } & \ldots & \ldots & \ldots & \ldots & \ldots & \ldots & \ldots & \ldots & 4 \mathrm{oz} .
\end{array}
\end{aligned}
$$

Mix the paste with the water, then add the lime and keep constantly stirred whilst using, or the Paris Green will sink to the bottom of the sprayer.

Uses.-For destroying Caterpillars and Beetles. If used on peach, nectarine, or apricot trees add $\frac{3}{4} \mathrm{oz}$. of paste only to 10 gals. of water.

Time to Apply. - Same as advised for Formula Nos. 10 and 11. Do not apply when trees are in flower.

12. London Purple Wash.-Also an arsenical wash used for precisely the same purpose as Nos. 10 and 11. As Nos. 10,11 , and 12 are deadly poisonous substances, cattle, horses and fowls should not have access to the liquids; 
nor is it adrisable for them to be allowed in orchards until a few weeks after application. These washes must not be applied to trees having an undercrop of currants, gooseberries, or strawberries later than a month before gathering the fruit.

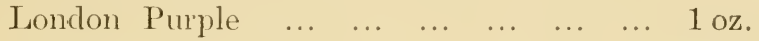

$\begin{array}{llllllllll}\text { Lime } & \ldots & \ldots & \ldots & \ldots & \ldots & \ldots & \ldots & \ldots & 1 \mathrm{oz} .\end{array}$

$\begin{array}{lllllllll}\text { Water } & \ldots & \ldots & \ldots & \ldots & \ldots & \ldots & \ldots & 10 \\ \text { gal. }\end{array}$

Mix as advised for Formula No. 11.

Uses. - Same as Nos. 10 and 11.

Time to Apply.-Same as Nos. 10 and 11.

\section{MISCELLANEOUS INSECTICIDES.}

13. Tobacco Water.-Boil 4oz. of shag tobacco in a gallon of water for half an hour; strain off the liquor, and use when cold.

Uses.-As a remedy for Greenfly on greenhouse and window plants or roses.

Trme to Appur. - When insects infest the foliage.

14. Quassia and Soft Soap.-The best-known of the home-made sprars for garden and greenhouse use:

$\begin{array}{llllllllll}\text { Quassia } & \ldots & \ldots & \ldots & \ldots & \ldots & \ldots & \ldots & \ldots & 1 \mathrm{lb} . \\ \text { Soft soap } & \ldots & \ldots & \ldots & \ldots & \ldots & \ldots & \ldots & 1 \mathrm{lb} . \\ \text { Water } & \ldots & \ldots & \ldots & \ldots & \ldots & \ldots & \ldots & \ldots & 10 \text { gal. }\end{array}$

The quassia should be boiled with half the soap and half the water for about one hour, and then the liquid poured off and the boiling continued with the remainder of the soap and water for another hour, the two solutions being added together for spraying. Soft soap by itself, $211 \mathrm{lb}$. to 10 gallons water, is often used.

Uses.-For ridding plants, roses, etc., of Aphides.

Tine to Apply. - In summer.

15. Hellebore Wash.-A cheap and easily-made insecticide for destroying caterpillass on gooseberry and currant bushes. 


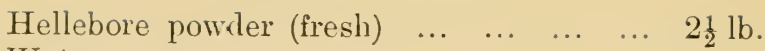

$\begin{array}{llllllllll}\text { Water } & \ldots & \ldots & \ldots & \ldots & \ldots & \ldots & \ldots & \ldots & 10 \\ \text { gal. }\end{array}$

Or:

\begin{tabular}{lllllll} 
Pyrethrum powrler & $\ldots$ & $\ldots$ & $\ldots$ & $\ldots$ & $\ldots$ & 21 \\
\hline
\end{tabular}

$\begin{array}{llllllllll}\text { Water } & \ldots & \ldots & \ldots & \ldots & \ldots & \ldots & \ldots & \ldots & 10 \\ \text { gal. }\end{array}$

These two mixtures must be liept well stirred during use.

UsEs.-See above remarks.

Time to Apply. - A month before gathering the fruit, as the hellebore powder is poisonous.

16. Kerosene Emulsion. - The Hubbard-Riley kerosene emulsion, one of the most useful stock solutions to have on hand, is made as follows:

lierosene oil $\ldots \begin{array}{llllllll}\ldots & \ldots & \ldots & \ldots & \ldots & \ldots & \ldots & 2 \text { gal. }\end{array}$

$\begin{array}{llllllll}\text { Boiling water } & \ldots & \ldots & \ldots & \ldots & \ldots & \ldots & 1 \text { gal. }\end{array}$

Soft soap (8 per cent.) $\quad \ldots \quad \ldots \quad \ldots \quad \ldots \quad \frac{1}{2} \mathrm{lb}$.

The soap is dissolved in the water, and when still boiling is poured into the oil and beaten up well until a creamy liquid is formed and the mixture begins to cool. It is then poured into a sprayer and sprayed back into the ressel through a fine nozzle, using as much power as possible. This forms the stock solution, which can be kept bottled for use. It is mixed with water in proportion to suit its purpose, from one part emulsion to 50 parts water for greenfly on tender subjects, to one part in two for brushing on American blight. It is quite safe to use as long as it remains an emulsion and no oil separates ont.

Uses.-For destroying Greenfly and American Blight; also Caterpillars.

Time to Aprly.-Spring or summer.

17. Tar Water.-A simple but effective remedy for plints attacked by leaf miners is tar water, prepared by boiling hard $\frac{1}{2} l b$. of tar in one gallon of water for twenty 
minutes, and then suddenly turning it into 50 gallons of cold water and stirring thoroughly. It has been used successfully on cinerarias and marguerites. The sprayings were made five or six times during the season. Growers of celery might try it against the Celery Fly which causes so much damage to the crop.

Uses.-.-See above remarks.

Time to APply.-Spring and summer.

18. Powder Insecticides.-The use of fungicides and insecticides in the form of fine powders applied in the dry state is not very widespread, and in this country is almost confined to the application of sulphur or lime and sulphur mixed. The writer has tried a mixture of strawsonite and lime (slaked and sifted finely) on potatoes, with very good results in protecting the crop from disease. A mixture of two parts sulphur to one of slaked lime has been recommended by the Board of Agriculture for the treatment of Onion Mildew. The best way of applying the powder is by means of a powder pump, at least two malies of which are to be had in the handy knapsack form. 'The lime-and-sulphur mixture is most useful for dusting among plants to prevent damping off. Pyrethrum powder and hellebore are also applied dry in some cases.

Time to Apply.-In summer.

19. Soil Disinfectants.-Following are remedies for disinfecting soil in which diseased tomatoes or plants have been grown: Carbolic, 1 gallon to 50 gallons of water, used when the land can be allowed to rest for one month before the next crop. Permanganate of potash, 1lb. to 50 gallons of water. Planting may take place as soon as the borders are dry enough. The writer has watered a tomato growing in a pot with this strength, giving three waterings, one after the other, without hurting the plant. One pound of permanganate to 100 gallons of water may be safely used for watering purposes, and will be beneficial to the crop. 


\section{FUNGICIDE FORMULAE.}

THE following are excellent formulie for the preparation of effective fungicides:

20. Bordeaux Mixture.-One of the most important of all the fungicides, and the most widely used, is Bordeaux Mixture:

$\begin{array}{llllllll}\text { Copper sulphate } & \ldots & \ldots & \ldots & \ldots & \ldots & \ldots & 2 \mathrm{lb} .\end{array}$

$\begin{array}{lllllll}\text { Fresh-burned lime } & \ldots & \ldots & \ldots & \ldots & \ldots & 2 \mathrm{lb} .\end{array}$

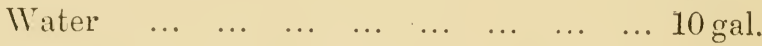

The copper sulphate is dissolved in about half the water in a wooden ressel, large enough to contain the whole; and the lime is dissolved in another smaller one. When the copper sulphate is dissolved and the lime has settled after being slaked and well stirred up in the water, the clear lime water is added to the copper sulphate until the liquid, on allowing the blue precipitate which is formed to settle, will not turn blue litmus paper red, or will give no brown discoloration on the addition of 10 per cent. solution of potassium ferrocyanide. A useful way of having Bordeaux mixture ready at shoit notice is to keep a stock solution of copper sulphate of $3 \mathrm{lb}$. to the gallon of water. This is what is known as a saturated solution, and as long as a greater amount of copper sulphate than this $31 \mathrm{lb}$. to the gallon is kept hanging in the water the solution will remain the same strength at all ordinary temperatures. If any of the water evaporates crystals of copper sulphate will be deposited until the liquid gets to its right strength, and if more water is added more of the salt will be dissolved to restore the 
balance. Note: The surplus copper sulphate must hang near the surface of the water in an open-work bag, and not be thrown to the bottom of the vessel. The lime can be kept caustic for some weeks if it is slaked, made into a stiff paste, and stored in an old barrel and kept just covered with a little water. The advantage of this method is obvious. Every gallon of the copper sulphate solution being known to contain 3lb. of the chemical, it only requires that it be diluted with water, and have added to it some lime water prepared from the paste in the barrel until the tests before-mentioned are complied with, and then the mixture can be made up with water to the proper strength-that is, every gallon of copper sulphate at $3 \mathrm{lb}$. to the gallon will make 15 gallons of Bordeaux mixture ready for use.

Uses.--As a remedy for the Potato Blight, Apple and Pear Scab, Cucumber and Melon Mildew, Peach-leaf Curl, Apple Mildew, Cherry-leaf Scorch, Tomato-leaf Rust, etc.

True to Apply.--See notes in connection with each disease.

21. Woburn Bordeaux Emulsion. - The following formula has been derised and recommended by Mr. Spencer U. Pickering, M.A., F.R.S., Director of the IVoburn Experimental Fruit Farm, as an excellent combined insecticide and fungicide:

$\begin{array}{lllllllll}\text { Copper sulphate } & \ldots & \ldots & \ldots & \ldots & \ldots & 10 & \mathrm{oz}\end{array}$

$\begin{array}{lllllllll}\text { Lime water } \ldots & \ldots & \ldots & \ldots & \ldots & \ldots & \ldots & 81 & \text { gal. }\end{array}$

Water to make up to nearly $\quad \ldots \quad \ldots \quad \ldots 10$ gal.

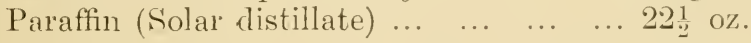

The above paraffin is sold by dealers in fungicides under the name of Woburn Distillate, and is not inflammable. This emulsion should be prepared as advised for Bordeaux Mixture. Before using see that the mixture is well churned. The foregoing may be purchased ready prepared under the name of Woburn Bordeaux Emulsion 
Uses.-Sime as for Bordeaux Mixture.

Time to Apply.-See notes in connection with each disease.

\section{Ammoniacal Copper Carbonate Solution.}

- Allied to Bordeaux Mixture, and chiefly used in greenhouse work. The solution is prepared as follows:

Carbonate of copper $\ldots \begin{array}{lllllll} & \ldots & \ldots & \ldots & \ldots & 1 \mathrm{oz} .\end{array}$

Carbonate of ammonia $\quad \ldots \quad \ldots . \quad \ldots \quad \ldots \quad 5 \mathrm{oz}$.

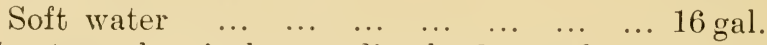

The two chemicals are dissolved together in about a quart of hot water, and stirred until a clear blue liquid is formed, and then the remainder of the water is added for spraying. If desired, the strong solution can be kept bottled, and if the above quantities when dissolved are made up to three pints, a Winchester quart bottle will hold it nicely, and a convenient strength for dilution is formed-viz., one part of the stock solution to 40 parts of water. Many writers advise its use because it leaves very little deposit. This is pernicious advice; all fruit should be wiped before marketing where poisonous fungicides have been used, especially when grown under glass.

Uses.-For spraying tomatoes in the open or under glass, for the prevention of various fungoid diseases.

Time ro Apply.-In spring or summer, either before disease appears or directly afterwards.

23. Potassium Sulphide.-A well-known fingiciale, and one much used, is potassium sulphide, strength $\frac{1}{2} \mathrm{Oz}$. to the gallon of water. It is best fresh made, but a stock solution kept in the dark and well corked will keep good a long time. If $1 \mathrm{lb}$. of the sulphide is dissolved and made up to three pints it can be stored in bottles, and two fluid ounces of it used to every gallon of water for spraying. Potassium sulphide requires boiling to dissolve it, and this cperation must take place in an enamelled saucepan, or the chemical be put in a jar stoor in boiling water. Add the whites of two eggs to the solution to cause it to 
adhere more readily to the foliage. It will quickly spoil any thin iron ressel. It discolours paint, and has an objectionable smell.

Uses.--An excellent remedy for mildew on roses; also for many other fungoid diseases mentioned in this volume.

Tiмe to APPl.Y.-In spring or summer.

24. Vioiet Fungicide.-Another little-known fungicide, but one said by its inventor, Dr. C. Nouchat, to be superior to Bordeaux mixture, is the violet fungicide: $3 \mathrm{lb}$. 4oz. sulphate of copper, and 5lb. $8 \mathrm{oz}$. carbonate of copper, dissolved in 22 gallons of water. To this is added 1oz. of permanganate of potash dissolved in one quart of water.

UsEs. - As a remedy for the various fungoid diseases of the violet, pansy, and viola.

Time то Appry.-When the fungi first attack the plants.

\section{Cupram, or Copper Carbonate.-According} to Mr. Spencer U. Pickering, in his useful little work "Fruit Trees and their Enemies," the following is a good formula for making this fungicide:

$\begin{array}{lllllll}\text { Copper carbonate } & \ldots & \ldots & \ldots & \ldots & \ldots & 1 \frac{1}{4} \mathrm{cz} .\end{array}$ $\begin{array}{lllllll}\text { Strong ammonia } & \ldots & \ldots & \ldots & \ldots & \ldots & 16 \text { liquid } \mathrm{oz} .\end{array}$

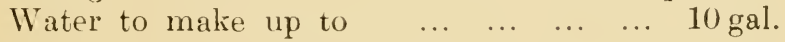

The ammonia to be diluted with 12 pints of water, the copper carbonate added, and the whole well shaken till the latter is dissolved, when make up to 10 gallons with water. This fungicide is less liable to injure delicate foliage than Bordeaux Mixture.

UsEs. - A remedy for mildew on roses under glass or in the open; also for peaches and nectarines attacked by mildew, the Shot-hole Fungus, and Peach-leaf Curl.

Time to Apply.-Apply in summer, except in case of Peach-leaf Curl, when apply at pruning time. 
26. Sulphate of copper.- 1 good fungicide to spray rose trees with in winter as a preventive of Mildew, Black Spot, and Rose-leaf Scorch:

Copper sulphate $\ldots \begin{array}{lllllll} & \ldots & \ldots & \ldots & \ldots & \ldots & 10 z .\end{array}$

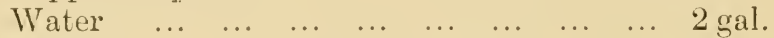

Place the sulphate in a coarse bag and suspend it in a wooden, not a metal, pail until it has dissolved.

UsEs. - For mildew on roses, etc.

Time то Apply.-Winter, when growth is dormant.

27. Lime - Sulphur Spray.--An American fungicide said to be most efficacious in checking Apple and Pear Scab, Leaf Spot, Mildew, etc

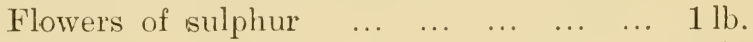

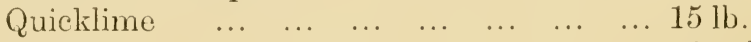

$\begin{array}{llllllllll}\text { Water } & \ldots & \ldots & \ldots & \ldots & \ldots & \ldots & \ldots & \ldots & 50 \\ \text { gal. }\end{array}$

Place the lime in a wooden barrel or tub, pour three gallons of boiling water over it, then add the sulphur and three more gallons of boiling water. Cover the barrel or tub with a sack, when the mixture will boil of its own accord for twenty minutes. Stir occasionally during that time. As soon as the boiling ceases add water to make up to 50 gallons, then strain through a sieve having 20 meshes to the square inch, to remove the large particles of lime, but not the sulphur.

Uses. - See remarkis above.

Time to Apply. - Spring or summer.

28. Flowers of Sulphur. - In old and excellent remedy for mildew indoors or out. Apply at any time by means of a diedger, bellows, or distributor, to the foliage. On no account burn sulphur unler glass, or the fumes will destroy regetation.

29. Iron Sulphate Solution.-An excellent fungicide for spraying walls, beds, etc., of greenhouses in which diseased tomatoes have been grown: 


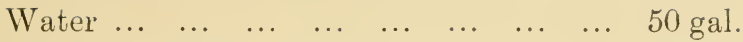

$\begin{array}{llllllll}\text { Sulphuric acid } & \ldots & \ldots & \ldots & \ldots & \ldots & \ldots & 1 \text { pint. }\end{array}$

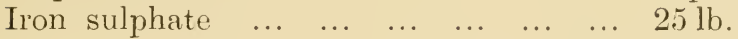

The acid should first be poured over the iron sulphate placed in a wooden, not a metal, vessel, and then the water be gradually and very cautiously added.

Uses. - For purposes named above, and others mentioned in connection with diseases described further on.

Time to Apply.-Winter.

CHAPTER V.

\section{PROPRIETARY INSECTICIDES AND FUNGICIDES, ETC.}

Is this chapter we propose to describe a few of the specially-prepared insecticidies and fungicides on the market, in order that those who do not care to undertake the trouble and time recessary to make their own preparations from the formulæ given in preceding chapters may know what kinds are available for winter, spring, and summer spraying. We may add that the preparations about to be mentioned may be obtained from any nurseryman, or seedisman, or dealer in garden sundries.

\section{A.-WINTER SPRAY FLUIDS.}

These are suitable for application any time between November and March, when growth is dormant.

Cooper's V1 Fluid.-One gallon of this has to be diluted with cold water to make 100 gallons. A remedy for American Blight, Scale insects, Apple Pyslla, and insects generally or their ova; also for destroying lichen and moss. Non-poisonous. 
Sodalin (Ntrawson's).-An antiseptic wash for cleansing dormant fruit trees, roses, etc., and destroying lichen, American Blight, moss, Apple Weevils, and hibernating insects generally. Dissolve $1 \frac{1}{2} \mathrm{lb}$. in every ten gallons of watel used. Must not be allowed to touch the flesh of operator. May be used as a fumgicide. Add 1lb. of sulphate of copper to every ten gallons of above solution.

\section{The Woburn Wash Emulsion (Voss's). - I pre-} paration invented by Mr. Spencer Pickering, F.R.S. (I)irector of the Woburn Experimental Fruit Farm). Used for cleausing trees from moss and lichen, and destroying American Blight, Mussel Scale, Caterpillan, insect ova, ete. With each gallon of the emulsion 2ylb. of canstic soda is supplied. The latter has to be dissolved in nine gallons of rain water, and one gallon of the emulsion has then to be added to make ten gallonis.

Paraffin-Soft Soap Emulsion (Voss's).-Another of Mr. Spencer Pickering's preparations. Dissolve in 12 gallons of rain water $2 \frac{1}{2} \mathrm{lb}$. of canstic sorla, then add one gallon of the emulsion. Used for a similar purpose to the Wolum Wash.

Fruit Tree Wash (MacDougall's). - I wash specially prepared for spring and summer use, and only requiring to be mixed with cold water for application. The same makers also prepare a winter wash for use when the trees are dormant. Both are excellent and extensively used.

Anti-Fungoid Winter spray (Voss's). - I remedy for destroying the exposed hibernating mycelium of such fungi as Canker, Leaf Scorch, American Mikiew, Apple and Pear Scab, Brown Rot, Apple Mildew, and Currant Leaf Spot. One gallon to be diluted with 50 gallons of water. Poisonous. 


\section{B.-SUMMER SPRAY FLUIDS.}

V 2 Fluid (Cooper's). - A remedy for the active forms of Aphis, Psylla, Scale insects, and Caterpillars. Dilute one gallon of the fluid with cold water to make 100 gallons. Non-poisonous. V2K Fluid, made by the same manufacturers, is a suitable fungicise for destroying milkews.

Woburn Tobacco Extract (Voss's). - A preparation invented by Mr. Spencer Pickering, F.R.S., as a remedy for the Apple Sucker (Psylla), Green and Black Fly, Cuckoo Spit, American Blight, Thrips, Caterpillars, etc. Dilute one part with 100 parts of water (1lb. in 10 gallons) for general purposes; one in 50 for American Blight. Poisonous.

Woburn Bordeaux Paste (V'oss's). - A patent mixture invented by Mr. Spencer Pickering, F.R.S., and a suitable remedy for the Potato Disease, Apple and Pear Scab, Brown Rot, Peach Leaf Curl, rusts, and fungoid diseases generally. Porsesses a great advantage over the ordinary Bordeaux Mixture in being easy to prepare, of more uniform strength, and more efficacious in action. Used in varying strengths according to the crop and disease.

Woburn Bordeaux Emulsion (Voss's). - A combined fungicide and insecticide for spraying roses and fruit trees infested with Mildew, Caterpillars, and pests generally. One gallon to be added to nine of water.

Woburn Iron Emulsion (Voss's).-A cheap insecticide for destroying Aphirles and Caterpillars on roses and fruit trees. One gallon to be added to 20 to 30 gallons of water. 
Cariton Arsenate of Lead Paste (Voss's). - A preparation for destroying the larve of the Codlin, Winter, March, Ermine, Lacliey, Gooseberry, and other Moths. For the Codlin Moth larve apply directly the petals have fallen. Must not be applied within six weeks of picking the fruit. Use at the rate of $11 \mathrm{~b}$. to 25 gallons of water. T'oisonous.

Cyllin Soft Soap (Jeyes').--An excellent remedy for Mildew, Greenfly, Caterpillars, American Blight, Red Spider, Black Currant Mite, etc. Dissolve one part in two parts of hot water, and add cold water to make one gallon. For Gooneberry Mildew and American Blight add a teaspoonful of fine $\mathrm{Cy}$ llin to each gallon of solution. Non-poisonous.

Abol (White's Superior) Insecticide.-One of the best spray-fluids for general use in the garden or greenhouse. Requires to be applied by means of a special sprayer, called the "Abol Patent Syringe," which is fitted with a patent nozzle, to enable various forms of spray to be produced. Use one measure of the liquid to one gallon of water. Non-poisonous.

\section{C.-MISCELLANEOUS INSECTICIDES.}

Clubicide (Cross's).-A preparation used largely by market growers for preventing disease and destroying eelworms, millepedes, slugs, and other soil pests. It may be used at the rate of $10 z$. to 12 gallons, or one pint to 2:) gallons of water for watering growing crops. Apply once a week.

Niquas (Corry's).-A non-poisonous preparation suitable for indoor or outdoor use. A good remedy for GreenHy, Thrips, Scale, Mealy Bug, Red Spider, etc. One pint to twelve gallons of water for ordinary use.

slugene (Stanley's). - An excellent remedly for exterminating slugs and suails in gardens, greenhouses, or 
frames. Is far more efficacious than lime or soot, and does no harm to the crops.

Gishurst Compound (Price's). - An old and excellent preparation for destroying Greenfly, Mealy Bug, Scale, etc. Good for cleaning vines in winter.

\section{"XL-All", Nicotine Liquid Insecticide} (Richards'). - A well-linown remedy for Greenfly, Mealy Bug, and scale insects.

Apterite (Cooper's).-A soil fumigant, which, when dug into the soil, diffuses dearlly fumes upwards and downwards, and kills Wireworms, Leather Jackets, Woodlice, Ants, Millepeders, and Slugs.

Kilogrub (Peak and Co.).--Another soil fumigant, having a similar action and effect to the previously-named preparation.

Vaporite (Strawson's). - A soil fumigant, the first of its kind to be introduced. Has a similar action and effect to the preceding remedies.

" Naptho-Nicotyl" (Voss's). - A preparation for destroying Grubs, Beetles, Slugs, Eelworms, etc., in the soil. Use at the rate of $1 \frac{1}{2} \mathrm{oz}$. per square yard, digging same deeply into the soil in winter.

"Carbo-Nicotyl" (Voss's). - A preparation for sterilising the soil in which tomatoes previously infested with Eelworm have been grown; also for application to composts intended for tomato culture under glass as a preventive of Eelworm and fungoid attack. Use half a pint to three gallons of water, pouring the "Nicotyl" into the water, and stirring the whole freely. Above quantity sufficient for fourteen square yards. Apply with a water-can, then give three good waterings to wash the 
solution into the soil. A week or so afterwards the plants may be put in. "Creo-Nicotyl" is a similar prepalation, but stronger, and requires to be applied a month hefore planting.

Jeyes' Fluid. - An application of this germicisle at the rate of one ounce to a gallon of rain water to soils or composts infected with fungoid germs or Eelworms a week before planting will prove an efficient steriliser.

\section{FUMIGANTS.}

"XL-AII" Fumigator (Richards'). - A liquid nicotine preparation, the fumes of which are vaporised by means of a special lamp. Sold in quantities to suit the cubical contents of the greenhouse to be fumigated.

Lethorion Vapour Cone (Corry's). - A metal cone made in sizes to suit the cubical area of various greenhouses, and containing a special nicotine preparation which is vaporised by means of a candle placed under the cone.

Fumigen (Strawson's). - A preparation supplied in cone form to suit structures with various cubical contents. Requires no lamp or candle. Has simply to be lighted at the apex of the cone.

\section{Insecticide Sheets and Fumers (MacDou-} gall's).- The former consists of sheets of cellulose chargerl with nicotine, and made in sizes to suit houscs of different cubical capacities. The latter consists of a solid mass of nicotine, which has to be evaporated by lighting a small cantle placed beneath. 


\section{CHAPTER VI. \\ SPRAYING APPARATUS.}

To be able to use the insecticides and fungicides recommended in this rolume to the berst advantage the gardener must provide himself with an efficient apparatus. The old-time method of using an ordinary garden syringe or engine for the purpose no longer obtains, for science and experience have clearly demonstrated that if insecticides or fungicides are to act effectually they must be applied in a finely-diffused form-a very fine mist or spray-so that every particle of leaf, or branch, or bud is thoroughly moistened. This effect cannot be obtained by means of any ordinary coarse-nozzled syringe. Besides, there it a great waste of liquid, and, where costly fluids are used, the application of insecticides or fungicides is under such conditions a costly business.

Nowadays a variety of apparatus specially designed to apply liquids in an economical, effectual way may be obtained in sizes adapted for spraying on a large or small scale, and those who wish to use insecticides or fungicides to the best advantage should certainly make it their businoss to acquire a suitable one.

Large Spraying Machines.-Here we will deal with machines adapted for use in small orchards or gardens where standard trees require to be sprayed, and such as can be operated by one or two men.

Several machines of this type are manufactured by Messrs. W. Weeks and Sons, Ltd., Maidstone. They have a portable two-manual sprayer, operated by two men, fitted with strong pumps and unchokeable ralves, and mounted on a three-wheeled carriage. The pump posisesses sufficient power to deliver liquids through a hose for 200 to 300 yards away, and then to supply four to eight nozzles. Such a machine is useful where the pump cannot be brought close to the tree to be operated upon. 
The same firm nialie portable hand-power spraying machines, consisting of tanks mounted on two wheels, and capable of holding from 25 to 100 gallons of liquid. The pumps are of summetal, the valves of special make, and each machine has a large air chamber, which maintains a high pressure between each stroke of the pump. Each machine has a suitable length of delivery hose fitted

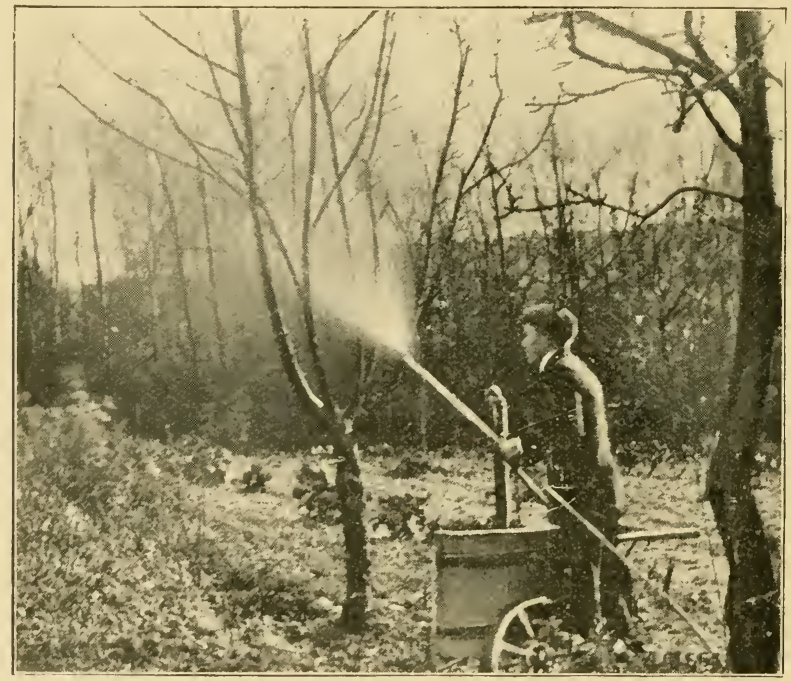

WINTER SPRAYING FRUIT TREES.

with bamboo or brass attachments, and two sets of nozzles. These machines are suitable for half-standards or bush trees, and handy for gardens or small plantations. They were awarded hoth first prizes for power and hand sprayers at the Royal Agricultural Show at Gloucester, 1909, and also gained first and second prizes for power, and first and second prizes "lfor hand sprayers, at the Bath and Wrest of England Show at liochester, 1910. 
The "Strawson" sprayers, manufactured by Mackies, Ltd., Reading, are also excellent hand-power machines. One is the "Portable Fruit Tree Sprayer," a light machine, not mounted on wheels, but provided with four handles to enable it to be easily moved about by two men. A powerful brass pump is fitted to a horizontal 18-gallon barrel, mounted on an iron frame, and two $30 \mathrm{ft}$. lengths of delivery hose, fitted with brass lances, cocks, and nozzles. This machine is capable of delivering the spray to tall standards. They also make a smaller machine, to run on four small wheels to be drawn by hand or a pony. This is known as the "Small Fruit Tree Sprayer."

Knapsack Sprayers.-Here we have a type of machine that will suit the requirements of owners of small gardens. They are made in various forms, but all are constructed so as to be carried on the back, one hand operating the pump and the other the delivery hose.

Messrs. W. Weeks, Ltd., Maidstone, make what they term an "Improved Knapsack Sprayer," capable of holding $3 \frac{1}{2}$ gallons of fluid, and weighing when full $14 \mathrm{lb}$. It is strongly made, is very durable, and reasonable in corst.

Messrs. Ph. Mayfarth and Co., Bunhill Row, London, E.C., have a knapsack sprayer called the "Syphonia," which automatically delivers the fluid without the aid of a pump. It consists of two parts-the tank, or sprayer, and a force pump. The latter has to be fixed to a tub containing the fluid, and is then connected to the tank when to be filled. First of all air is pumped in until the pressure gauge registers $15 \mathrm{lb}$. pressure, then the fluid is pumped in until the gauge indicates $45 \mathrm{lb}$., when the tap is turned off and the delivery hose adjusted. When required for use it is only necessary to turn the tap slightly to deliver the spray with great force. Can be used by a man or youth.

The Alpha Extinguisher, Ltd., Ross, Herefordshire, also make a handy and efficient machine, known as the 
"Alpha Knapsack Sprayer." It is in the form of a cylindrical tank, fitted with straps to enable it to be carried on the back of a man. It is made in sizes to hold one quart, two quarts, three quarts, one and a half gallons, three and a half gallons, and five gallons, and is automatic in action, the fluid being discharged by compressed air forced in prior to charging by means of an ordinary bicycle pump. An excellent machine for orchard, garden, or greenhouse spraying.

Vermorel's Knapsack Sprayer ("Ectair No. 1") is a well-known machine, which has been extensively used in this country for many years. It is of handy size, durable, and reasonable in cost. The liquid in this case is discharged by working a pump lever with one hand, while the other is employed in directing the spray on to the trees. The sole agents are Messis. Cooper, Prgler, and ('o., 24 to 26 , Christopher Street, Finsbury Square. Jondon, E.C.

A cheaper but equally effective machine is made by Jeyes' Sanitary Compound Company, Ltd., Camnon Street, Jondon, F.C. This consists of a galvanised iron tank, capable of holding two gallons of liquid, and weighing when full 20lb. Attached to the tank is a delivery hose comnected to a svringe fitted with a brass arm about $3 \mathrm{ft}$. or so long, terminating in a fine nozzle. The operator holds the body of the syringe in the left hand, and with the right draws out the piston to charge the syringe with liquid; then gently, but firmly, pushes it forward to force the liquid out in a fine spray on to the tree or bush. This machine is easy to work, and does its work most effectively.

Handy sprayers. - This form of apparatus is one that can be carried in the hand and worked by compressed air, or by an indiarubber tube and air-ball. There are many kinds of these, varying from the type used by hairdressers to larger sizes made in brass or other metal. Those worked by compresised air are very handy to use. 
The liquid is placed into a reservoir and this screwed down tightly; then a cylinder is filled with compressed air by rneans of a small hand-pump attached. When required for use it is only necessary to turn on a tap and the liquid will be forced out in a steady, fine mist or spray. This is called a " pneumatic sprayer." Other kinds have an air-pump attached, which has to be steadily worked to diffuse the liquid; and others have a brass tube and indiarubber ball attached, with a tube fitting into a bottle, the liquid being forced out by pressure of the ball. These small hand-sprayers are suitable for spraying plants in pots, or rose bushes.

Syringes. - Ordinary syringes fitted with fine nozzles may be used for applying soft soap and quassia solutions to rose bushes or plants, but not for the application of fungicides or insecticides that have to be applied in a very fine spray. The best types of the ordinary syringe are undoubtedly Reid's Patent, fitted with Cooper's Protector and Stone's Plunger; and Cooper's Patent, fitterl with duplex spray-jets and protector. For the application of insecticides generally on a small scale the "Abol Sprayer" is unquestionably the best of the syringe type. This is fitted with a curved nozzle and very fine sprayer, which enables the liquid to be easily applied to the under, as well as the upper, sides of the foliage by turning the nozzle in the direction required. Moreover, it has the merit of not being expensive.

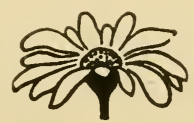




\section{CHAPTER VII. \\ POWDER DISTRIBUTORS.}

Iт is necessary to be equipped with a suitable apparatus to apply the various insect powders recommended elsewhere in this volume. It is true, many powders are supplied in tins with perforated lids to enable them to be dredged on to the leaves. This, however, is a clumsy method. What is wanted is an apparatus that will distribute the powder evenly and gently over the entire surface of the leaves, and this can only be properly done by one of the following apparatus:

Indiarubber Distributors.-. These are made of stout indiarubber, with a brass nozzle attached. The powder-tobacco, hellobore, or sulphur-is placed inside, and by pressing the indiarubber bag in the hand the powder is forcerd out through the nozzle. The "Acme" is the best form.

Sulphurators. -There are several kinds of these. A simple form is the "Midget," which consists of a small bellows with a spout terminating in the form of a spoon. The sulphur, by pressing the bellows in the hand, is driven out in a fine cloud.

Another kind is of French origin, and consists of a bellows, with a vesisel attached for holding the sulphur, and a spout with a spoon-like end. The bellows is worked with two hands, and the sulphur driven out in a wide and long spray. A useful apparatus for sulphuring rose trees, rincts, etc.

The distributors and sulphurator's are inexpensive and indispensable apparatus for applying powder insecticides. 


\section{CHAPTER VIII.}

\section{HOW AND WHEN TO SPRAY.}

Although the precise time to spray for any particular insect or disease has been given in the remarks under each, yet it will be well, perhaps, that we should supply a few general hints on the subject, and on other matters pertaining thereto.

When to Spray.-Generally speaking, winter spraying is done when growth is dormant. January to March is about as good a time as any for carrying out such work. Spring spraying is usually done between March and May. Summer spraying may be done any time during the season of growth.

Poisonous spray-tluids should not, however, be applied to ripe or ripening fruit. It is really not safe to spray within six weeks of the fruit being fit to eat. This rule should be strictly observed in order to avoid fatal accidents.

Spraying, again, should be done in fine weather, not when raining, otherwise the fluid will be washed off before it has had time to take effect. Evening is a good time to spray on a small scale.

How to Spray. - See that the mixtures or fluids are thoroughly well mixed before using. Where coarse materials enter the composition of the fluids it is advisable to strain the liquids through a fine strainer before using; otherwise grit or other particles may get into the spray nozzles and prevent the efficient working of the apparatus.

Whether applied with a spraying machine or with a syringe, always see that the liquid is delivered in a mist- 
like diffusion, so that it effectually coats the upper and under sides of the leaves with a thin film of moisture. Mixtures like Paris Green always injure the foliage if the liquid collects in drops on the edges of the leaves.

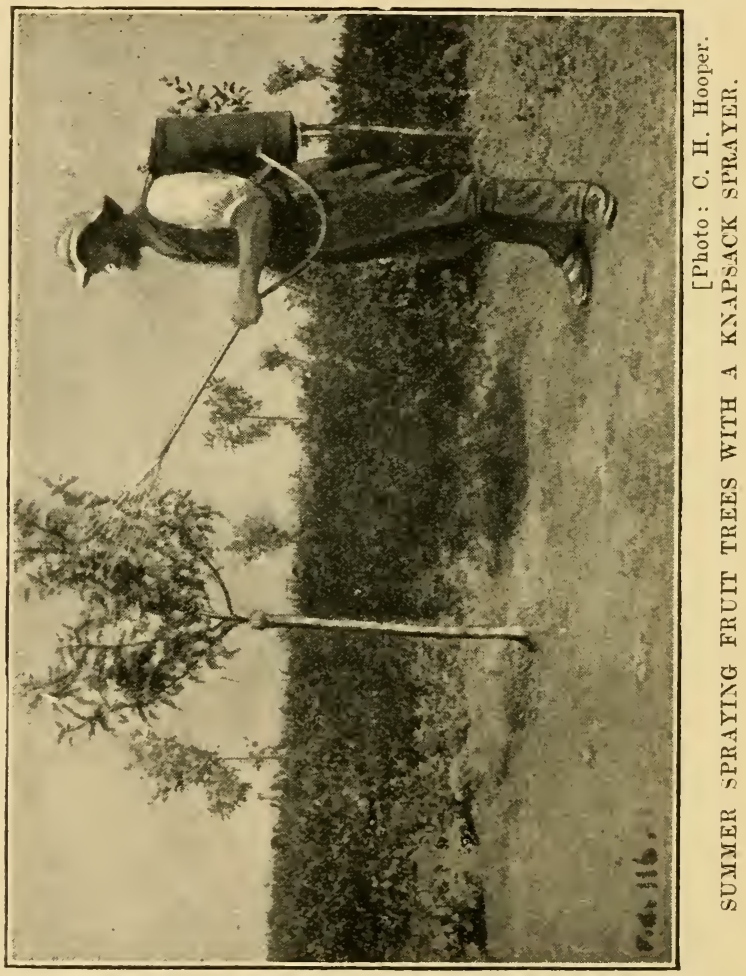

Poisonous fungicides or insecticides must not be applied to trees having saladings or vegetable crops, or fruiting strawberries beneath. These will discolour the foliage and render the crops unsafe to eat. In the case of spraying trees in orchards do not allow live stock or poultry to 
enter until several weeks after the spraying is done, or serious consequences may follow.

A coarser spray should be used for winter than for summer work. In winter spraying see that the fluid is forced into every crevice of the bark, and also reaches every twig and branch. Always use indiarubber gloves cn the hands when spraying with the caustic soda emulsion. If not, the skin may be burned by the fluid.

\section{Syringing Grèenhouse or Window Plants.-}

Very large plants should be laid on their sides and the foliage be gradually well moistened by the fluid, the operator standing at the pot end and turning the plant over by degrees. Keep the plant on its side for an hour or so, then well syringe with water. Smaller plants may be syringed thus: Place the insecticide in a large tub; then get another person to hold the stem and pot firmly on the edge, while another well syringes the foliage, which is held over the liquid. Small single plants may be treated as follows: Grasp the stem between the middle fingers of the right hand and also the top of the pot. With the other hand also hold the pot firmly; then invert the foliage and dip it two or three times in a vessel of insecticide, and give it a gentle shake to disperse superfluous fluid.

A number of small plants may be treated quickly in this fashion. This is a good way to cleanse fern fronds of dust.

sponging Plants.-Many hard-leaved plants, like oranges, camellias, etc., may be cleared of insects by sponging the leaves and stems with an insecticide solution, such as soft soap and quassia, or paraffin and soft soap, or one of the advertised insecticides. Use a piece of sponge free from grit. This is very important, as particles of grit would lacerate the leaves. Scale insects may be scraped off with a thin blade of wood or removed with a hard tooth-or nail-brush, and the parts afterwards well washed with the sponge and insecticide. Frequent sponging is beneficial, as it not only removes insects, but also honeydew and filth collected on the foliage. 


\section{CHAPTER IX.}

\section{FUMIGATING.}

Is addition to the method of fumigation by the cyanide process, described in the next chapter, there is also the old-fashioned one of fumigation by means of the many nicotine preparations in the market. It is a ready means of eradicating such pests as Thrips, Aphides (Greenfly), Red Spider, Snowy Flies, etc., from glasshouses, including frames. Formerly fumigation was attended with a certain amount of risk to the plants, since the materials available could not be depended upon for their purity and freedom from injury to vegetation. Of late years, however, several preparations of nicotine have been placed on the market that are absolutely safe to use if employed in the manner directed by the makers, and at the same time far more effective in the destruction of indoor peists.

Materials. - The old-fashioned linds were shag tobaceo and paper, or rag steeped in tobacco juice and then dried. These materials, when required for use, had to be placed in a vessel containing hot coals, and allowed to burn slowly so as to fill the house with a dense volume of smoke. As there was always a risk of the materials blazing it was necessary for the attendant to have to watch the combustion, and to go inside, breathing the fumes meanwhile, and damp the materials, thus meeting with personal discomfort.

This antiquated method, however, no longer obtains in well-ordered gardens. By means of the specially-prepared sheets or rolls saturated with nicotine, or the compounds of nicotine prepared in liquid or solid form and sold in sizes or quantities to fumigate according to the cubical 
area of a greenhouse or frame, it is possible to fumigate glasshouses without the slightest personal discomfort or risk of injury to vegetation, and with the absolute certainty that all pests will be destroyed. The sheets or rolls have simply to be fixed in the house and ignited, and left to burn by themselves without any necessity to re-enter the house.

The other preparations have to be vaporised by means of a small spirit lamp placed underneath. Each invention is sold complete, so that it is umnecessary to purchase

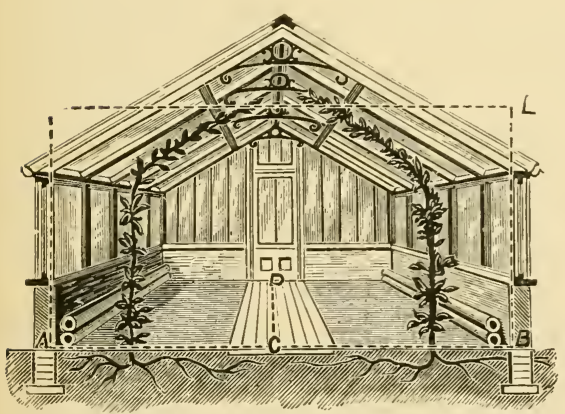

Fig. 1.

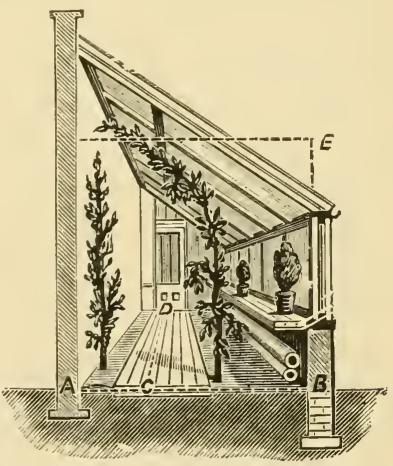

FIt: 2.

CUBICAL CONTENTS OF GREENHOUSEDiagrams showing above are to be obtained.

a fumigating apparatus. There are a number of these excellent materials in the market-such as cones charged with nicotine, and which have simply to be ignited, no lamp being required-and it would be invidious on our part to mention any of them specially. No doubt, several will be advertised in this volume. If not, a reference to the pages of "Amateur Gardening " or the "Gardeners" Magazine" will give a choice of suitable preparations.

Cubical Capacity of Greenhouses.-In order to use the preparations sold with accuracy, the cubical 
contents of the glasshouse should be ascertained beforehand, and either marked up in a spot easily to be found or memoranda thereof entered in a notebook. Most of the nicotine preparations have printed directions on them stating the quantity to be used per 1,000 cubic feet; hence it is essential the exact cubical area of a house to be fumigated should be known. To ascertain the cubical contents of a span or lean-to greenhouse, in order to know the exact quantity of fumigating material required, proceed as follows: In the case of a span-roof greenhouse (Fig. 1) multiply the length $\mathrm{C}$ to $\mathrm{D}$ by the breadth $\mathrm{A}$ to $\mathrm{B}$, and the total by the average height, obtained by the average height $\mathrm{B}$ to $\mathrm{E}$, and the result will give the cubical contents. Proceed in a similar manner with a lean-to structure (Fig. 2)-that is, multiply the length $\mathrm{C}$ to $\mathrm{D}$ by the breadth $A$ to $B$, and the total by the average height $\mathrm{B}$ to $\mathrm{E}$. The dotted lines show the directions in which the measurements should be taken. The portions of the roofs above the dotted lines $\mathrm{E} \mathrm{E}$ are allowed for by assuming that the angles of the dotted lines $\mathrm{E}$ to $\mathrm{B}$ represent space equal to these.

How to Fumigate.-The best time to fumigate a greenhouse or frame is the evening of a calm day. If the day be windy the rush of air through the laps of the glass or ill-fitting sashes, doors, and ventilators, will drive out the fumes, and the volume of nicotine fumes or vapour will not be sufficiently intense to destroy insect life. Failing a calm evening, choose the early morning of a dull day. In any case, see that the ventilators are tightly closed, and broken glass and crevices sealed up. Damp sacks or mats thrown over broken glass or badly-fitting ventilators, and also placed at the bottoms of the doons, will prevent the fumes or vapour escaping. The foliage, too, of the plants must be dry, and so must the floor and staging, for the nicotine to act effectively.

Once the materials are started into action, withdraw from the house and lock it up. If fumigated in the even- 
ing do not enter the house till the following morning, and if done in the morning wait till the afternoon before doing so. Remember, the fumes or vapour of nicotine are poisonous, and must not be inhaled.

In the case of aphides one fumigation usually kills them. Thrips sometimes require to be fumigated on two successive days, and Red Spider and Mealy Bug on three successive days. On the morning after each fumigation thoroughly syringe the plants to remove remains of dead insects.

Errors to Avoid.-Never fumigate ferns; their foliage is too tender to withstand the fumes, and will turn brown and shrivel if fumigated.

Fumigation, too, discolours the flowers of many plants, and causes them to shed their petals quickly; so avoid fumigating flowering plants in blossom unless badly infested.

Grape-vines, again, should not be fumigated when the crop is ripening; nor, indeed, should ripening fruit of any kind be fumigated, as there would be a risk of a poisonous deposit taking place on the skins.

Never exceed the quantity of materials ardvised for a specific number of cubic feet. It is far safer to err on the side of using a less amount and fumigating on two occasions than to exceed the amount in one operation.

Fumigating Outdoor Crops. - It is possible to fumigate fruit trees and bushes in the open air by enveloping the tree in a close-textured sheet and using tobaceo sheets or rolls, or one of the other compounds, at the base. The cubical contents of the area of the tree or bush should be ascertained, so as to use approximately the right quantity of nicotine. We have successfully fumigated wall trees, roses, larger fruit trees, and currant bushes in the manner just described. 


\section{CHAPTER X. \\ CYANIDING.}

\section{A NEW PRDCESS FOR DESTROYING INSECTS.}

A NEw method of dealing with insect and fungoid destruction on a large scale has been undergoing a practical test for some time, and the results obtained have been fairly satisfactory. The process, however, is one which requires to be carried out with considerable skill, since the chemi-

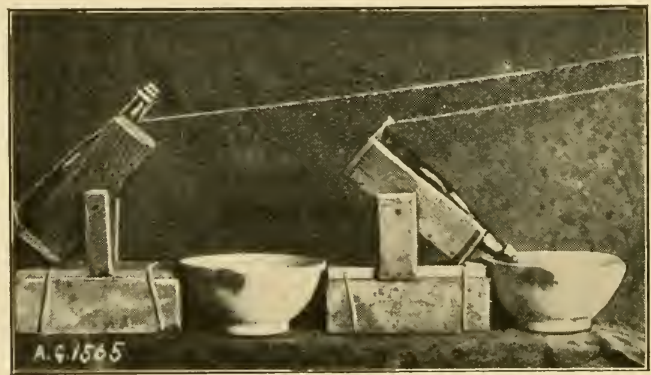

A.

B.

[Photo: J. G. Blakey.

A SIMPLE OTANIDING APPARATUS.

A shows the apparatus ready for use, and B the bottle tilted by pulling a otring so that the acid can fall on the cyanide in the vessel.

cals used are of a deadly poisonous nature. As this Handbook would not be complete without some reference to the subject, we reproduce the subjoined ably-written article contributed by Mr. W. M. Bear to the pages of "Farm and Garden."

"No reference to insecticides would be complete at the present time without mention of the process of cyaniding, 


\section{CYANIDING.}

by which every pest can be killed more surely than by any other method. Red Spider even has been said by some ust:r's to succumb to its effects, but it is still a question to many if this arlamantine pest can really be successfully treated on tender subjects, such as rines. A rery strong application, sufficient to kill Mealy Bug, can be made while the vines are dormant; but at this time the Red Spider is also dormant, and exceedingly hard to kill, beirg well hidden in cracks in the woodwork and under the bark of the rines.

"On growing plants great care is necessary in the application of the remedy. The teniperature of the houses must be as low as 50 degrees, and the plants dry and free from drops of moisture on the leaves. The evening is the best time, as strong light is not desirable during the operation. The rentilators of the louses to be operated upon must be capable of being opened from outside, as the gas is a most deadly poison. Nobody must on any account enter the house whilst the fumigation is going on. It is most important that all chemicals used in the preparation of the gas shall be of known strength, and be obtained from reliable firms.

"The Chemicals Used are a double salt of potassium and sodium cyanide, 98 to 100 per cent. purity, and sulphuric acid of specific gravity 1.8. The former chemical is often called sodium cyanide 130 per cent. This has been used to denote the fact that the strength of the above-mentioned double salt, as compared with potassium cyanide of 98 per cent. purity, is as 130 to 100 . That is, if $1 \mathrm{oz}$. of potassium cyanide 98 per cent. would be required to fumigate a certain space, only ${ }_{4}^{3} \mathrm{oz}$. of the 130 per cent. sodium cyanide would be required to do the same work. Now potassium cyanide is made in strengths varying from 30 per cent. to 98 per cent., so that unless the exact strength is known, and the quantity required calculated on this basis, serious damage might be done to the plants. On the other hand, this double salt of sodium and potas- 
sium cyanide is only marle in the one strength, so that when the grower sees the results of experiments published in which so much sodium cyanide was used without hurting the plants operated upon, he need not hesitate to use the same weight of chemical; but if he sees that potassium cyanile was used he must first find out what strength was used before repeating the operation for himself. All he must remember is that sodium cyanide 130 per cent. is the same thing as sorlium-potassium cyanide 98 to 100 per cent. purity. It is a pity that the former term was ever allowed to exist at all. It is absurd and inaccurate, and should never have been allowed to pass by the introducer of it as a horticultural chemical. It is true he explains the incongruity of the term 130 per cent., but he does not say that it is a double salt of sorlium and potassium.

"How it is Done.-To come to the actual operation of cyaniding, first estimate the space in cubic feet to be operated upon. Then to every 2,000 cubic feet allow for a first experimental application $\frac{3}{4} \mathrm{oz}$. of 98 per cent. sadium-potassium cyanide, and $1 \frac{1}{2}$ fluid ounces of sulphuric acid 1.8 per cent. specific gravity. The acid, before using, must be diluted by pouring it slowly into two and a half times its bulk of cold water. For a small greenhouse of, say, 4,000 cubic feet, where only two sets of apparatus would be required, proceedings may be taken as follows: Obtain iwo glazed earthenware pans. Into these put the diluted sulphurice acirl. Above the pans hang a piece of board, which can be swung to and fro like a punkah by means of a string pulled from outside. Wrap the dose of cyanide in a small piece of llotting-paper or muslin, and, if possible, suspend it just over the pan by a cotton, which can be cut from outside. If this cannot be done, the packet must be dropped into the acid by hand, and a rapid retreat be made at once. Do not use much wrapping for the cyanide, $n r$ it may float on the acid, and no action talie place for 
a long time. Keep the houses shut for forty minutes, and keep the punkahs swinging for thirty minutes to distribute the gas thoroughly. At the expiration of the time throw open all doors and later the ventilators, to allow the fumes to escape before anyone is allowed to work in the houses. If this mild dose is found insufficient to kill the insects on the plants, increase the dose $\frac{1}{2} \mathrm{Oz}$. at a time, with the corresponding quantity of acid, until the right strength is found.

“The Apparatus.--Anyone wishing to do cyaniding on a larger scale cannot do better than make himself the following apparatus, the invention of Mr. G. F. Strawson. One set of apparatus is required for every 2,000 cubic feet of air space to be cyanided. The illustration given herewith shows a complete set of apparatus ready to be set in

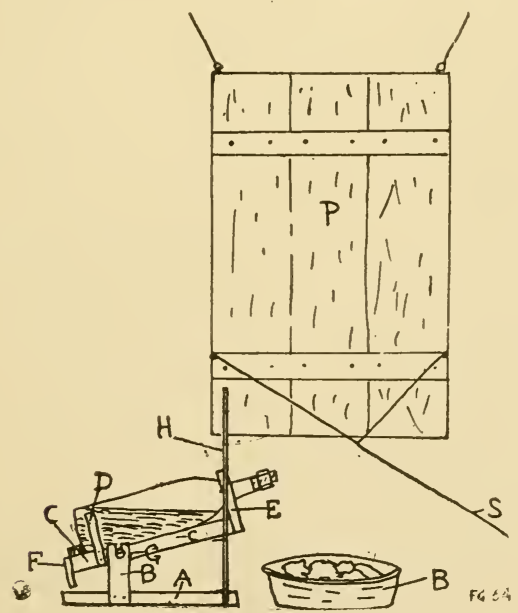

APTARATUS FOR CYANIDING.

action. The punkah, $\mathrm{P}$, is made of pieces of board nailed to cross battens, and is hung by strings from its top corners 
to screw-eyes in the rafters above, so as to hang evenly about 18in. from the ground. It may measure about $3 \mathrm{ft}$. by $18 \mathrm{in}$. A stout string, $\mathrm{S}$, is fixed to the punliah, much in the same way as the string to a kite, only horizontally, instead of vertically, and is led outside through a hole in the door. A cord taken from the back of the first punkah is fixed in the same way to the front of the next, and so on down the whole house, so that on pulling the cord outside all the punkahs are set swinging at the same time. A glazed earthenware pan is placed under the punkah, and the cyanide is put into it. Then the bottle containing the diluted acid is placed as shown in the sketch, supported by the strip of wood, $H$, which has a nail driven through it, which is placed under the platform, C, upon which the bottle lies. Now on pulling the string, S, the punkah is drawn forward and knocks away the supporting strip, H. This allows the bottle to drop down and empty its contents into the pan of cyanide. Action immediately takes place between the two chemicals, and the hydrocyanic acid gas is liberated, and is thoroughly distributed to every part of the house by swinging the punkahs.

"The Bottie Apparatus. - To give a detailed description of the bottle apparatus: The bottle, which is generally an old champagne bottle fitted with a cork having two triangular grooves cut in it on opposite sides, one of which allows the acid to run out slowly and the other for the entrance of air to take its place, rests on a piece of board $11 \mathrm{in}$. by $33 \mathrm{in}$. by $1 \frac{1}{4} \mathrm{in}$., marked $\mathrm{C}$. At the front (nnd of this is nailed a small piece of wood, F, having a notch cut in it to fit the neck of the bottle. A small strip of wood is nailed on to $\mathrm{C}$ behind the bottle to keep it from slipping backwards, and to keep it pressed up to the notch. Two small upright strips, D, are nailed one on each side to keep the bottle from rolling off. Two screws are put about halfway in, as at $\mathrm{G}$, for the platform, C, to swing on. These must be placed so that when the bottle is in the position shown in the sketch it will drop neck 
downwards immediately the trigger, $H$, is pulled away, and so that when the bottle is tipped over as far as it will go the other way it will remain in that position for filling, etc. A button, $F$, is put on of such a length that when it is turned down, as in the sketch, the bottle will not remain at rest, but must pitch forward and empty its contents. The screws, G, go into slots cut in the two uprights, B, which are nailed to a piece of board, A. The trigger, $\mathrm{H}$, is simply a small strip of wood long enough to reach from the ground to the punkah, and having a nail driven through it to act as a support to the platform, $C$, when the apparatus is set.

"A Word of Caution.-There are a few remarks to be made about the process before concluding. Sulphuric acid, when diluted, must always be poured into the water, for if the water is poured into the acid it will probably be distributed about the operator's person in a way he is not likely to forget. When opening the ventilators to allow the gas to escape, keep to windward, and hold the breath until you are at a safe distance, and do not enter the houses until half an hour has passed. Remember that the temperature must be low and the leaves of the plants Ary, or damage will result. Experiment first with small doses, and gradually increase until the pests are killed. Mr. Strawson has foumd the following strengths efficacious: $1 \frac{1}{2} \mathrm{Oz}$. of the 130 per cent. cyanide per 2,000 cubic feet sufficient for easily-killed insects; and from 2oz. for some others, up to $3 \frac{1}{2} \mathrm{Oz}$. for Red Spider."

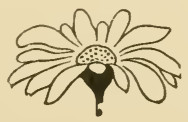




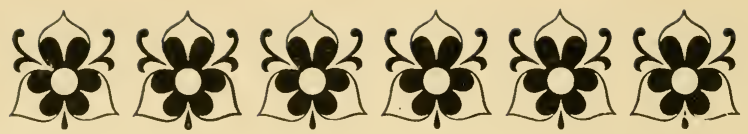

\section{Part II.-FRUIT FOES.}

\section{CIIAP'TER I.}

\section{APPLE PESTS.}

\section{A.-INSECTS.}

American Blight (Schizoneura lanigera). - This pest, also known as the Woolly Aphis, is not, as its popular name would imply, of American origin. It is really a European pest, which found its way to America and thence to this country. It belongs to the Aphis family, produces winged and wingless females, and, like other aphides, brings forth its young alive during spring and summer, eggs only being laid in autumn. The white cottony substance found in patches on the shoots, etc., of trees is an excretion from glands on the back of the female insects. The young aphides, or lice, are yellowish or reddish in colour. Successive generations of the latter are produced by wingless females from spring to aut $11 \mathrm{~m}$. Late in the year winged females and males appear, the former laying the egg, then dying. The eggs hatch in spring. A few viviparous females, however, hibernate in the bark or on the roots, come forth in spring, and give birth to fresh broods. The lice pieree the tender parts of the shoots with their beaks and extract the sap. The punctures cause abnormal development of the cells and 
excrescences to form on the shoots or branches. These growths interfere with the proper flow of the sap, and cause the tissues to be diseased. Trees badly attaclied, therefore, become unhealthy, and refuse to bear freely. The cotiony substance covering the lice gets blown by the wind or carried by the feet or feathers of birds to other and healthy trees, and, as small lice are invariably attached, new colonies are constantly being founded in "fresh fields and pastures new," so to speak. Moreover,

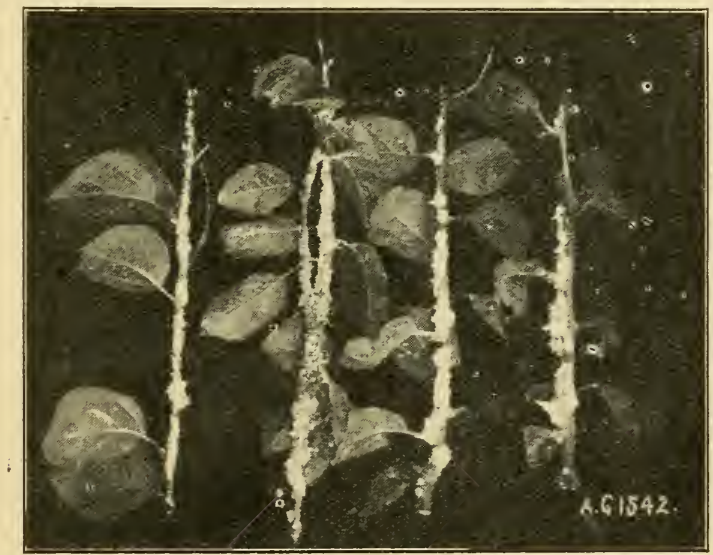

[Photo: J. G. Blakey.

APPLE SHOOTS INFESTED WITH AMERICAN BLIGHT.

colonies of this pest also live on the roots, and cause galls to form thereon.

liemedies. - Thoroughly spray the trees in winter (February) with Formulæ Nos. 1 or 8 . In March inject into the soil some carbon disulphide to destroy the winter brood of Aphides hibernating on the roots. Apply by means of a special syringe, pushing the nozzle of the latter six inches into the soil. Apply 2 to $40 z$. to each tree, and about $2 \mathrm{ft}$. from the trunk. The carbon is highly inflam- 
mable, so do not smolie when using it. In summer the best remerly is to paint the infested parts with paraffin oil.

Apple Aphides.-Several aphides attack the foliage of the apple. Thus the Leaf-curling Aphis (Aphis pomi) attacks the young leaves in early spring, causing them to curl. Then another species, the Rosy-leaf Aphis (Aphis sorbi), causes the leaves to assume a rosy-red tint and to

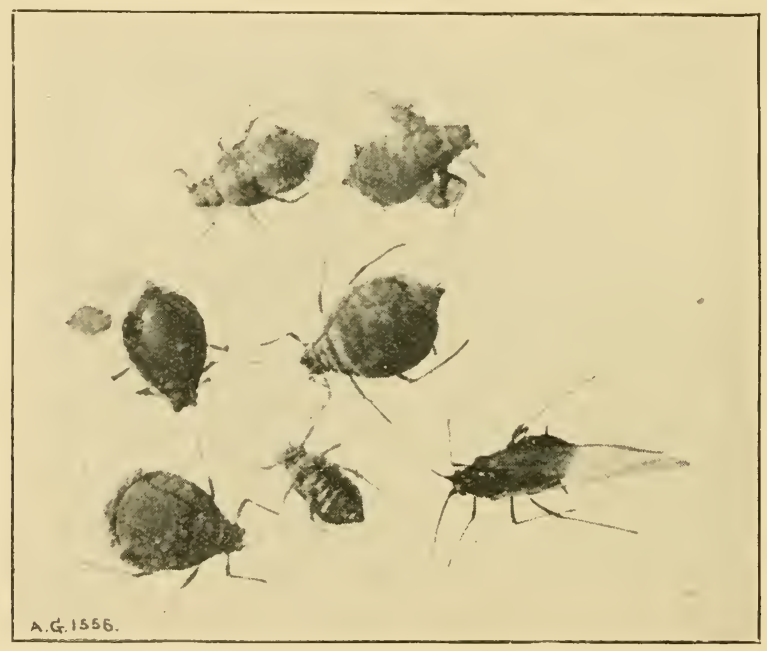

APPIE APHIS (APHIS POMI).

[Photo: J. G. Blakey.

showing the insects in variolls stages of development.

curl very much. Yet another-the Blossom and Leaf Aphis (Aphis fitchii) - feeds on the opening buds, and later the blossoms. In each case the insects are hatched in early spring from eggs laid the precedirg autumn.

Remedies.-Spray in autumn with the Winter Wash (Formula No. 5); or in February with Formula No. 1; or in April with Formula No. $16 . \quad$ See Chapter III., Part I. 
Apple Blossom Weevil (Anthonomus pomorum). The larvie of the Apple Blossom IVeevil do an immense amount of injury to the blossoms of apple and pear trees in spring. The weevil measures only one-quarter of an inch in length and one-eighth in breadth. It is usually of a blackish colour, covered with down of an ashy-grey hue. It is provided with a rostrum, or snout, about half as long as its body. The weevils hibernate in chinks and crevices of the bark of various trees during the winter. Directly warm spring weather sets in, about the end of March, the weevils find their way to the blossom buds of both apple

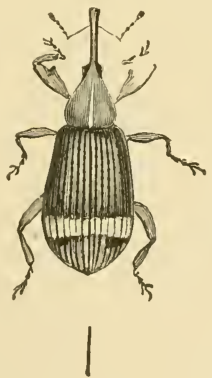

APPLE BLOSSOM WEEVIL (ANTHONOMUS POMORLM).

and pear trees. The female then deftly bores a hole with her snout in the flower-bud, and deposits an egg therein. The egg hatches in about six to nine days, producing a white maggot without feet, and about one-third of an inch long. The maggot lies in the bud and devours the stamens and pistil, causing the petals to wither and the bud generally to change to a rusty hue and decay. In the course of a fortnight the larva change into pupæ, in which state they remain from seven to ten days, then appear as perfect weevils, escaping through the hole bored in the bud by their parent. It is not known for certain whether the young weevils feed upon the foliage or not. 
Remenies.--(1) Undoubtedly the best remedy is to spray the limbs and branches of the trees in February with Formula Nos. 1 or 8 . This will serve the double purpose of destroying any lichens and mosses on the trunk and branches, and at the same time kill weevils or larvie of other pests hiding in the chinks or crevices of the bark. (2) ()r the trees may be sprayed in winter with Formula No. .).

Apple Sawfly (Hoplocampa testudinea). - This pest causes injury to the young fruit of apples in pretty much the same way as the Corlin Mcth grub. The Sarfly is about one-quarter of an inch long, and has a black, shiny body, with a reddish-yellow undersirle, and transparent wings. The sawflies appear about the same time as the apple blossoms begin to expand, and then the fenales deposit their eggs in the centre of the flowers. From these are hatched small pale maggots, which at once begin to feed on the centre of the embryo fruit. As the maggots increase in size, so they moult their skins, finally ap)earing a creamy colour, with a pale chestnut head, and measuring half an inch long. The maggot continues to feed on the interior of the apple until it drops; then it escapes and descends into the ground to enter into the pupal stage, in which it remains till the following May; then appearing as a sawfly, and commencing the plocess of egr-laying. The injuries done by the Apple sawfly magrot may be easily distinguished from those done by the Corilin Noth grub. The former do not inalie tumnels, but simply eat out a cavity in the centre of the fruit; whereas the latter form tumnels.

Riemenies.-(1) Needless to say, all fallen fruit should at once be collecterd and burnt. On no account throw the apples on to a heap, where there is a possibility of the larve forming pupae, and appearing next season as sawflies. (2) Spray the trees directly the apples are formed with Paris Green solution (No. 11) or Arsenate of Soda Wash (Formula No. 10). (3) If the trees are grown in 
cultivated orchards stir the ground well at the end of April and during May, just at the time the sawflies are emerging from their pupal state. Also spread quicklime liberally over the surface of the soil to aid in attaining a
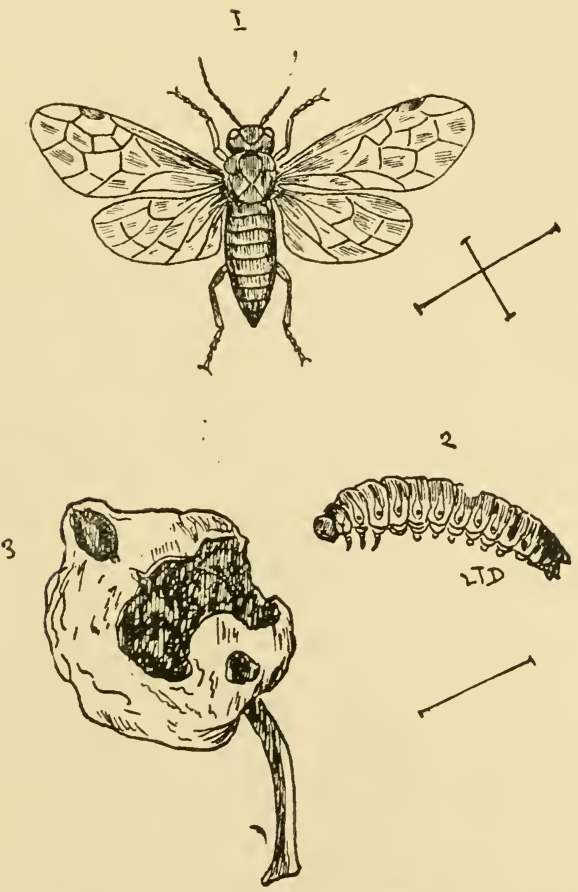

APPLE S.IWFLY GRIB (HOPLOCAMPA TESTIDINE.I).

To the right of the ection of an apple is the grub which has formed the cavity shown in the fruit. At the top io the sawfly with lines to show its natural size.

similar object. (4) Apply kainit at the rate of an ounce per square yard to the soil in autumn, and fork it in. (5) Dig in one of the soil fumigants in autumn to destroy the pupie. 
Apple sucker (I'sylla mali).-This is an insect which has of late years done a good deal of injury to fruit trees. Being rather small, however, and not exceeding oneeighth of an inch in length, its presence is often not discovered; and, moreover, the injuries it causes to the fruit and wood buds is often attributed to other pestis or causes. The perfect insect appears in May and June, and is of a yellow, greenish, or reddish colour, with transparent wings. Both the male and female may be seen on the

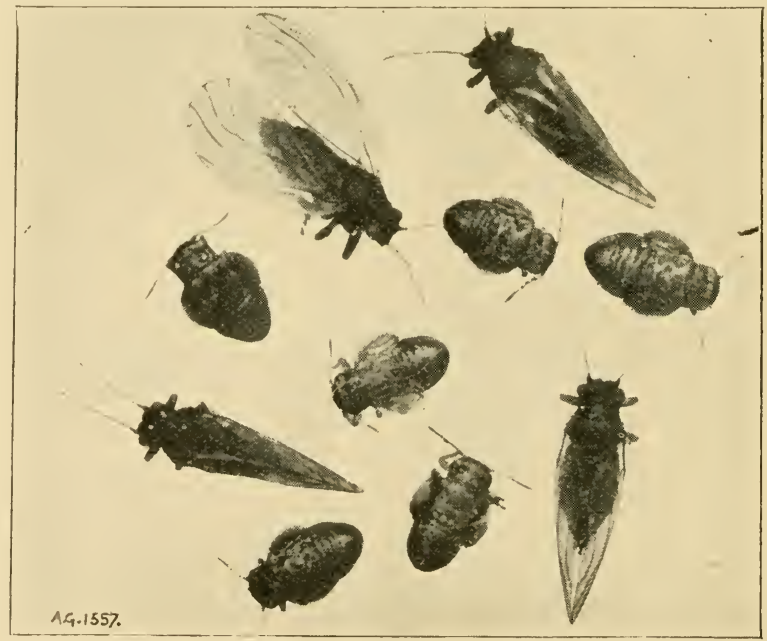

['hoto: J. U. Blakey.

APPLE SLCKER (ISYLLA MALI) AND LARTE.

These insects are magnified six diameters.

leaves of apple trees in September-the pairing period. The female begins egg-laying about then, and continues doing so up to November. She deposits the eggs singly on the young shoots and on the older branches. They are white or pale yellow, spindle-shaped, and have a thread-like appendage at one end. Hatching takes place 
in spring, after which the tiny larvie emigrate to the nearest fruit buds, and at once begin to suck out the sap. In a short time each infested bud becomes charged with "honey dew" and excreta, the growth of the blossom is arrested, and the latter shrivels and falls off. The flat yellow-and-brown-spotted larve go through three moults. After the first moult globules with hairs attached form on its body. After the second one the skin becomes green and clothed with white hairs. At the third moult rudimentary wings are formed. Finally, the larva pupates in a few hours, and comes forth as a perfect insect. It is the larve which does the injury. So far as is known the perfect insect is harmless.

Remedies.-(1) Spray the trees thoroughly with the Lime-salt Wash (No. 9) in February or early March. Spray again in September with a Kerosene Emulsion (No. 16).

Apple Tree Mite (Oribata lapidaria). - This has been found to do considerable damage to apple trees by congregating at the base of fruit buds and sucking out the sap. As a consequence, the young fruit withers and refuses to develop. The mites are exceedingly small. The adults lay their eggs in crevices of the bark, and from these are hatched tiny larvæ, which go through a succession of three moults before attaining maturity.

Renedies. - Spray in summer with a Soft Soap and Kerosene Ernulsion (No. 16), or with No. 1 Formula in Feb. ruary.

Brown-tail Moth (Euproctis chrysorrhea).-The larva of this moth dwell in communities under a web, or "tent" on the foliage of trees, and do considerable injury to the young leaves. The parent measures an inch and a-quarter to one-and-three-quarters in the spread of its wings. The forewings are white spotted with black; the hind ones pure white. The male has a golden-brown tail. The moths fly during the night only. The female lays her 
round, grolden-tinted eggs on the under sides of the leares, and covers them with fine hair. This occurs in July or August. The resultant larve are small and yellow dotted with black. They spin the leaves together, and feed on the epidermis only. In September they spin several leaves together and line them with silk, so as to form a "tent." In this way they live during the winter. In spring the larve wander over the branches, moult in May, changing to a brown colour first, marked with white spots and lines of red and black. Thenceforward they devour the leaves freely, finally spimning a cocoon amongst then, and entering the pupal state till August, when they come forth as moths to lay eggs.

Remedies.-(1) Search for the "tents" containing the larve in winter, and burn them. (2) Spraving the foliage thoroughly with Paris Green (Formula No. 11) and Arsionate of Lead (Formula 10) solution in summer, when the larvie are moving about freely, will destroy them.

Bud Moth (Hedya ocellana). - A small moth, measuring about half an inch across its expanded wings. The colour is a dark grey, with black spots near the tips of the upper wings. The moths appear in June and July, and usually fly at night. The eggs, which are laid on the leaves, hatch out in about ten days, and then, under the shelter of a fine web, they feed on the leaves until the latter are fully matured. In autumn they reparr to the bases of the buds, and shelter themselves for the winter in a silken kind of case. In spring the reddish-brown larvie with black heads emerge from the cases, and when the buds begin to develop they spin the young foliage blossoms together by a web, and cause the latter to shrivel ant turn brown. The apple and the cherry are specially attäcked by this pest.

Remedes.-Spraying late in summer with Formulie Nos. 10 or 11 would rlestroy the young larva. Another spraying when the buds are about to burst woukl also be beneficial. 
Codling Moth (Carpocapsa pomenella).-The larra of this moth is a very troublesome pest, not only in Britain, but also in France, Germany, America, Canada, Turkey, Australia, and Tasmania. In fact, it has proved so destructive in the latter country that a special Act of Parliament has had to be passed to secure its eradication. The injuries wrought by the larve of this moth may easily be detected in English orchards. For instance, any fallen fruit with a hole in it, when cut open, will in all proba-
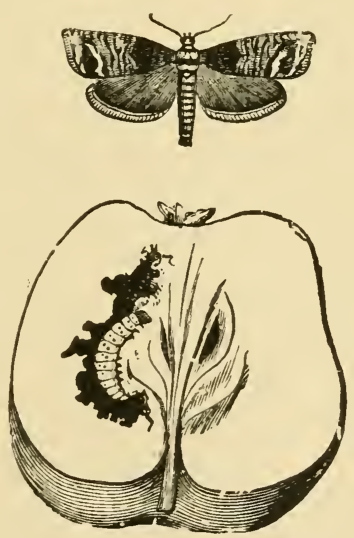

CODLING MOTH AND GRUB (CARPOCAPSA POMENELLA).

Note, the grub is seen inside the fruit.

hility contain a grub, or a cavity or tumnel made by it. The parent of the caterpillar is a small moth, measuring three-quarters of an inch across the wings and one-third of an inch in length. It has grey fore and dark golden hind wings. It appears about the end of May, and may be seen filting from tree to tree in the twilight or very early in the inorning. The moth deposits one egg on each newly-formed fruit, and in a few days a caterpillar is hatched therefrom, which immediately bores into the flesh. It remains in the fruit from three to four 
weels, till fully grown, then escapes and lets itself down to the ground by means of a silken thread. Sometimes the injuries caused by the caterpillar cause the fruit to fall off, and then the caterpillar easily crawls out on to the ground. Directly the caterpillar leaves the fruit it crawls along to the nearest tree and ascends it, finds its way into the first crack or crevice, and surrounds itself with a silken case gummed orer with a sticky fluid. Here it remains till the spring, when it appears as a perfect insect in May.

Remedies.-(1) Pick up and burn all fruit that has fallen early on the ground, and that shows evidence of being worm-eaten. (2) Grease-band the trunks, as advised in the remedies for the Winter Moth, taking special care to see the grease paper is kept thoroughly moist and frequently smeared with the grease. This smearing must be continued during May and June, and into the early part of July; then the caterpillans, which have let themselves down from the fruit, when they try to ascend the trunks will be easily caught. (3) Spray the trees directly the petals fall with Paris Green solution or Lead Arsenate spray solution (Nos. 10 and 11). This will destroy any eggs that may have been laid upon the young fruit; repeat the spraying a fortnight later. (4) All dead rubbish, etc., that may have accumulated underneath the trees should be carefully gathered and burnt, so as to prevent the possibility of any larve or pupe escaping. (5) Wrap a hayband, or strips of old sacking, around the trunk of each tree early in June; let this remain till winter; then remove and burn. The hay will serve as a trap for the larvie or pupae.

Figure-of-Eight Moth (1)iloba caruleocephala).The larve of this moth, commonly known as the Blue. hearl Caterpillar, occasionally does injury to the foliage of the apple and plum. The parent measures about one inch to an inch and a-quarter in the spread of its wings. It has brownish or greyish-brown forewings, marked with 
black hines, white spots, and brownish hindwings. The female lays its eggs singly during September on the branches and shoots of the trees. The eggs remain until the following spring, when from these are hatched caterpillars of a dull green colour, marked with a yellow stripe along their back, and with black-spotterd rings. They at once commence to feed on the roung foliage, and continue to do so until the middle of June, when they begin tor make their cocoons, and enter into the pupal state. The cocoons are generally attached to the stems of the trees

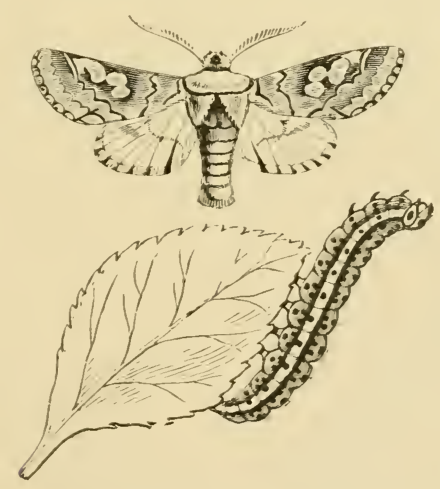

FIGTLE OF \& MOTH (DILOB.I CARULEOCEPHALA.)

or to walls or fences. The perfect insect emerges early in September, and then conmences its work of egg-laying, as previously described.

Remedies. - (1) In the event of the larra infesting the foliage, spray thoroughly with Soft Shap and Quassia (Formula 14), Kerosene Emulsion (Formula 16), or Paris Green (Formula 11). As the caterpillars attach themselves only very slightly to the trees, it appears they may be easily shaken off on to sheets spread below, then collected and destroyerl. 
Fruit Tree Beetle (Scolytus rugulosus).-Both the beetle and the larvie are injurious to fruit trees, boring galleries just underneath the bark, as well as riddling the latter with shot-like holes on the surface. The beetle is small, about one-tenth of an inch long, and black in colour. The females fly in April and May, alight on a trunk or branch or shoot, and bore holes half an inch long between the inner bark and sap wood, and there deposit their eggis. In a few days maggots appear, and begin to form chamnels at right angles to the main one, thus practically honeycombing the imner bark, and cutting off the supply of sap to the foliage. There are two broods of these beetles in a year. After pupation the beetles make their escape through the ruined bark. The larva is milkywhite in colour, legless, has a yellow hear, and strong brown mandibles.

Remedes.--Once the beetles or larve are inside the bark it is impossible to get at them. The best thing to do with a tree that is attacked is to cut it down and burn it forthwith, so as to destroy both beetles and larve. Shoots or branches that show signs of dying are likely to be infested, and should be cut off and burnt at once.

Fruit Tree Tortrix (Semasia woberiana). - The larve of this small moth feed on the inner barl of young fruit trees, causing cankered wounds to form, and subsequent ill-health of the trees. The moth is of a brown and black colour, streaked with orange and white, and has fringed wings. It only measures half an inch in diameter when its wings are expanded. The larva is small, white, striped with pink. The larve of another moth, the Apple Clearwing (Egeria myopiformis) is often found infesting the bark of apple trees, in company with the above larvie.

Remenes. - Wherever the bark has a sickly look remore a portion, and if the larve are seen pare off the infested parts and paint with Stockholm tar. Spraying the trunks 
with Formulie Nos. J or 8 in February will help to check the increase of this pest.

Goat Moth (Cossus ligniperla).-The moth lays its eggs in the crevices of the bark, generally near the gromd. From these maggots are latched, which, after feeding under the bark while roung, bore into the heart

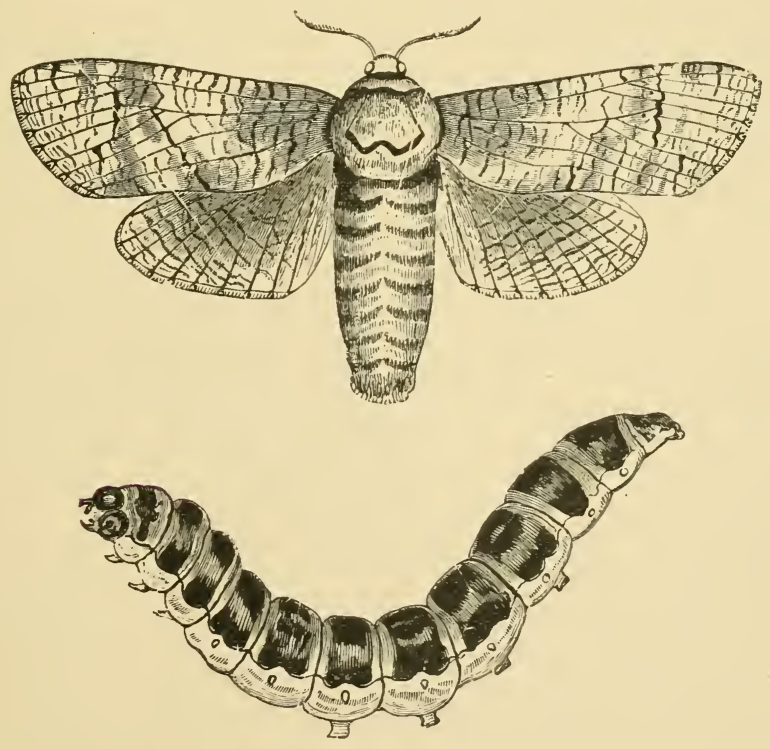

GOAT WOTH (YOSSL' LIGNIPELDA), AND L.IRV.I.

Both of natural size.

of the tree. They are of a reddish mahogany colour, with yellowish sides. If several happen to attack a tree they soon render it unhealthy, if not kill it. The caterpillar's are three years arriving at maturity, when they measure 3 to 4 in. long, and during that time are busy feeding on the wood, They rest, however, in the winter. 
Remenies. - (1) If the branch be dead or dying cut it off, and saw into sections to discover the marauders. When trees are attacked the best remedy is to thrust stout wire into the holes; it is impossible to reach the caterpillars in any other way. If you can get at any of the contents of buttertly-killing bottles, or cyanide of potassium or chloroform, place a little of either in the hole and seal up with wax, clay, ete. The odour will kill all caterpillars. Paraffin oil, tobacco juice, and sulphur fumes are each good, forced into the burrows by means of a piece of inkliarubber tube fixed to the nozzle of a svringe or fumigrator.

Green-Ieaf Weevil (Phyllobius maculicomis). - This little wrevil measures one-sixth of an inch in length, has yellowish-red horns, black legs, brown shanks and feet, and a golden-yellow scaly body. It infests the foliage of cherries, plums, apples, and nuts, and devous the soft portions of the leaves. In some seasons and districts the weevils are very prevalent, and do an immense amount of injury.

Remesy. - The only satisfactory remeily is to spreal sheets beneath the trees, and to suddenly and vigorously shalie the branches, so as to dislodge the weevils. Lilie other weevils, when disturbed ther feign death for a short time; consequently when they fall on the sheets they will remain quiet sufficiently long to enable them to be collected and destroyed.

Lackey Moth (Clissiocampa neustria).-The larve of this moth congregate in colonies under webs, and devour the leaves. The parent has wings from one to one and a-half inches in width, reddish-brown forewings barred with dusky brown; hind-wings of similar colour or paler. Both male and female moths appear in July, August, and September. The female deposits its eggs in rings on the shoots, each ring consisting of upwards of two hundred eggs. The eggs hatch in April. At first the larve are black and hairy, but when approaching maturity they turn 
to a bluish grey, with two black spots on their heads and the first segment, three orange stripes along each side, a white one down the back. with a black one on each sick. of this. The body is one and a-half inches long, and corered with rusty hairs. They shelter under the webs on wet days, and at nights are very timid and easily shaken off the branches. The larve are fully grown by the end of June; then enter into the pupal stage, the cocoons being found either in crevices of the bark or in the grass beneath.

Remedies.-(1) Cut off and burn any shoots encircled by bands of eggs. (2) Collect the webs by hand and destroy
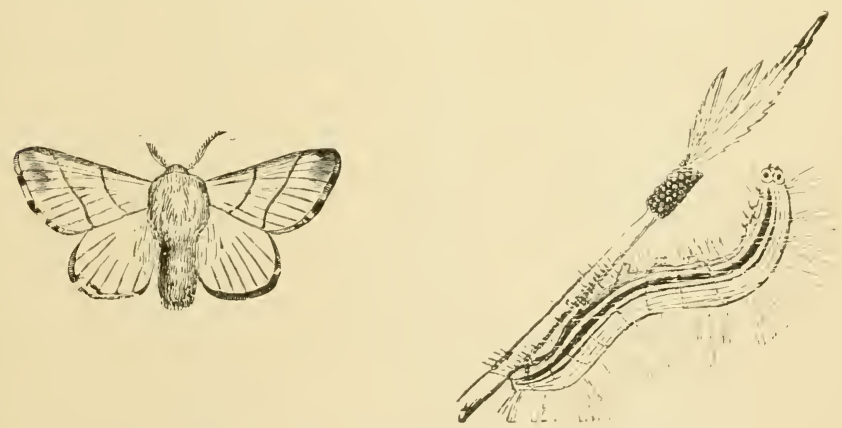

L.ACKEY MOTH AND LAFIA (BOMLYX NEU:TR.I).

them. (3) Spray the foliage with Paris Green (No. 11) or Arsenate of Lead (No. 10) solutions.

Lichen and Moss.-These are regetable parasites, and a word must be said about them in this section, because they have some connection with insect pests. In the first place they form a harbour or refuge for the ora, larve, or pupie of insect pests, and in the second one they render the bark unhealthy by reason of their growing upon it. It is therefore most desirable that moss and lichen should not be permitted to grow on fruit trees, as is so often the case. 
Renedr.- The remedy is a simple one-that of spraying the trunks and branches in winter with Formulic Nos. 1 and 2.

Miscellaneous Pests. - While the foregoing are the chief pests, there are others capable of doing occasional

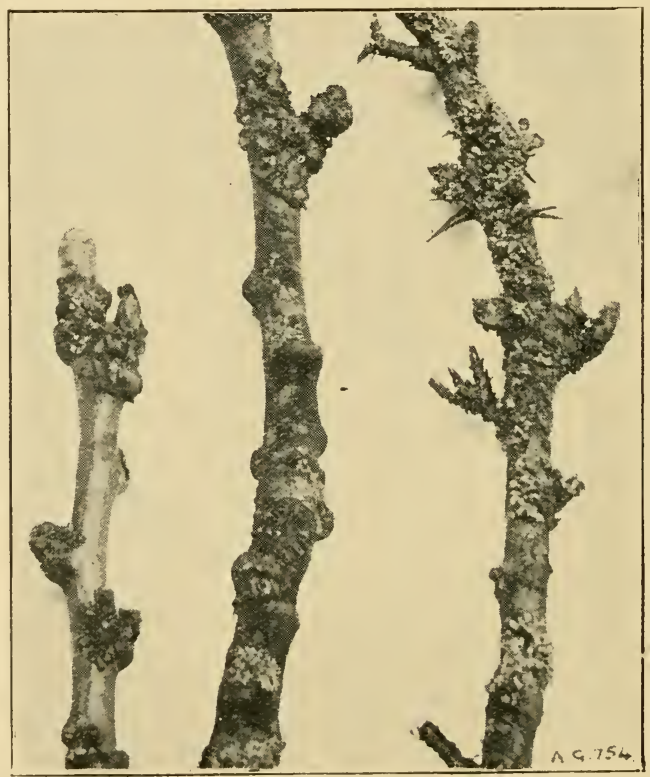

[Photo: H. A. Smith. APPLE SHOOTS INFESTED WITH I.ICHEX.

Trees growing in damp, heavy soìs are ellbject to having mose and lichen growing on the hark.

harm, but our space will not permit us to deal with these in detail. Thus the larva of the Fyed-Hawk Moth (Smerinthus oculatus), Lappet Moth (I assiocampa quercifolia), Crold-tailed Moth (Porthesia similis), December Moth (Pacilocampa populi), Grey Trident Moth (Acronycta 
psi), Pepper-and-Salt Moth (Amphidasys betularix), ('louded Drab Moth (Treniocampa incerta), Green Pug Moth (Chloroclystis rectangulata), Common Tortrix Moth (Tortrix ribeana), Apple Leaf-Miner Moth (Lyonetia clerckella), and the Apple-Leaf Blister Moth (Omix petiolella) either feed on the leaves, buds, or blossoms to a limited extent. Then various weevils (Rhynchites species) also feed on the foliage. Those, howerer, we have desuribed in detail are the chief culprits.

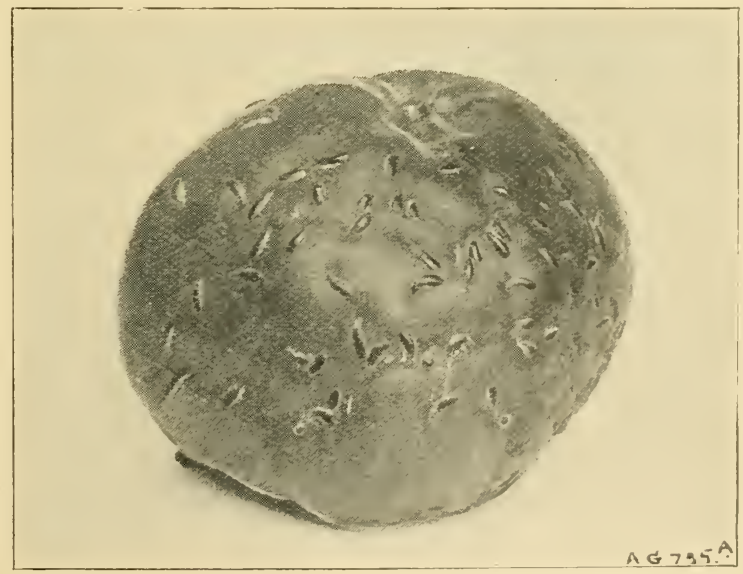

[Photo: H. A. Smith.

MUSSEL SCALE ON AN APPLE.

The scales in this caee have attacked the fruit as well as the branches.

Mussel Scale (Lepidosaphes ulmi). - This is an insect resembling in shape the mussel, hence its name. It is sometimes found congregated in large quantities on the shoots of apple trees, and when so present it does an immense amount of harm by sucking the sap. If one of the scales be removed the adult and young insects will be found ensconced beneath. The outer corering that is visible to the eye is therefore not the insect, but, as just 
explained, the covering or shelter for it. Tho youmer scales are small, flat, and white, and each one is furnished with a sucker-like apparatus, with which it pierces the tissues of the shoots to get at the sap. The insects multiply very fast, consequently will rery soon cover the shoots entirely if not checlied.

Riemenies. - (1) The best time to get rid of these pests is in winter. After pruming spray the tree with Canstic Mlliali II ash (Nos. 1 or 8), or with a lime, sulphur, and salt spray (Formula No. 5). (2) Paint the wood with the following solution: (One ounce of soft soap, 11b. of tobateces laper, and toz. of sulphur to one gallon of water. Mix thoroughly, and apply with a painter's brush.

Oyster-shell Bark Louse (Aspirliotus ostraformis). - I scale insect which infests the bark of the apple, pear, plum, apricot, nectarine, and peach. The perfect insect is somewhat like an oyster-shell in shape, hence its name, and usually of the same colour as the bark. The female scales are wingless and the males winged. The latter appear in April and May, and fertilise the females, which in due course produce eggs that hatch into larvie in Jume and July. Once the larve have found a congenial spot they settle down to pierce the bark and feed on the sap), cradually covering themselves with the oyster-like shell. This pest is capable of doing serious hain to the trees, so should be promptly dealt with.

Rembons. - Spray the trees thoroughly with Formulic Nos. 1, 2, 3, or 5, in February, or smear the bak with a pigment of cow-dung, lime, and clay in winter. The former plan is the most effectual.

Pith Moth (Blastodacua vinolentella). - The larve of this moth do a great deal of injury to the young shoots of fruit trees. 'The parent is a small moth with wings half an inch in width. The colour varies, but the forewings are generaliy black, barred with white or mottled with blackand-brown: hindwings grey; head white. The moths appear 
in June and July, lay their eggs on the leares, on which the larve feed for a time. Late in autumn the larve bore into the bark or ends of the shoots, remain there till Jamuary or later, then tumnel into the centre of the shoot and feed on the pith. The laive remain in the shoots till June, then issue as full-grown moths. Their presence may be easily detected by the withering of the foliage and the turning brown of the shoots. The larva when full grown measures one-third of an inch in length, and is of a dull reddishbrown colour.

Remeny. - It appears that the only satisfactory remedy is to cut off all withered shoots and promptly burn them. Insecticides are useless, as it is difficult to reach the larvar.
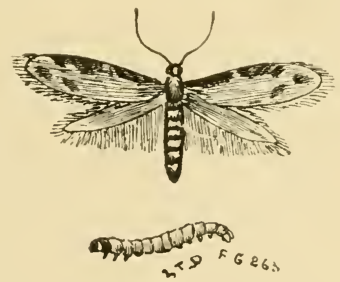

PITH JOTH IVU LARTA (BLASTJDACXI VISOLENTELA).

Shot Borer, or Apple Bark Beetle (Xylebolis (lispar).-Apple, plum, and pear trees are liable to be infested with a small beetle measuring about an eighth of an inch long. It bores its way through the bark into the stem and pith of the trunk and branches of the tree. From the first horizontal boring other borings are made up and lown the stem by these pests. In the event of a number of beetles taking possession of the tree they will in a very short time so tunnel the stem as to rery seriously injure the growth of the tree; in fact, where the beetles arc exceedingly numerous and the tunnels extensive, the tree dies as a consequence. The beetle attacks both young and old trees. Another species, called the Flat-celled 
Borer Beetle (Xyleborus saxeseni) is also said to attack the trunks of plum trees, and to do them considerable injury.

Remenies. - Once the tree is badly attacked there is no cure. The only thing to do is to cut it down and immediately burn it, so as to destroy the beetles, their larva, and eggs. If there be any suspicion that the beetles are attacking trees in the district, it is advisable to smear the trunks over with a mixture of soft soap and washing soda. It is also recommended to lightly brush or spray the bark with kerosene oil at the beginning of the attack.
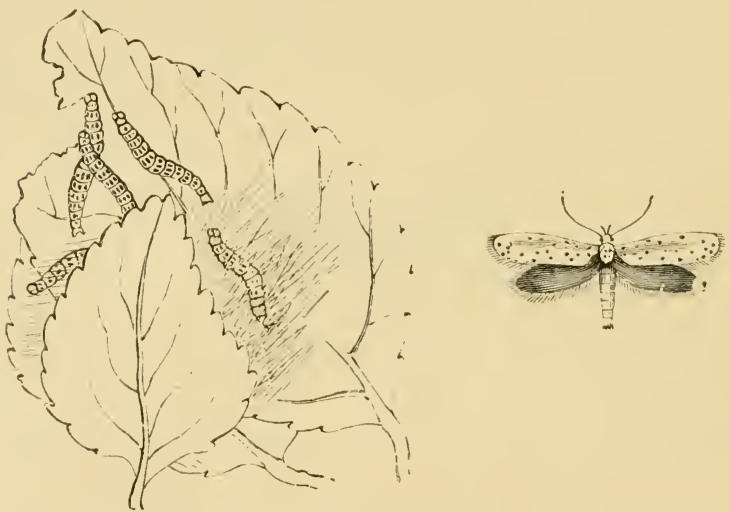

SMALL ERMINE MOTH (HYPONOMUNTA PADELLUS).

Small Ermine Moths (Hyponomeuta padella, conymella, and mallinella).--There are three species of what are popularly known as Ermine Moths, which infest fruit trees. H. padella measures four-fifths of an inch in the spread of its wings, has bluish or greyish-white forewings spotted with black, and greyish-brown hindwings. H. evonymella has wings an inch wide, and white wings with fine rows of black spots. H. mallinella resembles the first species very closely. The caterpillars are ashy-white spotted with black, and when full grown of a 
dirty yellow or lead colour. The moths are on the wing from the middle of July to the middle of August, when they lay their eggs in clusters on the buds and shoots. The eggs hatch either in autumn or the following spring, and in May the larve spin a web, under which they live in colonies. Thenceforward they feed ravenously on the foliage, devouring every particle of the soft tissue. As soon as full grown each caterpillar spins a cocoon, and pupates in this till it emerges in July as a moth, to again begin egg-laying.

Remedies.-(1) On low trees crush the caterpillars by grasping the web with the hand, or set fire to them by means of a torch. (2) Spraying thoroughly with Kercsene Emulsion (No. 16) will destroy the larva. Winter spraying with Formula No. 1 might kill the young larvæ.

Twig-cutting Weevils. - Two species of weevilsRhynchites cieruleus and interpunctatus, but the firstnamed more especially - do damage to the young shoots of apple trees. The female deposits an egg in a hole previously marle, about two or three inches from the point of the shoot, and then she sets to work to sever the twig just below the hole containing the egg. The portion either falls to the ground or hangs by a fragment of bark, and the egg gives birth to a grub which proceeds to feed on the pith until it reaches maturity, when it pupates in the soil.

Remedy.-The only one is to shake off the weevils on to sheets spread on the ground. Any shoots found eaten off should be burnt.

Winter Moths.-Several moths-notably, the Winter Moth (Cheimatobia brumata); Great Winter, or Mottled Umber, Moth (Hybernia defoliaria); Scarce Umber ( $\mathrm{Hy}$ bernia aurantiaria); Great Brindled Beauty (Phigalia pilosaria); Small Brindler Beauty (Nyssia hispidaria); Belted Beauty (Nyssia zonaria); and March Moth (Anisopteryx rescularia) are responsible for doing an immense amount 
of mischief to fruit trees. The females in each case are wingless, and crawl up the trumlis in autumn, winter, or spring, and lay their eggs in crevices of the bark. The two worst culprits are the Winter and Great Winter Moths. Both appear early in October, and begin egg-laying in carnest. The Winter Moth lays as many as two hundred ('vlindrical, green-coloured eggs, in lines or groups, in cre-

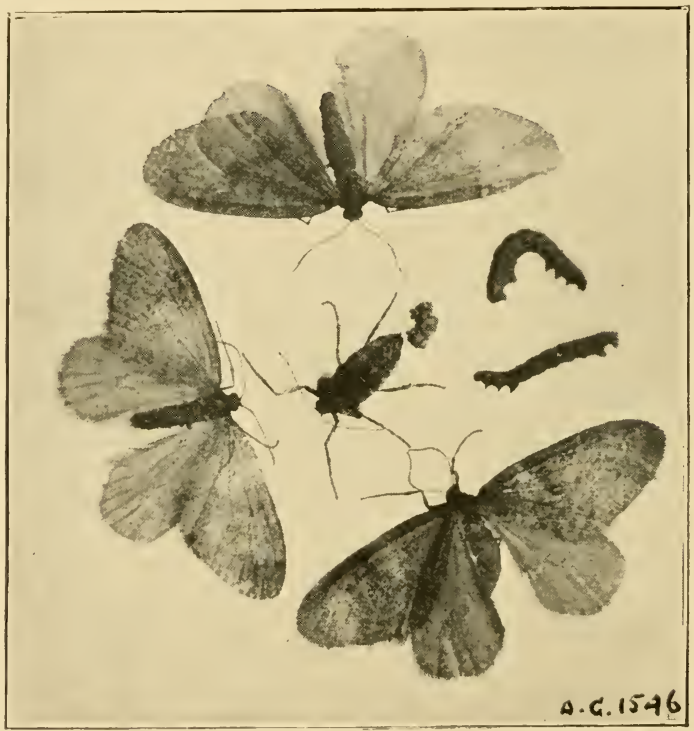

WIXTL HUTH (WRLED MALE, ONE WINGLESS FEMALE); Caterpillars and Group of Eggs Slightly Enlarged.

vices, and the Great Winter Moth upwards of four hundred large, rusty-coloured eggs. The eggs hatch as soon as the buds begin to burst. The larvie of the Winter Moth are grey at first, then greenish with white stripes and hown heads. They measure about three-quarters of an inch long, and form loops with their boslics when walking. As the lears form so they glue them together, and feed 
on them. When fully ferl they let themselves down to the ground by silken threads, burying themselves in the earth, finally emerging as moths in October and November. The larve of the Great Winter Moth are one and a quarter inches long, chestnut-brown in colour, with rellow under sides. They also form their bodies into loops, and act and feed similarly to those of the Winter Moth. As to the March Moth, this usually lays its eggs in March in bands round the shoots. Each female wingless moth if said to lay as many as five hundred eggs. In due course "looper" caterpillars of a whitish or greenish colour appear, and set to work to aid the other larve in their nefarious business of derouring the foliage.

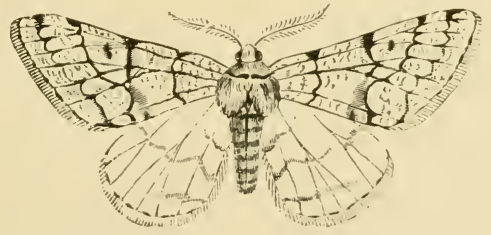

A.

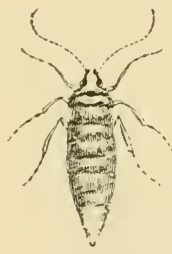

Ii.

GLEAT BRINDLED BEAETY MOTH PHIGALIA PILOSIRIA.

d. the male; $B$. the remale moth.

liemenes. - (1) We have already explained that the females are wingless, and that they have to crawl up the trees to lay their eggs. Experience, therefore, has shown that it is the business of the fruit-grower to prevent the females ascending the trees, and this is done by a process known as grease-banding. This consists of surrounding the trunk near the crutch with wide bands (twelve inches or more) of grease-proof paper, such as is used by grocens, and securing this tightly by three strands of twine-one at the bottom, one in the middle, and one at the top. This done, smear the paper with cart grease free from tar. The bands must be fixed early in October, and kept on practically all the year, renewing them in October. 
Examine the bands frequently to see if the grease is moist. If at all dry, adrl more. Do this till December. Early in March again grease the bands, and continue to do so til! well into July; then you will trap the female March Moth, the Apple Blossom Weevil in May, and the Codling Moth larve in June, and so circumvent their possibilities of doing mischief. (2) In the case of caterpillars infesting the trees, spraying with Paris Green (Formula No. 11) or Lead Arsenate (Formula 10), will either render the foliage unpalatable or lill the larve. These washes must, how-

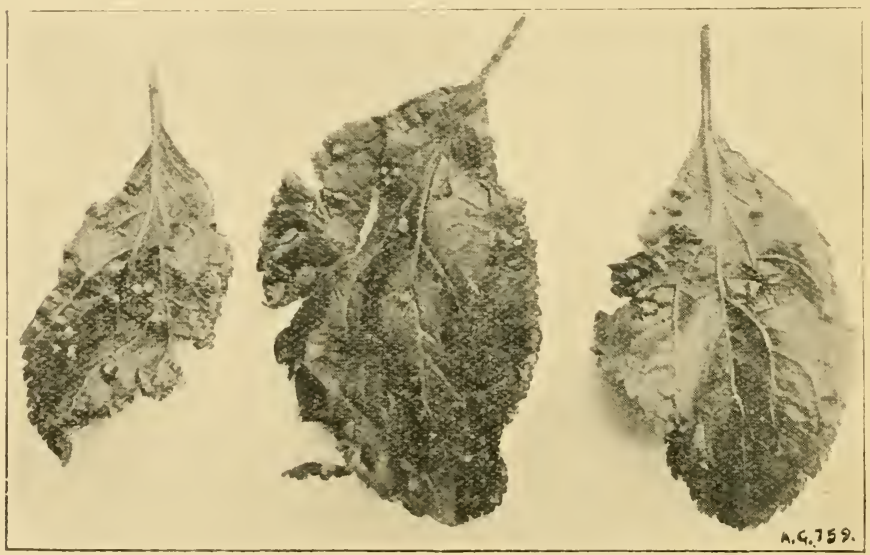

[l'hoto: H. A. smith.

IPILE LEALE INFEOTED WTHH GALLS.

Apple leares are sometimes furniehed with small protuberances, evidently the Wcrk of Gall Ilidgee or Mites.

ever, be applied just before the blossoms open and directly the truit has set to be effectual. (3) Spraying the trees with Caustic Alkali Wash (Nos. 1 or 8) in February will also kill the eggs.

Wood Leopard Motn (Zenzela asculi). - The larve of this pretty moth bore into the branches and trunks 
of fruit and other trees, and eventually cause their illhealth or death. 'The moths are fairly large, creamy-white, and spotted with black. They fly in the evening, rest on the trunks of trees or palings by day, and are to be seen from June to August. The female lays its oval, orangecoloured eggs upon the bark of the trees, and from these are hatched in a few days sellowish-white larve, which at once commence to bore into the bark. In the winter they bore further into the tree, and feed almost continuously until they are tro years old, when they enter into the pupal stage about May, and finally emerge as moths in Jume. When approaching maturity the larva measures about two inches in length, and is of a creamy-yellow tint spotted with black.

Rementes. - The presence of larve in trees may be detected by holes in the trunk or branches, and by traces of " frass," or small particles of wood, on the bark. It is difficult to get at them, however, owing to the depth and turnings of the galleries they make. Thrusting a hot wire into the holes as far as it will go, or forcing soap suds, (arbolic acid, and parattin emulsion into them are the only remedies short of cutting the tree down and burning it.

Other Pests.-Besirles the foregoing there are a number of other pests, but they are not of serious importance. Anyway, want of space prevents us describing them, and so we must pass them by.

\section{B.-APPLE DISEASES.}

Apple Mildew (Spherotheca mali).-This fungus attacks the roung shoots and leaves of the apple, covering them with a dense white powder in summer, and crippling their growth. It attacks old rather than young trees.

Remedies.-(1) In cases of bad attack cut off and burn the infected shoots. (2) Spray the leaves whilst young with Sulphide of Potassium Solution (No. 23).

Apple scab (Fusicladium dendriticum). - A fungoid parasite, which in some seasons and in some districts does 
a good deal of harm to the foliage and fruit of apple trees. The fungus first attacks the leaves, its presence being indicated by roundish black spots on the under and upper surfaces. The spots erentually increase in size, coalesce, and form patches. In due course the fungus spreads to the fruit, causing these to become spotted and cracked,

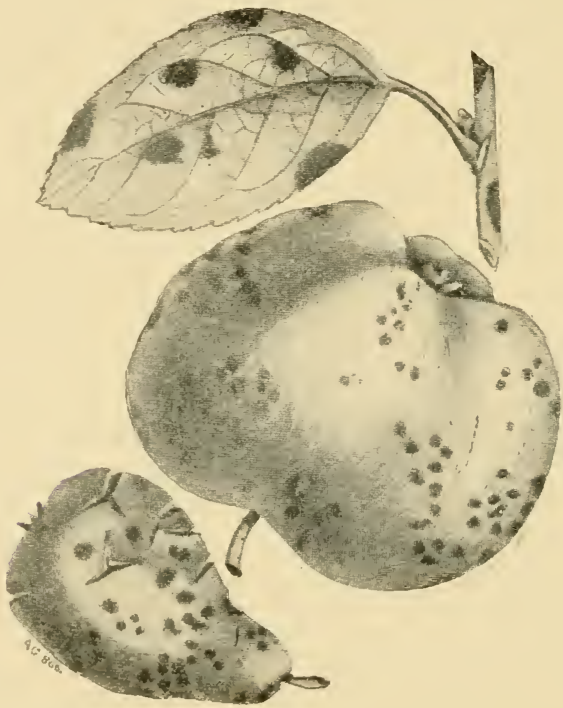

APPLE AND PEAR SCAB DISEASE.

The dark spots on the apple and leaf i!lustrated are eansed by Fusicladium dendriticum, and those on the pear by Fusicladium pirinum.

(From Boarl of Agrienlture Leaflot.)

and utterly maless for sale. When the disease is very rife it destroys the foliage as well as the fruit.

Revelies. - (1) All diseased fruit should be burnt, not given to pigs or thrown on the manure heap. Similarly in autumm, leaves that have fallen from infected trees shoukl be gathered and burnt. Fallen fruit and leaves contain the mycelium of the fungus, and this is liable to convey the disease to other trees unless destroyed. 
Spraying the trees with dilute Bordeaux Mixture (Nos. 20 or 2i) is a good preventive of the disease. Spray first when the buds begin to open; again when the petals fall; and, lastly, when the young fruit begins to form. It is also advisable to spray the trees thoroughly in winter with a sulphate of iron solution. (Formula 29).

Apple Tree Canker (Nectria ditissima).-This is one of the many diseases of fruit trees that, although very well known, is much more injurious than is generally supposed, judging from the rast number of infected trees that abound almost everywhere. Apple trees are invaded by the fungus in two different ways. When thick branches are attacked the disease almost invariably first appeirs in the fork of a branch, the wound that enabled the fungus to enter the tissues being caused by a crack, which is often formed when the branch is heavily laden with foliage or fruit. After infection the mycelium of the fungus first attacks the bark, which often eracks in concentric rings, and afterwards becomes irregularly cankered or eaten away; at a later stage the wood is also attacker, when the nutrition of the branch beyond the wound is interfered with, and, as a result of starvation, the production of both foliage and fruit is more or less checked. In addition to this, the spores of the fungus are produced in profusion on the cankered portion, which acts as a centre or nursery for furnishing the means of extending the disease to neighbouring trees. The second method of infection takes place on one-or two-year-old branches, the spores finding an entrance into the branch through punctures made in the tender bark by insects, hailstones, etc. This means of infection takes place in spite of the best possible methods of cultivation. What can be effected, however, by judicious pruning is to remove all surplus shoots, ant thus reduce the chances of infection; and even after the fungus has gained a foothold the prompt remoral of diseased branches is imperative, as in young, tender shoots the fungus acts much more vigorously than in the 
case of older, woorly branches; and it may be taken for granted that a young shoot, once attacked, is doomed, the bark being quickly destroyed quite down to the wood, the edges of the wound becoming thicliened and rugged. Finally, the wood is also attacked, and not infrequently much reduced in thickness, until at last the branch breaks

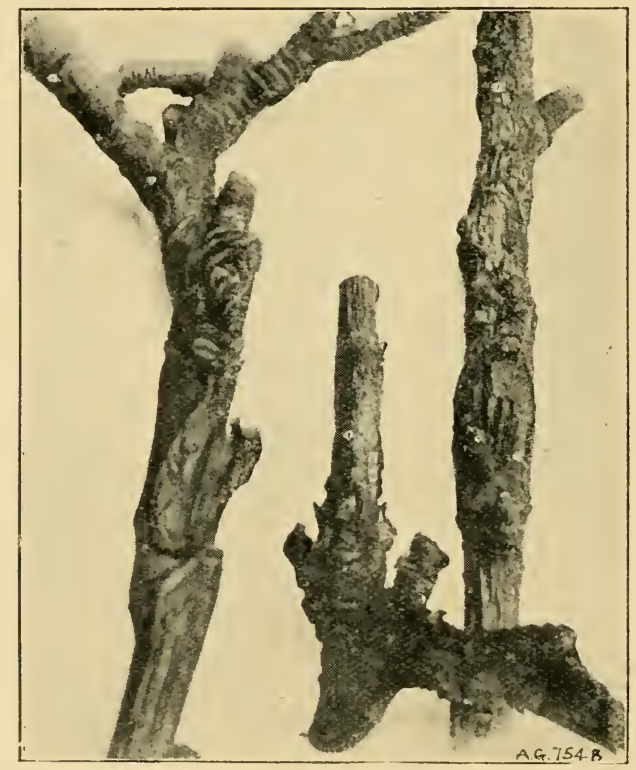

[Photo: H. A. Simith.

APPLE SHOOTA ITT.ICKED BY CANKER.

off at the wound. Like the majority of destructive parasites, the present fungus possesses two distinct kinds of fruit. The first form, which is most responsible for the spread of the disease, appears under the form of very minute tufts on the cankered portions of bark or woorl. 'The second form of fruit, which consists of a further development of the white tufts of the first form, matures 
during the summer and autumm, and is just visible to the eye as minute groups of blood-red, globose bodies, nestling in the rugged portions of the wounds.

Remedies. - As will have been gathered from the foregoing, judicious pruning both before and after the appearance of the disease is most essential. Where the pest has attacked stout branches the most certain method is to cut away the cankered portion of bark and wood and cover with clay, or paint with Stockholm tar. It is necessary to cut well behind the evidently infected parts, as the mycelium travels in the tissues for some time before external changes denote its presence, and if left in the branch a fresh outbreak is almost certain at a later date. Fallen, diseased twigs should not be allowed to lie under the trees, as the fungus forms fruit on such branches, which consequently prove a source of danger. The canker fungus is, unfortunately, by no means confined to apple trees, but also flourishes on many other kinds of trees and shrubs; hence it is necessary to keep a sharp look-out to see that the fungus is not introduced into the orchard from some outside source.

Brown Rot (Monilia fructigena).-This fungus is one of the commonest and most widely distributed of moulds against which the fruit grower has to contend. It attacks almost erery variety of orchard fruit, also many wild linds, especially those belonging to the order Rosacer. In this country it is most abundant on apples, although cherries and plums are by no means exempt from its attacks. The fungus usually appears first on the leaves, where it forms more or less effused, irregular, brown blotches, which eventually burst through the tisisue of the upper surface of the leaf under the form of minute, velvety patches of a brown colour. The velvety appearance is due to the fruit of the fungus, which consists of myriads of very minute, barrel-shaped spores, produced in chains. At maturity the spores become free, are then carried by rain, wind, birds, etc., on to the surface of 
healthy leares, fruit, or flowers, where, if conditions are favourable, inoculation takes place, and a new centre of disease is formed, which within a week produces a crop of spores. On the fruit the first outward sign of the presence of the fungus is a brownish discoloration of the

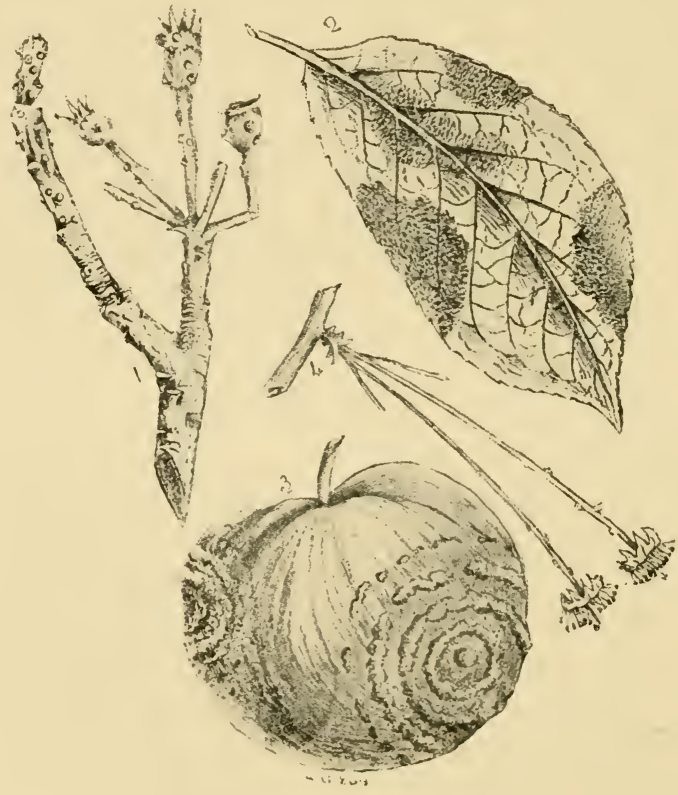

BROWN APPLE ROT DISEASE.

Fig. 1, Diseased shoot; 2, Leaf attacked by the fungus; 3 , Apple with fungus growing in concentrated rings thereon; 4 , Cherry blossom injured by the fungus.

(From Board of Agrienlture Leaflet.)

skin; this is followed by the appearance of numerous minute, velvety, greyish-olive tufts of mycelium, bearing long chains of spores; not infrequently the chains of spores are more or less branched. As the tufts of the fungus increase in number they are usually arranged in irregular circles round a central starting point, resembling 
miniature fairy rings, and eventually the entire surface of the fruit becomes corered with such tufts, which are hard and wart-like when okl. Fruit attacked by this fungus does not decay, but remains in a dry, mummified condition, either lying on the ground or hanging on the tree throughout the winter.

Remenes.-Gather all infected fruits and burn them. This work should be thoroughly done, remembering that " prevention is better than cure." If the diseased apples are thrown into the pig-sty or on to the manure heap the labour is all in vain, for, although the apples as such may disappear, many of the numerous sclerotia will survive, and in lue course bear a crop of spores. If the disease has existed during the previous season the trees should be sprayed with Bordeaux Mixture (Nos. 20 or 21), or with a solution of Potassium Sulphide (No. 23). The first spraying should be applied just when the leaves are unfolding, and two more sprayings at intervalis of three weeks. The object of these sprayings early in the season is to prevent the leaves from being attacked by the fungus, for if this happens it is almost impossible to prevent the disease passing on to the young fruit. Finally, if the disease has been present for some years, numerous spores are almost certain to be lurking in cracks of the bark, or sclerotia may be formed on the young diseased shoots of the past year. Under such circumstances it is advisable to thoroughly drench every part of the tree with a solution consisting of one pound of sulphate of iron to a gallon and a-half of water. It is important to remember that this mixture can only be used in the winter, before the leafburls begin to swell.

Coral Spot Disease (Nectria cinnabarina).-This is a fungus which usually lives on dead wood. However, its spores are likely to fall on fractures in the bark of living trees, germinate, and produce mycelium which develops under the bark, chokes the woor cells, cuts off the supply of food, and thus kills both leaves and branch. Its 
earliest presence may be detected by the appearance of bright coral-red spots on the bark. Apples, pears, currants, and other trees are liable to its attack.

Remenies. - Remove infected branches and burn them. If the trunk is infected burn the tree. Paint newly-made

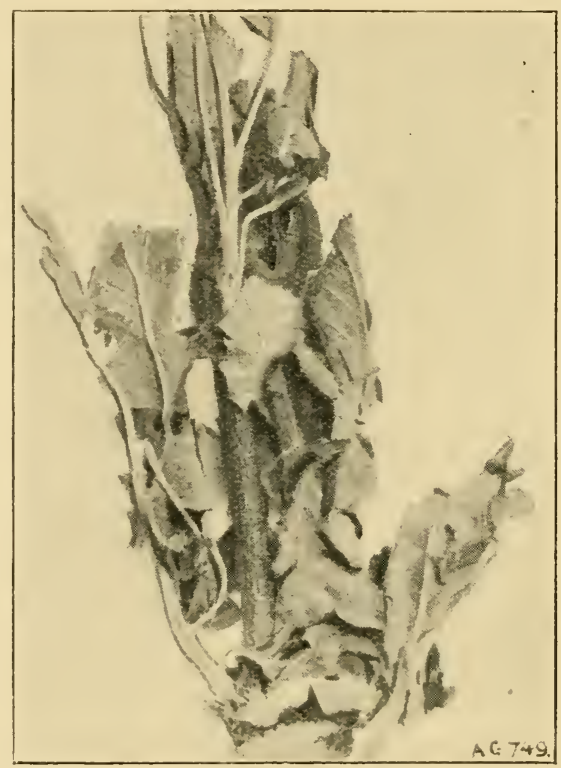

[Photo: H, A. Smith.

I DISEASE OF YOUNG FRUIT TREES.

A fungoid disease (Eutypella prunastri), which caltees the eudden shrivelling of the foliage and young wood.

wounds with tar, and burn every scrap of dead wood found with coral-red spots on them.

Disease of Young Fruit Trees.-Occasionally young standard and dwarf fruit trees, especially those growing in heavy clayey soils, show sudden indications of 
ill-health, due to the premature yellowing and falling of t!:e leaves, followed by the browning and shrivelling of the bark of the stems. This injury is caused by a parasitic fungus (Eutypella prunastri) developing in the bark and the cambium layer. The mature spores find their way into wounds caused by careless pruning or fractured bark in early summer, and these vegetate in due course and kill the bark. Trees are liable to attack up to ten years of age, and the disease is more active in damp seasons. Attacks the apple, plum, and cherry.

Remedies.-As a preventive paint the newly-made wounds at pruning time with Stockholm tar. At the same time paint the trunks with the following mixture, as advised by the Board of Agriculture: "Reduce soft soap to the consistency of paint by the addition of a strong solution of washing soda in water. Adk one pound of quicklime to every five gallons of mixture, and stir until the whole is thornughly dissolved. Apply to the trunk with a paint brush." Burn all dead trees.

Leaf-scald Fungus (Entomosporium maculatum). - This fungus attaclis the young leaves of pears, apples, peaches, cherries, plums, and roses, in the form of red spots, which afterwards change to brown, causing them to wither and fall off. In bad attacks the tree or plant is frequently defoliated early in the season.

Resedies.-(1) Spray with a dilute solution of Bordeaux Mixture (Formulie Nos. 20 or 21) just as the leaves begin to expand, repeating the application a week or so later. Gather and burn all infected leaves.

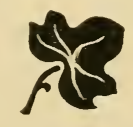




\section{CHAPTEP II.}

\section{APRICOT AND CHERRY PESTS.}

\section{A. INSECTS.}

Apricot Moth (Botodes angustiorana). - The larve of this small moth feed on the leaves of the apricot. The moth lays its eggs on the lwigs in summer, and from these are hatched greyish or yellowish-green caterpillar's, which roll the leaves together to form tubes wherein they feed on the foliage. When disturbed the larva descend by means of a fine sillien line. They are very active insects, and easily recognised.

Remedes. - Spraying in winter with Formula No. 5 to kill the eggs, or in summer with Formula No. 10 to kill the larve, are the best remedies. Hand-picking may also be practised where ouly a few larve are discovered.

Cherry Aphis (Myzus cerasi). - Small black plant lice which infest the under sides of the foliage of cherries in spring and summer, covering it with a sticky "honeydew," and causing both shoots and leaves to shrivel. The females are viviparous in spring and oviparous in autumn. Occasionally this pest is very numerous, and does serious injury to the trees.

linmenes. - Sipray the trees in summer with Formula No. 16, or in February with Formule Nos. 1 or 8, or in March with Formula No. 9.

Cherry Sawfly (Eriocampa limacina). - The larva of this fly, popularly known as Slugworms, do an immense amomint of injury in some seasons and some districts to the foliage of the pear and the cherry. The Sawfly is about a quarter of an inch long, black with dusky wings, 
and is usually met with in May or June. The fenıle, armed with a saw-like apparatus, makes an oval slit in the under side of the leaf, and deposits an egg within From half a dozen to a score of eggs may be deposited in each leaf. In seven to twelve days each egg gives birth to a small white larva, which eventually becomes green,

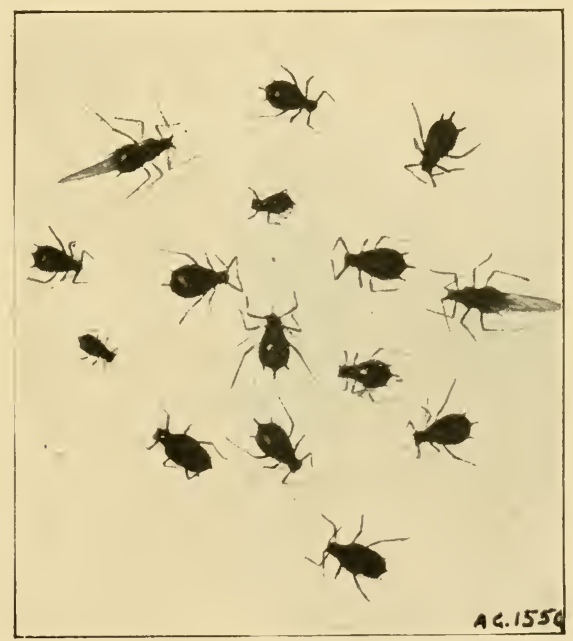

[Photo: J. G. Blakey.

CHERRY BLACK FLY (MYZUS CERASI).

An aphis which frequently does serious injury to cherries.

and afterwards covered with a dark slime. It then assumes a slug-like form, being large at the head and tapering at the tail. There are seven pairs of feet attached to its abdomen, three pairs to its thorax, and a pair of short sucker feet to its tail. It is very sluggish in its movements, and feeds on the soft tissues of the upper surface of the leaf, leaving the network of nerves and ribs below. At the end of a month it loses its slug-like form and slime, and changes to an orange-yellow colour. Dur- 
ing its development it moults, or casts its skin, five times. After the final one it crawls down to the earth and forms a dark pupa in a cell made of earth and silky threads.

Rementes. - (1) Spraying in summer with Paris Green (Formula No. 11) or Arsenate of Lead (Formula No. 10) fluids will poison the surface of the leaves on which the larve are feeding. (2) Where trees have been badly attacked the previous year give the surface of the soil a

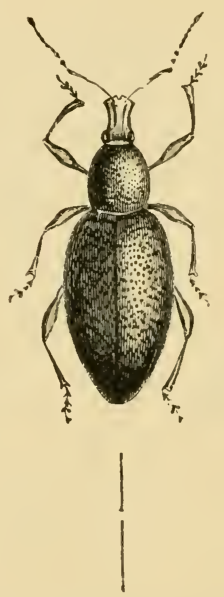

APRICOT WEEVIL (OTIORHYCHUS TENEBRICOSLS).

The vertical line indicatee the natural length of the weevil.

dressing of quicklime or kainit (1oz. per square yard), ol' soot in winter, and fork this in. (3) In the case of grass orchards an application of kainit (half a ton per acre) in winter will destroy the larve and feed the roots. Poultry should be turned freely into grass orchards to eat the pupa.

Cherry Tree Moth (Coleophora anatipenella).-A small creamy-white moth which flies about in the evening, and lays its eggs on the under sides of the leaves of 
the cherry, apple, etc., in August or September. The larve hatch out in late September or early October, and then envelop themselves in a case attached to the shoots. They feerl during the autumn, remain quiet during the winter, and in spring become active, then feeding on the young leaves and buds. The larve are reddish-brown or range in colour. They pupate in the case, which is pistol-shaped.

Rimmor. - Spray the trees in late summer or autumn with Formula No. 10.

Miscellanecus Apricot Pests. - The larve of the Winter, Mottled Umber, Bud, and Magpie Moths; also the Peach Aphis, Peach Scale, and the Red Weevil, occasionally attack the foliage of apricots. See index for references to these pests.

Other Pests. - The Fruit Tree Bark Beetle, Mottled Unber Moth, Winter Moth, Figure-of-Eight Moth, Lackey Moth, Golk-tailed Moth, Buff-tip Moth, Plum Tree Borer Moth, and Leaf Weevils, also attack the cherry, details of all of which are given elsewhere. See index.

\section{B.-DISEASES.}

Apricot Brown Rot (Monilia fruetigena). - A fungoid disease which attacks the fruit of the apple and apricot, causing it to rot. In some seasons it is very prevalent. Full particulars of it appear in the section devoted to diseases of the apple, in Chapter I.

Cherry Leaf scorch (Gnomonia erythrostoma).Although apparently an old disease, it is only recently that its existence has been brought prominently into notice by Mr. E. S. Salmon, F.L.S., mycologist to the Wye Agricultural College. In the September (1907) issue of the Board of Agriculture Journal he gave a detailed account of its life history. It appears that the spores of the fungus, when they fall on a young leaf, vegetate and develop a mycelium growth within the tissues, spreading 
among the cells and feeding on the salp. In due course vellow patches appear on the leaves, causing them to turn brown, shrivel, and die. The fumgus ceases development at the end of the leaf, leaving the stalk free. Sometimes the fruit also is attacked. The result is, the withered leaves do not fall off in autumn, but remain on the tree till the next season. Moreover, the natural functions of the leaf being (hecked, the sap usually drawn up by them to be elaborated and returned to make new wood and fruit buds cannot be properly dealt with, and the result is imporerished growth, a paucity of fruit buds, much dear wood, and the final death of the tree. Mr. Salmon says the disease is most pensistent on trees grown in poor and shallow soils. On deep and rich soils trees attacked have grown out of the disease in time. The existence of the disease is easily determined by the presence of withered foliage on trees in winter and spring.

Remeures.--Mr. Salmon says that if the withered leaves are gathered in winter and burnt the winter fruit of the fungus may thus be destroyed, and the spread of the disease checked. Spraying the trees with Bordeaux Mixture (Formula 20 or 21 ) just before the flowers open, and again after the petals have fallen, is said to be a good preventive.

Cherry Leaf spot (Cortneum Boijerinckii).-This disease attacks the leaves and roung shoots in the form of red spots on their under sides. Later the spots become hrown, the tissue dies and falls ont, leaving holes in the leavos. It alse attaclis the fruit, causing the flesh to shrivel.

liembry.-- Spray with Bordeaux Mixture (Formula 20 or 21) when the buds are begiming to expand.

Cherry Mildew (l'odosphera tridactyla). - This forms white patches on the leaves of young shoots, both sides being attacked. When very severe, it seriously injures the foliage. 
Remedes.-(1) Spray directly the mildew is observed with Potassium Sulphide (Formula 23). (2) Gather and burn fallen leaves.

Cherry and Plum Leaf Blight (Cylindrosporium Padi).-. This fungoid disease attackis the foliage of cherries and plums in a young state, forming small, round, purple spots, which ultimately turn brown, dry up, and cause holes to be made in the leaves. The Morello Cherry is specially liable to be attacked.

Remedy.-Spray with Bordeaux Mixture (Formula 20 or 21) when the leaves begin to expand.

Gummosis. - See chapter on "Plum Diseases."

\section{CURRANT AND GOOSEBERRY PESTS.}

\section{A.-INSECTS.}

Black Currant Bud Mite (Eriophyes ribis).-This almost microscopic creature has caused a great deal of anxiety to fruit growers of late years. In some districts it has been necessary to destroy the whole of the plantation, so badly were the trees infested. The mite-it is not an insect-can only be seen by the aid of a pocket lens. It is cylindrical in shape, has four short legs, and a short snout. The mites are to be found chiefly in the burls, where they puncture the embryo leaves and suck the sap, thus causing the cells to develop abnormally and the buds to become swollen, more or less roundish and plump, instead of pointed and thin. It appears that the eggs begin to hatch out about March, and that the young 
mites travel ahout the bushes in May and June, and later find a refuge in the young buds and under portions of rough hark on the wood.

lievenies.- In the case of a bad attack the proper remedy is to burn the bushes. Where only a few big buds are seen, pick these off and burn them. A good preventive measure is spraving the bushes with a mixture of lime and sulphur. Mix 1lb. of fresh lime and

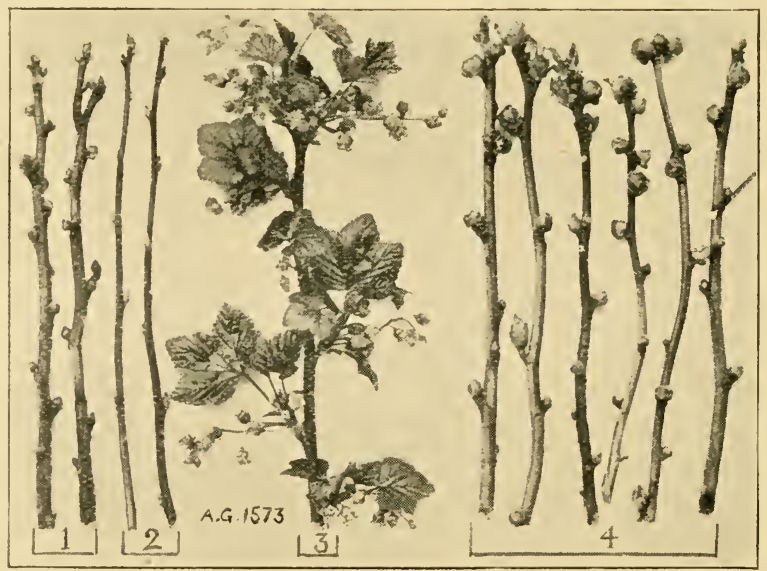

[Photo: J. G. Blakey.

BLACK CERRANT G.ILL OR BIG BUD MITE.

Fig. 1, shoots affected with the mite, photographed in January. Fig. Healthy shoots photographed at came time. Fig. 3, Healthy shoot photographed on May 5. Fig. 4, Infested shoote photographed on same dite.

1lb. of sulphur in 20 gallons of water, and spray the bushes in spring. Or, mix one part of fresh lime with two of sulphur, and dust this over the trees whilst wet in March, Ipril, and May.

Currant Aphides (lihopalosiphum ribis and Myzus ribis).-Two kinds of Aphides, or Plant Lice, frequently prove very injurious to currant trees. The Rhopalosiphum 


\section{CURRANT AND GOOSEBERRY PESTS.}

species possesses both wingless and winged females. The former are pale green, and one-tenth of an inch long. They make their first appearance in April, and occur at intervals up to August. They infest the under sides of the leaves, and cause red, orange, and yellow blisters to form on the upper surface. The winged female is yellowish-green with a black head, and flies from bush to bush. Both produce their young alive. Late in summer males and egg-producing females are born; and the latter, after being fertilised, lays her brown eggs on the twigs of the previous year's growth. The eggs remain till spring, then give birth to viviparous females. The other Aphis is Myzus ribis. The wingless female appears in the spring, is yellowish-green with red eyes, and gives birth to pale green larvæ. Later winged females appear of a bright green colour, olive head, black cornicles, and deep green legs. Finally, a brood of males and females appear, which lay their eggs on the shoots to give birth the following spring to viviparous females. They chiefly attack the ends of the shoots, causing them to curl and twist up.

Remedies.-(1) In the case of trees attacked the preceding year spray them thoroughly, after pruning, with Caustic Alkali Washes (Nos. 1 or 8). (2) Collect and burn all prunings. (3) If lice appear on the foliage in spring, spray with a Kerosene Emulsion (No. 16) or Quassia Wash (No. 14). To be effectual the spraying must be done before the blisters appear on the leaves, or the ends of the shoots become curled and twisted. In bad cases cut off the infested ends of shoots and burn them.

Currant Clearwing Moth (Egeria tipuliformis). This insect is found throughout the length and breadth of England and on the Continent, and has also been imported into America, where it has established itself as a very troublesome pest. In England the black currant bushes generally suffer most severely, becoming quite worthless when badly infested. Next in order the insects attack 
the red and white currant, gooseberry, nut bushes, and now and then the raspberry. The moth is a graceful, pretty little insect, with a black body relieved here and there by rellow lines; the wings are transparent and bordered with black, the forewings, which rarely exceed an inch from tip to tip, having a black bar across them. It is from the transparency of its wings that the moth has

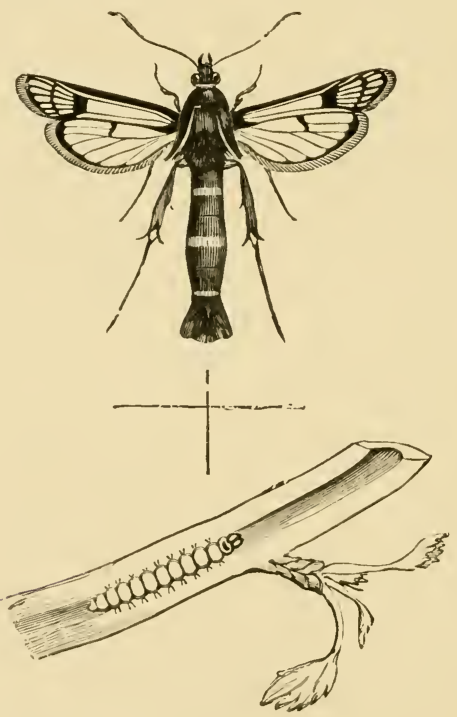

CURIANT CLIAR-WING MOTH (SELA TIPULIFORMIS).

The upper figure is the moth; the crose lines lelow indicate its natural eize; at the bottom io a shoot with the larva inside.

gained its popular name of "Clearwing." 'Tewards the end of June and the first weeks of July the female moth deposits her eggs singly upon the stems and in close proximity to the bukls. In a few days the tiny larva hatch out, and at once proceed to gnaw their way down through the bud into the centre of the stem. Here they excavate a considerable gallery, feeding on the pith 
throughout the summer and autumn, and enlarging the size of their tumiel home both in length and breadth as they increase in size. Just before changing to a chrysalis the larva excavates a passage nearly through the stem, only leaving the thin outer skin unbroken to protect the pupa from harm. Early in the following June the pupa pushes itself against this skin, so as to rupture it, and then, jerking itself half-way out of the newly-formed opening, rests for awhile. In a short time the skin of the chrysalis cracks and the perfect insect emerges, dries, expands its wings, and flies off. The larva when full grown measures barely half an inch in length; its body is a pale yellowish tint, with the hear a light chestnut colour, and the jaws slightly darker. It has sixteen feet -i.e., three pairs of claw-feet, four pairs of sucker feet beneath the body, and one pair of sucker feet beneath the tail.

liemedies. - In detecting the presence of this perst in its larval stage the fading condition of the leafage will be a pretty obvious guide. Every infested shoot should be cut off well below the bottom of the tunnel, so as to ensure having cut away the larva, and at once burnt. If the infested shoots are not at once burnt, but only cut off and thrown on one side, the larve are pretty sure to complete their metamorphosis, and appear again in due course.

Currant Pug Moth (Eupithecia assimilata).-The larve of this moth feed upon the foliage of the currant. The moth is small, of a blackish-brown colour, marked with a grey line. It appears in May and June. The larve are yellowish-green in colour, with a line of darkel green on the back and down each side. They are most active in late summer and early autumn.

Remedy.-Spray in autumn with Formula No. 10.

Currant shoot Moth (Incurvaria capitella). - The larvie of this moth have been found to injure the young shoots of currant trees by boring into and feeding upon 
their pith. It appears that the female lays its eggs upor. the fruit of the currant, and that the young caterpillar feeds, in its earlier stages, upon the seed in the fruit. In a short time it quits the fruit and scels the base of the buds on the shoots, there burying and hiding itself in a small cocoon to pass the winter. The following spring the caterpillar comes out of its cocoon, and then immediately starts and bores its way into, and feeds upon, the pith of the shoot. As a result the foliage begins to wither, and the shoot to die.

liemeDies.- Wherever the shoots are found to be withering in the spring they should be cut off and promptly burnt. Practically, this is really the only remedy that can be arlopted, as, owing to the caterpillars feeding inside the shoots, it is difficult to reach them by means of an insecticide.

Dot Moth (Mamestra persicaria).-In some seasons fruit trees are apt to be infested with the larve of the Jot Moth. When very prevalent this pest is very voracious, devouring the foliage to an alarming extent. It does not confine its attention to gooseberries alone; it is also very partial to the currant and raspberry. The caterpillars vary a good deal in colour. They have pale green or brown bodies, bordered on each side by a white line, and with a white line rumning down the back. When fully grown the caterpillar measures one and a-half inches or more in length. The parent has rich dark-brown forewings, marked with chestnut or rust, and with pale spots at the tips. In the centre of each wing is a conspicuous white dot, hence the common name. The caterpillars feed during summer and autumn, and commence to pupate about the end of September.

Remenies.--(1) Spray the infested bushes thoroughly with Kerosene Emulsion (No. 16). (2) Where only a few are present hand-picking is the best remedy.

Gooseberry and currant scale (Lecanium persicre sarothamni).-This insect infests the stems of the 
black, red, and white currant, and gooseberry. The scalylike corerings are merely shelters for the insects within. The female first lays a large number of very fine eggs. In lue course these eggs give birth to oval maggots, which at first move about until they have found a suitable position

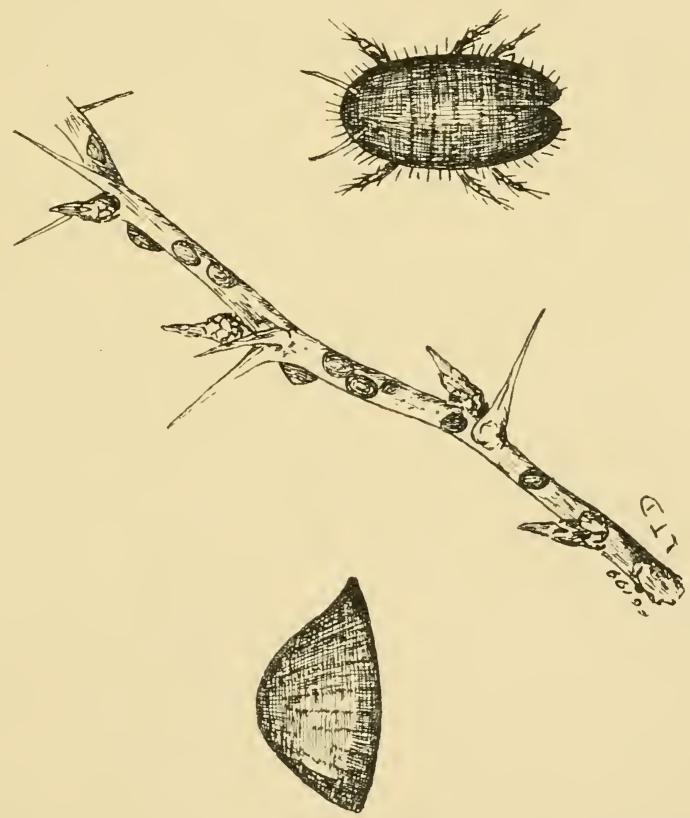

GOUSEBERRY SCALE (LECANIUM PERSICA SAROTHAMNI).

Upper figure represents the femaie and the lower one a eide view of the ecaly covering which shelters the young insecte.

on the branch. Then they settle down, insert their beak firmly into the bark, and there remain permanently during their short life. As each female lays such a multitude of eggs, it will be apparent that in a very short time there will be hundreds and thousands of these pests distributed all over the shoots of the tree. They pierce the bark and 
extract the sap from the cells, thus wounding the tissues, and preventing the plant carrying on its proper functions. There are two broods in a year.

Remenies. - Spraying the foliage thoroughly with Caustic Alkali Washes (Nos. 1 or 8) in winter. All infested prunings should be promptly burnt. Dusting quicklime among the branches in winter, while moist, will likewise help to destroy these pests. See also remedies advised for Mussel scale, on p. 71.

Gooseberry Red Spider (Bryobia ribis).-This is a small mite, or form of red spirler, which in very hot and dry seasons infests the leaves of the gooseberry to a very serious extent. Like the ordinary lied Spider of the garden and greenhouse, it dislikes moisture and cold; consequently, as already intimated, it is not likely to be very numerous or destructive, except in dry, hot seasons. The mite can hardly be seen individually iny the naked eye, but its presence may be easily detected on the foliage of the gooseberry by the pale colour, and by the fact of the surface being dotted with minute reddish spots, covered by a very thin silken web. On examining the foliage with a magnifying glass the web will be clearly seen, and underneath it the colony of mites. These mites puncture the epidermis of the leaf and extract the sap. They increase very rapidly; so much so that hundreds and thousandis may be found upon a single leaf.

Remenies.-Directly these pests are found infesting the leaves of the gooseberry the trees should at once be sprayed with a Kerosene Fmulsion (No. 16). One spraying may not be sufficient, so repeat the operation until all traces of the pest have disappeared.

Gooseberry Sawfly (Nematus ribesii).-Though called the Gooseberry Sawfly this pest is also very partial to the foliage of the red currant. The perfect insect appears late in April or early in May. It measures about one-third of an inch in length, has a dark-coloured head 
and thorax, yellowish legs, black feet, and a yellowish body. The female lays her eggs by the sides of the ribs underneath the leaves, and the larra hatch in about eight days. At first they are white with a few black spots and a black head. Later their colour changes to green, and finally light green with a yellow head. In about twenty days the larve enter the pupa stage. Usually there are
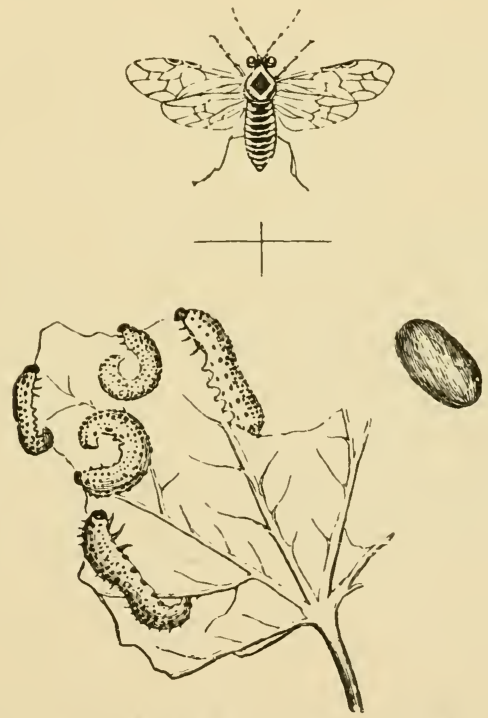

GOOSEBERRT AND CLRRANT SAWFLY (NEMATIS RIBE-II).

Above is the sawfly with line below to indicate its size. Below are the larva feeding on a leaf, with a cocoon at the eide.

from two to three broods of sawflies in a season. The larva feed on the soft tissues of the leaves, and generally leave nothing but the mid-ribs. They are very voracious, and if allowed to multiply unchecked will soon destroy a vast amount of foliage.

Remenies.-(1) Directly the caterpillar's are discovered spray the foliage with Formula No. 16. One or two spray- 
ings may be required. (2) In autumn fork freely into the soil Apterite, Kilogrub, or Vaporite, to asplivxiate the pupie.

Magpie Moth (Abraxas grossulariata).-Much injury is done in some seasons to the foliage of gooseberry, cur rant, and other trees by the larvie of this moth. The moth itself is a very pretty one, and may easily be recognised.

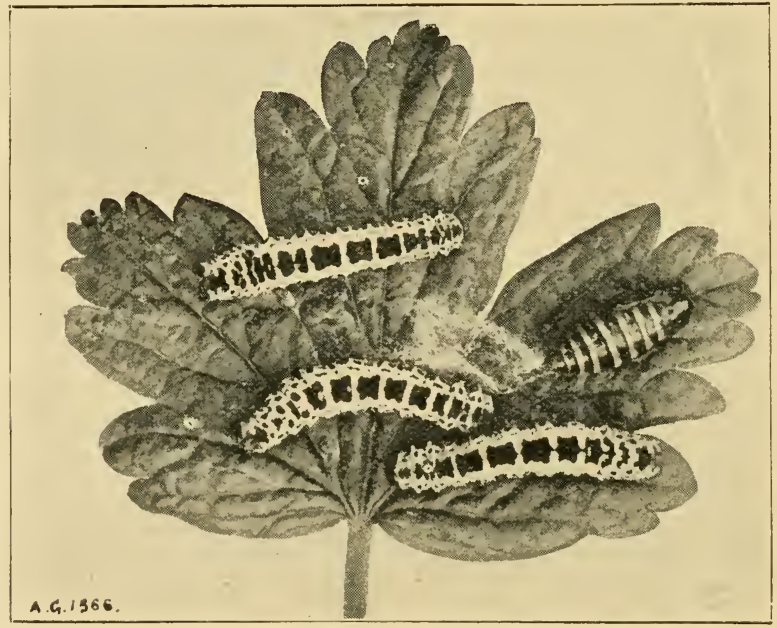

[Photo: J. G. Blakey.

CATERPILLARS AND PUPA OF MAGPE MOTH.

The three large insects are the larva, and the one shown to the right is the pupa.

It has a yellowish borly, and white wings spotted with: black. It generally makes its appearance late in summer, and lays its eggrs near the mid-ribs in groups of three or four, or singly, upon gooseberry or currant leaves. In ten days or so caterpillars are hatched, and these at once commence to feed voraciously upon the soft tissues of the foliage. The caterpillar is about one and a-quarter inches long and very prettily marked, with a band of dark orange extend- 
ing from its head to its tail. On each side below this there is a row of black spots, with two black stripes underneath the body. In the autumn the larve spin leaves together, or drop to the ground and remain just under its surface till the following spring, when they ascend the trees and immediately start to again feed upon the foliage. They are fully fed by June, then enter into the pupal stage and emerge as moths in August.

Remedies.-As soon as the caterpillars are observed in spring, splay with Formula 10 or 16 . Repeat the spraying again in September. In autumn fork Apterite, Kilogrub, or Vaporite freely into the soil to kill the hibernating larve.

White Woolly Currant scale (Pulvinaria ribesire). - These insects infest the shoots of both black and red currants. They exude a cottony or woolly matter, which rntirely corers their bodies, so that the insects themselves can scarcely be discerned. The young scales are whitish or orange in colour, and of a flattened, oral shape. Like other scale insects, they are furnished with a proboscis, by means of which they pierce the shoots and suck the sap, and consequently do much harm to the trees.

Remedies. - Spray in February with Formula Nos. 1 or 8.

Other Pests. - The gooseberry is also attacked by the Winter Moth, Gooseberry Aphis, Grey Slug, and Leaf Weevils; and the roots of currants, by the Woolly Aphis, or American Blight. See index.

\section{B. DISEASES.}

American Gooseberry Mildew (Sphærotheca mons-uvie). - This disease has caused a good deal of sensation in the fruit-growing and mycological world during the last year or so, and has been instrumental in inducing the Govermment to pass a special Act of Parliament to enable the Board of Agriculture to deal with and stamp it out in this country. The disease is of American origin. 
and the discovery of its appearance in England was largely, if not wholly, due to Mr. E. S. Salmon, F.L.S.,

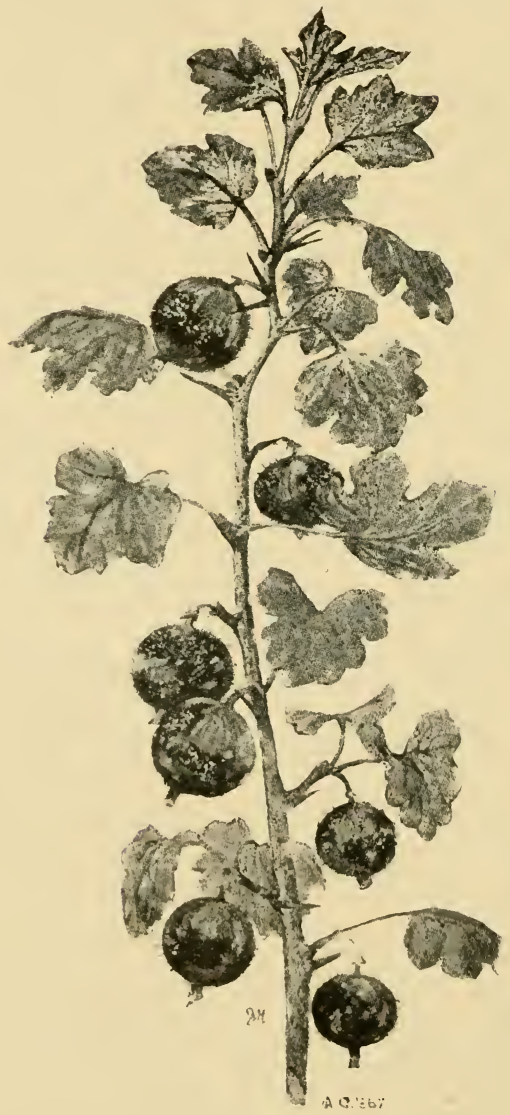

AMERICAN GOOSEBERRY MILDEW.

Showing a branch badly attacked by this disease.

(From Irish Board of Agrienlture Lenflet.)

mycologist to the Wye Agricultural College, Kent. It is quite distinct from the ordinary Gooseberry Mildew, 


\section{CURRANT AND GOOSEBERRY DISEASES.}

and first appears as a delicate white mildew on the expanding leaf budis, extending later to the young wood and fruit. Later, about May, says the Board of Agricul. ture Leaflet, it becomes visible on the fruit in the form of "glistening, frost-like spots" on the lower and shadly part of the bush, then spreads to the leaves and tender

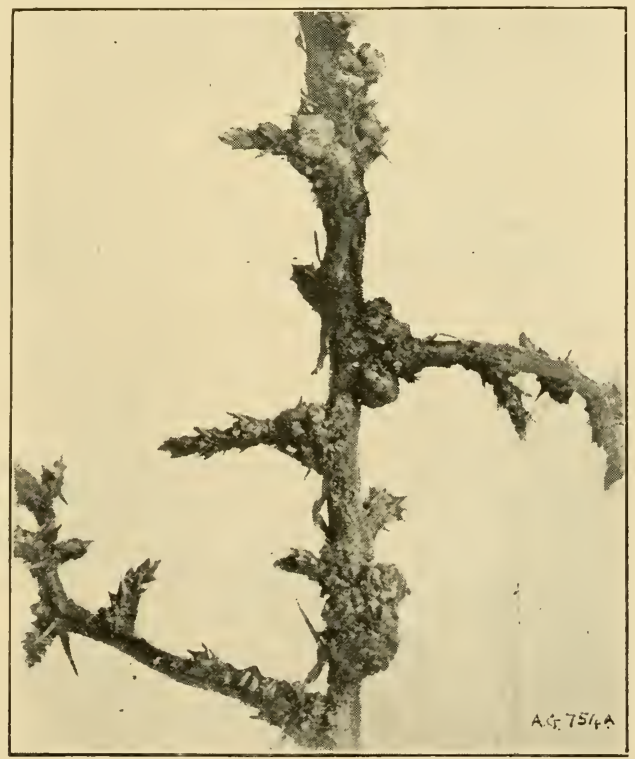

\section{GALLS ON GOOSEBERRY SHOOTS.}

$\mathrm{Mr}$. F. V. Theobald informs that the nodules or exerescences often eeen on gooseberry shoots, as seen in above illustration, are not due to insect attack or dicease, but to suppreseed buds.

shoots. In its earlier stages it has a cobwebby appearance, changing to a light and powdery condition. During the summer spores are developed freely, and are easily conveyed to healthy shoots by the agency of wind, insects, etc. Later still the mildew changes from white to brown, 
and winter fruit, in the form of black dots, are borne thereon, the spores therefrom germinating the following spring and producing the white or summer mildew. The tips of the shoots of infected trees turn brown and shrivel.

Renenies.-The Board of Agriculture and Fisheries, by virtue of the power's rested in them under the Destructive Insects and Pests Acts, 1877 and 1907, have the power to issue ordens for dealing with the disease in any district where its appearance has been detected. See board of Agriculture Order 1910 in Chapter V., Part VI., for further information on this point.

Currant Anthracnose (Gloeosporium ribis). - A fungoid disease which attacks the leaves of the red and white currants in the form of circular brownish spots, and also causes the margins to assume a brownish tinge. Not a very serious disease.

Remenies.-Spray in summer with Formula 23; also gather and burn all fallen leaves in autumin.

Currant Coral spot (Nectria cinnabarina).-The reddish warts often seen on the stems of currants are fungoid growths. The mycelium permeates the tissues of the shoots, and ultimately kills the branch, the red warts afterwards forming on the surface.

Remedr.--Cut off and burn all infected shoots or branches.

Currant Leaf spot (Septoria ribis). - This fungoid disease occasionally does considerable harm to the foliage of the black currant. It attacks the fully-grown leaves in the form of purplish spots on the upper suriace. The mycelium of the fungus ruptures the epridernis, prevents the leaf carrying out its functions, and causes it to decay and fall off early, thus weakening the tree.

Remedes.-(1) Directly spots are seen forming on the surface, spray the foliage with dilute Bordeaux Mixture (Formulie Nos. 20 or 21) or Sulphide of Potassium (For- 
mula No. 23). (2) All fallen leaves should be gathered and burnt.

Gooseberry Black Knot (Plowrightia ribesiæ).According to Teaflet No. 213, published by the Board of Agriculture, the above fungus attacks the stems of the gooseberry and currant, causing first the wilting and yellowing of the leaves, and then the development of
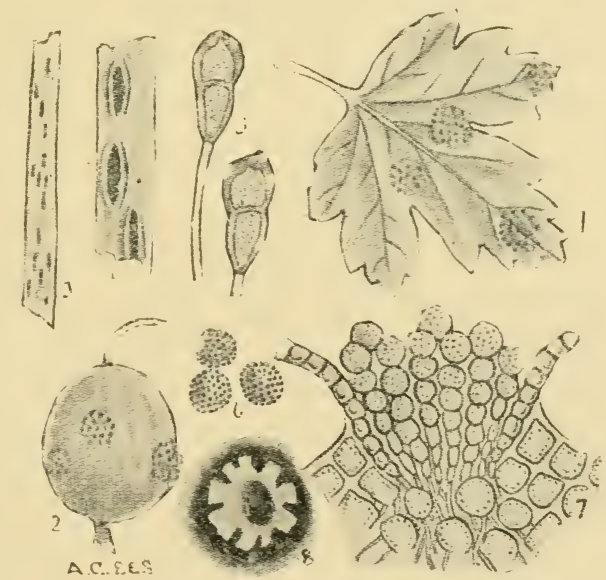

GOOSEBERRY

\section{LEAF CLCSTER CUP DISEASE.}

Fig. 1, Leaf with orange spots thereon; 2, Fruit attacked by the disease. Other fignres sliow the details of the fungus.

(From Board of Agrienlture Leaflet.)

warty nodules, after which the affected branch usually dies. Insect infestation is probably the initial cause, the fungus making an after-attack.

Remeny.--The only one is to cut off and burn all infected growths.

\section{Gooseberry "Die-Back" Disease (Sclero-} tinia or Botrytis).-A fungoid disease which occasionally attacks the gooseberry, causing some of the branches 
to suddenly die when the leaf-buds begin to burst open, or when the flowers appear, or soon after the fruit has formed. The mycelium of the fungus penetrates the tissues of the stems first at the base, and then spreads upwards. Each spring the fungus becomes more active, the bark eventually cracking and displaying fluffy tufts of mould. It appears that the disease also attacks the leaves, causing them to turn yellow at the edges and to fall off. It also spreads to the fruit, causing a browning of the skin, and the eventual rotting of the berry.

Renenes. - Wherever branches die sukdenly or wither, or the leaves turn yellow at the edges, and the berries assume a brown hue, cut out the affected parts and burn them. Indeed, it would be well to burn the whole tree. As a preventive spray with a solution of copper sulphate, 4lb. to 100 gallons of water, just before the burls burst. A further spraying with Bordeaux mixture (Formulie Nos. 20 or 21) as soon as the berries are formed is also recommended.

Gooseberry Leaf Cluster Cup (Ecidium Grossularia).- This disease may easily be recognised. Both leaves and fruit when infested with it are dotted with little round bodies, having white jagged edges and bright orange centres. The latter are the spores, by means of which the fungus is perpetuated.

Remeny.-Remove the infected leaves and fruit, and burn them.

Gooseberry Leaf Mildew (Microsphara Gressularix).--This minute fungus develops on the under surface of the leaves of gooseberries, covering them with a dense white mould. It is not a serious pest, but should nevertheless be got rid of wherever or whenever it appears.

Remeny. - Spray the foliage, when attacked, with a Sulphide of Potassium Solution (No. 23). 


\section{CHAPTER IV.}

\section{FIG PESTS AND DISEASES.}

\section{A.-INSECTS.}

Red Spider and Thrips. - Both pests, more espe. cially the former, infest the foliage of figs grown under glass. In hot seasons Red Spider sometimes attacks the foliage of outdoor figs. These pests are fully described elsewhere in this volume, so that all we need do now is to give the remedies.

Remedes. - Spraying the foliage thoroughly with water or with Formula No. 14, and painting the hot-water pipes with a mixture of flowers of sulphur and milk to throw off sulphurous fumes, generally proves effectual in the case of the Red Spider. The best remedy for Thrips is fumigating with one of the nicotine preparations.

Scales.-Several kinds of scale insects infest the shoots and foliage of the fig. Thus there is the Soft Brown Scale (Lecanium hesperidium), which infests the shoots and leaves of figs grown under glass, and secretes honeydew thereon; the Long Black Scale (Ischnaspis filiformis), which occasionally may be found on indoor figs; also the Camellia Scale (Aspidiotes camellix). All three are capable of inflicting serious injury on indoor figs if allowed to increase to any great extent. They attach themselves firmly to the shoots or leaves, and suck out the sap, thus ultimately bringing the tree into ill-health. Besides, the honeydew secretion they deposit seals up the stomato or breathing pores, and prevents the foliage carrying out its proper functions.

Remedies.-The stems and shoots should be thoroughly cleansed in winter with a solution of Gishurst Compound, 
so as to prevent the scales getting on to the leaves. Spraying during growth with Formula No. 14 will do much to lieep these pests in check.

\section{B. DISEASES.}

Fig Anthracnose (Glasosporium fructigineum).-A fungoid disease which attacks the fruit of the fig, causing them to fall off before they are ripe. It appears in the form of circular groups of pustules of a rose colour. The same disease attacks the fruit of the apple.

Remeny.-Once the disease attacks the fruit the only remedy is to gather and burn them. Spraying with Formula No. 22 might prevent the disease spreading.

Fig Mouid (Botrytis cinera). - This fungus attacks the fruit in the form of a grey mould, and causes it to rot.

Remeny. - The only one is to gather and burn all infected fruits directly they are seen.

Fig Tree Canker (Libertella ulcerata). - A fungoid disease which attacks the bark of fig trees, causing it to crack and canker. It has done serious injury to fig trees in past years.

Rinmenies.-Cut away all diseased tissue, and then paint the wounds with stockholm tar.

\section{CHAPIER V. \\ NUT PESTS.}

Filbert Bud Mite (Eriophyes avellanie). - T'his mite is a near relative of the Currant Bud Mite, and is more prevalent than most people imagine. It is too small to be distinguished by the naked eye. Like the Currant Bud Mite, it is to be found within the scales of the buds of 
the hazel, filbert, and cob-nut. The constant irritation it causes to the scales makes the bud swell abnormally. Wherever the wild hazel grows in the hedges or woodland it is almost impossible to prevent this mite from finding its way to the filbert and cob-nut bushes in cultivated plantations.

Remenies.-The only possible remedies are to cut off the shoots containing the swollen buds, or pull off the swollen buts individually. In both cases burn them as soon as possible, to prevent the mites escaping. See also remarks in connection with the Currant Bud Mite.

Nut-leaf Blister Moth (Lithocolletis coryli). - The larvie of this small and prettily-marked moth are hatehed from eggs laid on the leaves in May. They at once bore into the centre of the leaf, and feed on the soft tissue, leaving the epirlermis intact, but forming white blisters. The larve pupate in the leaves, appear as moths in August, and again lay eggs. In some seasons they do serious injury to the foliage.

Remeny. - Spray in May with Formula No. 10.

Nut-Leaf Weevil (Strophosomus coryli).-This is a tiny weevil, which only measures about one-fifth of an inch in length, is blackish in colour, covered with grey and brownish scales, and occasionally does much harm to the foliage of the filbert and the cob-nut. In some years the weevils appear in considerable numbers during May and June. They are not a very serious pest; hence, where an occasional leaf may be found to be damaged, no notice need be taken of it; but should the foliage be very badly eaten, it is as well to look for the presence of this pest, and to take steps for its eradication.

Remeny. - The best remedy appears to be smearing trays or sheets with treacle or tar, and then shaking the ir:fested branches over them. The weevils, when alarmed, quickly lose hold of the leaves, fall off, and are thus easily caught. 
Nut Weevil (Balaninus nucus).-Filberts and cob-nuts are sometimes found with a maggot inside. These maggots are the larvie of a tiny hrown weevil. The weevils appear from May onwards. The female pierces a hole through the soft shell of the young nuts by means of its jaws, and then deposits an egg which hatches in about ten days. The maggot is white, with a chestmut-coloured head, and furnished with strong black jaws. It feeds on the interior of the nut until fully grown; then gnaws its

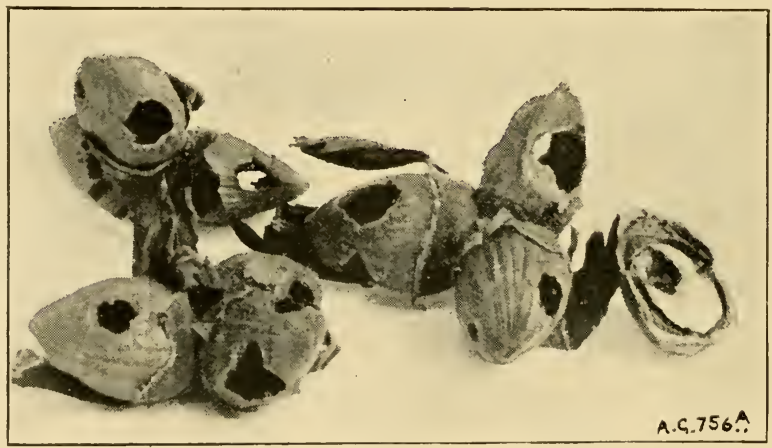

[Thoto: H. I. Smith.

NUTS IXJURED BY SQUIRRELS AND MICE.

In some eeasons both squirrels, rats, and mice do great damage to ripening cobnuts and filberts. The only remedy io to trap them.

way through the shell, escapes, and falls on to the earth, pupates, and changes into the perfect weevil in the spring.

liemedies.-- In the case of these weevils being very prevalent the soil around the base of the bushes should be dressed freely with Apterite, Kilogrub, or Vaporite, in winter or early spring. Moreover, the nuts should be carefully examined, and any showing traces of being infested with the maggot be promptly burnt. Spraying with Formula No. 10 will destroy the weevils.

Walnut Pests. - The foliage of walnuts is sometimes infested with plant lice. Thus the Dusky-reined Walnut 
Louse (Ptychodes juglandis) infests the upper sides of the leaves, and the Common Walnut Louse (Pterocallis juglandicoli) the under sides of the leaves, both sucking out the sap and crippling the growth. The Walnut Leaf-Gall Mite (Eriophyes triseriatus erinea) also causes bladklerlike swellings on the leaves.

Remedes. - Spray for the Aphis with Formula No. 14. For the latter there is no remedy except to pick off and burn infested leaves.

Other Pests.-The Trinter, Mottled Umber, and Buff-tip Moth larve; Aphis, and Leaf Weevils attack the filbert and cob-nut; the Woorl Leopard Moth larva the walnut.

\section{CHAPTER VI.}

\section{PEACH AND NECTARINE PESTS.}

\section{A._INSECTS.}

Peach scale (Lecanium Persica). - Another species of scale insect, siruilar in form to the Mussel and cther Scales previously describul. The perfect female wingless insect is oval in shape, brownish in colour, with a stripe down its back and a pale margin. The male has wings. When it reaches maturity the female insect beneath the scaly ecvering dies, and its place is taken by a cluster of eggs. In spring the eggs give birth to larve, which wander over the shoots till they find a suitable spot; then they pierce the epidermis with their beaks and suck out the sap. Here they remain till they lay eggrs, then die.

Remedies.-Spraying the tree with a Kerosene Emulsion (Formula 16) or with Formula No. 1 when the leares are off are the most efficacious remedies. All leaves shouls? be burnt when they fall off. 
Other Pest8. - Thrips, Aphides, and Red Spider are fairly common enemies of the peach and nectarine. See notes elsewhere on these pests.

\section{B.-PEACH AND NECTARINE DISEASES.}

Peach-Leaf Curl (Exoascus deformans).-This is a fungoid disease which hardly ever attacks trees grown ander glass, but often does trees grown outdoors in cold districts, and especially in cold, changeable springs. For this reason peaches and nectarines should always have the warmest and most sheltered wall in the garden. There are two kinds of peach curl or blister, cne caused by a

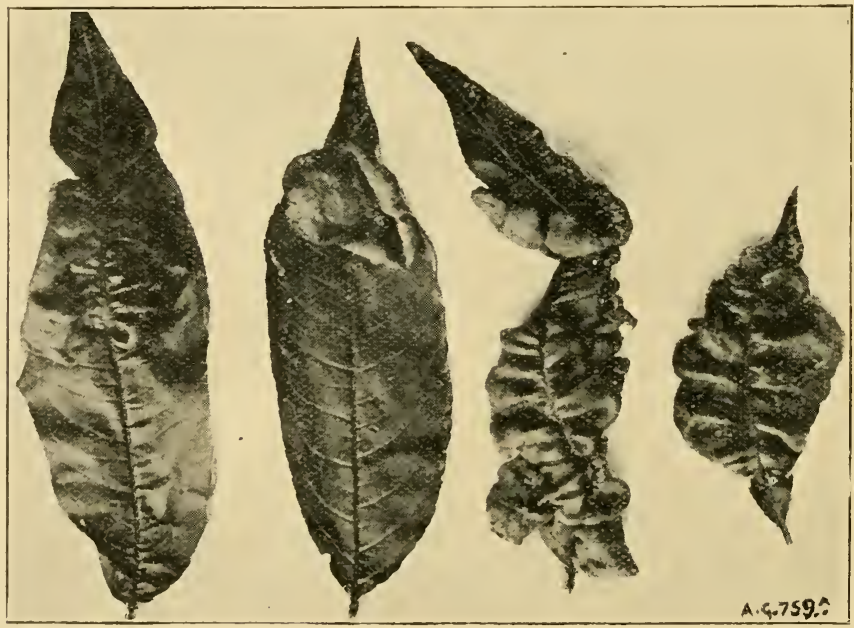

[Photo: E. A. Smith.

PEACH LEAF-CURL FUNGUS (EXOASCUS DEFORMAN-).

It canses the young leaves to become puckered and distorted.

fungus and the other by Aphicles. That caused by the above fungus has its leaves thickened and swollen, and covered by a whitish-green mould or bloom, something 
like Mildew, and which is chietly apparent on the lower surface. The infected leaves die off early, and, of course, the tree suffers loss by so much: also whilst the leaves last they cannot perform their proper functions. The fungus also seems to spread into the branches, and to again reappear on the same branch and its branchlets another season.

Remines.-(1) There is no remedy except to remove infested leaves and bum them an soon as discovered, and in very bard cases to cut off and burn the whole branch. Spraying the foliage early in the season with a mixture of sulphide of potassium (liver of sulphur) and water (Formula No. 23) is a good preventive. (2) Another excellent remerly is to spray the tree, before the leaves appcar, with Bordeaux Mixture (Fomula Nos. 20 and 21), the operation beingr repeated a few weeks later.

Shot-Hole Fungus (Cercospora circumcisa).--This fungus is responsible for the formation of the shot-like holes sometimes seen in the leaves of the peach, cherry, etc. The disease causes circular patches in the leaf to turn brown, dry, and eventually fall out, leaving holes. Needless to add, this injury seriously affects the natural functions of the leaves, and the result is unhealthy growth.

Remeny. - Spray with Carbonate of Copper and Ammonia Solution (Formula No. 22) when the leaves begin to expani, and at intervals afterwards.

Silver-Leaf Disease.-See chapter on "Plum Diseases."

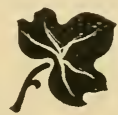




\section{CHAPTER VII.}

\section{PEAR PESTS.}

\section{A.-INSECTS.}

Pear-Leaf Blister Mite (Eriophyes pyri).-Th". leaves of pear trees are sometimes covered with blister. like spots, slightly raised upon the upper and under surfacers. These spots are red or green in the earlier stages of their formation, and black or brown later on. To distinguish between these blisters and the scabs formed by the P'ear Scab fungus cut one of the blisters open and examine it with a magnifying-glass. If within are seen a number of small mites, then it may be taken for granted that the leaf is infested with the Pear-leaf Blister Mite. The mites live within the scales of the leaf-buds during the winter; early in spring they cone forth, puncture the epidermis of the leaves, and deposit within their eggs. When the young are hatched they come forth, pierce the epidermis, and lay more eggis; and so the process goes on: of egg-laying and covering the entire surface of the leaves with minute gills.

Rementes. - Spraying the pear tress in February with Formulie Nos. 1 or 8 is one of the best remedies, as this will destroy the mites ensconced in the scales of the burls, and revent them coming forth in the spring and depositing their eggs in the leaves. Fallen leaves should, as far as possible, be raked up and burnt.

Pear-Leaf Blister Moth (Cemiostoma scitella).-A minute moth, the parent of small pale-green caterpillars, which feed on the soft tissues of the leaves of pears, apples, and cherries during summer, and cause dark brown 
blisters to form, which hinder the development of the tree. There are two broods, one appearing in June and July and the other in autumn.

Remsnes.- (1) Spray the foliage in Jume with Soft Soap and Quassia (No. 14) or a Kerosene Emulsion (No. 16), to prevent the moth laving its eggs. liepeat in September. (2) Spray with Paris Green (No. 11) directly the blossoms fall. (3) Gather up and burn all fallen leaves.

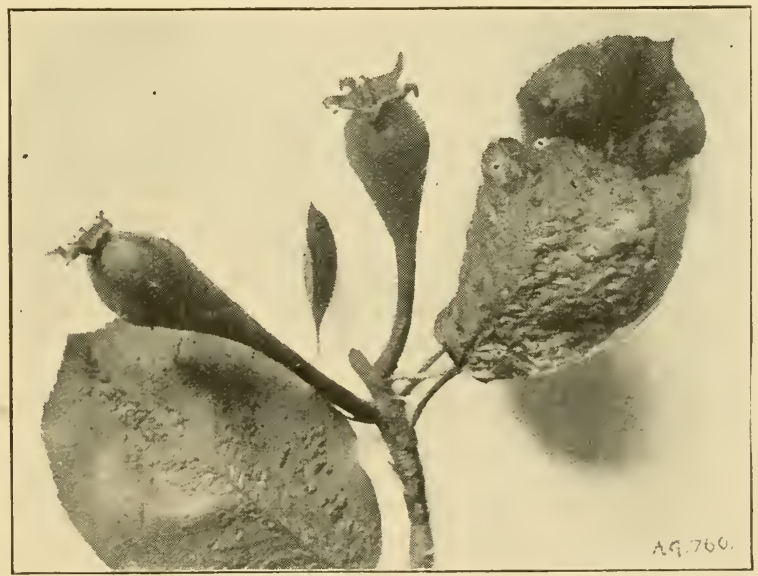

[1 hoto: H. 1. - mith.

PEIR LEITES ATTACKED BY THE BLITER MITE. lyri).

The leaves have been badly blistered by the Pear-leaf Blister Mite (Eriophyes

(1) Dress the soil with Apterite, Kilogrub, or Vaporite in autumn.

Pear Midge (Diplosis pyrirora).-This insect is the cause of the formation of distorted fruits when in an early stage of development. The fly measures one-tenth of an inch in length, las a blackish-grey body covered with yellow or white hairs, and grey wings. The fentale is larger than the male. She is provided with a long tube, 
or ovipasitor, which she uses for depositing the eggs. She appears in April or May, and lays her long, tramsparent white eggs in the opened or unopened blossoms. In six days the eggs hatch, and the small yellowish-white, brown-headed larve at once commence to feed on the embryo fruit, each of which contains a score and upwards of the maggots. By June most of the larve are fully developed, and they either make their escape from the fruit still on the branches or when it has fallen to the ground, and then burrow an inch or so into the soil and ferm silk cocoons. The larve are said to jump from the fruit to the ground. Some of the larva do not pupate till the following spring, while others do so almost at once. Unfortunately, it is not possible to detect the presence of the maggots in the embryo fruit at first. It is not tili later that the unequal development of the fruit indicates their presence. If a fruit be then cut open the interior will be found hollow and black, and full of the maggots. Generally, infested fruits begin to swell much earlier than those not attacked.

Renenies.-In the case of dwarf trees every abnormâllydeveloped fruit should be picked off and burnt. If fallen fruits are found on the ground, and these contain maggots, burn them at once. Where trees have been badly attacked the previous season, and there are evident signs of the crop again being attacked, it is advised that the trees should be sprayed with Arsenate of Lead (No. 10), so as to kill the fruit and starve the larve. Dressing arable or pastural orchards with kainit at the rate of five to ten cwts. per acre early in June, when the larva are begimning to fall from the fruits, is also strongly re commended. Forking Strawson's Vaporite, or Apterite or Kilogrub, into the soil at the rate of one ounce per square yard early in June is sair to kill the mirlges as they emerge from the earth.

Social Pear Sawfly (Pamphilus flaviventris).-The larve of this Sawfly spin webs on the foliage of the pear, 
plum, and cherry trees, and live in communities therein. They measure about half an inch to an inch in length, and are of a reddish or a reddish-orange colour, smooth shining, and somewhat cylindrical in shape. The female Sawfly lays her eggs on the inside of the pear leaves, towards the end of May. The caterpillars hatch out in a few days,

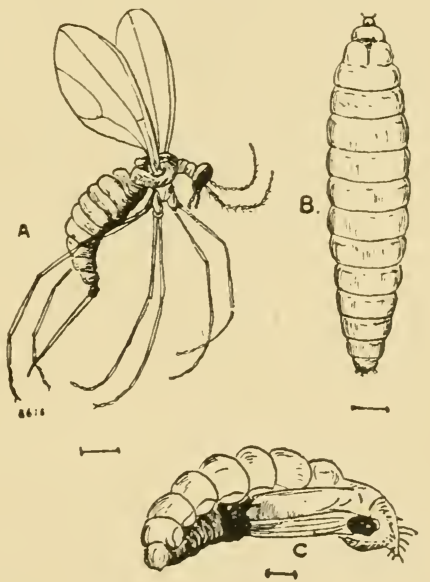

PEAR MIDGE (DIPLOSIS PYRIYORA).

$A$, the Midge or Gnat with line below to indicate its natural size; $B$, the grub with line to show ite natural length; C. chrysalie.

and then start to spin the web, already described, round and over the foliage, and, secure in this habitation, commence to devour the leaves. When fully grown they let themselves down to the ground, boring into the earth some four inches or more deep, and then enter into the pupal state. Here they remain until the following April or May, then emerge as Sawflies.

Remedies.-As it is very difficult to reach the larvæ ensconced within the webs by means of insecticides, the best plan is to pull off all the webs and contents by night and immediately destroy them. Where this cannot be 

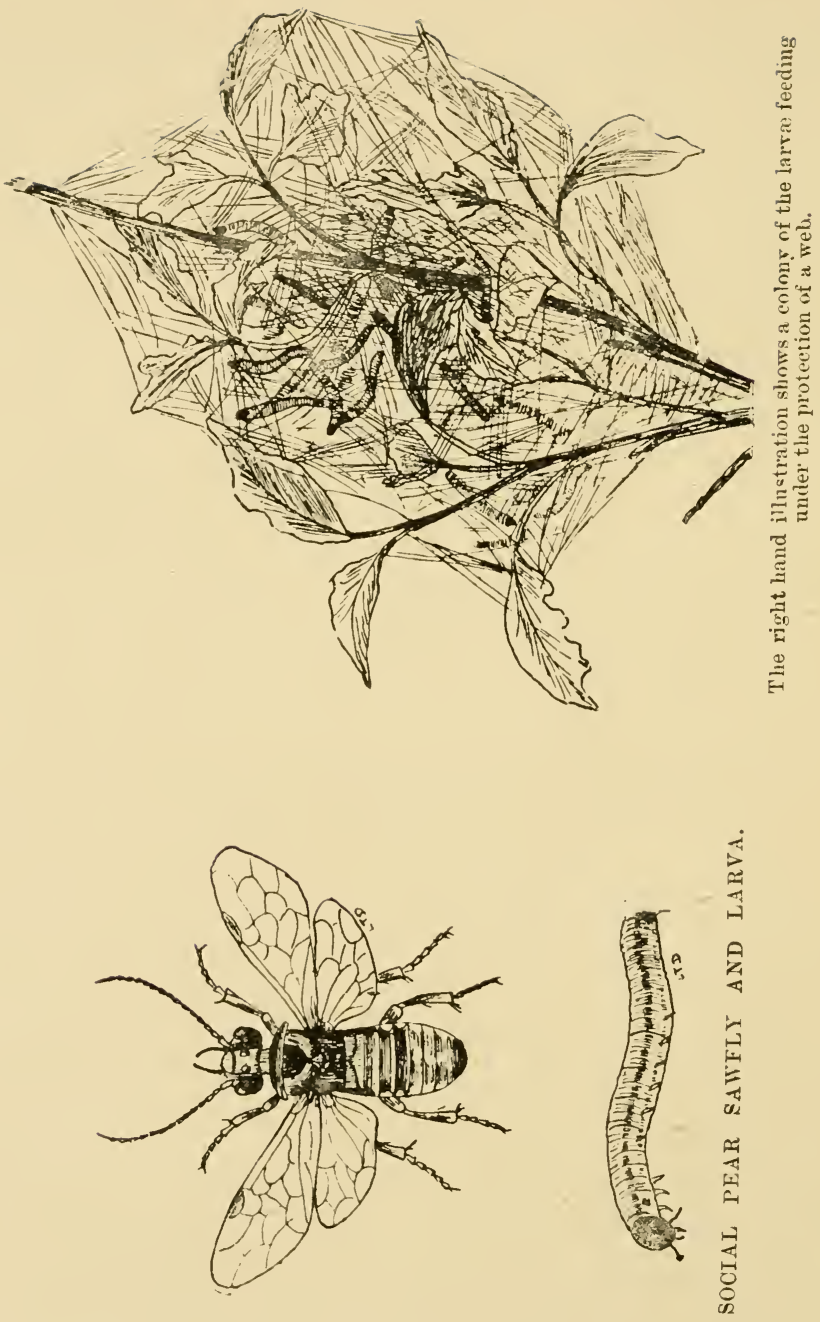
done, spray the infested trees thoroughly with a Kerosene (No. 16) or P'aris Green (No. 11) Solution.

Vapourer Moth (Mrgyia antiqua).-Caterpillars of this moth feed extensively on the foliage of the apple and pair. They are easily distinguished from other caterpillars by their gay appearance. The adult larva measures one and a-quarter to two inches long when full grown. It

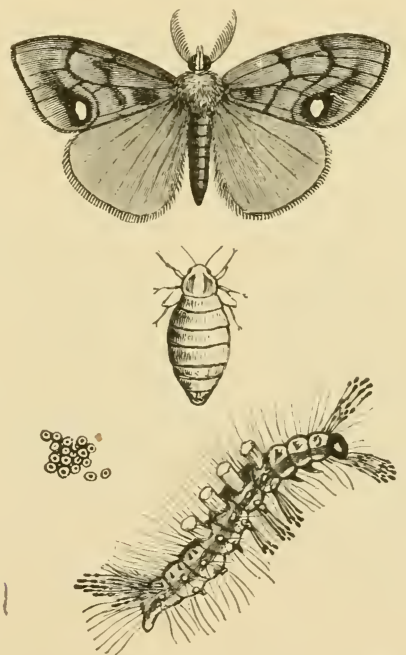

VATOLTER MOTH (ORGYIA ANTIQUA).

Upper figure, male moth; middle one, wingless female; lower one, caterpiliar, with group of egge on the left.

is dark grey in colour, and spotted with small grey tubercles. On its back are four large brownish hairs. When the caterpillars are fully developed they pupate in the remains of leaves or on the stems or shoots of the trees in which they have been feeding. They remain in the pupal stage about a fortnight, then appear as perfect moths. 
Renedies - (1) Spray the foliage with Paris Green (No. 11), or (quassia, or Kerosene Emulsions (No. 16), when the caterpillar's are seen. (*) A careful search also should be made among the branches for the cocoons, and these should be cut off and destroyed.

Note.--See also the chapter on "Apple Pests."

Other Pests. - The larvie of the Large Tortoiseshell, Wood Leopard, Goat, Lackey, Winter, Mottled Umber,

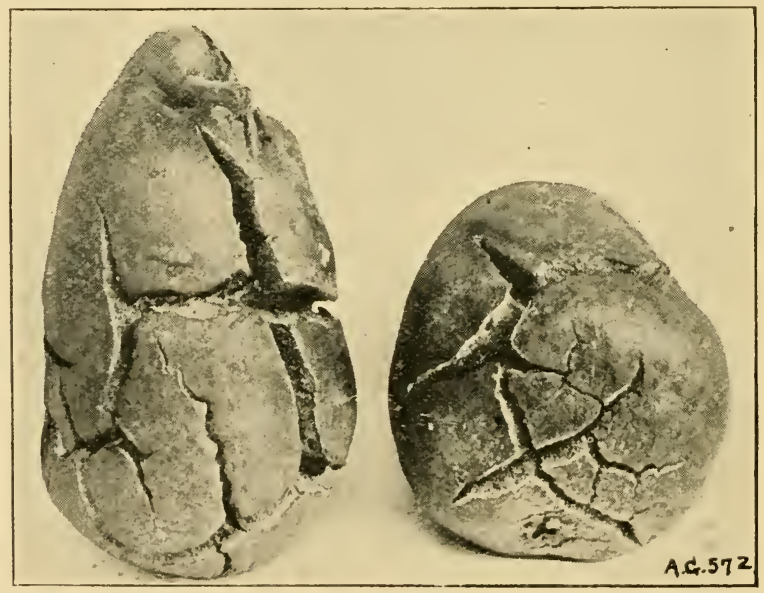

[Photo: H. A. Smith.

BADLY-CRICKKD PE.IRS.

The fruit in an earier stage was attacked by the Pear sab Fungus, with the result that later on it became badly cracked.

and Codling Moths; Fruit Bark Beetle, Apple Blossom IVervil, Leaf Weerils, Ipple Sawtly, Apple Aphis, and Mussel Scale also infest the pear. See "Apple Pests."

\section{B.-DISEASES.}

Pear-Leaf Blister (Exoascus bullatus). - The blisters or swollen lumps sometimes formed on pear leaves are caused by a fungus. At first they are green, then become 
more or less brown, and finally whitish. The blisters will be found on the under surface.

Pemeny.--Spraying the foliage with Bordeaux Mixture (Formulie 20 or 21) in the early stages of its growth will prevent the disease spreading. Gather and burn all fallen leaves when possible.

Pear-leaf Cluster Cups (Roestelia cancellata).A fungus of a parasitical nature, which produces rugged swellings on the leaves of the pear. The fungi seen on the upper sides are flask-shaped, pale brown, and produced in clusters. On the opposite sicle are orange or reddish spots containing black dots.

Remedr.-Pick off and burn the infected leaves. The disease is not of a serious nature.

Pear scab (Fusicladium pirinum). - There seems to be a doubt in the minds of some mycologists as to whether this fungus is not the same as that which produces the Apple Scab. Anyway, it produces similar results on the fruit of the pear, and the same precautions and remedies should be adopted to guard against its attacking pear leaves and fruit.

\section{CHAPTER VIII. \\ PLUM PESTS.}

\section{A._INSECTS.}

Plum Aphides.-The Plum Aphis (Aphis pruni) and the Clearwing Aphis (Hyalopterus pruni) are both injurious to the foliage of the plum and damson. The former are green or olive-brown in colour, and covered with a mealy powder. The latter are bluish-green, and also covered with mealy powrler. Both infest the young 
shoots and leaves, and cause them to curl. If allowed to increase they seriously aripple the growth of the tree and spoil the fruit.

likmenes.-(1) lorectly an infestation is discovered sprat the tree thomoughly with a Soft sioals and Quatsia (No. 14) or a Kerosene Emmlsion! (No. 16). (2) ( 'ut off and burn the points of badly-infested shoots. (3) spray in Jamuary with a limp-salt wash (No. (1).

Plum Sawfy (Hoplocampa fulvicornis).- Fortmately this pest is not a very common one, although where it

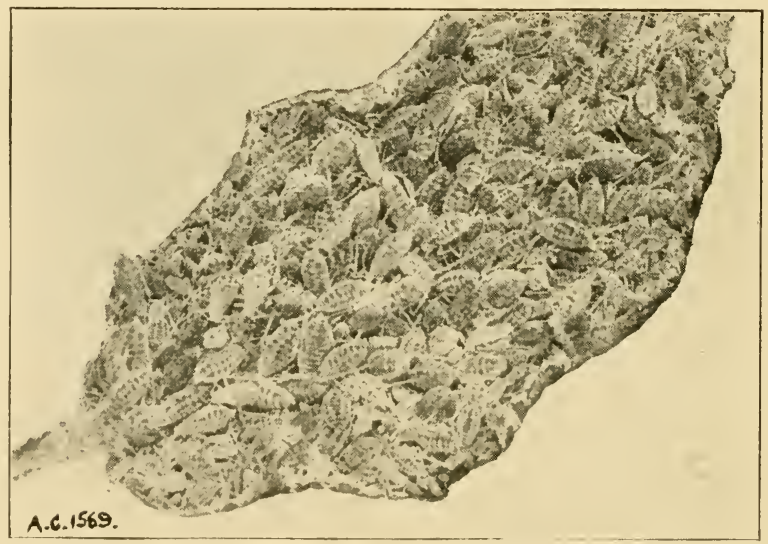

[l'hoto: J. G. Blakey.

\section{COLONY OF PLUAI APHIS.}

The Plum Iphis (Iphis prumi) is a very serions pest in some seasons. attacking both plums and damsone, and calsing the leaves to curl.

has made its appearance in this comtry it has done a great deal of harm. The female sawfly makes a slit in the calyx of the flower, and deposits one eggr therein. In a week to a fortnight the caterpillar hatches, and eats its way into the interior of the young fruit. Here it consumes the (mobryo kernel, causing the plum to fall. As soon as the fruit reaches the ground the larva creeps out 
and buries itself in the ground, where it remains in the larval state till spring; then changes into a pupa, emerging as a perfect Sawfiy at the time the blossoms of the plum begin to open.

Remenies. - All plums that fall carly from the trees should be picked up as soon as posisible and burnt, before the larva can escape from them into the earth. Dig in, where possible, a soil fumigant to asphyxiate the pupa. Do this in autumn.

Plum Weevil (Otiorhynchus tenbricosus).-This black, shiny weevil, measuring about half an inch in l ngth, does a great deal of injury sometimes to the foliage of plums, raspberries, strawherries, and other fruit trees, more especially in Kent. The weevils strip the shoots of their leaves, destroy the buds, and also attack the bark. The eggs are laid in the ground during the summer, and grubs hatch from these in August and September, and then commence to feed upon roots of any crops that may be in the vicinity.

Reventer.-1)ress the soil for some distance around the trees, in autumn, with a soil fumigant.

Red Pium Maggot (Opadea funebrana). - The larr: of this moth feed on the interior of the fruit, and may often be found in ripe fruits. The moth is a small one, and it lays its eggs on the stalk of the fruit in June and Juiy. The larva, when hatched, enter the fruit near the stalk, and feed on the flesh around the stone till they reach maturity; then they escape and winter in crevices of the wall, etc.

Remenies. - Gather and burn infesterl fruits, and seareh for the pupie hiding in shreds, crevices, etc.

Wasps. - The Wasp (Vespa vulgaris) is very partial to ripening fruits in the garden and orchard.

Rementes.-(1) Find out their nests, and late in the evening saturate cottonwool with cyanide of potassium, thrust this into the nests, and seal up tightly with soil. 
(2) Slightly damping gumpowder, rolling it in paper to form a squib, adding a little dry powier at one end, thrusting the opposite end in the nest, setting it alight, and then digging out the nest.

(3) Pushing rags saturated with paraffin oil into the nests and setting these alight at night. (4) Hanging wide-monthed jars partly filled with treacle and water, or stale beer and sugar, near ripe fruit cutcloors or bunches of grapes indoors; the wasps will be allured to taste this, and be drowned.

Other Pesta.--In addition to the foregoing pests, several others attack the plum, as the Winter, March, and Vapourer Moths, Cherry Sawfly, Pear Lyda, shot Borer Beetle, Goat and Leopard Moth, Fruit Trew Bark Beetle, and Mused Scale. These are described in the chapter on "Apple Pests," which see.

\section{B. DISEASES.}

Bladder-Plum Disease (Exoascus pruni).--This is a fumgoid disease which attacks the fruit of the plum and damson. The mycelium of the fungus finds its way to the ovary of the flower, and the young fruit, instead of developing in the normal way, forms a bladder-like object, stoneless and hollow within, and with a wrinkled, warty exterior. In due course, the fruit of the fungus appears as a white bloom on the surface. Once a tree bears these abnormal fruits it is likely to eontinue to rlo so, since the nucelium permanently resides in the shoots near the point of new growths.

Reveny. - The application of fungicides is useless. The only thing that can be done is to cut away the shoots which have borne the diseased phums a foot or more back, and to burn them. All diseased fruit should be promptly gathered and burnt.

Plum Gummosis (Cladiosporium epiphyllum).Plum, cherry, apricot, and peach trees are sometimes at- 
tacked by what is called the "Gumming Disease." Its presence is indicated by globular masses of colourless gumi oozing out of the bark of the trumk and branches. These masses are usually of a soft texture in damp weather and hard in dry weather. It appears that this disease is the result of a fungus gaining an entrance to the tissues by means of wounds in the bark, or such as would be formed by pruning. When badly attacked the branch often dies or becomes very unhealthy.

Rinmenies.-- In the case of a bad attack the only course is to burn the tree. Where only slightly attacked cut away the diseased parts and paint the wounds with Stockholm tar. Mr. George Massee recommends that the soil around the tree be dressed with quicklime to destroy the conidia stage of the fungus, which has been washerl down from the gum masses by rain.

Plum-Leaf Blister (Polystigma rubrum).--A fungoid disease which attacks the under sides of plum leaves, forming reddish patches studded with dark dots. If very prevalent it arrests the development of leares and fruit.

liemedy.-Collect and burn the fallen leaves in autumn.

Silver-Leaf Disease (Stereum purpureum).-A modern disease which has attacked the foliage of plums, cherries, peaches, and Portugal lamels very seriously during the last few years. As yet its life history is not fully understood. It causes the leaves to assume a silvery hue on their upper surface and a yellowish tint underneath. In a recent report of the Woburn Fxperimental Fruit Farms it is stated that trees could be inoculated at any time from January to July with minute particles of the fungus, in root, stem, or branch, but most effectively in stem. Other experiments showed that the disease is not spread from affected to healthy trees by the operations of pruning or cultivation, as it does not run from one tree to its immediate neighbour, nor does it spread in the direction in which it would have been car- 
ried by the pruning-knife or implements. Everything points to the infection being generally conveyed by airborne spores of the fungus gaining an entry into healthy trees through some chance wound. Apparently only in very exceptional cases ro trees recover after being once attacked, and the experimenters have no remedy to offer so far. It may here be mentioned, though, that $\mathrm{Mr}$. 1)uncan, of Canterbury, reports that: "Having made a hole in the earth, about four inches in depth and a yard in diameter, around the trunk of the tree, he sprinkled one pound of the ordinary, or commercial, sulphate of iron into it, and covered first with a layer of rotted manure and then with earth. The tree was treated late in November after the sap had ceased to flow, and the spring rains dissolving the dressing carried it in solution to the roots before growth recommenced. The experiment proved successful, as the tree bore well for two seasons, and has since showed no traces of the disease."

\section{CHAPTER IX.}

\section{RASPBERRY AND STRAWBERRY PESTS.}

\section{A. INSECTS.}

Raspberry Aphis (Niphonophora rubi). - This Aphis attacks the raspbory and blatkberry, congregating on the under surface of the leaves, sucking out the sap, and causing them to curl. Another Aphis-siphonophora chelidonii-is ardicterl to the same fault, and both in some seasons do serious injury.

Remeny. - Spray the canes with Quassia and Soft Soap (Fomula No. 14) directly the pest is observed on the foliage. 
Raspberry Beetle (Byturus tomentosus).--The Raspberry Beetle is a small insect, rarely exceeding onesixth of an inch in length. It gains its specific name of tomentosus from the grey or yellowish down with which it is so thickly clothed, and which forms so dense a covering as to conceal the real colour of the insect's body. The actual colouring of the beetle varies considerably through many shardes of brown, from a yellowish tint to quite a deep pitchy colour. The slightly-clubbed antenna and the
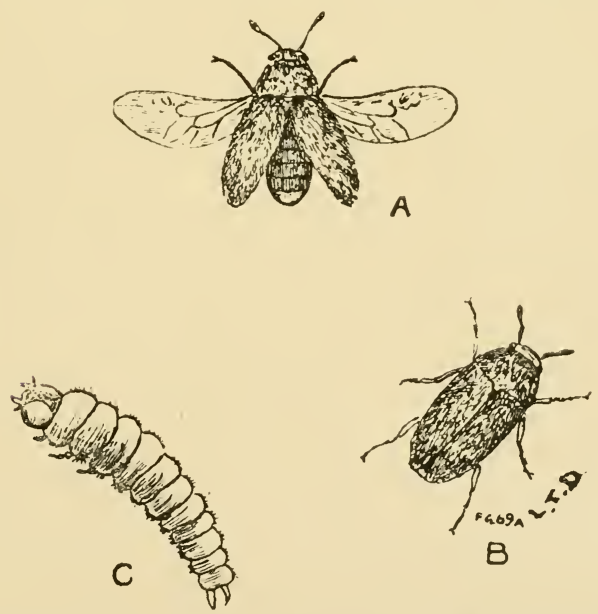

RASPBERRY BEETLE (BYTLRLS TOMENTOSL'S).

$A$, beetlo flying; $B$, at rest; C, larva; all magnified.

leg of the beetle are a ruddy yellow colour, and for its size the little insect has a comparatively large pair of forewings, which are folded away under the wing-cases when the beetle is at rest. When full-grown the larva of the Raspberry Beetle measure from five-eighths of an inch to one-quarter of an inch in length. Their bodies are cylindrical, slightly flattened in front, the posterior extremity ending in two brown, curved points, beneath which 
is a tubercle used as a pro-leg. The gencral colour of the larvie is yellowish, with the back a deeper and more brownish-yellow tint, and the head brown. The true legs of the larve are six in number, and are fairly long and hairy. After passing the winter months as hibernating pupa, the beetles make their first appearance about the middle of April or beginning of May, the exact date varying with the climatic conditions of the season, a cold spring always retarding their final metamorphosis. (On emerging from their pupre cases the beetles betake themselves to various flowers, particularly those of the Raspberry, attacking both the fully-expanded blossoms and the unopened flower-burds, piercing a hole and eating their way right into the latter, and greedily devouring the stamens and petals of the mopened blossoms. Is these bectles are present on the raspberry canes the whole time they are in flower, very few of the blossoms, if any, cscape injur, ; whle the resulting fruit from those flower: which escape the depredations of the perfect beetle fall a prey to its hungry larve. Towards the middle or enil of the flowering time of the raspberry canes the female beetle deposits her eggs on or near the blcssoms, and the larvar, on hatching from the eggs, at once enter the roung fruit, on which they feed. With the ripening of the fruit the larval stage of the beetle's existence comes to an cinil. and the now full-grown and full-fed larva quits the ruincel fruit, and, seeking some cosy, sheltered erack or cramly in the stem or bark of the raspberry, forms a cocoon in which to pass the pupal state of its life, which lasts throughout the winter months.

Remenes. - The best method of combating this pest at present linown is to spreat old sacks and cloths smeared with a sticky paste of soft snap and parafinin, or tar, under the bushes on dull and chilly days, and then to carcululy shake the branches, so that the hectl is will fall cul to the sticky cloths. It is most important that these operations should only be carried out during dull, cloudy weather. when the beetles are somewhat torpid and sluggish in 


\section{RASPBERRY AIND STRAWBERRY PESTS.}

their movements; as the little insects are very much on the alert on fine, sunny days, taking to flight on the least movement of the bushes. Frequent spraying with some wash, like No. 16, which would render the unopened flower-buds unpalatable to the beetles, would, no doubt, if carried out regularly and quite early in the season, save the blossoms to a certain extent. Nuch may be done to prevent a recurrence of this most destructive infestation by clearing away and burning all old wood from the bushes, and any twigs and leaves near them on the ground, that might afford harbourage for the pupe.

Raspbezry Gall FIy (Lasioptera rubi).-A gall midge, the larvie of which bore into the epidermis of the shoots and cause galls, or swellings, to form. The female millge lays its eggs at the base of the shoots or buds in early summer.

liemeur.-All shoots furnished with galls or swollen parts should be cut off and burnt.

Raspberry Math (Lampronia rubiella). - The larvie of this small moth is responsible for doing a great deal of injury to the :hoots of raspberry canes in some districts. The moth itself appears at the end of May and in June, and lays its eggis upon the flowers of the raspberry. In about a week's time caterpillar's are hatched, about onequarter of an inch long, and of a pinkish or reddish colour with a black head. The caterpillar soon leaves its floral nest by crawling or letting itself down by silken cords to the earth beneath the canes, and hibernates in a silken cocoon during the winter. Early in A pril the larva leaves the cocoon, crawls up the canes to the nearest bud, gnaws its way through this into the pith of the cane, and then starts to feed voraciously upon it. In consequence of this attack the canes refuse to put forth healthy leaves or to bear fruit, and speedily wither and die.

Remedes. - Is the caterpillars hibernate in the soil around the base of the raspberry canes, the soil should be dressed with soot or lime in early winter and then 
forked in. All cintes which show signs of refusing to develop healthy leaves or blessoms, and are inclined to shrivel, should at once be cut off and burnt, to prevent the larve escaping. Spray with a lierosene Emulsion (Formula No. 16) just before the buds burst.

Raspberry Sawfly (Emphytus cinctus). - The larve of this sawfly bore their way into the pith of raspluery canes and feed upon it, causing the shrivelling or death of the canes. The grub is of a pale green hue, and about lalf an inch long. There are two broods, and the eggs are usually deposited on the under sides of the leaves.

Remevies.--Spray in autumn with Arsenate of Lear (Fommla No. 10), and cut off and burn any canes containing the grubs.

Raspberry Weevil (Otiorhynchus picipes).-This weevil feeds upon the leaves of raspberries am strawberries, as well as many other plants and trees; and, as it carries on its operations during the night and hides away in crevices or in clods of earth by day, it is not always recognised. The weevil measures about one-third of an inch in length, has a peach-coloured head and thorax, and body of a clayey colour. The weevil lays its eggs in summer in the earth, and in due course larve of a white or yellowish-white colour appear. These are legless. They feed mainly upon the roots of crops, and are sometimes specially destructive to the roots of strawberries. It is, however, with the weevil that we are chiefly concerned here.

Rementes.-Being a nocturnal feeder, the Raspberry ITeevil camnot be discovered by day; consequently, any remedies adopted for its eradication must be carried out at night when the insects are actively engaged in feeding. If the foliage of rasplacries is found to be very badly eaten, and 110 insects found doing the mischief by day, it may safely by concluded that weevils are the authors 
of the mischief. At night, therefore, get trays or something similar sineared with tar or treacle, and go quietly along the rows and shake the shoots over these. The weevils will immediately fall off, and be easily trapped on the tar. 1)ressings of kainit or of a soil fumigant in the antumn, as well as constant hoeings during May and June when the weevils are active, will help to reduce the number of these pests. Some have tried saturating ashes with paraffin at the rate of four to five pints per bushel, and sprinkling this mixture on the surface of the soil around plants, and it has proved successful in destroving the weevils.

Strawberry Aphis (Niphonophora fragariella)._- I form of plant lice which has been found doing considerable harm to the foliage of strawberries in some parts. The ora is deposited on the under sides of the leaves in antumn, and these give birth in spring to viviparous females. The lice infest the flower stems and trusses, as well as the leaves, and severely cripple the growth ambl (rops.

Remedes. - Trim off and burn the old leaves in antumn, and in spring spray with Soft Soap and Quassia Solution (Formula No. 14).

Strawberry Eelworm (Aphelenchus fragarice).A microscopic worm which lives and reproduces itself in the cellular tissue of the leaves and buds, causing both to become distorted and deformed. Owing to its causing the growth to become congested and condensed into at mass, its has been named the "Caulifower l)isease." The Root Eelworm, described elsewhere, also attacks the roots, causing them to rot.

Remeny. - The only one appears to be to burn the infesterl plants.

Strawberry-Leaf Button Moth (Perollea comariana).-The larve of this moth feed during May and 
Jume on the leaver and flowers of the strawberry. They have pale yellow heads, spotted with brown on each sule, and green bodies. Fortmately, this pest is not very prevalent.

liemenr. - The only remedy known, so far, is a preventive one, and that is to eollect all the dearl foliage and mbbish between the plants and burn it, in order that the larve or pupe hiding therein may be destroyed.

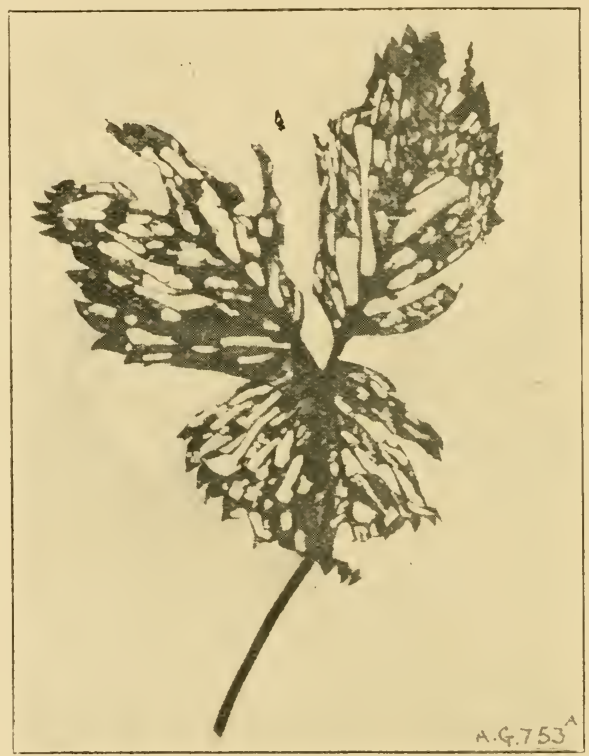

[Plicto: H. 1. mi: mis.

STR.IWEERHY L.E.IF EATEX BY SXIHL.

slugs and snaile are partial to the leaves of strawberries, more expecially the strawbery snail.

Strawberry Snail (Helix rufescens).-- A smail with a yellowish-brown borly, striperl with diak hrown, and having a pale grey shell, which attacks both leares and 
fruit, especially in noist weather. They feed chiefly at night. 'This, in company with other' slugs and snails, often do selioui injury to the strawbery crop.

liemeries.--1) listing with soot after the fruit has set, or iressing with a soil fumigant in winter to kill the ova, are LO0.1 remedies.

Other Pests:-The larve of the Heart and Dart, Garken Sirt, and Large White Plume Moths attack strawberis. Various beetles and weevils also levy a tribute on the foliage and fruit. Then the larvie of the Dot, Buff Arher, and Garden Swift Moths are partial to the raspberry. Wrevils and bectles may occasionally do injury. Those described in detail are, however, the worst offender's.

\section{B. DISEASES.}

Raspberry Spot (Gluosporimm venetum).-A disratse which attacks the roung canes and leaves of the raspberry. It first appears as small red spots, which incruas in size and form large blotches. The effects of the disease are not always apparent the first season, but the next the cancs produce a poor crop of fruit and scanty foliage.

likmenes. - (1) Canes barlly attacked are better cut off and burint. (2) When the disease is slight, spray the canes in winter with a Sulphate of Iron solution.

Strawberry Leaf Spot (Sphrerella fragarix). - This disease appear's on the leares of the strawberry in the form of dark spots, which afterwards have a greyish centro, edged with red. It spreads very rapidly, and completely disorganises the tissues and functions of the leares, wealiening the plants and spoiling the fruit.

limanes.-.- Spraying the plantis with Bordeaux Mixture (Formula 20 or 21) when the new leaves form, and cutting off and burning all infected leaves are the only remedies. 
Strawberry Mildew (Splielothe'a humuli).-A fungus which attaclis the hop, as well as the strawberry. It causes the leaves to curl in the first instance, and then the mycelium appears on the muler surface as a white mould. The fruit also is attacked. Sudden changes of temperature are favourable to the appearance of the mildew on outdoor and indoor crops.

Remeur.-Directly the leaves begin to curl spray the plants with Formulae Nos. '20 or 23.

\section{CHAPTER X. \\ TOMATO PESTS.}

\section{A.-_INSECTS.}

Eelworm, or Root Knot Disease. - The roots of tomatoes and cucumber's are occasionally infested by a microscopic animal called the Eelworm. The latter are very small, translucent ereatures, measuring about 1-75 of an inch in length. 'They are hatched from eggs present in the soil, from whence they bore into the roots of tomatoes and cucumbers, gain admission to the cells, which they rupture, and thus cause linots or swellings to form on both the large and small roots. The effect of this disorganisation of the cellular tissue is the gradual wilting and total collapse of the plant. The Eelworm in question is known as Heterodera radicicola.

liementes.-Burn any plants attacked. Saturate the intended compost before using three times, at intervals of a fortnight, with a solution of one part of carbolic acid to twenty parts of water. Do not use compcist so treated until an interval of six weelis has elapsed. Or, mix Vaporite or Kilogrub with the compost a few weeks before using. Clear out infested soil, and treat as advised for new compost before using it elsewhere. Spray the beds, 
Walls, and floors with a solution of one part carbolic acid to eight parts of water.

Greenfy.-Fumigate with nicotine to get rid of this pest.

Red spider.-This mite, which is fully dealt with elsewhere, also attacks the foliage of tomatoes where the atmosphere is kept too dry.

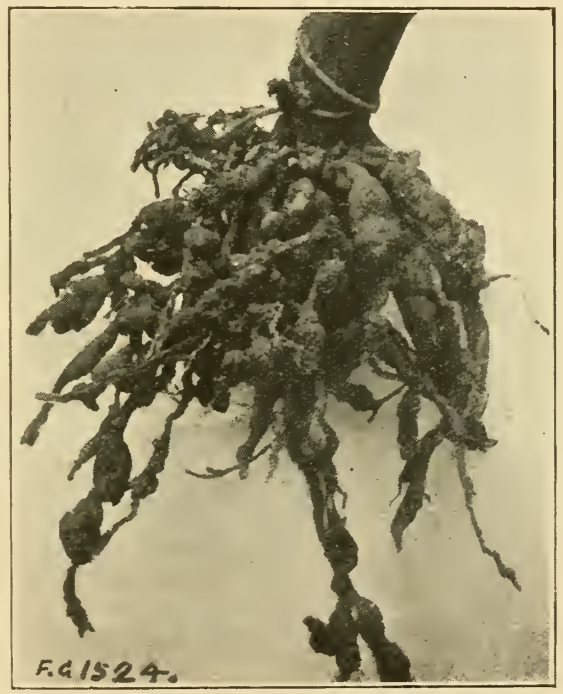

TOMATO ROOT EELITORM.

The roote are infested by microscopic worme, which produce galls or swellings on the roote.

Remedes - Maintain a moister atmosphere, and dust the leares freely with flowers of sulphur.

White or Snowy Fly (Aleyrodes vaporarianum). - A small white fly which infests the leaves and fruit of the tomato, sucking out the sap and crippling the foliage, as 
well as coating the surface with its excrement. The eggs are laid in large numbers on the under sides of the leaves, and the plants soon become swamned with active Hics, which dart away in cloud-like masses when disturbed.

Remeniss.-The best of all remedies is two or three repeated fumigations with nicotine. One fumigation is rarely successful.

Wireworms.--These are often introduced with the soil. If present, they eat their way into the stom of the plant and cause the latter to collapse.

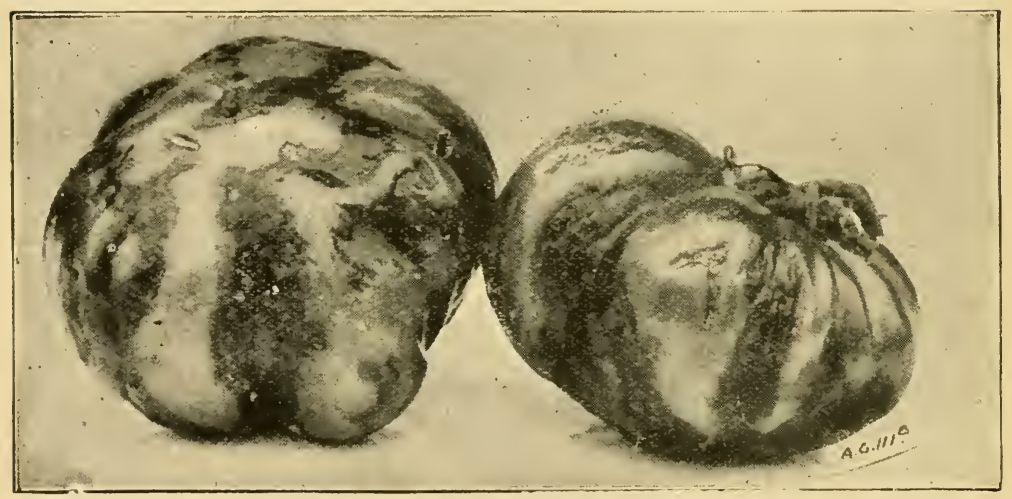

BROWX -TRIPE TOMATO DI-E.IEE.

Remeny. - Bury a piece of cut potato tuber in the soil at the base of the plant. Examine this daily, and if wire'worm be present the culprit will be found attached to the tuber.

\section{B. DISEASES.}

Black or Brown Stripe Disease (Macrosporium solani).--The stems and the fruits of tomatoes are sometimes marked with brown or black stripes, the result of a fungus working its way upwards from the roots. It appears that the fungus first attacks the roots, and then 
ascends the stems, abstracting the cell contents and disorganising the morement of the sap. In bad cases the fungus encircles the stern, cutting off the sap supply and causing the plant to wither and die. The stripes or blotches on the fruit are first of all brown, then black. Sometimes the leaflets turn inwards and upwards, become hrown, and discoloured streaks form on the fruit. IThen plants are grown in orer-rich soil brown spots appear on

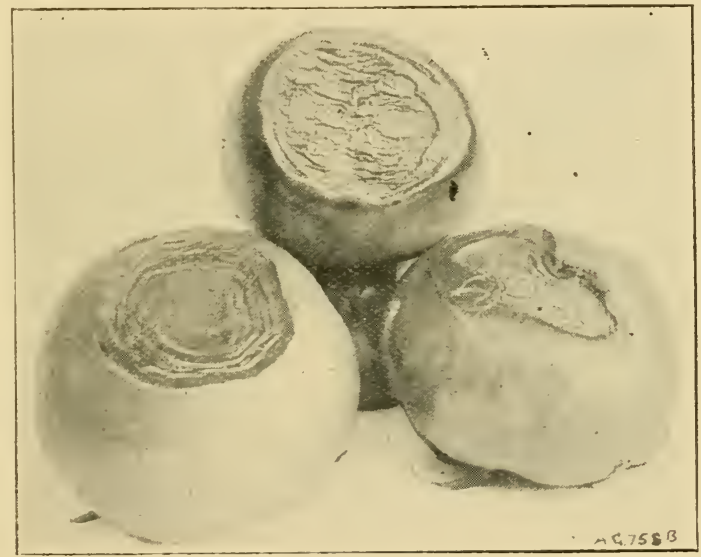

[Thoto: H. A. Emith.

TOWATOE; ATTACKED BI BLACK SPOT DISEASE.

The centres of the fruit have been turned black by the action of the fungus.

the leares, stems, and fruit, but these are thought to be due to the Potato fungus. This disease is also known as the Black Rot.

Reveses:- In the case of plants or fruit infected with the Stripe disease, the proper remedy is to at once burn the lot. Fungicides are useless in such a case. As a preventive it is adrisable to steep the seeds in a solution of Condr's fluid, or in a sulphate of copper solution (halfpound to a gallon of water). Should any of the spores of 
the fungus be present on the seeds this will destroy tilem. It is also a good plan to add a sprinkling of fresh lime to the soil in which the saeds are to be sown. The soil in which diseased plants have been grown should also be cleared out of the house, and be dressed with Formula No. 19. One grower recommends a pound of quicklime to every square yard, to be added to the soil before planting.

Black Spot, or Rot Disease.-Tomato fruits are frequently attacked by a fungus which causes the upper part to turn black and decay. This is known as the B3lick spot, or Rot Fungus (Macrosporium tomato). The fungus first appear's as a small black spot in the eye of the fruit, and gradually extends as the latter develops. It is possible that the spores are conveyed to the eye of the young fruits by insects. Anyway, the disease renders the fruit useless for consumption.

Remedes.-There is one satisfactory way of preventing the disease spreading, and that is by gathering and burning every infected fruit. It is quite useless applying fungicides. Nor should seeds be saved from infected fruits. Aphides and other insects should be destroyed by fumigation. Another disease of bacterial origin also causes the fruit to becone discoloured, black, and rotten. The remedy advised for Black spot should be arlopted in this calse.

Cracked Fruits.-Tomato fruits, when ripening, often crack their skins, and thus disfigure as well as in. duce them to decay. The cracking is due to extremes of dryness or moisture. Thus, if the soil be allowed to get overdry and then a copious watering be given, the hardening skin camnot withstand the pressure of the sudclen increase of moisture within, and the result is a fracture of the skin. Further, cracking may occur through absorption of moisture from the air; hence it is advisable to keep the atmosphere on the aly side when the fruit is ripening. 
sleeping Disease (Fusarium lycopersica). A fungoid disease which causes the leaves to assume a dull colour, then droop, and finally the plant to suddenly collapse. It appears that this fungus, as in the case of Black Stripe, which may or may not be due to the sime cause, first attacks the small roots, then the larger ones, and the base of the main stem. When it has taken possession entirely of the roots the drooping or sleeping of the leaves begins. I ater on a white mould appears on the

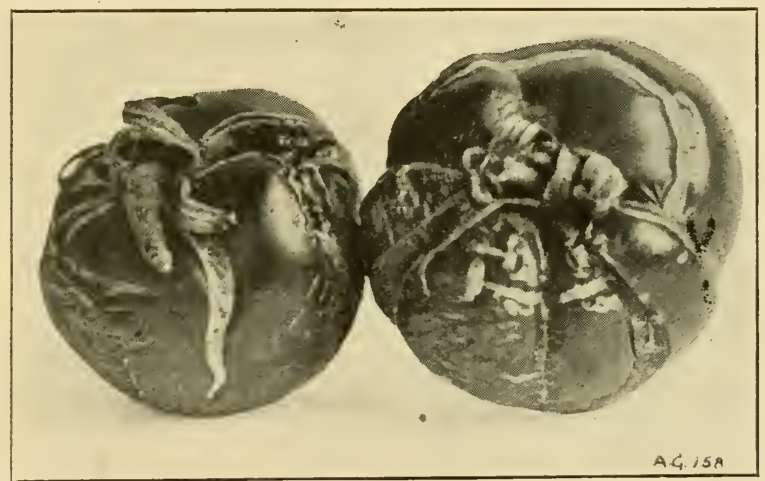

[Photo: H. A. Smith.

TOMATO FRUITS WITH CRACKED SKINS.

stem above the surface of the soil. When the leaves of a tomato gradually droop this may be regarded as evidence of the presence of the fungus.

Revemes. - Fungicides are useless in this case. All that can be done is to pull up and burn the plants, and the soil should be removed and dressed with quicklime. Such soil should not again be used for tomatoes if it can be dispensed with. The walls, paths, floor, and staging should be syringed with a solution of iron sulphate (Formula No. 29). Seeds, moreorer, should not be saved from fruits gathered from infected plants. 
Warty veins. The principal veins of the back of tomato leaves ale sometime's coruscatad, like the example firured. Such intumescences are, sars the late Profesisor Marshall Ward, "due to some disturbance of the balance of wrowth between transpiratory and assimilatory functions of their leaves," rather than disease or ins cotis. There is therefore no need to trouble about thom.

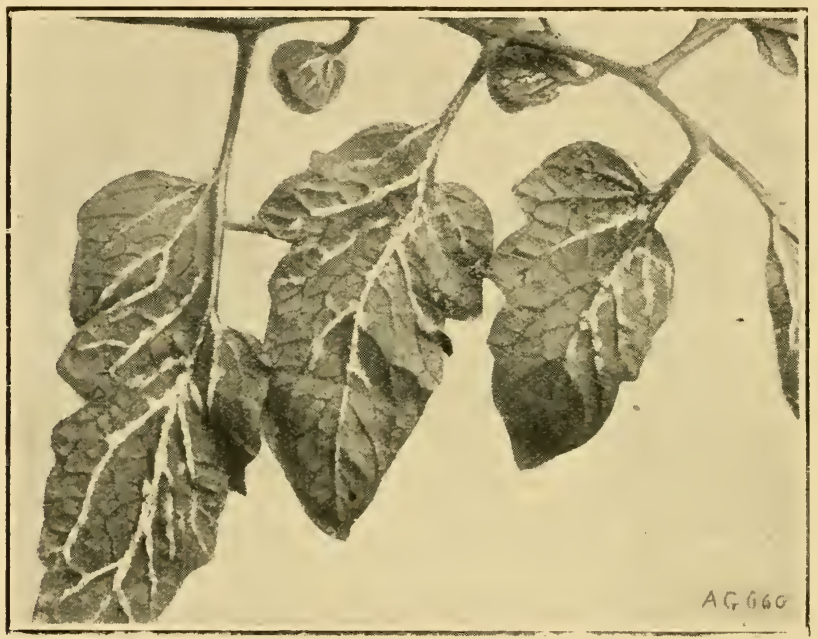

[Pho:o: H. A. Smith.

TOMATO LEAVES WITH WARTY VEINS

Yellow Spot Disease (Cladosporium fulvum).This fungoid disease is also known as the Torrato Teaf Rust. It first appears in the form of small brownish spots on the voung leaflets, the spots increasing in size until the whole or a part of the upper surface is covered. Later cut the spots change to a blackish-brown hue, and the leaves shrivel and die. On the mrder sides of the infected leaflets a thin growth of a rustr-brown tint forms. Then the stems of some of the infected plants often show stripes 
of a dark colour. In barl cases the fruit is also affected. This disease is of a virulent nature, and, once established cn a plant and not checked, will soon spread and ruin the crop. It has been found by experience that a moist atmosphere and insufficient ventilation, together with overcrording, encourage the development of the disease.

Remeries.-Once the disease has obtained a firm hold there is no cure. The best plan is to burn the infected plants. Preventive remedies are as follows: Maintain a dry atmosphere and ventilate the house early. Avoid late waterings. If only a solitary leaf is found infected gather and burn it. Spraying with Woburn Bordeaux Emulsion (Formula No. 21) is an excellent preventive. The fruit must be carefully wiped after spraying. One authority recommends wrapping the fruit in oilskin before spraying, but this is a terious business.

\section{CHAPLER XI. \\ VINE PESTS.}

\section{A. -INSECTS.}

Cushion Scale (Pulvinaria ritis). - Vines are wecasionally attacked with this scale, which gets on to the young shoots, and sometimes on the leaves and bunches, making them very dirty by their excrements. They are more easily seen by a white cottony substance which protrutes from under the scale in the summer time, and in which the young scales are enclosed.

Revedies.-Remove all loose bark from the vines, and then spray the rods thoroughly in winter with Formula No. 16, or well wash them with a solution of Gishurst Compound. 
Grape Moth (Batodes angustiorana). - A small moth of a yellowish and brownish colour, which lays its eggs on or near the berries of grapes grown under glass. From the eggs are hatched small active caterpillars of a greyish hue with buff hearls. These glue the berries together, pierce their slins, and feed on the flesh. In consequence the berries begin to decay, and the bunch is soon spoiled. When the bunch is touched the larva becomes quite active, and lets itself down to the floor by means of a silken thread.

Remenies. - Holk a tray smeared with treacle under the bunch, and give the latter a gentle shake, when the larvie will descend.

Mealy Bug (I)actylopius longispinus). - This is the most disagreeable pest of all when it gets among the bunches, which it is sure to do when there is a bad attack, and the grapes then are not fit to eat.

Remenies.--The grapes should be cut as soon as possible after they are ripe and put into bottles, and taken into a dark room. Then syringe the house with a paraffin emulsion, made as follows: Take two or three shovelfuls of fire from the vinery fire, and put outside surrounderl with bricks. Place a saucepan over the fire which will hold three or four gallons. Put into the saucepan two pounds of best soft soap and four ounces of washing soda, with half a pint of soft water. Stir the soap briskly while boiling with a good handful of twigs from a birch broom. When dissolved pour into it one gallon of good paraffin, and continue to stir briskly for fifteen minutes after it has boiled, taking care that it does not splash over into the fire. Take it off the fire and continue stirring until it comes into a stiff paste. Add to this 30 gallons of boiling water, and thoroughly syringe the vines, and everything in the house-even the rods right down into the ground. Do this again three or four days after, and, if properly made and used, no mealy bug or any other insect will be alive, and it will not injure the rimes. But it should be 
done before the leaves begin to decay. Dress the vine rods in the winter with eight ounces of Gishurst Compound to each gallon of water, working it into all the crevices with a half-worn-out paint brush. A careful watch should be kept the following summer, and if a mealy bug be seen just touch it with a small brush dipped in spirits of wine.

Red spider (Tetranychus telarius). - This is one of the worst pests to vines under glass. A bad attack will prevent the grapes ripening properly, and also injure the crop the following season. Its presence is first indicated by a few brown patches on the leaves. These patches may become as large again the following day, if it be a hot one, and the pest may spread through the whole house in a fortnight in hot weather.

Remedies.-Plenty of moisture is the best prevention, but it will not cure it. When the spots are first seen each affected leaf should be sponged, or brushed, with soft soap and sulphur. Mix four ounces of soft soap with one ounce of flowers of sulphur, and pour on to it one gallon of boiling water, and stir until all is dissolved. Lay the upper part of the leaf flat on to your hand, then put the mixture on the under side with a new paint brush or sponge, drawing the brush to and fro so as to work the mixture into the crevices and between the ribs. The brush is rather better than the sponge for the purpose. After every affected leaf has been brushed, syringe very forcibly with clear soft water. Red spider is nearly always on the under sides of the leaves, but they go to the upper sides when the sun is shining, in which case the brushing is best done when there is no sunshine. As soon as the grapes are cut syringe the whole house and vines with the same mixture at a temperature of $180 \mathrm{deg}$., or with five ounces of Gishurst Compound to each gallon of water. Thoroughly brush the rods over in the winter with eight ounces of Gishurst Compound to each gallon of water, working it into all the crevices and around the "eyes." 
Rust. - This is generally caused by some check to the berries when they are quite small and tender. Putting on a lot of ventilation when the house has become very hot will cause it. Syringing the pipes when they are very hot, and causing a large volume of hot steam, will also promote the development of rust. Putting sulphur on the pipes and making them hot when the berries are quite small will have the same effect.

Resedes.- There is no cure for rust, but it can be pre. vented by abstaining from doing such things as mentioned above.

Shanking.- Shanking is generally caused from the lack of sufficient food to supply the demand made upon the plant by the crop. This lack of food may be from cne of several causes. It is very often the result of orercropping of either the year in which it is seen or some previous year; a bad attack of either Red Spider or Mildew, which robs the leaves of nutriment, and prevents them carrying on their work; a wet, cold subsoil, or one that has too much animal manure in the borker, causing late autumn growth, the roots afterwards dying back during winter. If the borders are properly made and liept regularly mulched, so that the roots are near the surface, shanking will not take place from this cause.

Pexenes.-Lifting the roots and bringing them near the surface, as advised in renovating old vines, will remedy the evil if the roots are at fault. This disease causes the berries and stallis to shrivel instead of developing, and is easily recognised.

Thrips.-There are few insects more destructive than thrips. The one which attacks grape vines is Heliothrips hamorrhoidalis, a dark brown, four-winged insect, with a redrish-tipper bory, pale yellow eyes and limbs, and measuring 1-20in. in length. It is wonderfully agile in its habits, jumping away divectly the leaf it is on is touched. The larve- 
small whitish or yellowish maggots - are also fairly active, but they cammot jump. Both feed on the surfaces of the leaves and shoots, sucking out the juices, and causing them to assume a yellowish tinge and die. Not only do they injure the leaves, but also the young shoots and flowers. They are especially destructive to the young and tender foliage of vines. Is a rule, they never get very numerous in vineries that have a fairly moist atmosphere.

Rexenies.-Sponging or spraying the foliage with an insecticide, or fumigation with a nicotine preparation on three successive evenings generally proves successful.

Vine Louse (Phylloxera vastatrix). - This is very injurious to the vineyards on the Continent, and has aliso done a great deal of damage in some places in England, attacking both leaves and roots. When the leaves are attacked they have a warty appearance, and the roots become covered with knots.

Remedies.-The only sure remedy is to burn the vines and roots, thoroughly clean the house with paraffin emulsion, and paint all the woodwork; then take all the soil out of the border and malie a new one. This disease must be notified to the Board of Agriculture. See Chapter V., Part VII.

warts on the Leaves. - Warts, when they are extensive, interfere with the functions of the leaves, but slight cases of wartiness are not very harmful. It is frequently caused by a check, such as ventilating too freely when the house is very hot, improper removal of foliage, etc.

\section{B.-DISEASES.}

Black Rot of Grape Vine (Guignardia Bidwellii).This disease is not very common in Britain, but still it is just as well that readers should be acquainter with its life history, and the best way of coping with it. The general appearance produced by the disease is well 
marked, and when once seen is not likely to be confomaled with any other form of fungous attack. The young leaves, and especially those low down on the vine, are usually the first to show the symptoms, which appear under the form of irregularly-shaped brown blotches, half to one inch across, looking like the effects of sun scald, for which they might easily be mistaken but for the presence of numerous minute black points scattered over the surface of the diseased patches, which correspond to the fruiting

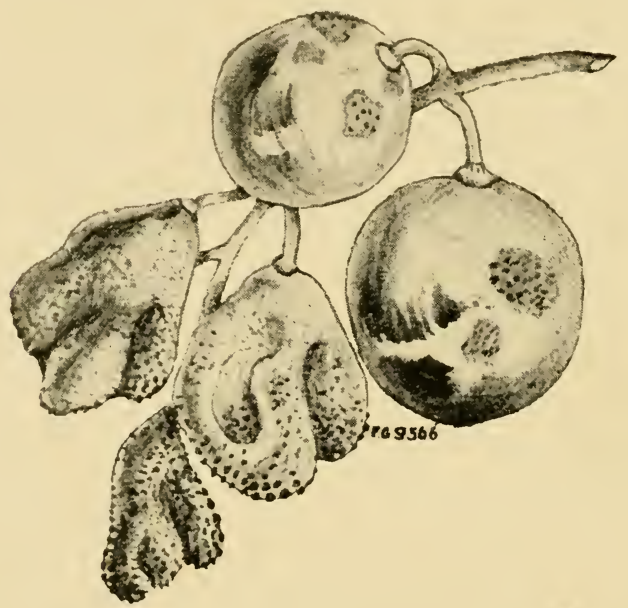

GRAPES INFECTED WITH "BIACK ROT" FUNGUS.

organs of the fungus, which can be clearly seen under a magnifying glass. Three or four different kinds of spores, or reproductive bodies, are produced by the fungus, each of which is capable of infecting and causing the disease on any leaf or fruit on which it may happen to be deposited, providing the surface be damp; the spores camnot germinate on a dry surface.

As a rule, about a month after the disease has appeared on the foliage the fruit is attacked. Blotches of variable 
size appear on the grapes, and after a few days these blotches are studded with minute blackish warts-the fruit of the fungus. Within a short period of time the diseased grapes become dry and much shrivelled, but remain hanging for a considerable time. During the

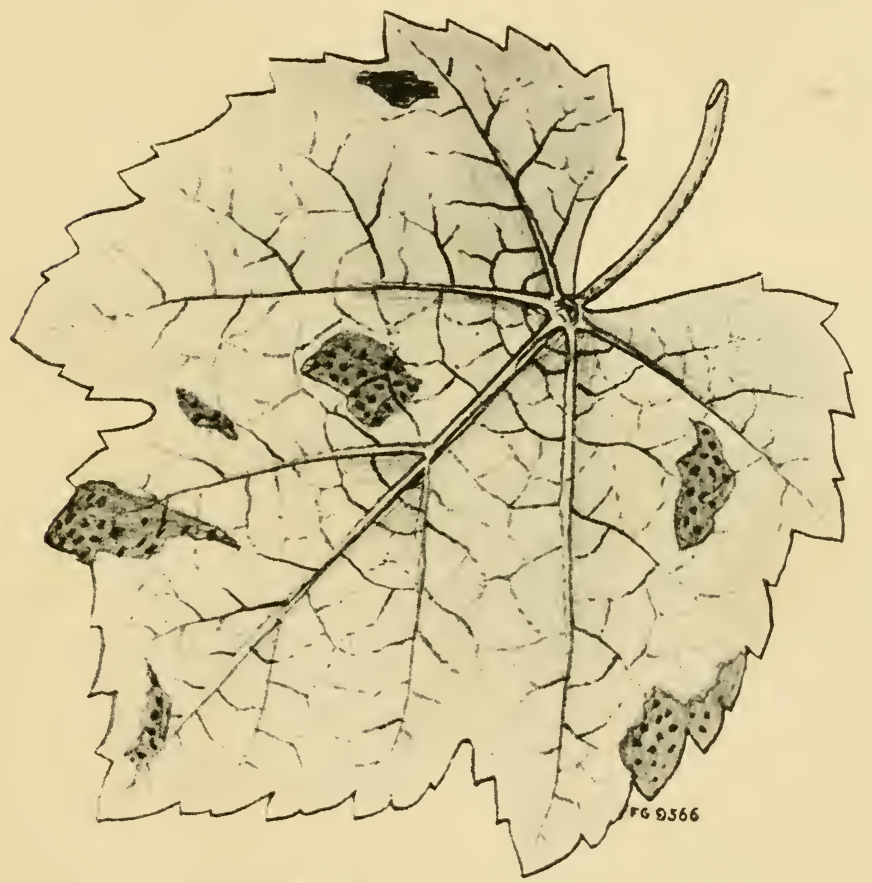

TINE LEAF SHOWING "BLACK ROT" FUNGUS.

winter numerous minute black sclerotia, or hardened masses of fungus mycelium, form in the skin of the fruit, and in the following spring, about the time when the leaves are unfolding, these sclerotia produce two distinct kinds of fruit, either of which is capable of infecting the roung leaves, thu producing a repetition of the disease. 
The fungus cin only sprearl to any extent when the temperature is fairly high, and the air contains a considerable quantity of moisture. In this country, where vines are grown under glass, those conditions most farourable for the development and rapid diffusion of the fungus are constantly present, and great care must be exercised in the matrer of ventilation, so as to avoid an undue deposi-

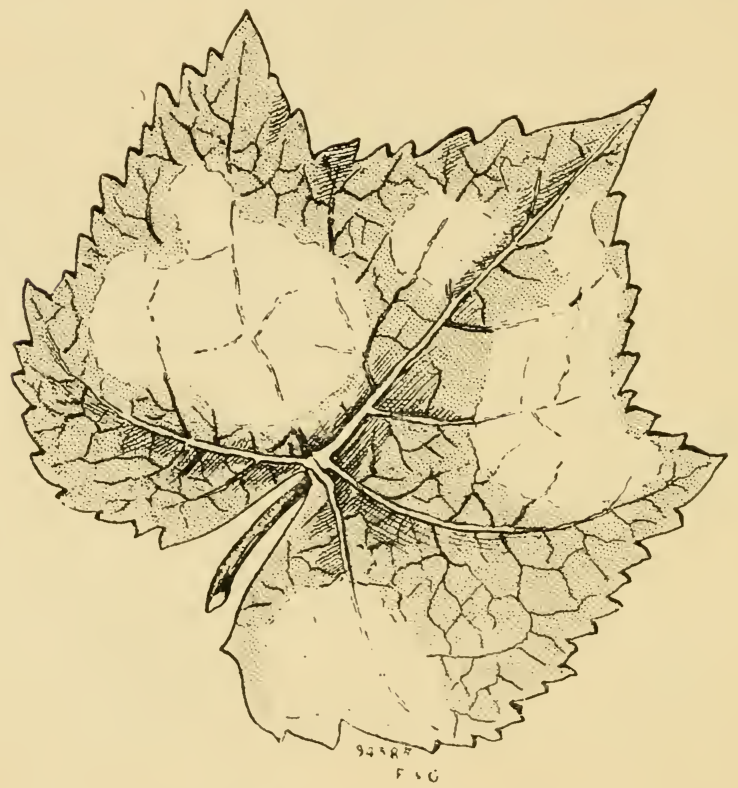

POWDERY MLDEW OF THE TINE.

tion of moisture on the surface of leares or fruit; and, furthermore, ventilation must be so effected that the fruit is quite dry before being exposed to sunlight, otherwise rusting of the grapes is apt to occur, a feature bat enough in itself, and in addition greatly favouring the spread of the disease. 
Remedies.-If the disease be present, spraying with vilute Bordeaux Mixture (Formula No. 21) is the best that can be rlone; application should be made at intervals of ten days until the grapes are the size of peas, when Bordeaux Mixture should be replaced by an ammoniacal solution of carbonate of copper (Formula No. 22), which will not spot and disfigure the fruit.

Diseased leaves and fruit should be collected and burned, and it is very important that such diseased portions should not be allowed to fall and remain through the winter on the ground or in neglected cornens, otherwise the sclerotia present in the tissues will produce spores the following spring and infect the young growth.

Downy or False Mildew (Plasmopara viticola).This fungoid disease is of American origin, and "makes its appearance," says Dr. W. G. Smith in his "Diseases of Plants" (Longmans and Co.), "in early summer as white patehes on the under surfaces of the leaves, sometimes also on the stalks and fruit. In the course of the summer the leaves show brown spots, and dry up." It seems that the disease is most prevalent in moist weather, and hence it naturally follows that rineries which are not properly ventilated will provide suitable conditions for the development of the fungus.

Remenes. - Spray the foliage, as soon as the berries have formed, every ten days with the Ammoniacal Solution of Carbonate of Copper (Formula No. 22), or with the Woburn Bordeaux Emulsion (Formula No. 21). These remedies must not be applied after the berries begin to colour.

Mildew (Uncinula spiralis). - Vines grown under glass and in the open air are often attacked by a form of mildew peculiar to the vine, and as grape growers ought to be able to recognise the fungus in order to deal promptly with it, we give full details of its life history, with the best remedies for its eradication. If allowed to 
develop on the shoots, leaves, and herries it is liable to do serious injury to them.

The mildew appears on the surface of the leaves, ete., in the form of a greyish-white powder. The powdery ippearance is due to the presence of myriads of minute slmmmer spores, which are produced in enormous quantities, and in quick succession throughout the summer

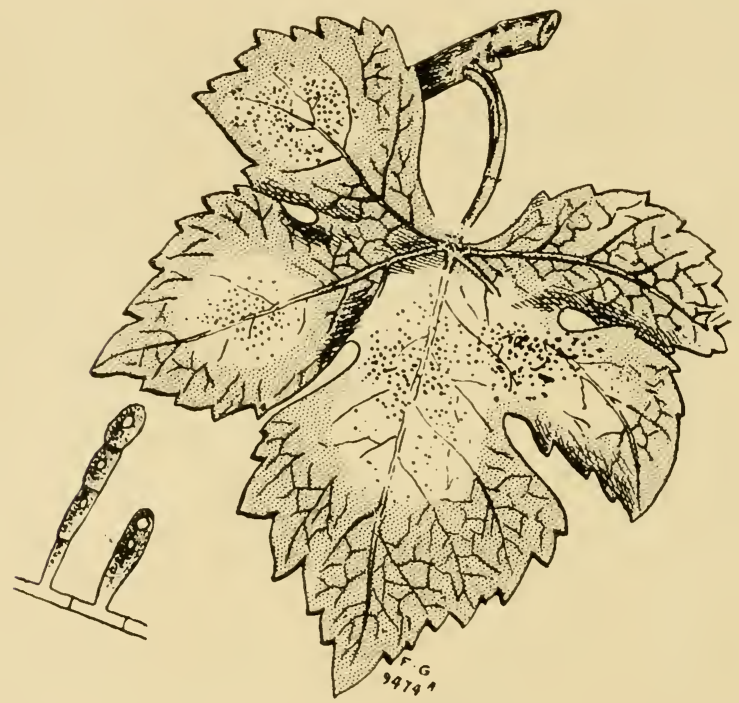

VINE LEIF MLDEW.

Showing patches of mildew, or summer fruit of Plaemopara viticola, on its under surface; natural size

months, and accumulate on the mildewed patches until removed by wind or rain, and such of those as happen to alight on the damp surface of a vine leaf germinate quickly, and soon produce a patch of mildew. The spores are oval, and are formed in chains, the uppermost spores of the chain becoming free and falling away as soon as they are ripe, young spores being at the same time 
developed at the bottom of the row or chain. The mildew develops on the upper surface of the leaves, young shoots, and fruit.

During the autumn thesummər form of fruit ceases to be produced, and in its place minute balls, at first yellowish, and afterwards blackish brown, appear in considerable numbers on the mycelium still present on the

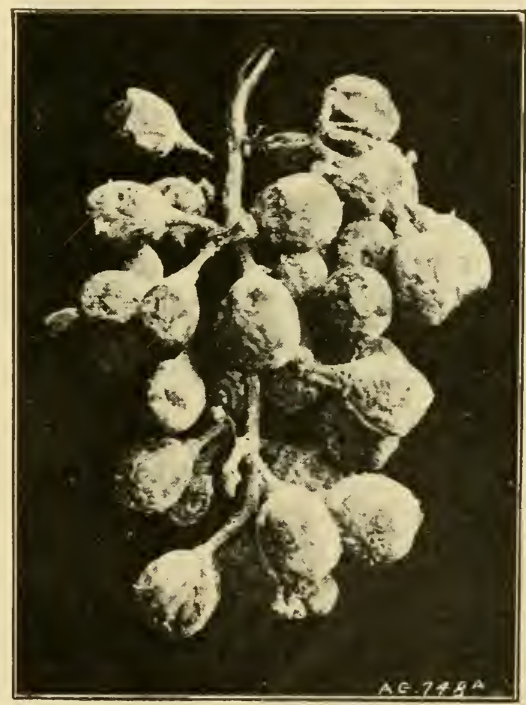

[Photo: H. A. Smith.

BLNCH OF GRAPES INFECTED WITH MILDEW.

leaves, shoots, and fruit. These minute balls, smaller than the heard of a small pin, represent the winter form of fruit, containing spores in their interior. Examined under a microscope, these winter fruits are very beautiful, being provided with a circle of delicate spreading spines, each of which is more or less curled at the tip. These winter fruits remain unchanged until the following spring, 
when the spores escape and inoeulate the young leaves and shoots, giving origin to the summer form of fruit.

liemedies.- In the matter of applying fungicides it is all-important to remember that no one mixture, however valuable, can be looked upon as a preventive or cure for all known fungoid diseases. Flowers of sulphur is very effective against vine mildew. Special bellows should be used to secure a thin and even dusting of the substance on the leaves, shoots, and flowers. The first application should be made when the leaves are just full grown, and a second when in full bloom. A third application should be made about a month later if the disease is not stamped out. The most certain result is obtained with the teniperature ranging from 80 deg. to 100 deg. Fahr.

Excellent results also follow spraying with a solution of potassium sulphide (Formula No. 23). This preparation is cheap, and can be effectively applied with any form of sprayer, and, being perfectly colourless, leares no mark on the plant. The times for application are the same as for Howers of sulphur.

Shoots that are attacked should be removed and burned, as the winter fruit is not destroyed by the fungicides mentioned. Fruit should also be promptly removed when it shows indications of the disease, as it camnot possibly be of any value, and may serve to spread the disease if allowed to remain on the vine.

Finally, scrupulous care in collecting and burning fallen leaves and fruit that are diseased must be attended to, otherwise a single slrivelled berry or fragment of a leaf hiding in some crevice may be the means of introducing the pest the following season. 


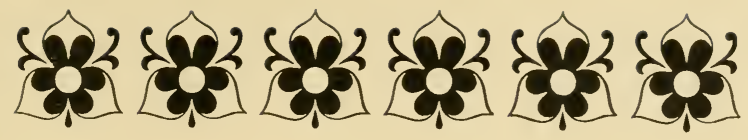

\section{Part III.-VEGETABLE FOES.}

\author{
('HAPTER I
}

\section{INSECTS, ETC,}

Asparagus Beetle (Crioceris asparagi). - This is a most destructive insect pest. The beetle is about the :ize of a rather small house fly; it is red and yellow, with black spots and black legs. The beetles may often be seen about the beds while the asparagus is being cut, and every one should be killed. They somewhat resemble the ladybird in colour, but are longer and not so wide. One heetle will lay hundreds of eggrs on the stems and leaves in late spring; the eggs hatch out in a few days, and the larve conmence eating the leaves, learing nothing but bare stems. When plants are badly infested no good asparagus will be produced from the erowns the following year.

Reuedies. - The best way of destroring the larve is to poison the leaves they are eating. This may be accomplished by spraying the foliage with Formula 10. In autumn lightly fork into the bed one of the soil fumigants, as Apterite, Clift's Powder Insecticide, Kilogrub, or Vaporite, to asphyxiate the pupa.

Bean Aphis, or Dolphin Fly (Aphis fabie).Besiden the names given above, this pest is also known 
as the "Collier," " Black Fly," and "Black Dolphin." It belongs to the Greenfly family, but we deal with it separately because of its great importance. The young Aphides

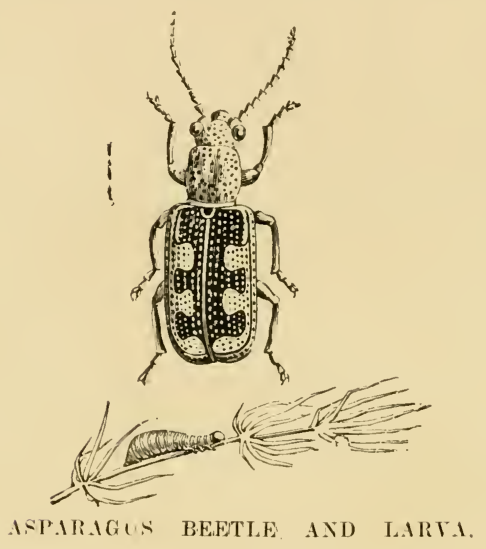

are slatey-grey in colour, and the female and male of a blackish hue. The Aphides will be fouml swarming in clusters on the points of the shoots, and, if mmolested,

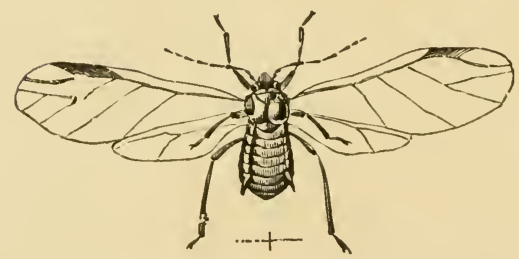

A.

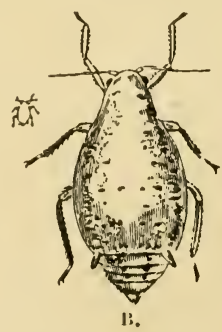

BE.IN APIIS (IPHIS F.IB.E).

$\Lambda$, male, and $B$ female aphis; ratural sime and magnified.

will speedily cover them with a sticky juice, filthy to handle, and decidedly detrimental to the plant. The Aphiles increase very rapidly, and will soon diestroy the plants and the prosperets of a crop. 
Pemedies.-.. If plants are badly infested there is no remedy, as the insects will have sucked all the nutriment out of the shoots and completely paralysed the growth. In the latter case the plants should be promptly burnt. Where only a few aphides are seen, nip off the tops into a pail and burn them, or trample them well underfoot, or syringe with Formula 14. J)usting with lime and soot is also a good remedy.

Beet Carrion Beetle (Silpha opaca).-This is a small black beetle barely half an inch long, and covered with yellow hairs. It is a common pest, frequently met

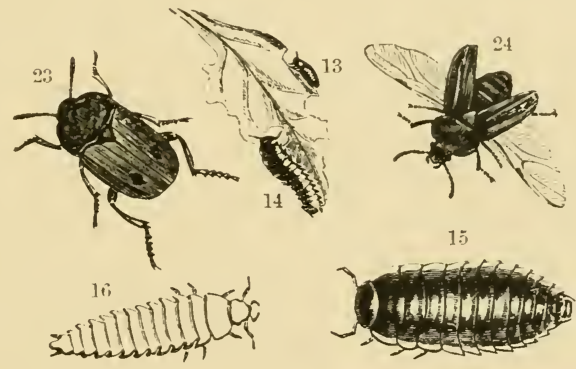

BEET CARRION BEETLE.

References : 13 and 14, Larva feeding on leaf; 15, Typicul larva ; 16, Anothed view of larva; 23 , Beetle; 24 , Beetle with wings expondert.

"ith feeding on dead animals, but is also very partial to the leares of the beet and the mangold. The grubs or larve are, however, the most mischievous. They are black and shiny, like a woodlouse in shape, and a third to half an inch in length. They feed chiefly at night, and do the greatest damage in spring.

Remedies. - Where very troublesome spray the foliage at night with Formula 16. Dressings of soil fumigants, as Apterite, Clift's Powder Insecticide, Kilogrub, and Vaporite, dug into the soil before sowing, will kill these and all other earth grubs. 
Beet or Mangold Fly (Anthomyia beta).-This is the parent of small yellowish-white or greenish maggots which feed on the pulp or inner tissues of the leaves of beet and mangold. The leaves, in consequence, shrivel, and the growth of the plant becomes severely checked. The fly lays its white eggs on the moler sides of the leaves. In due course maggots are hatched, which pour through the outer skin, and devour the pulp. When fully grown the maggots escape, bury themselves in the soil, and eventually derelop into flies.

Remeums. - The best remedy is a preventive one, namely, to encourage the plants to grow sufficiently vigorous to resist the attack of the maggots. Keeping the soil well stirred disturbs the flies, and prevents them laying their eggs. A dressing of one of the above soil fumigants before sowing will prevent a future attack of this pest.

Blue Cabbage Flea (Haltica consobrina). - This is a tiny violet-coloured beetle, the parent of a small sixlegged maggot which forms tumnels in the tissues of cabbage and turnip leaves. The maggots feed on the soft tissues, and do much injury to the leaves when yomg.

Remedes. - The main point to observe is to encourage the erops to grow freely in their earlier stages, by using artificial or liquid manures. Liberal liming in February and using the hoe freely in summer will help to reduce these pests. Pick off the worst infested leaves and burn them.

Cabbage Aphis (Aphis brassica). - This pest is a relative of the Common Greenfly, and attacks the mder sirles and folds of the leares of cabbage, kale, Brussels sprouts-in fact, all members of the cabbage tribe. It injures the foliage by sucking the sap, and in due course causing it to become reformed and sickly. The aphides are the most prevalent in summer, and particularly so in dry seasons. The insects are of a vellowish colom when young. Tater the fernales assume a greenish tint, and are covered with meal. 
Rexenies.--Prompt measures shoukl be taken to get rid of the aphides when first discovered. The best remedy is to spray the foliage with "Abol" Wash or Formula 16.

Cabbage Fly (Anthomyia brassicie). - The larve of this fly and of an allied species, $\Lambda$. rarlicum, attack the

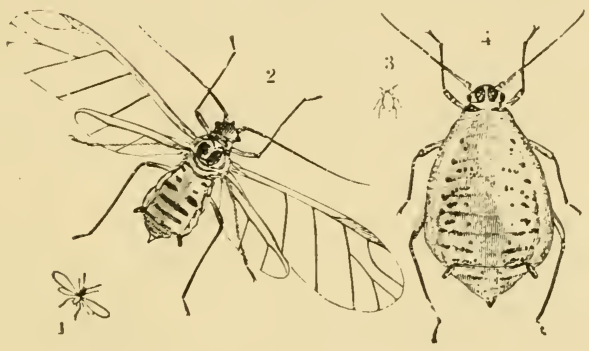

CABBIGE APHIS (APHIS BRASSICE).

Fig. I, M 1 o aplis, nat. size; 2 Ditto, mannified; 3 Female aphis, nat. size; 4 Ditto $n$ ag.ified.

lower part of the stems of cabbages and allied crops, eating their way into the tissues, causing the stem to decay and the plant to die. Plants infested with the larve have leaves of a learlen hue that readily droop when the sun

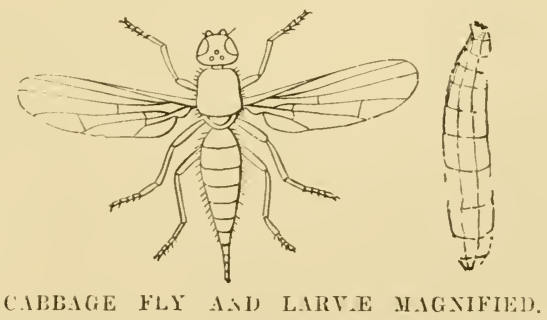

shines on them; also the base of the stem and the roots are furnished with swollen lumps, within which are tze maggots. The latter are about one-third of an inch in length, white, and leglesis. The fly lays its eggis low down 
on the stems of the plant, and the maggots appear a fortnight afterwards.

Remenies. - Pull up and burn all plants that show signs of attack by drooping. As a preventive, apply a dressing of Apterite, Clift's Powder Insecticide, Kilogrub, or Vaporite, ligging this well into the soil before planting. The gas cmitted will asphyxiate the pupae, and prevent them developing into flies later on.

Cabbage Powdered-wing Fly (Aleyrodes proletella).-This fly attacks all the members of the cabbage
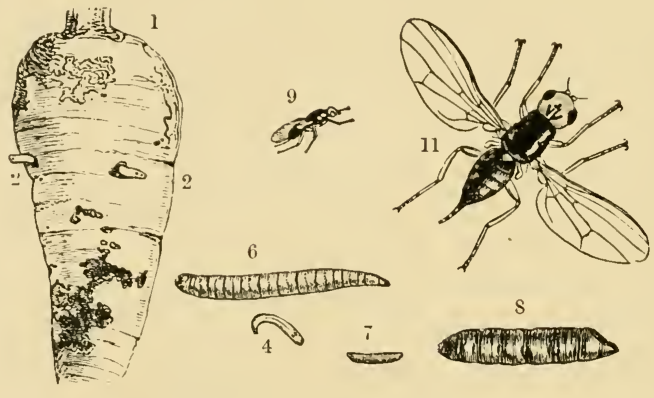

\section{CARROI FLY AND LARVA.}

References: 1, Root infes 3 with maggots; 2 , Maggots in root; 4 and 6 , Larve; 7 and 8 , Pupre; 9 and 11, Fly.

family by congregating on the under sides of the leaves and sucking out the sap from the cells. Plants attacked turn yellow or brown in their foliage. The young insects are covered with small scales, and adhere firmly to the leaf. When they reach maturity they have white wings, and float in the air like tiny snowflakes.

Rements. - The best remedy is to remove the leaves containing the young insects and burn them. Where the insects can be readily reached spray with the solution advised for Cabbage Aphis.

Carrot FIy (Psila rosie). - The maggot or grub of this fly is responsible for the formation of the rusty patehes on 
the roots of carrots. The flies, which are small, lay their eggs on the roots of the carrots in early summer. When hatcher the maggots at once bore into the soft parts of the roots, form carities, and generally disfigure the roots. The maggots are yellowish-white, shiny, and a quarter of an inch long. Carrots attacked by this pest have pale foliage and a stunted growth.

Remedies.-To guard against a possible attack give the soil a dressing of Apterite, Clift's Powder Insecticide, Kilogrub, or Vaporite before sowing the seed, in order to destroy the pupie, and prevent them dereloping into flies.
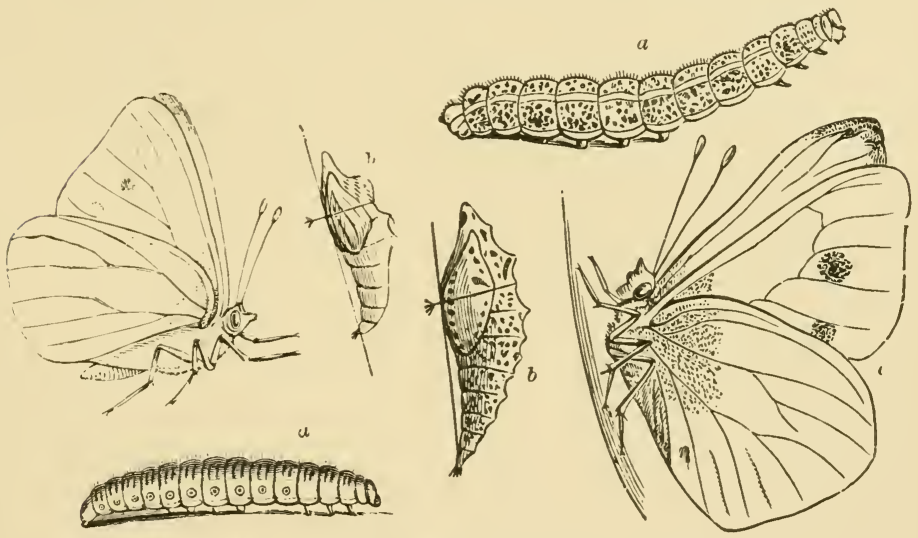

SALL AND LARGE WHITE AABBAGE BUTTERFLY. $a$, Caterpillar; $b$, Chrysalio; $c$, Butterfly.

If one of the above be used there will be no trouble with the Carrot Fly grub.

Caterpillars.-Quite a number of larve of moths and butterflies infest vegetable crops, many of them doing serious injury if not promptly dealt with. Thus the larvae of three kinds of butterflies-the Large White (Pieris brassica), Small White (Pieris rapæe), and the Greenveined (Pieris napi) feed on vegetables of the cabbage 
family. The larve are yellowish, marlied with yellow stripes and dark dots, and appear in summer. Then there are the larvar of the Cabbage Moth (Mamestra brassica), which attack similar crops. These are first of a greenish tint, changing later to a darker one, and appearing largely in late summer and autumn. The flowers and seerls of

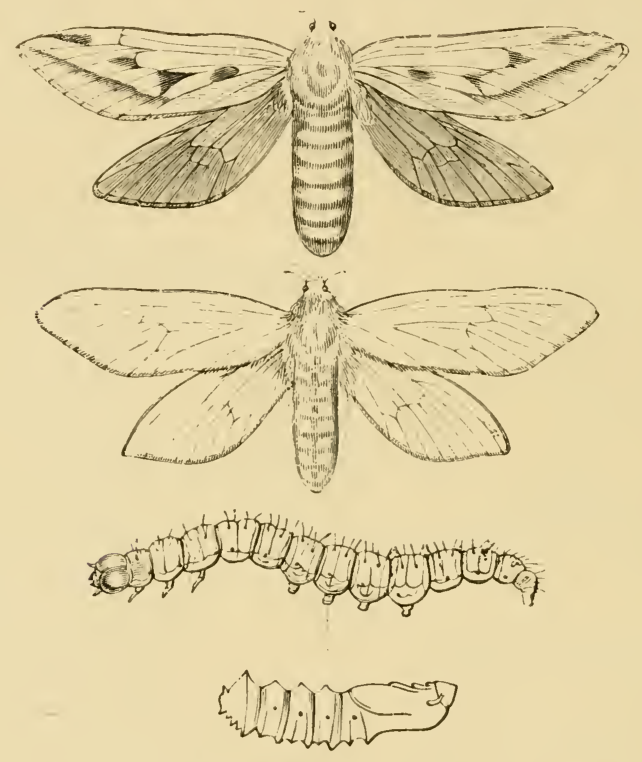

GHOST OR OTTER. MOTH (HEPIALES HUMULI).

The upper figure is the female and the lower, the male moths. Next is the larva and then the pupa.

the carrot are also attacked by the small brownish-grey, dark-spined, hairy larve of the Carrot-Seed Moth (Depressaria depressella). The green larvie of the Common Flat-Body Moth (Depressaria applana) feed upon the leaflets of the carrot and parinip. The Dart Moth (Agrotis segetum) caterpillar's feed on the roots and leaves of the 
turnip by night, and hirle in the soil by day. They are active in autumn and winter. The Diamond Black Moth (Plutella cruciferarum) larve, with greenish bodies and yellow heads, do immense injury in some seasons to the foliage of turnips. The larve of the Garden Pebble Moth (Pione forficalis), yellowish-green, devour the leaves of cabbages and turnips in summer and autumn; the creamywhite and spiny larve of the Gho:t Moth (Hepialus humu i) feed on the roots of lettnce in autumn and winter; and

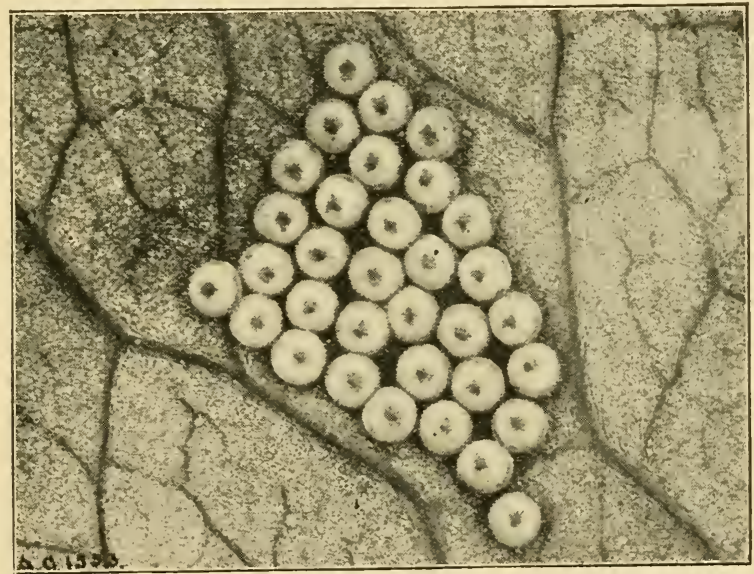

[Photo: J. G. Blakey.

EGG; OF THE CABB.GE MOTH (M.ME-TRA BRASSIC.E).

The eggs, which are largely magnified, are laid on the under side of the leaf.

the reddish-brown tuberculed Caterpillars feed on the leaves of regetables by night and hide in the soil by day. Then there are the larve of the Yellow Underwing Moth (Triphena pronuba), a greenish-brown Caterpillar striped with rose, brown, and black, which feeds by night and hides in the soil by day. This pest attacks the stems of young cabbages, lettuces, etc., causing the plants to wither and die. 
Remenes.- Hathl-picking in the case of those larve that feed on the foliage by day is the most effectual remedy. Syringing with quassia and soft soap (Formula 1.1) would also be efficacious if applied before the larve have advanced far in size. In the case of those larve that inhabit the soil, dressings of Apterite, Kilogrub, or Vaporite dug well in would suffocate most of them. In any case, apply a soil fumigant in autumm to destroy any pupe present.
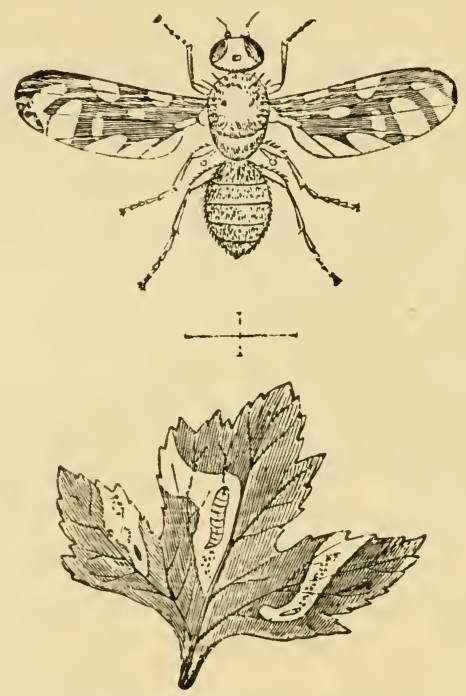

CELERT FLT AND MAGGOT.

The maggot can be seen in the leaf.

Frequent hoeing of the soil to harass and worry the pests would be advisable also.

Celery Fly (Tephritis onopordinus). - This insect attacks the leaves of parsnips, celery, and parsley. The fly is about one-sixth of an inch long, of a brown colour, with two transparent wings and green eyes. The female deposits her eggs within the skin of the celery leaves, where they 
are hatched, producing small green larve, which cause large blisters upon the leares. These larve, or maggots, cause complete or rapid decay of the foliage. The brown pupe of this fly are found on the leaves of the host plant and in the earth; as a rule, the maggots leave the host plant and turn to pupe in the earth. There are several broods during the year, but the pupe last produced hibernate in the soil until the following spring, when they appear as perfect insects and renew the attack.

Remellas.-Owing to the maggots feeding within the leaves, it is difficult to apply any insecticide that will reach them without at the same time destroying the foliage. Picking off the portion of leaf infested, and burning the collected portions, is the only remedy once the maggots are in the leaves. The flies may, however, be prevented depositing their eggs by spraving the foliage occasionally with the following preparation: Mix half a gallon of tar with a gallon of water, and place this on a fire till it boils. When cool add fiftr gallons of water, and then spray the foliage thoroughly with it. Another good plan is to pour as much paraffin oil on a piece of brick as it will absorb, then steep this for a day or two in three gallons of water. Remove any scum that forms, then spray the foliage. Spraying should be done during May, June, and July. Before preparing the trenches dress the ground with one of the soil fumigants previously describerl, to destroy the pupe and prevent them developing into flies.

Celery-Stem Fly (Piophila apii). - The fly is somewhat similar in size and form to the Celery Fly, which see. It has a black, shiny body, clothed with golden hairs. The maggot is yellowish-white. The latter borcs into the root stock of the celery, and thence upwards in the leaf-stallss, causing rusty-brown patches to form.

Remedy.-There is only one, and that is to burn all infested plants, and dress the soil with one of the soil fumigants to kill the pupa. 
Cockchafer Beetle (Mclolontha vulyaris).-The Cockchafer Beetle measures about an inch in length, has a black body covered with grey down, and rexldish-brown wing-cases. The female lays her eggs beneath the surface of the soil, and from these are hatched flesh-white grubs with curved bodies. The grubs remain three years in the larval stage, and appear as beetles in May or June. They feed on the roots of plants.

liemeny. - The only satisfactory remedy is to pick out and destroy the grubs when digging, and to use one of the soil fumigants previously described.

Crickets (Gryllus domesticus). - The House Cricket is partial to the fruit of cucumbers, disfiguring them by gnawing the rind.
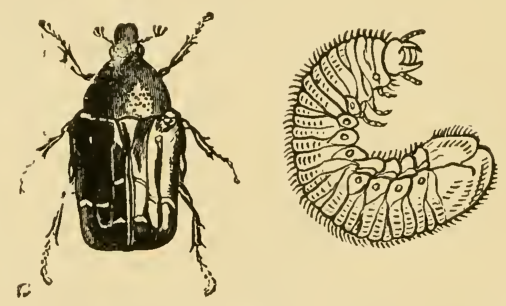

COCKCHAFER BEETLE (MEIOLANTHA VULGARIS).

Remeny.--Use one of the beetle poisons sold by chemists.

Cucumber Eelworm. - See Tomato Root Eelworm in Chapter X., Part II.

Leather-Jacket Grub (Tipula oleracea).-This is one of the most insirlious of garden pests. Unfortunately it carries on its nefarious work by night, and consequently is rarely caught in the act of gnawing the stems of lettuce, cabbage, carnations, and pansies. The Leather-Jacket, so called because of its tough, leathery skin, is the larva of the Dadkly Long-Legs, or Crane Fly (Tipula oleracea). The latter fly deposits its eggrs at the base of the stems of grasses in pastures or lawns, and from these are hatched 
tawny, legless grubs, with an abrupt or truncated tail. The grubs work their way through the soil, or come to the surface at night, and feed on the stems of plants and grasses.

Remedy.--There is only one way of dealing with this pernicious pest, and that is digging in, in autumn or prior to planting, one of the soil fumigants described elsewhere.

Lettuce Fiy (Anthomyia lactuce). - The larve of this fly feed on the seed of lettuce, and occasionally ruin the crop. The larve are yellowish-white in colour, a quarterinch long, and footless. The fly is about the same size as the housefly, brownish-black, with brown wings, and lays its eggs in the blossoms in early summer. Those, therefore, who grow lettuce for seed should take special care not to allow the maggots to exist in large numbers.

Revedy.--See that the seed before sowing is free from the pupe of this insect. Plants infested with the maggots should be burnt at once.

Lettuce Root Aphis (Pemphigus lactucarius).Large lettuce plants sometimes droop and look sickly. On pulling up the plant the roots will be found infested with insects, having their bodies clothed with fine cottony down. These are the Lettuce Root Aphides. They cluster round the base of the stem and on the roots, and suck cut the sap from the cells.

Remedis.-Burn every infested plant, and dress the land afterwards with Apterite, Clift's Powder Insecticide, Kilogrub, or Vaporite.

Millepedes (Juluis).-These small, active little animals, commonly known as Thousand Feet, are sometimes a source of trouble to the gardener. Although their natural food is supposed to be decaying matter, they are known to attack the seeds of runner and kidney beans and peas soon after sowing, and either destroy the germinating power of the latter or weaken the embryo plant. There are at least three kinds that are hurtful to seeds-namely, 
Julus guttatus, an inch long, very slender, with an ochreous-coloured body, spotted with crimson; Julus terrestris, which is about an inch long, leaden or pitchy in

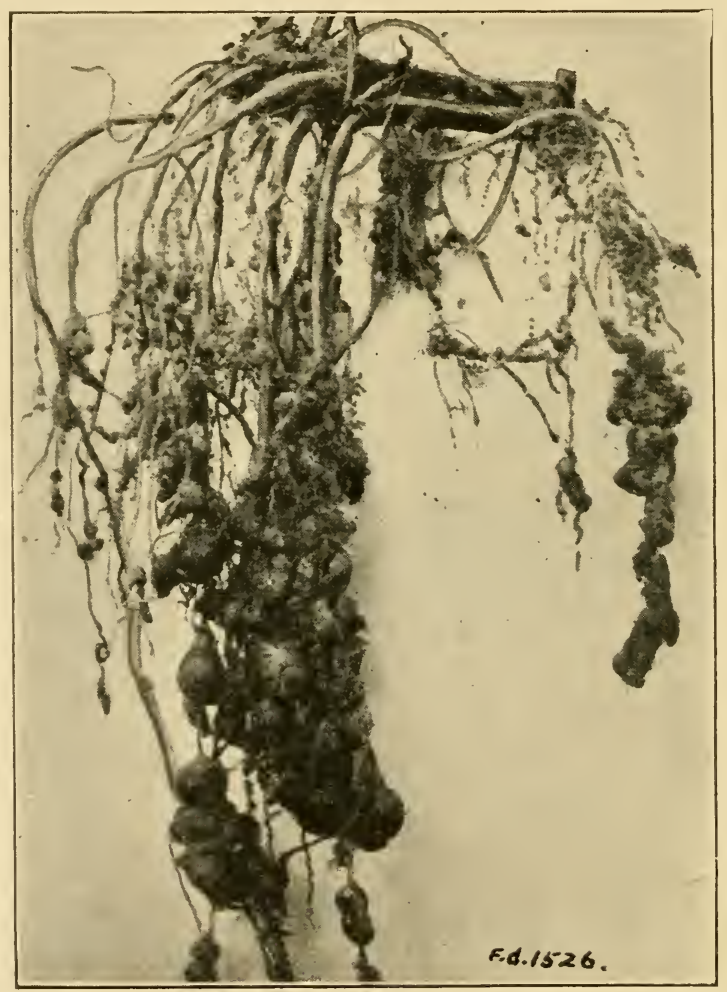

CTCLUBER ROOT EELWORM.

This pest attacke the roots of the cucumber, and often ruins a whole crop of plants.

colour, and more or less cylindrical in shape; and Polydesmus complanatus, a flat kind with a lilac-tinted body. 
All are furnished with a large number of legs. The Spotted Millepede (J. guttatus) may be found in clusters, devouring the seeds, especially in cold, backward seasons, when germination is retarded. The Millepedes are often mistaken for wireworms, but a reference to the illustrations of each will show that they are quite distinct.

Resenies. - If the soil be dressed in autumn or before sowing or planting with Clift's Powder Insecticide, Kilogrub, or Vaporite, the Millepedes will speedily disappear and cause no further trouble.

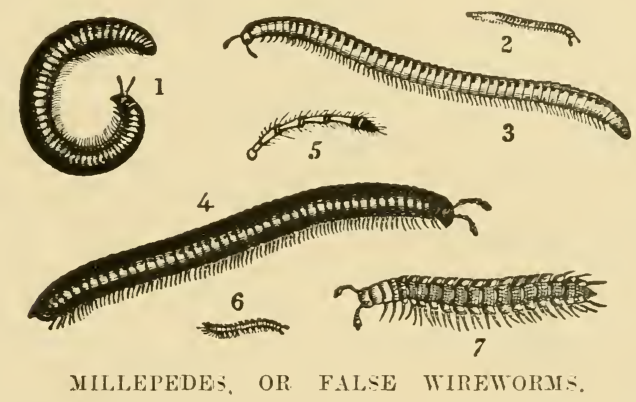

Fig. 1, Julus terrestrus curled up; Fig. 2, Julus guttatus, natural size; Fig. 3, Ditะo, largéiy magnified; Fig. 4 Julue terrestris, natural size; Fig. 5. Horn or antenna of Fig. 4 ; Figs. 6 and 7 , Polydesmus camplanatus in a young and natural state. These creatures are furnished with numerous lege. and therefore easily distinguiehed from the True Wireworms. They feed on decaying c.ede and roots of plants.

Mushroom Beetles. - A species of liove Beetle (Quedius) and of Dung Beetle (Aphodius) occasionally do injury to mushroom crops, eating the young and mature mushrooms, and disfiguring them for use or sale.

Remedies.-In case of crops being injured thus, trap the beetles by placing pieces of liver here and there on the beds. As these beetles are carnivorous as well as regetable feeders, they will greedily feed on the liver, and be thus easily caught. Slates smeared with tar and placerl on the berls will also catch the beetles. 
Mushrocm Pest (Scialla ingenua).-These active little insects often infest mushroom beds, and do considerable injury to the crop.

Remenies.--Spray the walls, soil, and floor before spawning with 2! per cent. of lysol; or dissolve two ounces of salt in a gallon of tepid water, and sprinkle the beds after soiling with this.
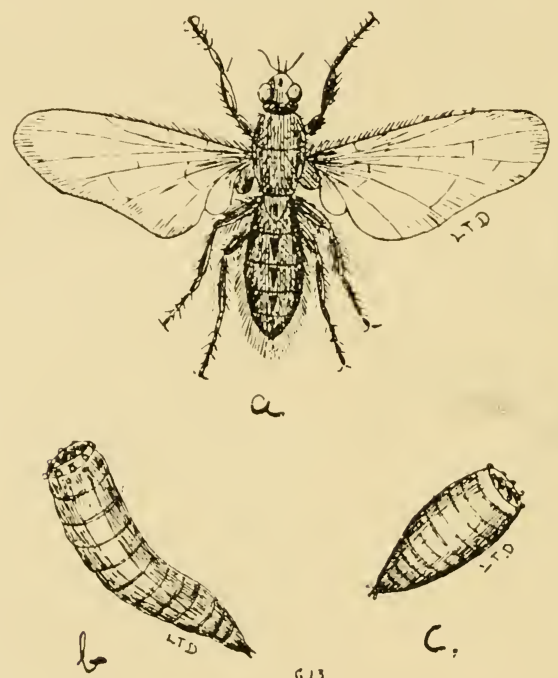

6,3

THE ONION FLY (ANTHOMYIA CEPETORUM). $a$, Perfect insect; $b$, Larva ; $c$, Pupa.

Onion FIy (Anthomyia ceparum).--Much mischief is done to onion, shallot, and garlic crops by the grubs or maggots of this fly. The flies deposit their eggs on the young onions in May, June, and July. The eggs speedily hatch into maggots, which at once commence to bore into and feed on the bulbs, and cause them to decay and the foliage to turn yellow. The maggots feed for about a fortnight, and then leave the bulb and turn into pupa in the surrounding soil. In from ten to twenty days 
(in summer) the flies appear, and begin to lay another lot of eggs, so that bulbs previously uninjured are exposed to an attack. The grubs are white, legless, half an inch long, with a pointed head and a broad tail.

Remedies. - All the plants affected should be carefully lifted with a trowel and burnt. Immediately each infested plant is dug up pour a little paraffin in the hole to kill any maggots that may have escaped from the bulbs. Unless this precaution be taken the maggots will speedily find their way to the next healthy plant. Do not grow onions on infested ground for a season. Other preventive measures are sulphur-half an ounce to the yard-sown along the drills at the time of sowing the seed; or salt and soot - a peck of each mixed to a bed $30 \mathrm{ft}$. by $6 \mathrm{ft}$.— sown broadcast a day or two before sowing the seed, supplemented by light sprinklings-quarter-peck-at intervals of three weeks, choosing showery weather, if possible. Undoubtedly, the best of all remedies is to dress the ground in autumn, or before sowing, with one of the soil fumigants advised for Millepedes.

Pea and Bean Thrips.-Although but little is known about the various species of Thrips, it is very evident that considerable damage results among crops and greenhouse plants by their depredations. In vegetable gardens onions, cabbages, runner beans, peas, and potatoes are all subject to the attacks of the various Thrips, whilst under glass we find a common example in the Black Fly, so frequent on cinerarias. It is often found that the peas grow away well, and produce abundance of vigorous haulm and plentiful racemes of flower buds; but, instead of these opening into blossom, they shrivel up, become a twister, shapeless bundle of petals, and then fall off, leaving nothing but the short petiole where a young pod should be. This is due to the Thrips larvae, and also to the adult insects eating the pistil, stamens, and pollen within the unopened blossom, thus preventing the food from forming. 
The Scarlet liumner Bean 'Thrips is another common variety, doing great damage among the runner beans, and attacking the buts and blossoms in the same way as the Pea Thrips do on the pea crops. The Rumner Bean Thrips was described at considerable length in a number of the "Joumal" of the South-Eastern Agricultural College, and was stated to be quite distinct from the Pea Thrips. "The attack is discernible at first," savs the writer, "on examining the blossoms; later on, still more so by the complete barrenness of the rumners-a few flowers only. and here and there a dwarfed pord being seen. The lower petals first show signs of disease, becoming more and more shrivelled, until they are reduced to a mere crumpled mass; then the upper part of the blossom gradually dics away. Sooner or later the flowers fall off from the top of the flower-stalk, leaving the petioles attached to the stem, looking just as if the bloom had been severed by a sharp linife." The female of the Scarlet Runner Bean Thrips is about one-sixteenth inch in length, the colour is almost black or dark brown, a few hairs are on the joints of the body, the wings are of a dull white with three rows of spines, and the legs are deep yellow-brown. The larve are of an orange colour, and the pupe are very like them, only paler in colour and with small wings.

Remenes.-The Thrips shelter during the winter in the earth and under the bark of trees or poles, in the dried grass, and other like covers. It is imperative, therefore, after an attack to destroy all such winter shelters, pea and bean sticks, etc., and a different crop should be sown on the ground the following year. Where spraying is employed, when the foliage is attacked, nse Formula 14, or one ounce of prrethrum and one ounce of soft soap to eight yluats of water.

Pea Midge (Cecistomyia pisi).-The larve of this small inseret sometimes batily infest the young ports, feeding upon the peas, and cansing the pods to turn yellow. 
Remenr.-Pods foum of a vellowish colour should he examined, and if tiny white maggots are found within burn them.

Pea Moth (Endopisa proximana). - The reader will doubtless have found many a pod of peas with a maggot or maggots inside, and wondered how they came there. Well, the culprit is the larva of a small moth which lays its eggs on the young pods in June. When the young maggots appear they bore into the porls, and feed upon the seeds. When the larrae are fully grown they leave

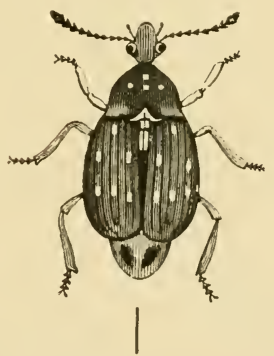

PE.I SEED WEETIL (BRUCHUS PLE).

Vertical line iudicates natural size.

the pods and descend to the ground to become pupar, emerging as moths the next season.

liemedy.-Ciather and burn all infested pods.

Pea Seed Weevil (Bruchus pisi). - A small weevil which deposits its eggs in the young pods. The larva bores its way into the seed, but it is not noticed until the latter has been harrested and stored, when its presence is noted by a hole in the seed through which it has escaped as a perfect weeril.

Remente---Practically none of any real service. Seed found infested shoukl be burnt. It is said that exposing the seerls to a temperature of 125 deg. Fahrenheit will kill the larvæ. 
Pea Weevils (Sitones lineatus, etc.).-These insects are very troublesome to pea crops in some seasons. The Striped Pea Weevil (Sitones lineatus) is probably the worst offender. It measures about a quarter-ineh or less in length, is of a light clay colour, with three whitish or ochreous stripes along its back, and several punctured stripes on its wing-cases. The horns and legs are of a reddish tint. The other kind, the Spotted Pea Weevil (Sitones crinitus), is smaller, of a grey or rosy colour, and spotted with black. These weevils crawl up the stems of the peas, and nibble holes in the edges of the leaves; in bad cascis devour the whole of the soft parts. In the larval stage they are found near the roots of clover and peas. They sometimes appear as early as March but chiefly in June and onwards. Beans as well as peas are liable to be attaclicd.

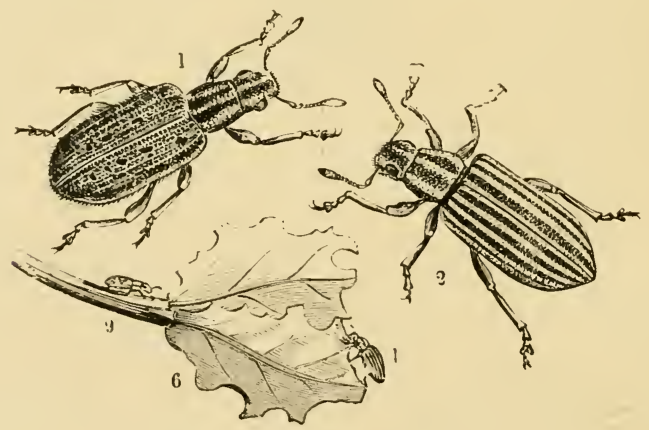

BELX AND PEA WEETLLS.

Fig. 1, The Striped Pal Weevil (Sitona lineata), nat. eize; 2, Ditto, magnified. Fig. 9, spotted L'ü Weevii (Sitona crinita), nat, size; Ditto, magnified.

Remenes. - When it is borne in mind that the weevils feed chiefly at night, and hide in the soil below by day, it will be seen how difficult it is to cope with them. Syringing the plants in the evening with Formula 14 will render the foliage distasteful to the weerils, and help to 
prevent injury. If the ground be dressed with one of the soil fumigants this pest will not prove very troublesome.

Radish Fly (Anthomyia radicum). - The larvie of this fly, which are yellowish-white in colour, fleshy and wrinkled in their bodies, legless, pointed in front and blunt behind, attack the roots of the radish and cause them to rot. Fortunately, they are not very numerous. The larva of other species of the same genus also feed on the roots of radishes.
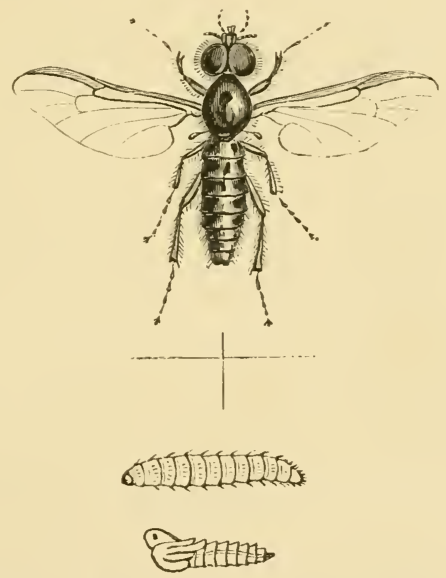

ST. MARK'S FLY (IMAUJ, LALTA, IND PLI'I).

Remedies. - Where the crop is known to be attacked water the soil once a week with the following solution: Add a quarter of a pint of crude carbolic acid and a quart of soft soap to a gallon of boiling water. Mix thoroughly, then add this to 25 gallons of water. Dress the ground also with one of the soil fumigants.

Root Aphis (Trama troglodytes). - This is a yellowishwhite, transparent insect, with a hairy body and a woolly 
extremity. It is occasionally found on the roots of the Jerusalem articholie.

Remenies. - If the crop be infested with these lice do not plant any more tubers on the same plot for a year or two; meanwhile dressing the land with one of the soil fumigants.

st. Mark's Fly (Bibio Marei).-The latter is a dipterous, or two-winged, fly, the actual size of which is shown by the cross lines at the base of the illustration. It is popularly known among entomologists as the st. Mark's Fly (Bibio Marei), and has not hitherto beeks: garded as a serious enemy to crops. The flies lay eir eggs on dung heaps, and from these hatch the hairy d ve of the size shown in illustration. When the manire is spread on the land the larvie attack the conto of ${ }_{1}$ lants, somewhat like those of the Crane Fies.

Remedies.-Manure found to contan these grubs should be sprearl out thinly and sprinkled with salt or slaked lime before adding it to the garden.

slugs and Snails. - Both do a reat deal of harm in the vegetable garden, especially amng seedling endive, lettuce, and peas.

liemedies.-Frequent dustings of me and soot will do much to protect the seedlings, butindoubtedly the best plan is to place heaps of bran a fer feet apart overnight. near the seedlings. The snails and lugs will quickly find these, and may be found congregat thereon next morning. The slugs and snails should ren be collected and thrown into a strong brine pickle. row of sawdust along each side of a row of peas will prent slugs reaching the latter. Sprinkling the surface, the soil with a solution of Clift's Liquid Insecticide, oligging in one of the soil fumigants, will keep slugs andnails at bay.

Thrips.-There are few insectnore destructive than these. The one which attacks ucumber plants is Heliothrips hamorrhoidalis, a da-brown four-winged 
msect, with a reddish-tipped body, pale yellow eyes and limbs, and measuring one-twentieth of an inch in length. It is wonderfully agile in its habits, jumping away directly the leaf it is on is touched. The larve, small whitish or yellowish maggots, are also fairly active, but they cannot jump. Both feed on the surfaces of the leaves and shoots, sucking out the juises, and causing them to assume a yellowish tinge and die.

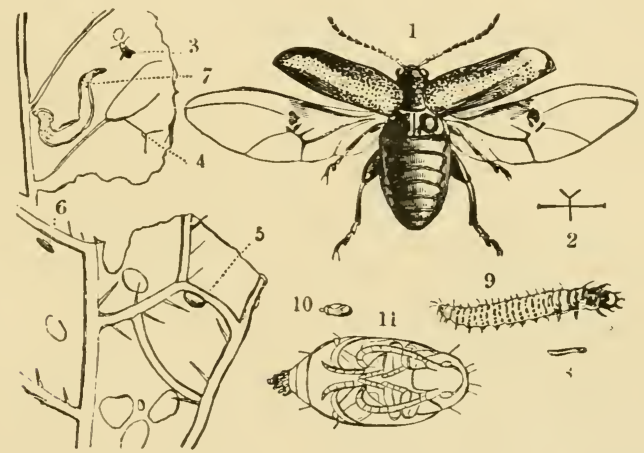

TCRNIP FLEA BEETLE (PHYLLOTRETA NEMORTM).

Fig. 1, Beetle magnified; 2. Lines to show nat. 6ize; 8 and 9, Larva, uat. size and magnified; 10 and 11 , Pupre, nat. eize and magnified; 5, etc, leat attacked.

Remedes.-Sponging, or syringing, or spraying the foliage with a solution of one of the advertised insecticides are the usual remedies. Fumigation with a nicotine preparation on three successive evenings generally proves successful.

Turnip Flea (Phyllotreta nemorum).-The Turnip Fly, or Flea Beetle, is a small beetle about one-eighth of an inch in length, dark in colour, and with two white stripes down its back. It is an active little creature, and springs a gool distance when disturbed. The beetles attack the seedlings directly they appear above the ground, 
riddling the stems and leavers with holes and destroying the plants. They do most harm on light soils and in dry seasons. When very numerous they will destroy the whole crop in a few days.

Remenes.--The chief point to bear in mind is to encourage the seedlings to make vigorous growth from the first. This can be accomplisher by the use of the artificial manures advised for turnips. The beetles will not interfere with the seedlings after they have formed their rough leaves. Other remedies are to fix some tarred sacks or sheets to a roller and then draw this over the ground.

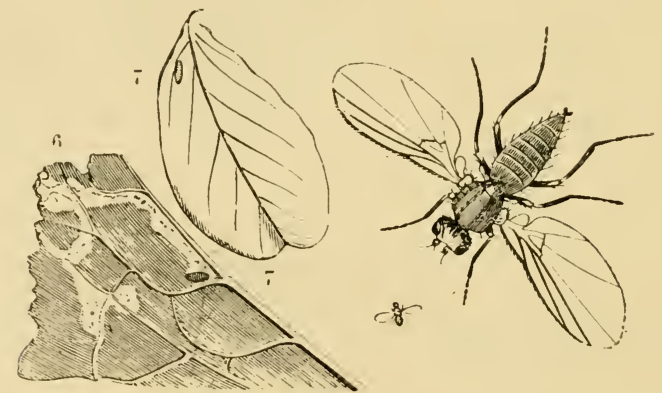

TURAIP LEAF-MINER (PHYTOMYZ.I NIGRlCORNIS).

Fig. 7. Under side of turnip ?eaf minet by the larve of the fly (Fig. 8, largely magnitied); 7 , lupa in the aaf; $b$, Nat, size of fly.

This will piek up a very large number of the beetles. Dust. ing the plants with lime or soot early in the morning whilst the seedlings are moist with dew is a good remedy. Weeds, such as charlock, ete., should not be allowed to grow in the fields, as these form a harbour for the beetles.

Turnip-leaf Miners (1)rosophilia flava and Phytomyza nigricornis) are the grubs of two flies which feed upon the soft tissues of the leaves of the turnip. The Irosophilia is about one-tenth of an inch long, of a yellow colour, while its larvie are green, and live beneath the skin on the upper sides of the leaves. The Phytomyza is also 
about one-tenth of an inch long, but has a black body and slate-coloured wings. Its larve burrow beneath the surface skin on the under side of the leaves.

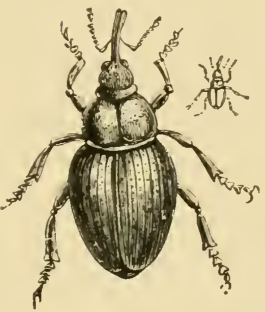

TURNIP GALL WEETIL (CELTORHYNCHUS SULCICOLLIS).

Nat. size and magnified.

liemedes. - The remedies for these pests are identical with those suggested for the Parsnip Fly, which see.

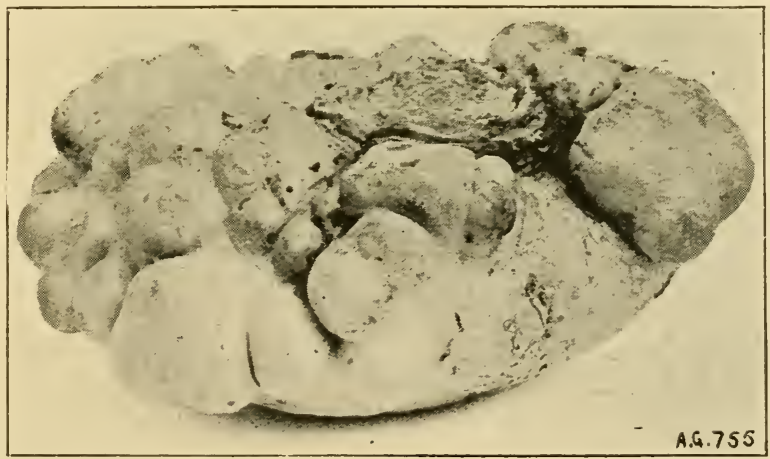

[Fhoto: H. 1. :mitli.

lOOT OF TLRNIP INFESTED WITH G.ILL GRLB.:

The root has been deformed by the larva of the Cabbage Root Gall Weevil feeding witkin.

Turnip or Cabbage Gall Weevil (Ceutorhynchus sulcicollis) is a beetle which attacks the roots of the turnip and the cabbage. It is about a quarter of an inch long, 
and has two antemne, or iecless, one on each side of the suout. The female beetle punctures the roots and deposits an egg in the wound. After hatching, a yellowishcoloured maggot lives, feeds, and grows to maturity within the turnip root, and thereby causes a gall-like excrescence on the turnip. The larve, or maggots, are transformed into pupa in the soil. where they remain about a month enclosed in "earth cases." The perfect insect is black,

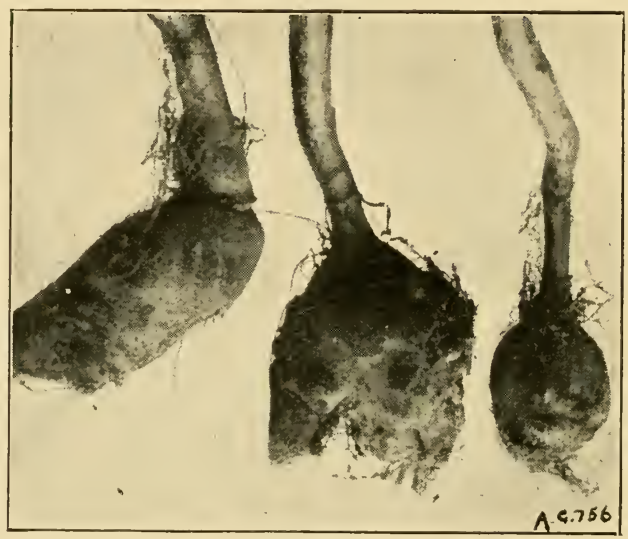

[l'hoto: H. A. Smith.

OABBAGE ROOT GAJL.

The maggots of a weevil (Ceutorhynchus sulcicollis) punctures the roots of turuips and eabbages and causes them to become swollen ae shown.

and the elytra, or wing-cases, are marked with a number of dots and stripes. The galls formed on the roots are often mistaken for the "Club Root," " Finger-and-Toe," and "Anbury" disease.

Piemedes.-. In the first place, pull up and burn immediately every infested root. Secondly, when the crop is cleared, dress the land with one of the soil fumigants advised for the C'elery Fly maggot. 
Turnip Saw.Fly (Athalia spinarum).-The female insect, by means of its oripositor, or organ which aids in the laying of eggs, cuts small slits in the leaves of the turnip plants, and in each slit lays an egg. The female Athalia lays from two to three hundred eggs in a season. The eggs are hatched in from four to ten days. The black larvae (known as "Niggers") feed upon the leaves of the infested plants, which they reduce to mere skeletons of fibres. In about twenty-one days the larve retire to the ground, where they spin cocoons, in which they are transformed into pupie. In about three weeks the perfect

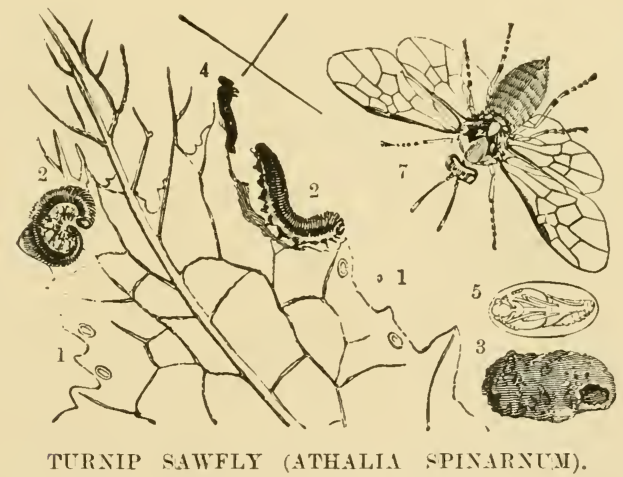

1. Leaf attacked by larræ; 2 , Larvæ; 3 and 5 , Pupæ; 7 , Sawfly olightly magnified.

insects appear, but if the pupa are formed late in the season they pass the winter in the cocoons already alludal to, turning to the perfect state in the following spring or early summer. The perfect insect is a black-and-yellow fly, with short feelers or antennie.

Remedies. - A new birch broom or a few small boughs tied together and drawn over the rows of plants will dislodge the larva. Once detached from the leaves, the larve appear to have no power to regain their pasition on the foliage. Spray the foliage with "Abol" Wash or 
C'lift 's Liquid Insecticide to destroy the caterpillars, and dress the ground with a soil fumigant to kill the pupar.

wireworms. - The IVireworn is a most destructive pest to tap-rooted crops. It is the larva of an insect called the Click Beetle. There are several species-Flater (or Agriotis), obscurus, lineatus, and sputator. So far as their hurtful properties are concerned, there is no distinction between them. The parent beetle is a greyish or blackish insect, about half an inch long, and may frequently be seen on plants during the summer. The beetles lay their eggs on the ground or at the base of plants. In due course

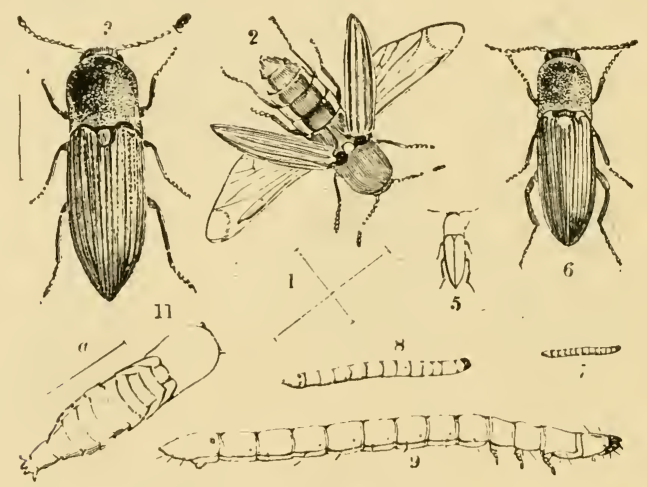

TRUE WIREWORMS.

Here are shown the True Wireworms or larve of the Click Beetle. The Iarva have only six legs in front, and are easily dirtinguished from the lli:lepedes, or False Wireworms, also the Centiperles, which have numerons legg, shown in the other illustrations. Figs. 1 and 2. Elater lineatns; Figs. 3 and 4, F. obsellrus; Figs. 5 and 6, E. sputator, natural size and magnified; Fig. 7, Larva of F. eputator; Fig.s. 8 and 3, Larva of E. lineatus, natural size and magnified; Fig. 10, P'upa of Wireworm; Fig. 11, Line ehowing natural length.

grubs are hatehed, and these straightway bore holes into the roots or stems of plants. Arlult grubs are easily recognised by their slender, wire-like, jointed bodies, yellowish colour, and slow movements. Wireworms are said to exist four to five years in the grub state, consequently their opportunities of injuring crops are extensive. 
Remenies.- Old pasture land and gardens that have been allowed to become neglected are liable to be badly infested with Wireworms. Heaps of rubbish, too, are favourite haunts. Newly-broken-up or neglected land ought to be dressed with gas-lime three months before crops are sown or planted. Dressings of Apterite, Clift's Powder Insecticile, Kilogrub, or Vaporite, liberally applied, will in time exterminate both larve and pupe. Soil for potting should be carefully examined before using, picking out the pests by hand. Salt, too, should be freely sprinkled among garden rubbish placed in heaps to decay.

woodlice (Oniscus armadillo). - These creatures sometimes do a great deal of injury to mushrooms, and to the fruits of cucumbers grown in frames. They have been known to attack young tomato plants.

Remenies.-Being night feeders they are difficult to detect. As they congregate, when not feeding, among rubbish and in crevices of walls and floors, their numbers may be considerably reduced by pouring boiling water cn the rubbish and walls. Traps, consisting of dirty flower-pots half-filled with mosis and laid on their sides, and potato tubers or mangolds with their interiors scooped out, form an excellent means of eatching Woodlice. Beetle poison spread on bread and butter and laid about the beds will lure them to destruction.

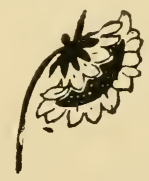




\section{VEGETABLE DISEASES.}

Artichoke Leaf spot (Ramularia cirera).-This is a fungus saicl to be the cause of the leaves of globe artichokes becoming spotted and dying, and the plants consequently prevented from producing flower-heads.

liemedies. - Ire know of none, and can only suggest burning infected foliage to prevent the disease spreading.

Asparagus Rust (Puccinia asparagi).-This fungoid disease has committed terrible havoc among the asparagus crop, especially in the Evesham district. It attacks the plants late in the year, and causes the shoots to turn black. The disease seriously weakens the growth of the plant, and ultimately liills it.

Remedes. - Spray the foliage every ten days during the summer with the Woburn Bordeaux Emulsion (Formula 21), or the ordinary Bordeaux Mixture (Formula 20); this acts as a certain preventive against attack. In the event of plants being infected the proper remedy is to cut off the foliage and burn it.

Bean-Pod Canker.--The pods of runner and kidney beans are now and then attacked by a disease which appears in the form of dark-coloured specks encircled by a redrlish line. These spots increase in size, form depressions in the surface, and eventually become covered with a white fungoid growth. The disease often appears on the stems, and when it encircles the latter the upper part of the shoot dies. Beans so attacked are worthless for fond. 
Remerien.-Bum infected plants and pods. Do not save seed from infected plants. Spray the plants before flowering with Bordeaux Mixture (Formula 20 or 21) half its normal strength, and, when the pods appear, with a solution of one ounce of sulphide of potassium to four gallons of water as a preventive remedy.

Bean Rust (Uromyces Fabre).-This fungus develops on the foliage and stems of the broad bean, covering them with a rust-coloured powder. If very prevalent the crop is seriously injured in consequence.

REMEDY.-There is none, but after the beans are gathered the stems should be collected and burnt, to destroy the resting spores.

Beetroot and Mangold Rot (Spherella tabifica). -A minute parasitic fungus, which first attacks the leares and then the roots of the beet, mangold, and potato. It has only recently been discovered to attack the latter crop.

Remedies. - (1) Avoid growing above crops on the same plot for five or six years after an attack. (2) Burn all infected roots and leaves. (3) Dress plots with gas-lime in autumn.

Beet Rust (Uromyces betre).-The foliage of beet is sometimes badly attacked by a rusty mould which seriously cripples the growth of the plants. The fungus first shows itself in the form of minute cups with whitish edges and congregated in clusters on the surface of the leaves. In due course these develop into a blackish-brown rust or miould.

Remedies. - The best remedy is to spray the foliage with the Woburn Bordeaux Emulsion (Formula 21), or ordinary Bordeaux Mixture (Formula 20) in June. When only a stray leaf here and there is attacked pick it off and burn it. When the crop is lifted, all infected leaves should be burnt, not left on the ground to rot or given to pigs, otherwise the fungus will reappear the next season. 
Black Rot of Cabbage (P'seudomonas campestris). -This discase has only recently made its appearance in England, but has been prevalent in America for some time. Its presence is indicated by the dwarfing or onesided growth of the plants, and by the heads rotting off. stems infected have a dark or brown ring in the centre, and the edges of the leavos turn brown. The disease is caused by a yellow bacterium.

Remevies.-Burn every infected plant promptly, dress the vacant land with gas-lime, and do not grow any of the cabbage family on the same plot for a year or two.

Cabbage White Rust (Cystopus eandidus). -1 fairly common fungoid disease on cabbages and cther plants of the same order. It appears in the form of swollen, white patches, or irregular masses of snow white powder. The effect of an attack is the distortion of the leaf and the ill-health of the plant. It is distinct from the Cabbage or Turnip Mildew (Oidium balsamii) which covers the surface with a white film of mycelium similar to hoar frost.

Remedy.---There is only one, and that is pulling up and burning every infected plant, so as to stamp out the disease.

Canker and Rot.-The cankery patches and rottenness of various roots are caused by wet seasons, sour and very heavy soils. There is no known remedy for these defects.

Carrot Disease (Phoma sanguinolenta). $-\lambda$ fungoid discase which attacks both the stem and the root of the carrot, causing sunken canker-like spots to form on the latter. Wherever the stems are to be seen coated with a minute mould, or the roots detected with sunken greyish-brown spots, it may be safely assumed that the disease is present. 
Rexenr.--So tar the only known remedy is to burn every infected stem or root, so as to destroy the fungus and prevent its reappearance another season.

Celery-Leaf Blight (Cercospora apii). - A fungoid disease which attacks the foliage of celery in wet seasons and causes pale spots to form thereon.

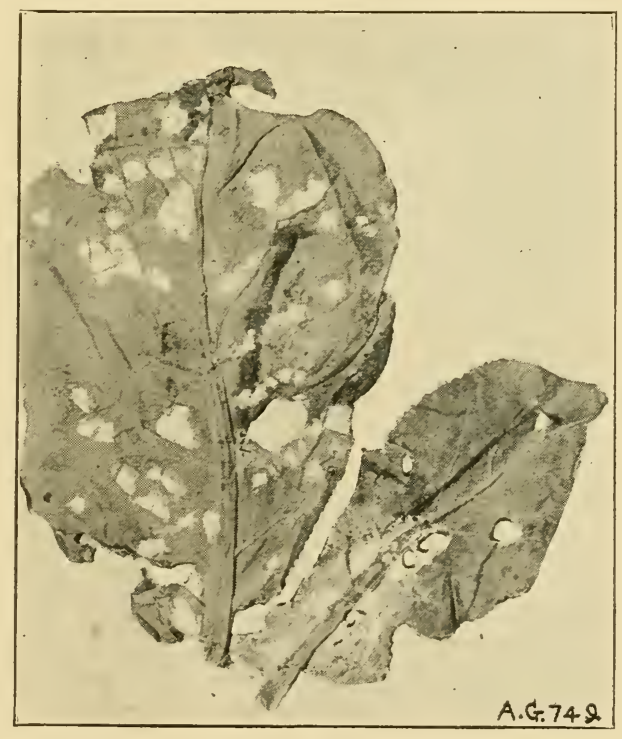

[Photo: H. A. mith.

C.ABBAGE WHITE RUST.

The white patches are the parts attacked by the fungus.

Remedies.-Once the plants are attacked the only remedy is to burn the infected foliage. Spraying with a Carbonate of Copper Solution (Formula 22) early in the season will prevent the fungus attacking the foliage.

Club Root.-The rlisease which causes the roots of turnips, cabbages, and allied plants, also wallflowers, to 
become distorted is commonly known as "Finger-andToe," "Club Root," and "Anbury." It is caused by a minute organism which finds its way into the cells of the

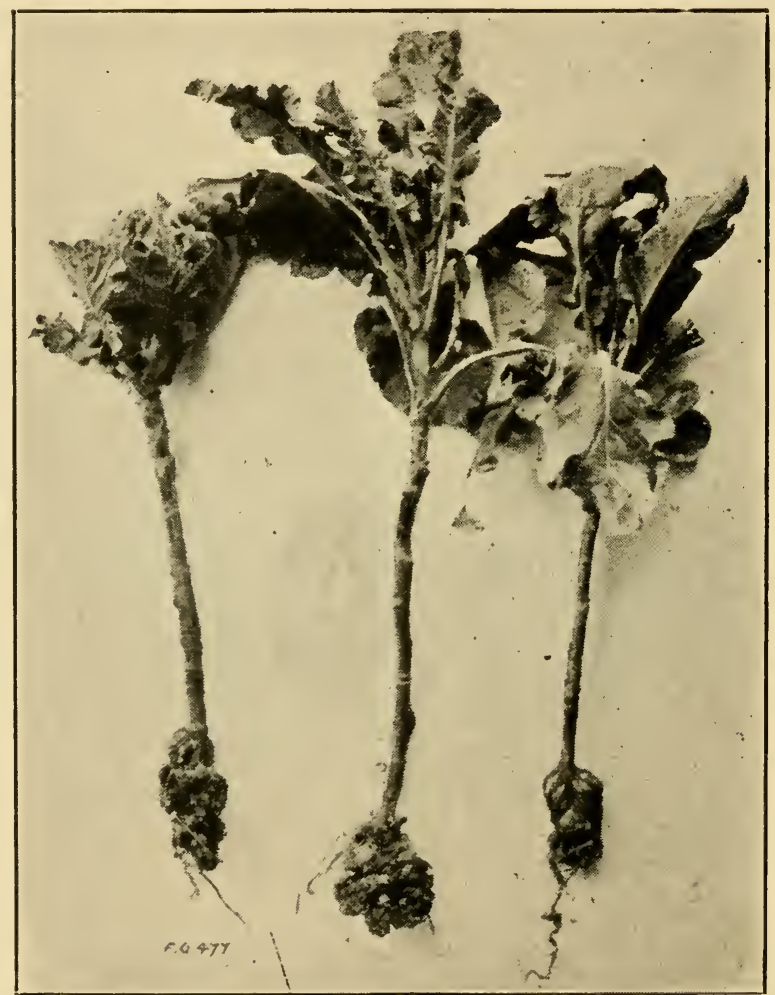

OLUB ROOT DISEASE (PLASMADIOPHORA BRASSIOE).

This disease, which is also known as "Finger and Toe" and "Antury," attacks the roote of cruciferous plants generally.

roots, and then develops, fracturing the delicate tissues and causing them to become putrefied. The name of this organism is Plasmodiophora brassicae. It belongs to the 
Myxogastres or Slime Fungi family. At one time, according to Mr. George Massee, the greatest living authority on plant diseases, the Plasmodiophora was considered to be a fungus, but now it is thought by some to belong rather to the animal than the vegetable kingdom. Unlike the fungi, it does not produce mycelium, but other bodies, capable of a sluggish movement, which unite to form a jelly-like substance, called a plasmodium. In due time the latter ceases to produce any movement, and then the jelly-like mass develops into spores. These spores escape from the roots into the soil, and there wait until the roots of a plant come in contact with them; then they enter by the spongioles, and are absorbed with the food into the cells. Once in the cells the spores begin to gerninate, and to move about until they meet and coalesce, as already mentioned. The mass of organism increases in size, and either bursts the cell-walls or causes them to bulge out, so that in time the warts or protuberances called "Finger and Toe" are largely dereloped. If the inside of a turnip or cabbage root deformed be cut open, the interior will be found to consist of a more or less black, slimy substance, offensive to the smell. This is the disease.

Remevies.-First of all, pull up and promptly burn every infected root. If thrown on one side to decay, or given to the pigs to eat, the spores will in due course be transmitted to the soil, ready to attack the first lot of roots placed in the ground. Plots or fields containing crops infected with "Finger-and-Toe" should not be planted again with the same kind of crop for several years. Land intended to be cropped with turnips or any of the cabbage family should be dressed with ground lime at the rate of 1ewt. per twelve square yards of land. Lime destroys the spores, and does the soil good at the same time. Broken chalk may be used instead of lime, at the rate of 10cwt. per square rod. It should be applied in autumn. In the cultivation of the turnip and the cabbage family avoid the use of sulphate of ammonia and super- 
phosphate, as the sulphur in the one and the acid in the other promotes the development of the disease. Cabbages should be raised in beds heavily dressed with lime.

Cucumber and Melon Mildew (Plasmopara cub)ensis).-This fungus attacks the under sides of the leaves of cucumbers and allied plants in the form of a white mould or mildew. It sprearls rapidly, and consequently soon spoilis the crop. Not a very common disease.

Remeniss. - Where only a single leaf or so is attacked remove and burn them. As a preventive, spray the under sides of the leaves with the Woburn Bordeaux Emulsion (Formula 21) or ordinary Bordeaux Mixture (Formula 20).

Cucumber Fruit Rot (Gloesporium lagenarium).-I fungoid disease which attacks the ends of the fruits, causing them to become rotten. The leaves and stems are also liable to be attacked.

Remeur.--None is known. The only thing to do is to cut oft all diseased fruits and burn them.

\section{Cucumber-Leaf Spot (Cercospora melonis). -} Although this was first observed as recently as 1896 it has s reard so rapidly as to be at the present time the most ilestructive parasite with which the cultivator of eucumber's an!l melons has to contend. Many market growers have been obliged to give up the cultivation of the crops, whilst other's report a loss of $£ 2,000$ annually. The first symptom is the appearance of pale green spots scattered about on the surface of the leaves. These spots gradually sread until they run together, and at the same time pass through a grey to a brownish colour. This is the fruiting stage of the fungus. If it be examined at this time with a lens it is found to consist of a lot of fine, upright, brown threads, cach bearing a fruit or "conidium" at its tip. These conidia are the reproductive bodies, and can be carried from disedsed to healthy plants on currents of air, 
clothing, or insects. Sometimes the leaves dry up and fall to the ground, when the " mycelium" present in the tissues quickly grows, forming cobweb-like threads, which

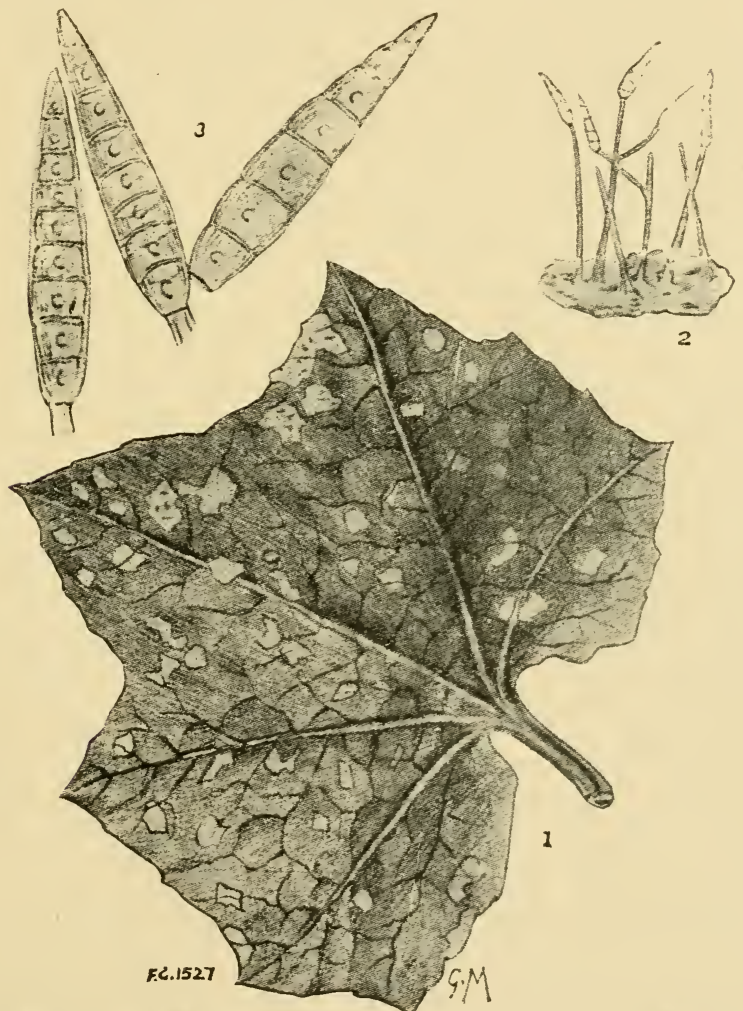

CUCLMEER AND MELON LEAF BLOTUH (CERCOSTORA MELONIE).

1, Infected leaf; 2, Magnifed view of the fungus; 3, Fruit of the fungus. (itrom Board of Agriculture Leaflet.)

run on the surface of the soil, producing more conidia. Failing food, the disease passes into a resting state, in 
which form it may remain inactive in the soil from season to season, only to spring into life again on the advent of warmth and moisture. These latter conditions are absolutely necessary to the pest, and so it can only attack plants mider glass, attempts to inoculate plants grown cutside having failed. There is said to be no risk of infection from the seeds.

Remedies. - The foliage should be kept as hardy as possible by the admittance of plenty of air, and the atmosphere should not be kept any moister than is absolutely necessary. Spraying in anticipation, with a solution of two ounces of potassium sulphide in three gallons of water, adding two ounces of soft soap, is recommended. The under sides of the leaves should be carefully sprayed and the soil well drenched with the solution if the disease is present. Diseased leaves should be removed and burnt. After a crop has been taken out the soil should be soaked with a solution of Jeyes' Fluid-one ounce to the gallon of water-or Formula 11 be used.

Cucumber Mildew (Oidium erysiphoides). - A form of mildew or white mould which occasionally attacks the foliage of the cucumber and melon, forming white blotches on the surface. Plants attacked soon become sickly and fail.

Remedy.-Thoroughly coat the surface of the leaves with flowers of sulphur, applied by means of a sulphurator, directly the mould is seen.

Cucumber Rot (Hypochnus cucumeris). - A fungus which, in the form of a grey, film-like growth, attacks the stems of cucumbers near the soil, causing them to die.

Rexenies. - Rub a little lime on the base of the stems. Burning the infected roots and stems will prevent the disease spreading.

Lettuce Mildew (Bremia lactucx). - A minute fungus which covers the under surface of the leaves of let- 
tuce, chicory, and wild composite plants generally, with a fine white mould. In course of time the infected leaves turn yellow and die.

Remenies. - The safest remedy is to pull up and burn every plant infected. It would not be safe to spray the plants with fungicides, on account of the poisonous properties of the latter.

Mint Rust (Puccinia menthx).-This is a fungus which attacks the stems of mint and allied plants, causing them to become swollen and distorted, and utterly spoiling the crop from a market point of view. The fungus appears first in orange-coloured masses on the stems, and later on as blackish-brown powdery pustules on the leaves.

Remeny. - There is only one, and that is of a drastic character, namely, lift the infected plants and burn them. It is useless applying fungicides. Dress the ground afterwards with ground lime, and grow mint in a fresh plot.

Mushroom Disease.--Mushrooms are sometimes attacker in an early period of their growth by a minute parasitic fungus (Hypomyces perniciosus), the mycelium of which develops in the mushroom and causes the stem to assume a swollen, bulbous-like mass of growth. The infected mushroom consequently fails to grow properly, and the stem eventually changes into a putrid mass, emitting a rlisagreeable smell. The spores of the parasite are, no doubt, introduced into the mushroom bed with the spawn or the manure. Other diseases attacking the mushroom are the Tuft Mould (Gliocladium agaracinum), which causes mushrooms to crack and decay; and the Mushroom Mould (Mycogone alba), which distorts the gills and renders the crop unfit for use.

Revenies.-Any mushrooms which do not develop properly, or have swollen stems, with scarcely any caps or heads to them, should be removed and burnt. In the case of a severe attack, remove the whole of the manure and soil right away from the neighbourhood of the beds, and 
then spray the roof, walls, and floor of the mushroom house with a solution of one pound of sulphate of copper to fifteen gallons of water. The spraying should be done

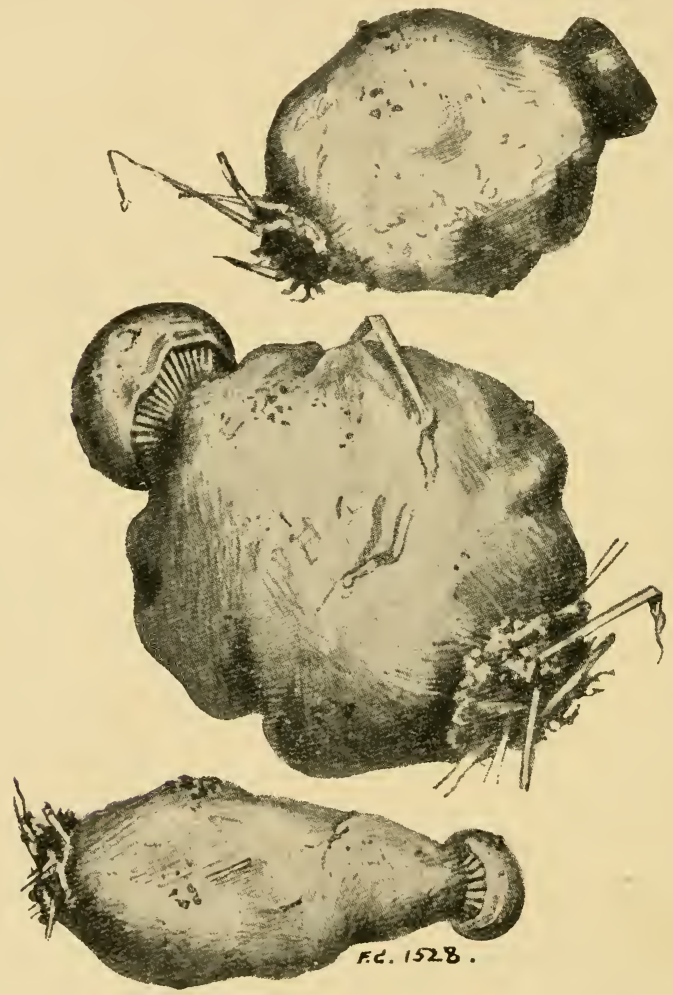

MUSHROOM DISEASE (HYTOMYCES PERNICIOSLS).

Canees mushroome to grow with swollen and distorted stems. [By permission of the Bcard of Agriculture.]

three times, at intervals of ten days. During this period keep the house warm and moist to encourage the fungi to grow and be more easily lilled by the copper solution. 
Onion Mildew (Peronospora schleideni).-A fungus which frequently does serious injury to the onion crop. It occuns in the form of a mould on the leaves. At first its presence may be detected by yellowish patches, followed later by a white, and then a greyish-lilac mould. The disease causes the leaves to shrivel and the growth of the bulb to be stunted.

Remedies.-Mix two parts of slaked lime with one of sulphur, and dust the plants early in the morning whilst the dew is on the foliage. Spraying the foliage with a solution of sulphide of potassium and water (Formula 23) is anothel good remedy. All diseased plants should be promptly burnt, and onions not be grown on the same land for three years.

Onion Rust (Puccinia porri).-This fungus attacks both onions and chives. It forms reddish-brown pustules on the leaves, and often destroys the whole crop.

Renedy.-The only course to pursue is to burn all infected foliage.

Onion Scab (Vermicularia circinians).-Fortunately not a very common disease. It appears in the form of small black velvety tufts, dispased in concentric circles on the vuter scales of the bulbs. These black patches disfigure the bulbs, and practically render them unusable. Generally speaking, the disease manifests itself most on fully-grown bulbs.

Remedies. - When storing the bulbs reject every one possessirig the faintest tinge of the Scab, otherwise the fungus will infect the healthy bulbs and spoil them. Diseased bulbs should not be left on the ground, but be promptly burnt.

Onion Sclerotinia (Sclerotinia bulborum).-A fungoid disease appearing in early summer in the form of yellow biotches on the leaves, followed by an olive-brown mould. The mycelium of the fungus eventually descends 
to the bulbs, and develops into a blackish mould which completely covers them.

Remenies. - Spray the foliage directly the yellow patche's appear with the Woburn Borkeaux Emulsion (Formula 21) or Sulphide of Potassium (Formula 23). When lifting the crop reject and burn every diseased bulb. In the case of

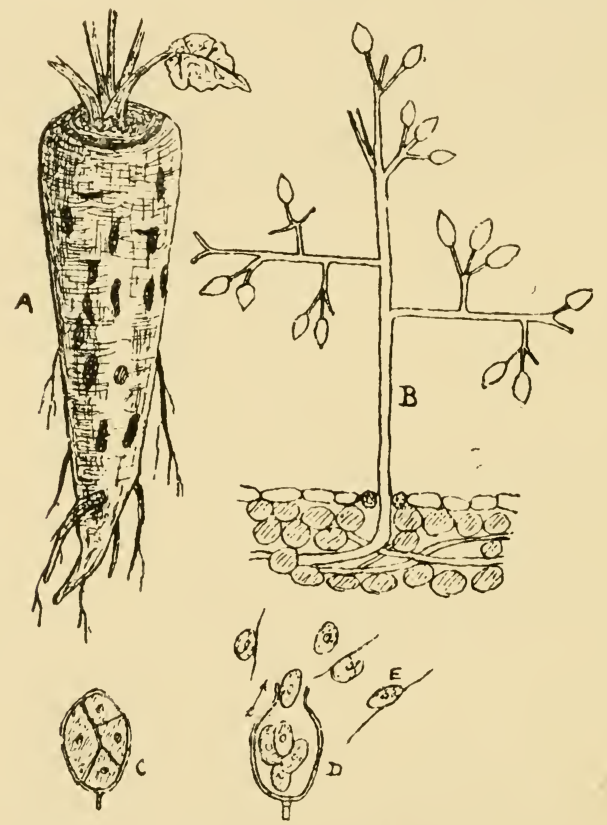

MILDEW OF PARSNIPS (PL.ISMASPORA NIVEA).

References: $a$, A spotted parsuip; $b$, Conidiophore bearing einioia (spores) $\times$ $1 \mathrm{CO} ; c$, Mature conidium dividing $\times 5 \mathrm{CO} ; \boldsymbol{l}$, Conidim after division, the formation of zoospores, $\times 500 ; e$, Zoospore with eilia, $\times 500$

¿ bad attack, do not grow onions on the same plot for three years.

Onion smut (Urocystis cepula).-This is a black mould (fungus) which attacks seedling onions and speedily 
kills them. At first the leaves are attacked, and then the bulbis.

Remedy.-The only remedy known is to pull up and burn all infected plants.

Parsnip Mildew (Plasmopara nivea).-The roots of parsnips are sometimes attacked by the foregoing fungus, which causes the former to become putrescent and unfit for food or sale.

Remedr. - All roots that show signs of going rotten should be promptly burnt, to destroy the fungus and prevent the latter spreading another season.

Pea Mildew (Erysiphe Martii). - A fungus, or mildew, which attacks peas very badly in some seasons, and practically ruins the crop. The fungus first turns the leaves of a yellow tint, then coats the surface with a fine white growth, similar to ordinary mildew. Soon after this dense coating becomes dotted with small black bodies containing the spores of the mildew. The disease is more prevalent in very dry or very wet seasons.

Remedies. - Spray with sulphide of potassium and water (Formula 23) if the mildew attacks the foliage only very shlightly; if badly, the best plan is to burn the plants.

Pea Spot (Ascochyta pisi).-A fungoid disease which attacks the pods of peas, causing pale spots to form on them and making them more or less deformed in shape. Not a serious disease.

Renedies.- Spraying with the Woburn Bordeaux Emulsion (Formula 21) if very prevalent; gathering and burning the infersted pods in isolated cases.

Radish Mildew (Peronospora parasitica).-Not a serious disease. It attacks the foliage in the form of a white mould or mildew.

Remedy.-Spraying with a Sulphide of Potassium Solution (Formula 48). 
Seeding Cabbage Disease (Olpidium brassicie). - I fungoid disease which attacks young plants of the cabbage family, causing the stem to droop and the plant to die. It appears to infect plants growing in moist positions only.

Rexenies.-Burn all plants that suddenly droop and die, and form the seed-bed in warm, dry positions only.

Seeding Pea Blight (Brachysporium pisi).-This fungus attacks peas in the earlier stages of their growth, forms black patches on the foliage, and causes them to die.

Remeny. - Spray with sulphide of potassium and water (Formula 23).

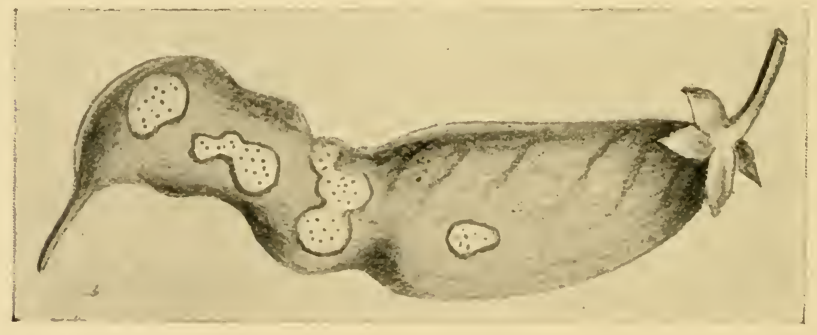

PEA SPOT (ASCOCHYTA PISI).

I diseace attackirg the pode of culinary and sweet peas.

Spinach Mould (Peronospora effusa).- I fungus which infests the under sides of the leaves of spinach and allied plants. It forms patches of greyish-lilac mould, and if allowed to remain will rapidly spread and destroy the crop. Fortunately, it is not rery common. Weeds like the Goase-foot (Chenopodium) should not be allowed to grow where spinach is cultivated, as the fungus is partial to this plant.

Remeny.-Collect and burn all infected foliage. 
Turnip Bacterial Disease. - A new disease attacking turnips has made its appearance in the North of England. Mr. IV. Carruthers, F.L.S., describes it thus: "In the worst cases the young leares had disappeared from the crown, or were rotting away; the outer, older leaves also showed signs of wilting; their stalks were decaying at the base, and a number of lateral buds were shooting up from the axils of these older leaves. As a rule, the outer skin of the turnip was intact. In some instances the top was as if scooperl out, and the depression lined by a whitish, slimy substance. In others injury had further penetrated to the base of the turnip, and the whole centre was a mass of rotten pulp. Even in the plants less seriously affected it was evident from the condition of the younger leares that they were being cut off from their connection with the root. Some of the turnips had wounds at the side or base, which formed starting points of attack, in addition to the injury at the top of the bulb. One or two wore suffering from 'Finger-and-Toe,' which was, of course, quite distinct from the rottenness that was destroying the turnips." A careful microscopic examination of leaf and bulb was made, and this revealed the fact that the injury was due to bacteria, which had gained access to the living plants between the bases of the young leaves or through the broken surface of the bulb. These bacteria were advancing into the substance of the turnip from cell to cell, destroying the tissues as they went. Sections were taken from the diseased parts and examined, and myriads of the bacteria were seen in the cells. The same bacteria (exceedingly minute, motile, cylindrical rods) were also found in the slimy substance from the cavity at the top of the turnips.

ReMeines.-As this disease has only recently been discovered, any remedies must be more or less of a speculative character. It has been suggested that the diseased turnips should be placed in layers, with quicklime between, then corered with earth and allowed to decay. The lime will kill the bacteria, and the decomposed matter 
may afterwards be used as manure. Another suggestion is not to grow turnips on the same land for several years until the bacteria has been starved out.

White Rust (Cystopus candidus). $-A$ fungus which attacks the foliage of radishes, eress, cabbage, and horseradish, callsing the partis affected to be distorted, and more or less snowy-white in colour.

Remedr.-Gather and burn every infected leaf. The fungus can only attack piants whilst in their seedling stage.

\section{CHAPTER III. \\ POTATO PESTS.}

\section{A. - INSECTS.}

Colorado Beetle (Doryphora decemlineata). $-\mathrm{A}$ pest of American origin. The female beetle is just under half an inch in length, the male being slightly smaller, and the colour is yellow marked with five longitudinal dark lines on each wing-case. The legs are red, and the wings of a rosy tint. The eggs are oval, orange in colour, and deposited in clusters of nine to forty under each leaf. The larve are of a dull reddish-brown colour, and about an inch long when fully grown. They feed ravenously on the foliage till they attain maturity, then descend and pupate in the soil. In America several broods are produced in one season. 'The beetles are very hardy, and survive the winter in the soil or among rough herbage.

liemenes. - Fortunately, this pest has not been seen in this country for many years, but if it should make its appearance it is well to remember that under the Destructive Insects and Pests Act, 1908, immediate notification thereof must be sent to the lncal inspector of the Board of Agriculture. See Chapter V., Part VII. 


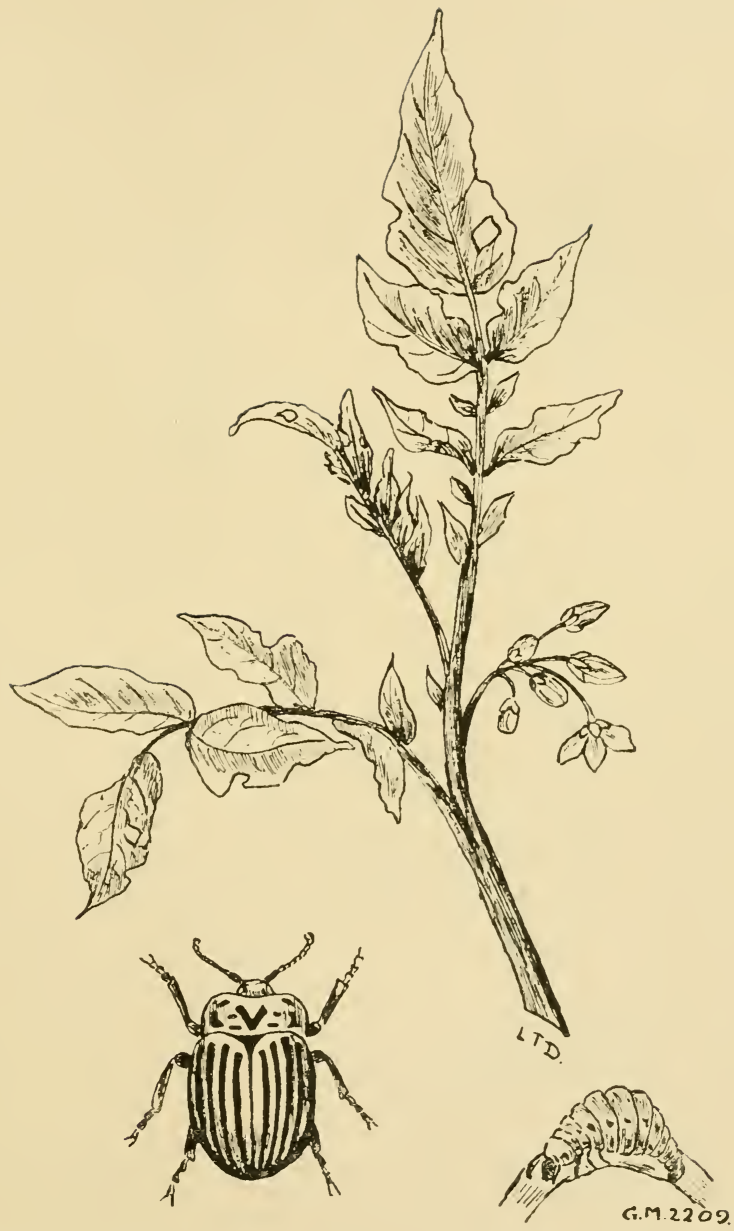

COLORADO BEETLE AND LARTA (DORYPHORA DECEMLINEATA) 
Potato Bug (Lygus solani). - Active little insects furnished with a rostrum, or beak, by means of which they puncture the leaves and feerl on the salp. They have

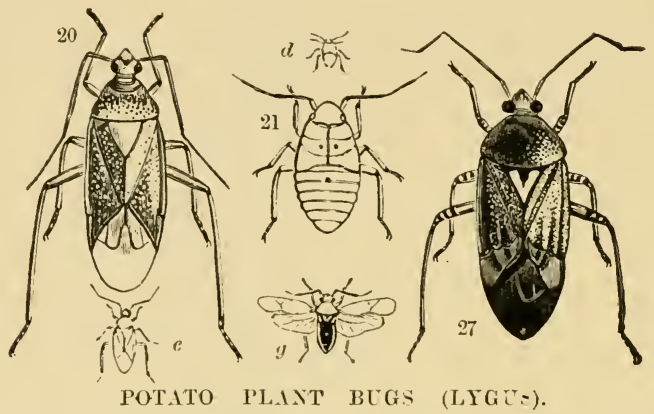

Fig. 20, L.ygus Salani, magnified; $c$, Na.t. size; 21, Larva etage magnifiel; d, Nat. size. 'ंig. 27, Lygus umbellatarum magnified; a, Nat. size.

green, shiming bodies, are most abundant in August, and do similar injury to the foliage as that done by the Frog Fly.

Remedr.-Same as for the Frog Fly.

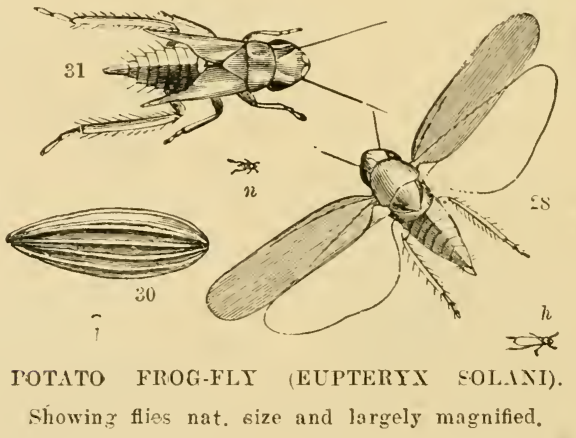

Pctato Frog FIy (Eupteryx solani). - A small greenish fly which may be seen hopping about potato foliage 


\section{PÓTATO PESTS}

in August and September. The flies suck out the sap from the leaves by means of a beak, or rostrum, and their small green larvie also pierce the cuticles of the leaves, feed on the sap, rupture the cellular tissue, and severely check the growth of the plants. The flies run to the opposite side of the leaf when disturbed, and also hop about when the sun is shining.

Remeliy.- Spray with an insecticide (Formula 11).

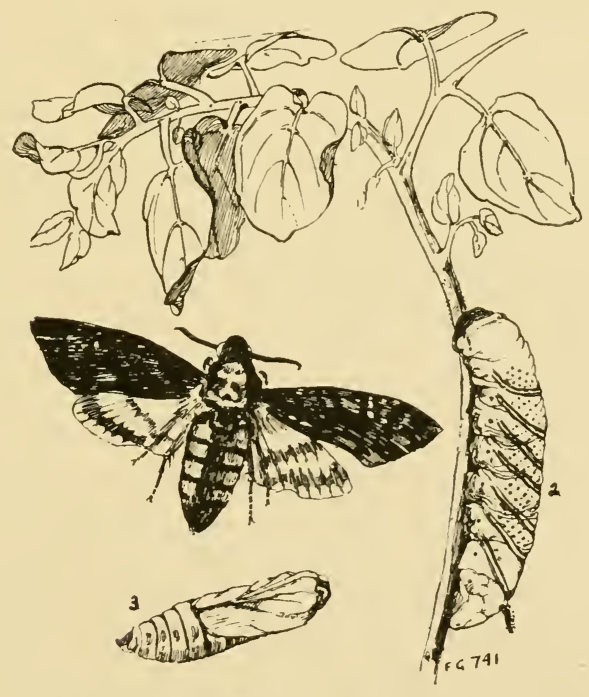

DEATH'S-HEAD MOTH (SPHIX ATROPOS).

showing moth, larra, and chryealis.

Miscellaneous Pests. - In addition to those already described in this chapter, the Wireworm, various Millepedes, the larva of sereral moths, as the Dart, Heart and Dart, Death's Head Moth, and Yellow Underwing Moth; also Slugs and Snails, all of which are dealt with fully in other sections of this work. 


\section{B.-DISEASES.}

American Potato Disease.-A fungoid disease said to have come from America attacked potato crops in this country a year or so ago. The fungus is said to be a species of Rhizoctonia, which covers the tubers with a purplish mycelium, and develops root-like sclerotia which penetrate the surrounding soil. The effect of an attack is to restrict development of the young tubers and produce a uiseless crop.

Remedes.-Burn all infected tubers and haulm. Dress the soil in winter with ground lime at the rate of 1 cwt. per twelve square yards.

American Potato Scab (Oospora scabies). - I dis. fase prevalent in America, but not common in England. It has a similar effect upon the tubers to the I'otato Scab.

limenes. - Authorities say that the presence of lime in the soil encourages the development of this disease; so that lime should not be used in the event of the disease attacking the crops. Steeping the tubers in the formalin solu. tion advised for the Potato Scab will destroy the fungus.

Black-leg, or stem Rot.-This disease is said to be causer by a bacteria (Bacillus phytopthorus). It causes the leaves to wilt and turn yellow, the stems to be covered with brownish stains, and eventually to become rotten. The disease is more active in hot, damp weather, and seriously affectis the value of late crops especially. Carrots, turnips, marrows, and mangolds are said to be similarly affected. The disease also affects the tubers.

lieventes.- Full up and burn infected hauln. Io not plant cut sets. Secure seed from a source whence the disease has not appeared. Lime, nitrate of soda, and sulphate of ammonia are favourable to sprearling the discase.

Leaf Curl. A fungoid disease which has long been prevalent in this country. It causes the foliage to curl at 
the edges, and later to develop mottled spots thereon; also to become stunted in growth. The disease may be conveyed by spores in the soil or floating spores in the air.

Remenies.-Burn all diseased haulm and tubers. Aroik planting sets containing red streaks in the flesh. Dress the soil with ground lime in winter, and sprinkle Kainit thinly along the drills at planting time.

Leaf spot.-A fungoid disease attacking the foliage late in the season, causing brown spots to form and these eventually to become dry and fall out, thus producing holes in the leaves. The effect is cessation of growth of the tubers and a light crop. Tubers not affected.

Remedies.-Spray with Woburn Bordeaux Fnulsion (Formula 21), as advised for Potato 1)isease, and burn all infected foliage.

Potato Disease (Phytophthora infestans).--This is the dreaded disease which commits so much havoc anong the potato crop in wet seasons. It first manifests itself in the form of brown patches on the leaves, followed by curling of the latter, and finally by their becoming blacki and decayed. The disease is caused by a fungus, the mycelium of which penetrates the tissues of the leaves and destroys them. In due course the mycelium develops what are technically known as conidiophores, or tiny stems which appear in the form of a mould on the surface. On the conidiophores are borne conidia, which give birth to zoopores. These, coming in contact with globules of water, emit germ tubes that penetrate the epidermis of the leaf or tuber, and eventually form the mycelium which does so much mischief to the tissues. The nycelium will often lie dormant in the tubers all the winter, and start into activity when new growth begins in the soil. The lisease is mostly prevalent in rainy seasons. The fungus also attacks tomato plants grown in a moist, stagnant atmosphere, the spores under such conditions easily germinating, followed by the development of thread-like 
growths, which penetrate the cells, destroy the chlorophyll, and cause the decay of the leaf and fruit.

Remedies.-Once the disease has made itself manifest the only remedy is to burn the infected haulm and tubers. On no account should either be allowed to lie on the ground or be given to pigs, as the disease will retain its vitality and reappear the next year. Nor should tubers from infected crops be used as " seed." Of late year's preventive measures have been adopted with great success. Spraying in good time-early in July, again about the middle of the month, and lastly at the end of the monthbefore the disease appears with the IToburn Bordeaux Emulsion (Formula 21), or the Mixture (Formula 20) is a sure and safe preventive.

Potato Rot.-Dry and Wet Rot of potato tuber's is said to be caused by two fungi, Periola tomentosa and Fusarium solani. The tubers in one case become rotten, although dry, and in the other wet and rotten. These diseases attack the tubers in the soil, as well as in the store.

Remedies.-Dressing the infected land with ground-lime at the rate of $1 \mathrm{cwt}$. per twelve square yards in winter will kill the mycelium present in the soil. All infected tubers should be burnt, not given to the pigs.

Potato Scab (Sorosporium scabies). - A fungoid disease which causes olive-coloured, scab-like eruptions of a superficial nature to form on the surface of the tubers, which render them unsightly. It has been found by experiment that tubers grown in sour soils, or where artificial manures containing acids, as superphosphates and dissolved bones, have been lavishly used, are most susceptible to infection.

Remenies. - Is a preventive of Seab, place the seed tubers in a coarse sack, and steep this for two hours prior to planting in a solution of formalin and water-half a pint of commercial formalin to fifteen gallons of water. After 
doing this, sprearl the tubers out to dry, then plant. Soils that are periodically limed are reputed to be less likely to promote the development of the disease. Sprinkling flowers of sulphur along the trenches before planting is also said to be a goor preventive remedy.

Sclerotium Disease (Sclerotinia sclerotiorum).This is a fungoid disease which attacks the stems of potatoes just above the ground. It is in the form of a white mould, which gradually creeps up the stems and

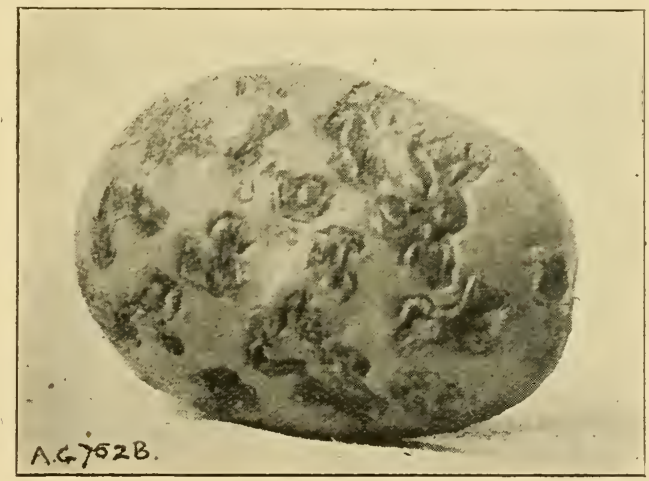

POTATO SCAB [Photo: H. A. smith.

This disease (Sorosporium scabies) canses olive-coloured scabe to form on the tubere.

develops into small black bodies called sclerotia. When the latter stage is reached the stem becomes limp, withers, and dies, seriously checking the growth of the tubers. In dry weather the white mould is not apparent on the outer surface, the disease being more active within.

Remedr.-All foliage showing any indication of the disease should be burnt, otherwise the disease will attack a future crop. It appears that beans, peas, marrows, cucumbers, and turnips are liable to be attacked also. 
Spindle Disease.-A fungoid disease is said to be the cause of potato tubers producing weak, spindly shoots in spring, and consequently refusing to produce new tubers.

Reveny. - The only remedy is not to plant tubers that produce spindly, weak growths.

Wart or Black Scab Disease.-This is a comparatively new disease, which has rapidly sprearl through-

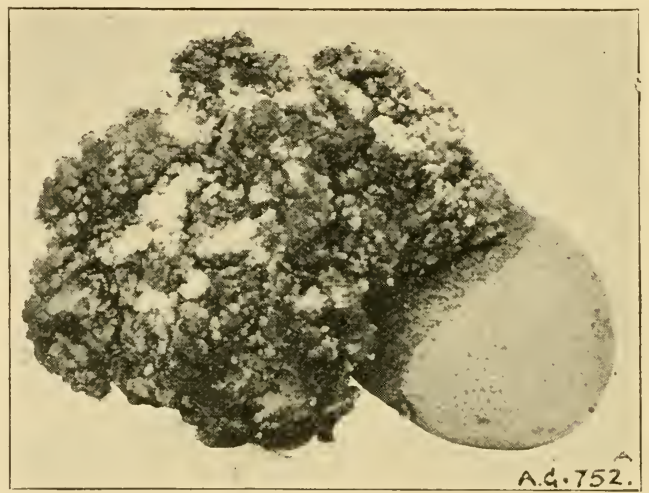

[Photo: H. A. Smith.

POTATO INFECTED WITH BLACK SCAB DISEASE.

The tuber has its one end distorted by a warty-like growth due to the action of the fung:is.

out the country, inflicting serious damage upon the potato crop. So serious, inteed, has it become the last year or so that the Board of Agriculture and Fisheries have, under the powers conferred upon them by the Destructive Insects and Pests Acts, 1877-1907, scheduled it as a notifiable diseases. The disease (Synchitrinum endobioticum) attacks the tubers in the first instance by means of spores. These give hirth to mycelium, which vegetate in the cyes of the tubers, and eventually produce black, spongy, 
wrinkled warts or scabs over the tuber, and render it quite unfit to eat. The same disease is said to attack beet and mangolds, and the spores remain dormant in the soil for several years.

Rembins. - It is the bounden duty of every grower who finds tubers covered with the black warts to send a specimen or two to the Secretary, Board of Agriculture, 4, Whitehall Place, London, S. IV., accompanied by his full name and address. The Board will then deal with the disposal of the'infected crop and advise as to treatment of the soil. Failure to report the disease renders tho grower liable to a penalty of $£ 10$. See Chapter V., Part I'II.

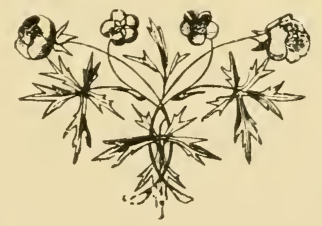




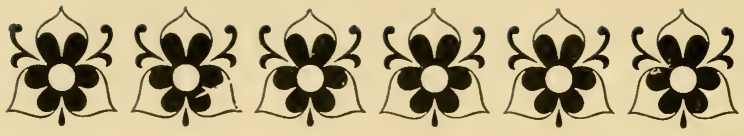

\section{Part IV.-FLOWER GARDEN FOES.}

\section{CHAPTER I.}

\section{INSECTS, MITES, $\mathbb{E}^{\circ}$.}

Ants, - These often prove very troublesome in borders and on lawns, owing to their throwing up heaps of soil and loosening the earth or turf.

Remedies. - The most practicable remedy is to find out their nests, make a hole a foot deep in the centre, then pour in half an ounce of disulphide of carbon, and immediately seal the hole with soil. The fumes will asphyxiate the ants. Repeat the dose a fortnight afterwards. Renember, the carbon is rolatile and inflammable, so do not smoke when using it. For getting rid of ants on walls add one part of carbolic acid to ten parts of water, and saturate the surface therewith.

Aphides.--Four species of $A$ phides infest flower garden plants. First of all, there is the Common Greenfly (Rophalosiphon dianthi), the Rose $\Lambda_{\text {phis }}$ (Siphonophora rosie), Swcet Pea Aphis (Sophonophora pisi), and the lioot Aphis (Trama troglodytes). The first three infest the shoots and leaves, sucking out the sap, crippling the growth, and sealing up the stomato of the leaves with a 
glutinous substance called honeydew. The fourth infests the roots and stems of the auricula. They are covered with a woolly down, and suck the sap out of the cells.

Revedies. - For the first kinds spray with a soap and Quassia Solution (No. 14), or with one of the advertised insecticides. For the Root Aphis lift the plants, well wash their roots in soapy water and replant in a fresh site.

Bulb Mite (Rhizoglyphus echinopus). - This is an almost microscopic creature, which feeds on the bulbr of tulips, lilies, and onions, and the roots of dahlias, potatoes, vines, eucharis, etc. Their presence may be detected on plants by small reddish scales on the bulbs or roots, and by the pale yellow colour of the foliage. They can only be seen by the aid of a powerful lens.

Remedies.--(1) T'he most effectual remedy is to burn all infested bulbs and the soil they have been grown in. Wash the bulbs, before planting or potting, in a solution of sulphide of potassium and water (one ounce to three gallons). (3) Fumigating in a closed chamber with bisulphide of carbon. Use one pint of carbon to 1,000 cubic feet of space. A dangerous remedy, however, as the gas is highly poisonous, and must not be heated. Nor must a light of any lind, not even a lighted cigar, cigarette, or pipe, be used near, otherwise the gas will ignite and explode.

Carnation Maggot.-The carnation maggot is a terrible foe. Fully grown, it measures about one-third of an inch in length, and is of a yellowish-white colour. Its parent is a small fly, named Hylemia nigrescens. This fly deposits its egg or eggs in or on the leaf, and these sulosequently hatch into maggots an eighth of an inch in length, which eat their way just under the skin of the leaf to the centre of the shoot. Here they feed on the pith, and consequently kill the plant. Their presence in the leaves mav be detected by thin whitish lines or streaks 
caused by the maggots eating the parenchyma, or inner tissue, and leaving only the outer shin.

Remenies.- If you see any of these lines in the leave's examine them carefully with a magnifying glass. If the larvie are present they should be removed with the point of a darning-needle or penlinife. If no larve are seen, and the shoot appears to be withering, pull out its point and slit the stem open, when one or more maggots may postsibly be found in the pith; if not, slit the other portion of the stem until the culprits are found. The parts removed,

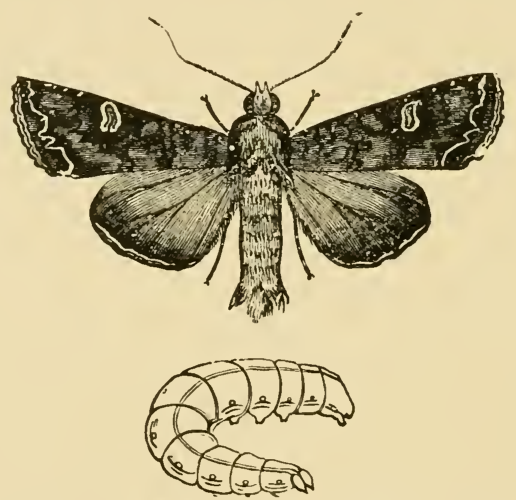

CABBAGE MOTH AND CATERPILLAR.

The larva feed on geraniums, dahlias, etc.

together with dead plants, should be immediately burn to destroy the eggs, larve, or pupa that may have escaper notice. This is the only way to grapple with the maggot. It is a tedious one, we admit, but so far no better remedy has been discovered. Experienced growers say that large plants are rarely attacked, cuttings and layers appearing to suffer the most. It has also been observed that the presence of a maggot in a shoot may be detected by giving the point a gentle pull. If the maggot is within, the shoot will easily come asunder, and the hole made by the former will be seen. 
Caterpilars. - Nunerous Caterpillars infest flower garden plants, either gnawing the leaves, the shoots, or the roots. These are the larve of various species of butterflies and moths. The larve of the Large White Butterfly (Pieris brassica) feed on many plants. They are of a yellowish tint, spotted with black. The Small White Butterfly (Pieris rapre) has green larva, spotted on each side with yellow. Both are partial to annual and perennial plants. The Cabbage Moth (Mamestra brassicie) has fat, dark greyish larve marked with black and white, which feed on the leaves of dahlias, geraniums, and garden plants generally, rloing considerable harm. The

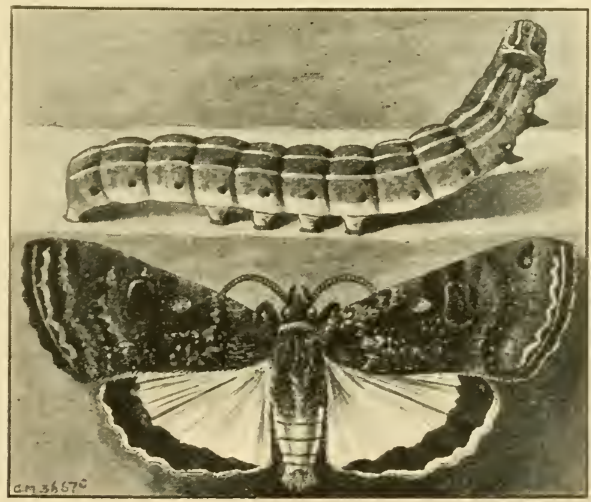

YELLOW ENDER-WING MOTH AND LARTA.

Small Ermine Moth (Hyponomeuta padellus) produce small caterpillars of a grey or brown colour, spotted with black, which live in communities protected by a web. These perts infest hawthorn and euonymus hedges and shrubs, and soon devour the foliage unless cleared. The dark hairy larve of the Tiger Moth also feed on the hollyhock, wallflower, etc. The larva of the Winter Moth, Vapourer Moth, Buff Tip Moth, Yellow Under-wing Moth, 
and many other genera, infest rose trees and devour the foliage.

Remedies-In each and every case the best remedieis are hand-picking, or syringing, or spraying with the insecticirles adrised for Aphides. In the autumn and winter, too, a careful eye should be kept upon the soil when being dug, and the pupre of these pests picked out and given to poultry. An application of Apterite, Kilogrub, or Vaporite, forked or dug in at the rate of one pound per eight
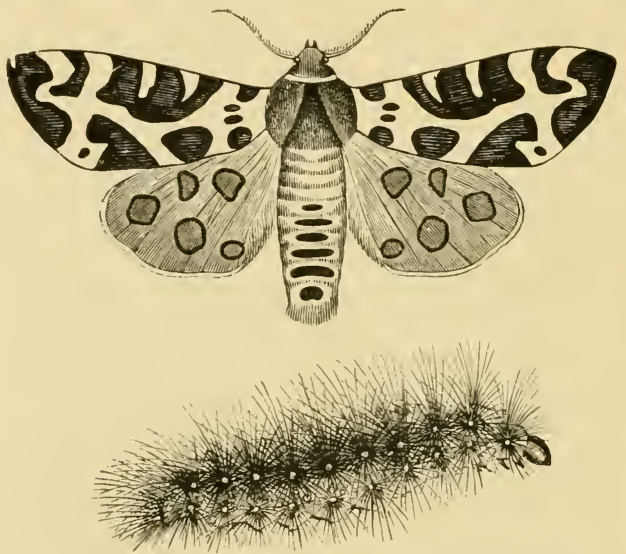

TIGER MOTH (CHELONIA CA.TA) AND LARTA.

The caterpillar is known as the "Wooliy Bear."

square yards in autumm, will to much to destroy larva or pupae in the soil.

Cuckoo Spit, or Froghopper (Philienus spumarias). - This pest is closely related to the Aphides, only larger. The perfect insects are most abundant in the autumn, and the male may be easily distinguished by its habit of leaping from plant to plant if disturber. The female lays her eggrs on the plant, and these hatch in due course into six-leggred greenish grubs, with vellow bellies. 
They at once commence to feed on the shoots, sucking the juices by neans of a powerful trunk, with which they pierce the epidermis. As the sucling proceeds they gradually exude a frothy substance through their bodies, which completely hides them from view. On removing the covering the larva will dart away to the opposite side

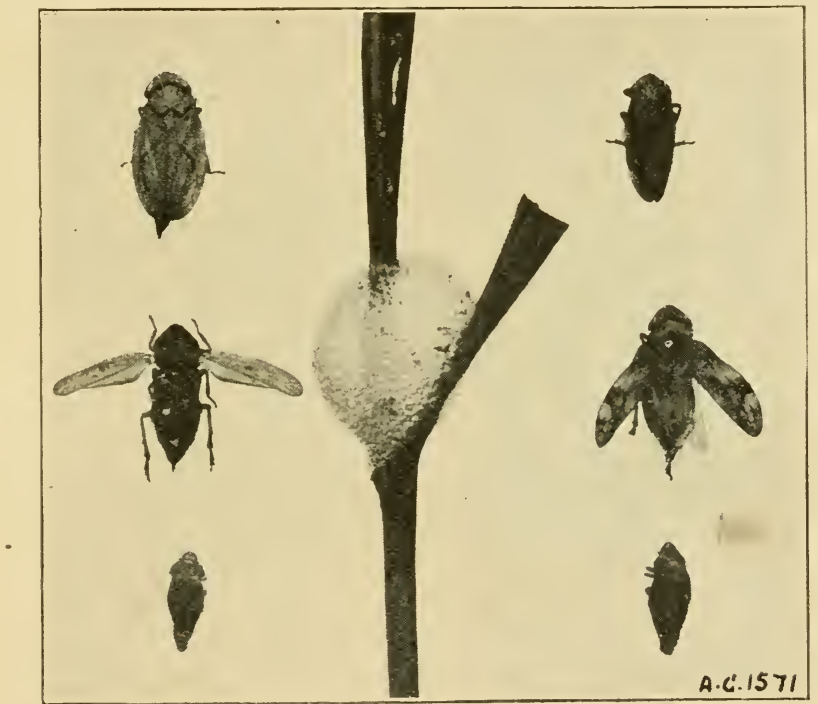

[Photo: J. G. Blakey.

FROGHOPPER OR CLCliOO SPIT FLIES AND I.ARTE.

The frothy-looking mass on the shoot conceals the larra, which suck sut the sap. On each wide the insects and larra: are shown in different stages of development.

of the shoot to escape observation, and, as soon as all is quiet again, it will start in a fresh spot, and re-cover itself with froth. If allowed to remain long on the plants the larve will cripple the shoots considerably; therefore take prompt steps for their remoral. In some seasons they are very partial to outdoor chryeanthemums, and dozens 
of frothy lumps will be seen on the shoots. Other species of Frogflies also attack the leaves of salvias and many cther plants in summer.

Remenies. - The most effective morle of erarlication is to grasp the larva between the finger and thumb, and crush it. To make sure of seizing it, blow off the froth first. If you do not care to do it with your fingers, remove the larva with an aphis brush. Syringing with one of the

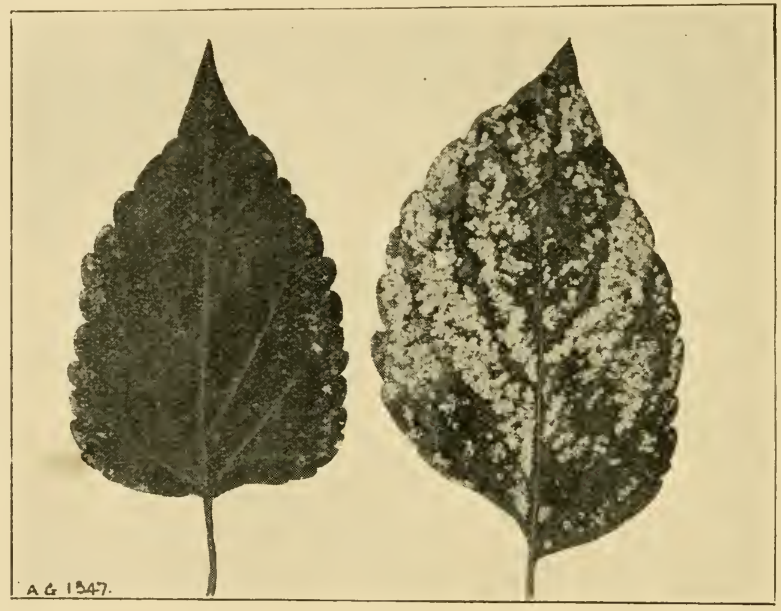

[Photo: J. G. Blakey.

SALTIA LEAF INJURED BY FlROG FLY.

The leaf on the right ehows its upper surface uninjured, while the underside shown on the left has been badly damaged.

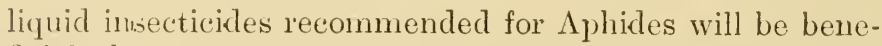
ficial also.

Earwigs (Forficula auricularis). - The Earwig has a decided partiality for feeding on the delicate petals of the blooms of chrysanthemums, dahlias, violas, pansies, and other plants, including ripe fruits, at night, and often seriously injure, if not completely spoil, them. These 
pestis are too well known to require any detailed description of their form or habits. They possess wings, which are neatly hidden from view, and hence are capable of Hying from one garden to another. On this account, the gardener has to be always on the alert to deal with fresh colonies or broods of this pest. The female hatches her eggs just like a bird, and afterwards nurses the larve till they can take care of themselves. Those who are at all

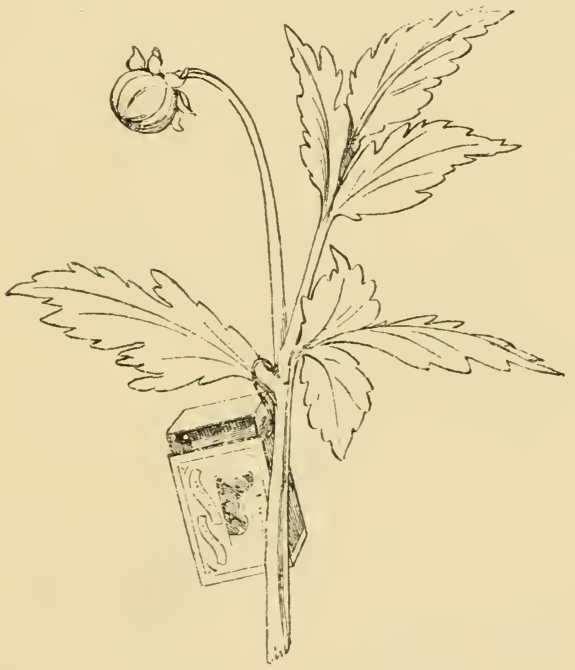

A SINGLE E.HWWIG TRAl'.

This consists of a match-box partly opened and attached to the shoot of a dahlia by means of a bit of wire.

anxious to have their blooms in perfect condition must therefore be on the look out for these pests, and adopt mearures for checkmating them.

Remenies.-Dirty flower-pots half-filled with dry moss, a sheet of paper twisted into a cone, or rolls of tissue paper placed on the tops of the stakes, will form an attractive rendezvous for them, and if these are examined 
daily, and the earwigs found therein caught and despatched, injury will be prevented.

Leaf-mining Maggots.-Chrysanthemums, echinops, hollies, marguerites, etc., often have their leaves injured by the presence of maggots just under the epidermis, the inaggots having eaten the soft tissue and leaving the bleached epidermis to indicate their presence underneath.

Remedies.- In each case crushing the maggots in the leaves, or digging them out, or pulling off and burning badly-infested leares, are the best remedies. To prevent

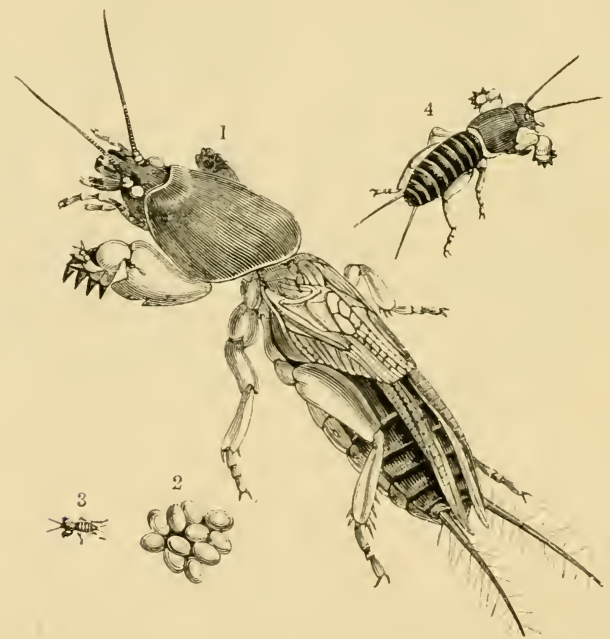

MOLE C'RICKET (GRYLLOTALPA VILG.JRI:).

Fig. 1, Fully-grown insect; 3 and 4, In different etages of growth; 2, Eggs.

the flies laying their eggs spray the foliage occasionally with the following solution: Place a piece of brick in a pail, and pour on as much paraffin oil as it will absorb, then add two gallons of water. Let the liquor stand for three days, remove all scum from the surface, and apply 
with a fine sprayer. See also the remedies for Celery Fly.

Mole Cricket (Gryllotalpa vulgaris).-Mole crickets are sometimes troublesome. They feed on the roots of border plants and grasses on the lawn. The adults are about 2in. long, have velvety-brown coloured bodies, six legs, the front ones of which are shaped like those of the mole, and a pair of hairy, rat-like tails. They burrow under the ground like a mole, hence the name of "mole cricket." The females lay from 300 to 400 eggs each, in
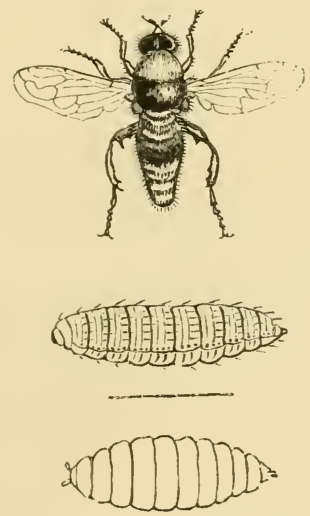

NARCISSUS FLY, LARTA, AND CHRYSALIS.

a specially-constructed nest about $6 \mathrm{in}$. below the surface. The roung are at first about the size of ants, and live in communities until they have cast their first slin; then they disperse. Mole crickets live in their burrows by day and come forth at night, when they chirp and sing. The adults fight and eat each other, and the female often devours most of her progeny.

Remedies.-Paraffin oil and soapsuds poured in their burrows will generally kill them. Digging in a soil fumigant in winter would also destroy them. 
Narcissus FIy (Merodon nareissi).-The yellowishbrown larva of this bee-like black fly feed upon the bulbs of narcissi, gnawing their way into the centres, and thus arresting growth. The Hy appears in spring, and lays its eggs on the surface of the bulbs, the larve soon hatching and commencing their destructive work. 'The result of attack is a soft, spongy, and decayed bulb.

Remedies. - Burn all soft or spongy bulbs; immerse any bulbs suspected of containing maggots in water for a week or two to drown the pests; and trap the flies in spring by placing saucers containing syrup or molasses among the plants. The appearance of this pest must be

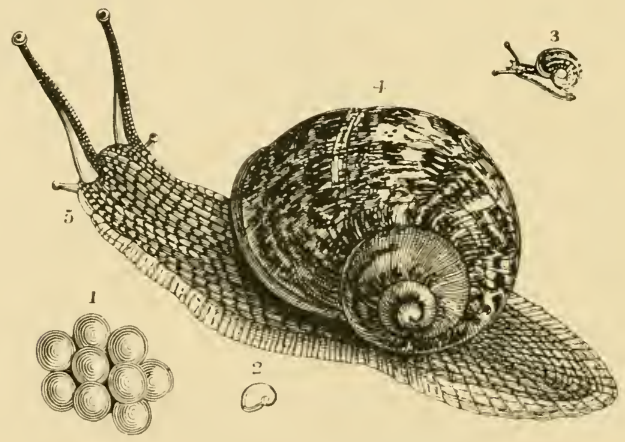

G.JRDEX SXIL (HELIX HORTEXSIS).

Fig. 1, Eggs, natural oize; Fig. 2, Newly-hatched snail; Fig. 3, Young Enail; Fig. 4, Idult snail.

notified to the Board of Agriculture. Soe Chapter I.. l'art VII.

Slugs and Snails.--Both are harmful to seedlings, young shoots, and foliage generally in the flower garden. Snails and siugs are hermajhrodites, and hence each individual is capable of producing eggs, thereby affording every facility for the perpetuation of its species on a large scale. Snails are distinguished from slugs by the possession of shells. The (iarlen Snatil (Helix hortensis) is 
fairly well known by its large marbled shell, inside of which it usually shelters by day at the base of walls or fences or among the stems of plants. They are chiefly seen in mild weather and in damp situations, being most numerous after warm showers in spring and summer. The snail lays its white globular eggs in clusters in damp soils. These soon hatch, and the baby snails proceed forthwith to levy toll upon the succulent young vegetation. In autumn snails retire within their shells, and by means of a slimy secr tion at the orifice attach themselves to walls,

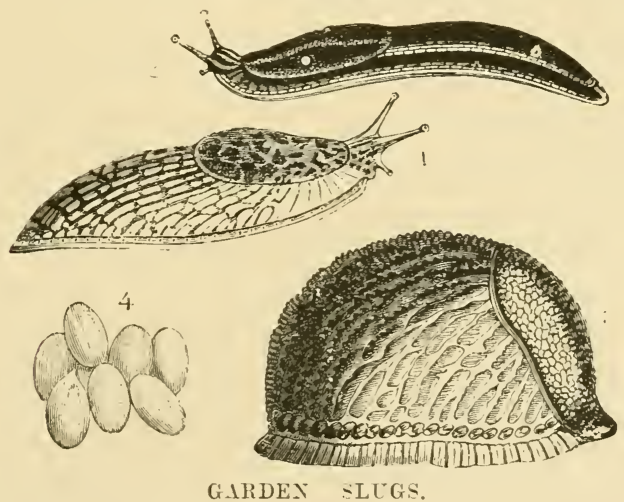

Fig. 1, Milky -lug (Limax agrestis); Fig. 2, Black Slug (Limax ater) in young stage; Fig. 3, Aduit variety of last-named species in report; Fig. 4, Eggo.

under the shelter of ivy or creepers, or against palings, where they remain dormant till spring. Snails are said to live for fourteen or fifteen rears.

Slugs differ from snails in pcrsessing no shells. There are several kinds, as the Milly Slug (Limax agrestris), whitish or ash-coloured; Black Slug (Limax ater), borly wrinkled, eolour black and pale beneath; and the Blackstriped Slug (Limax maximus), a large kind growing $4 \mathrm{in}$. to 5in. long, and with an ash-coloured borly striped with black. Ail lay their eggs in damp soil, and feed chiefly at night or on showery, warm days. They are most active 
in spring and autumn; in winter they hide in the crevices of the soil.

Remenies.-Thrushes and blackbirds feed largely on snails. Dressing the soil in autumn with soil fumigants like Kilogrub and Vaporite will destroy their eggs. So also will a dressing of quick or ground lime in February. Two tablespoonfuls of liquid ammonia added to a gallon of water, and applied to infester areas in the evening, will kill both slugs and snails, and do no harm to the plants. Pieces of orange-peel laid about the borders will attract slugis and snails, and enable them to be easily caught. Dustings of soot or lime, if repeated every evening for a week, will also help to get rid of the pests.

White worms (Enchytracids).-According to the Rev. Hilderic Friend, a gentleman who has made a life sturly of worms, the small white worms so plentiful in decayed manure and in soil, and of whose habits or life history comparatively little has been known, are pests capable of inflicting serious injury upon the roots of plants. These vary in size from tiny microscopic creatures to an inch in length. He says that there are upwards of fifty native species discovered so far. There is no doubt that gardeners have in the past overlooked the fact of white worms being injurious to crops, and other pests have been credited with any injury done thereto.

Remenies. - In the case of leaf-mould or old manure containing white worms it would be well to mix some Vaporite with both before using in the garden. For potting purposes the material should either be heated to kill the worms and their ova, or spread out and sprinkled with boiling water before mixing with the compost.

Worms, or Earthworms. - The idea prevails that the earthworm eats seeds and the roots of plants, and it is often held responsible for causing the turf of the lawn to go yellow and die. The worm is a good friend rather than an enemy to gardens. So far from doing harm to 
gardens and crops, it really does an immense amount of good. Its good qualities consist, first of all, in draining the soil, and, secondly, in helping to materially increase its fertility. Thus, in the first case, its indefatigable method of tunnelling the soil provides channels through which the air and moisture can pass downwards from the surface. The air which passes downwards acts beneficially upon the stored-up elements in the soil, oxidising and liberating substances for the sustenance of plant growth, which would otherwise be unavailable. The rains, moreover, which are enabled to pass through the tunnels are charged with nitric acid, which, on coming in contact with

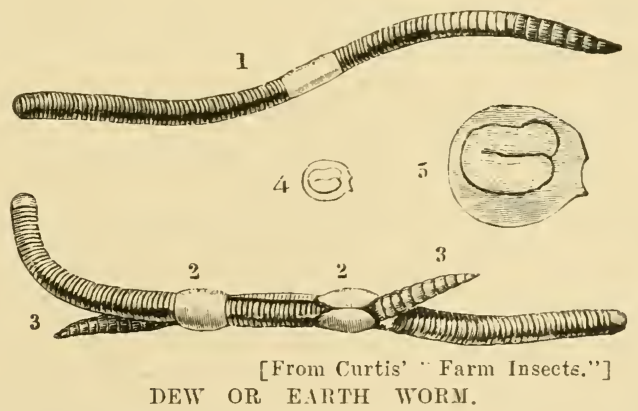

1, Earthworm (Lumbricus terrestris); 2, Rings; 3, Head of the worm; 4 and 5 , Eiggs of the worm.

the soil, becomes converted into nitrogen, another valuable plant foor. Furthermore, the air and moisture help to provide congenial conditions for the development and activity of thase wonderful and minute organisms, the nitrifying bacteria. Without air the latter could not exist, and without their presence in the soil plants could not thrive. Nor is this all. By tunnelling and draining the surface, water which would otherwise remain stagnant, seal up the capillary tubes, and keep the temperature low, is allowed to pass into the subsoil, learing the surface drier and warmer. Then, worms enrich the soil by ejecting 
to the surface excrement consisting of desicated regetable matter and soil. The excrement is popularly known as "worm-casts," and, being compcised largely of vegetable matter, they are rich in plant food. Professor Darwin, in his most interesting work, "Vegetable Mould and Earthworms," says, as a result of his experiments and researches on the subject, that each large worm ejects about 20oz. of excrement, or castings, per annum. He further states that each acre of pasture land contains on an average about 26,886 worms, the castings from which amount to 15 tons ammually. In ten years, at this rate of deposit, a layer of an inch of mould would be added to the original surface. Worms are more numerous in garden soils than in pastures. Darwin records a statement made by another scientist, that there are 53,767 worms to the acre.

The Dew or Earth Worm (Lumbricus terrestris) has a body consisting of 100 to 200 cylindrical rings, or segments, each furnished with minute bristles. It is destitute of eyes, breathes through its skin, has no jaws or teeth, but powerful muscles in its mouth, by means of which it triturates its food. Worms are sensitive to light, and hence come to the surface mainly at night. They gradually draw in fallen leaves or decayed regetable matter into their burrows, then coat them with a special fluid, and afterwards gradually devour them, together with particles of soil, sand, ete. If an midetached leaf have its point fixed in the soil, and the worm come in contact with it, it will begin to suck off all the soft parts, leaving the veins or ribs intact. Darwin says worms are cannibals, and will eat any of their comrades that have been severed. The earthworn is a hermaphrodite, and is reproduced from an egg. When first hatched the baby worm is an inch long, and when full grown attains a length of upwards of a foot. In colour it is rosy, white, or bluish, aceording to the soil or position it is in. The head is pointed and the tail flattish. The large rings contain the organs of generation. 
lienevies.-(1) On lawns the " casts" thrown up enrich the surface soil and provide extra food for the grasises. It is true the "castis" are objectionable, but this difficulty is easily overcome by sweeping the surface once or twice a week with a birch broom, and afterwards rolling it. The " casts" are then distributed, and pressed down to the roots of the grass, and the annoyance, if any, got rid of. (2) If very numerous and objectionable they may be got rid of in a wholesale manner by watering the lawn with a solution of corrosive sublimate (bichloride of mercury). Dissolve an ounce in hot water, and add water to make 40 gallons. Apply in wet weather; then the worms will come to the surface, and may be swept off. Do not give the poisoned worms to poultry, but bury them. (3) To prevent worms coming to the surface of lawns, when making new ones spread a layer of fine cinder ashes one inch thick on the soil, then add an inch of fine soil and lay the turf on this. (4) Then, if worms are troublesome on gravel paths, it is because the surface is not kept well rolled. If the surface be well rolled and made firm worms will go Elsewhere, and the difficulty will cease. The only slight harm worms do in borders is to make the soil too loose round the plants. If the latter have the soil around them pressed down occasionally no harm accrues. (5) Another remedy for eradicating worms from lawns: Mercuric perchloride, 10lb.; hydrochloric acid, 4lb. ; water, 6lb. Use half an ounce of this mixture to every three gallons of water. The mercury is a langerous poison, so should not be left about. Sweep off the worms and bury them.

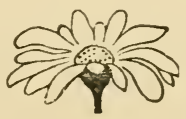




\section{CHAPTER II.}

\section{DISEASES OF HARDY PLANTS.}

Bulb Diseases.-Bulbs are subject to the attack of several fungoid diseases. Thus, hyacinths are occasionally infected with Sclerotinia, a fungus forming patches of olive-brown mould, preceded by yellowish patches on the leaves. The mould eventually descends to the bulb and causes it to decay. Another disease of bacterial origin, called Bacteriosis, causes yellow patches to form on leaves and bulbs, and checks the growth of the bulb. A black mould, called Smut, forms on the foliage of colchicums and muscaris, and finally destroys the bulbs. Tulips are attacked similarly to hyacinths, and a form of mildew attacks the leaves of the snowdrop.

Remeny.-The only one is to destroy all infected bulbs by burning.

Carnation Diseases. - The carnation is subject to the attack of at least three fungoid pests. First of all, there is the Pink Tiust (Puccinia arenaric), which forms small black spots in circles on the leaves and stems; the Fairy Ring Fungus (Heterosporium echimulatum), which also forms black clusters in irregular circles on the surface of the leaves, like the miniature fariry rings of the pasture; and Macrosporium nobile, which manifests itself in the form of small dark-coloured spots on all sides of the leaves and stems. All three are destructive to the plants, killing them in due course.

liemedes.-Badly-diseased plants should be burnt. Those only slightly attaclied should be sprayed with a Sulphide of Potassium Solution (Formula No. 23). If the 
plants are frequently sprayed these fungi will have no chance to develop. The foliage, too, should be liept fairly dry, then the spores cumnot vegetate.

Hollyhock Rust (Puccinia malvacearum).-.- At one time this fungoid discase played great havoc with the hollyhock. Unfortumately, it is still with us, and many

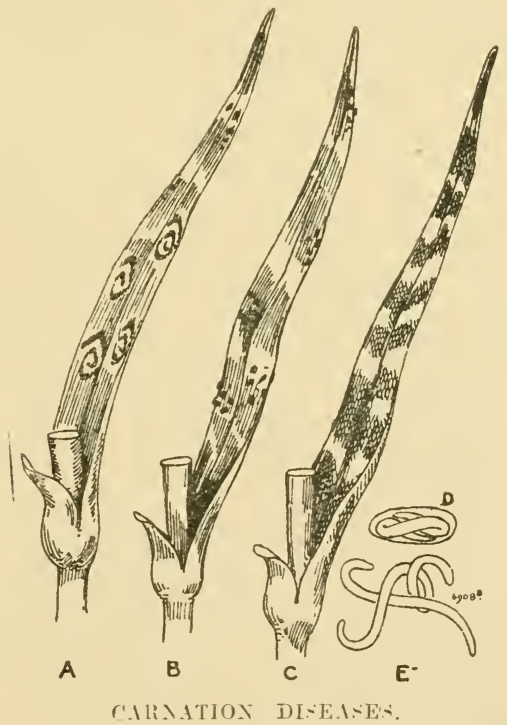

1, Carnation liust; B, Carnation spot; C, Eelworm biseace; E, Kelworm largely magnified.

lovers of the hollyhock consequently find it difficult to grow plants free from it. Its presence is easily detected by a multitude of brown warts or pustules studing the under surface of the leaves, as well as the surface of the stem. The fungus causes the leaves to turn yellow and die, and the growth consequently becomes stunted.

Remenies.-Diseased leaves should be pulled off and burnt at once. Wholly diseased plants should be treated 
in the same way. No seeds or cuttings should be taken from plants infected with the fungus. As a preventive remedy spray the plants occasionally in spring and summer with Bordeaux Mixture (Formulie Nos. 20 or 21 ).

Japanese Lily Disease.-It often liaplens that imported bulbs of Lilium auratum and speciosum fail to grow satisfactorily after planting or potting, the bulbs and shoots turning rotten. The disease is undoubtedly present in the bulbs before they are imported here. It is due to a fungus called lihizopus necans.

Remedras.-Examine newly-imported bulbs and remove all decayed or discoloured scales and burn them; then immerse the bullos in a 1 per cent. solution of salycilic acid for twenty minutes before planting. Diseased bulbs should at once be burnt.

Madonna Lily Disease. - Of late yearis this beatuiful lily has been badly attacked by a fungoid disease (Botrytis elliptica). It first appear's in the form of orange-brown or buff specks, then destroys the leaf tissues and causes the foliage and stems to turn black. It appears to be a difficult disease to cope with.

Remedies. - In the case of badly-diseased plants the best remedy is to at once up-root and burn both stems and bulbs to destroy the spores of the fungus. In the case of those only slightly attacked, lift the bulbs in July, place them in a paper bag containing flowers of sulphur, and rive the whole a good shaking to work the sulphur well into the scales of the bulbs. Afterwards replant in a fresh site. Spraying with the Sulphicle of T'otassium remedy (Formula No. 23) in spring and summer might prevent the disease developing. Immersing the bulbs, as advised for the Japancs I ily 1)isease, might also be tried.

Proony Diseases.-A few diseases attack the paeony, but the only ones wortly of special mention are the Drooping Paeony Disease (Botrytis paroniar), which appears on the leaves in the form of a white mould just 
before the flowering period, and causes the stems to droop and the leaves to shrivel and die. Another disease, called the Prony Rust (Cronartium preonia) attacks the under siles of the leaves in the form of bright yellow or rusty pustules.

liemony. - The only one is to promptly cut off and burn all diseased leaves and stems to destroy the fungus.

Sweet Pea Blight (Peronospora trifoliorum). - A fungoid disease frequently met with on plants of the pea family (Leguminosie). It first appears in the form of vellowish blotches on the leaves, these eventually becoming covered with a dense grey mould, the fruiting stage of the fungus. The disease gradually spreadis to the shoots and seed pods, and the rcsult is crippled growth and the erentual death of the plant.

Remedies.-In the ease of badly-infected plants, pull them up and burn them, and especially burn all dead haulm in the autumn, as the winter spores hibernate in these, and are liable to give birth to the summer form of the fungus the next season. Spraying with a solution of soft soap and sulphide of potassium is a good preventive remedy. Dissolve $3 \mathrm{oz}$ of soft soap and $1 \mathrm{oz}$. of the potassium in inot water, and add water to make two gallons.

Sweet Pea Mildew (Erysiphe polygoni). - Another fungoid disease attacking the leaves, stems, and seed-porks in dry seasons. The white mealy mould, indicating its presence on the plants, is the fruiting stage of the fungus, the myceilum, or plant form which produces the fruit (spores), having previously established itself in the tissues of its host, and thereby injured the cells. The winter or resting spores consist of minute black spots, which in the following spring produce the mycelium that injures the plant.

Remedies.-Dust the plants occasionally with a mixture of four parts of flowers of sulphur to one of quicklime from the time the plants are $1 \mathrm{ft}$. to $3 \mathrm{ft}$. high, and burn all badly-diseased plants, also old haulm, in autumn. 


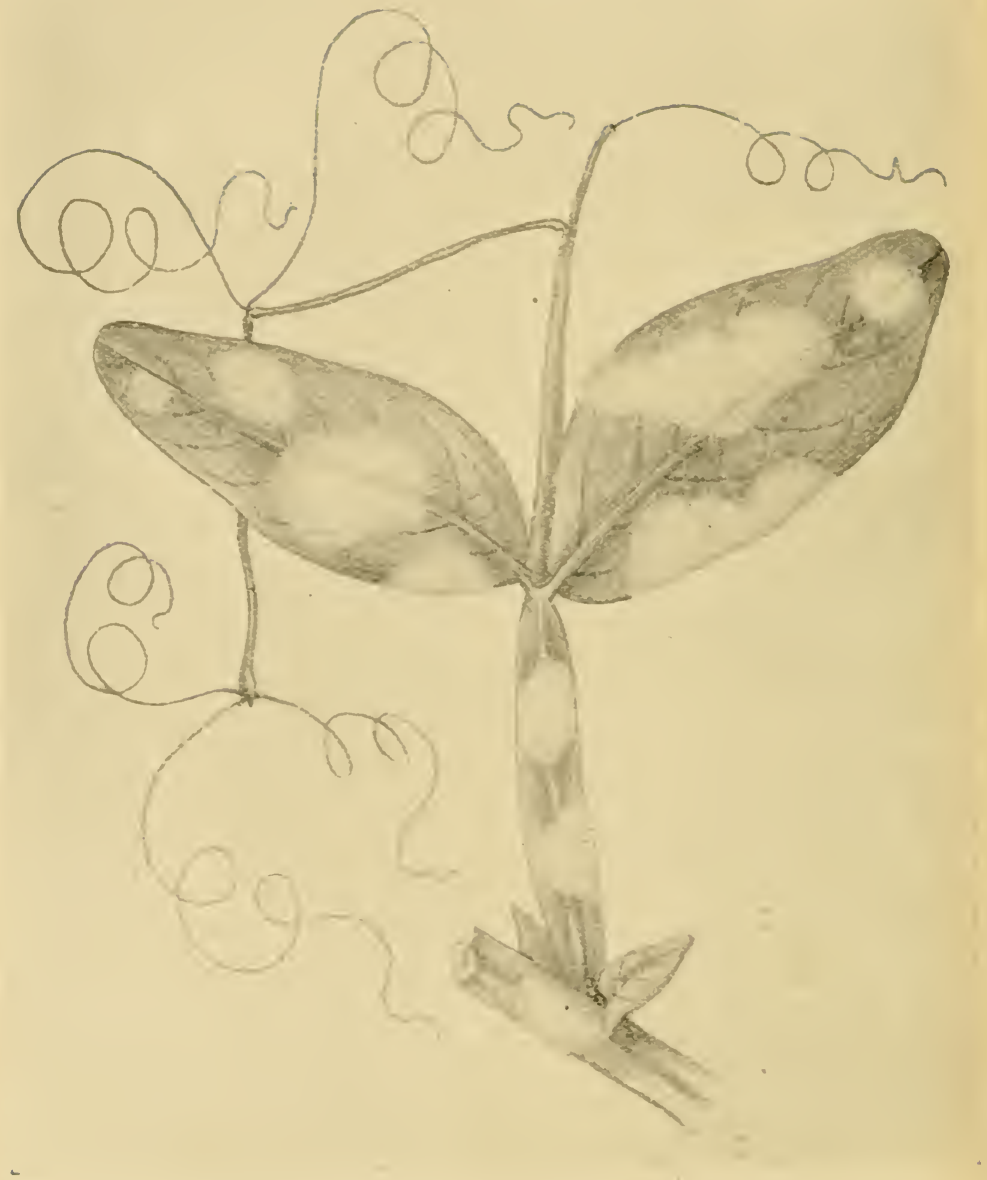

SWEET PEA BLIGHT (PLRONO-PORA TRIFOLIOREM).

The white batches are caused hy the fungus. 
Sweet Pea spot (Ascochyta pisi).-This fungus attacks the pods first in the form of pale green spots, changing later to white bordered with black. The spots are more or less depressed, and the pods become distorted in shape.

Remedies. - Burn all badly-rliseased pods, and, as a prerentive, spray the plants from the time they are a few

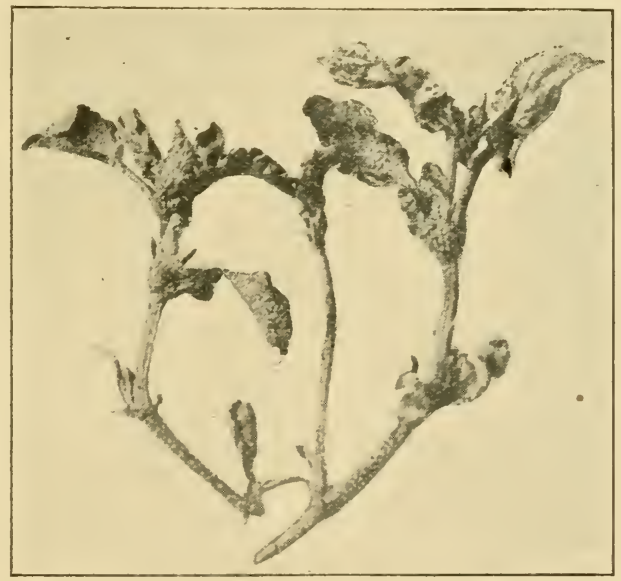

[Photo: H. A. Smith.

VIOLET REST (PLCCINIA VIOL.E).

1 fungus which derelope on the leares and shoote in the form of pustules of a rusty brown hue.

inches high with the soap and potassium solution advised for Sweet Pea Blight.

Sweet Pea Streak. I mysterious disease which attackis the leaves and stems in the form of bright green or brown streaks. Mr. George Massee, F.L.S., the eminent mycological expert, is of opinion that the disease is of a physiological nature, and due to the use of nitrogenous manures in excessive quantitien.

Rejebies, - Attacked plants should be burnt, since there 
is no known remedy. It is advisable also not to grow peas in the same position in consecutive years.

Violet Diseases.-Quite a number of diseases attack the violet and pansy. Thus, the Violet Leaf Spot (Phyllosticta violie) causes whitish spots to form on the leaves, which cripple the growth. The Violet Smut (Urocystis violie) attacks the violet, causing the petioles to become swollen and gouty, and the leaves to be blistered and distorted. The Violet Rust (Puccinia violie) appears on the leaves in the form of rusty-brown or blackish pustules, and cripples the growth of the leaves and stems. Then there is also the Violet White Mould (Ramularia lactea), which attacks the leaves in the form of a white mealy mould; and the Violet Black Mould (Cereospora violee), which forms dark spots on the foliage.

Reuedies. - It is advisable in nearly every case to pull up and burn infected plants, as once they are attackerl by the disease their growth is generally so crippled that fungicides are of little avail. Probably spraying with a fungicide might prove a preventive, if not a cure.

\section{CHAPTER III.}

\section{ROSE PESTS.}

\section{A.-INSECTS.}

Ants.-These, though they do not directly injure plants generally, yet in an indirect way often prove injurious. Ants, as is well known, take great care of Aphides, and may often be seen carrying the young ones to pastures new, so that they are leagued with the gardeners' and with the rosarians' greatest enemy. A sticky, sweet liquid, called honeydew, secreted by the Aphides, con- 
stitutes an attraction for ants, who feed upon it. Cases have also been observed where rose blooms have, as it were, been saturated with this honeydew, and eaten entirely by ants.

Remedres.-The remedy is obvious; if there are no

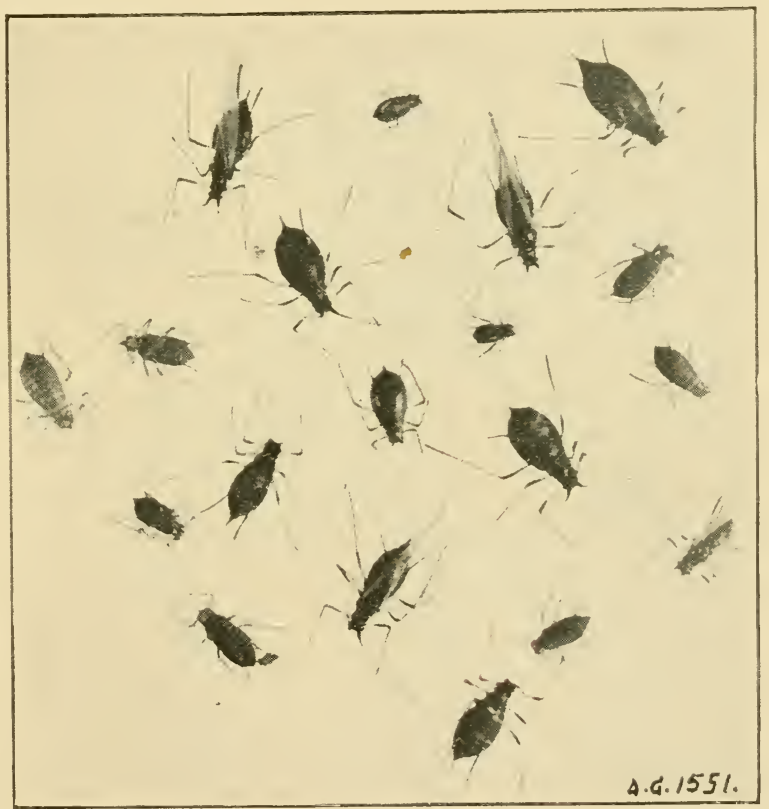

ROSE APHIS OR GREENELY.

[Photo: J. G. Blakey.

These are slightly magnified, and show both winged and winglees females in different stages of development.

Aphides there will be no ants. Vigorous syringing with water or quassia solution will disturb the ants, and cause them to go elsewhere; while, if their nest or runs can be traced, paraffiu may be poured over them. Sce also re. marks on p. 210. 
Aphides, or Greenfly.-Three species of Aphidesnamely, Siphonophora dirhoda, rosie, and rosarum-infest the shoots and leares of the rose. They are all popularly known as "Greenfly." There are winged and wingless females and similar males. The first brood of the

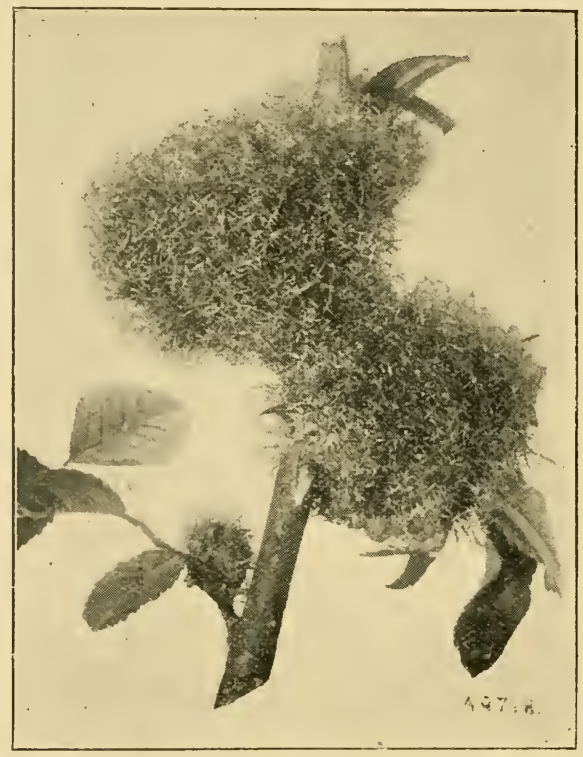

[Photo: H, A. smith.

\section{G.ILLS ON I ROSE SHOOT.}

The galls are mess-like and reddich in colour. Common on wild roees.

year is produced in spring from eggs laid on the shoots the previous autumn. From this brood are produced viviparous females, which bring forth their young alive. Each succeding generation do the same until autumn, when the last generation consists of oviparous females that lay eggs. It appears that the presence of the male insect is not necessary until the last generation of the season. 
Aphicles are possessed of wonderful fecundity; hence their presence in such immense numbers on our rose bushes. They not only suck out the sap from the cells and cripple the growth-of the shoots, but also secrete a substance called honeydew from cornicles, or pores, on their bodies, which forms a gummy surface on the leaf and seals up the breathing pores, or stomato, thus preventing healthy growth taking place.

Remenies. - It is evirlent that Aphides should not be tolerated on rose trees if we want the latter to grow and flower freely. Spray, therefore, directly Aphides are detected, with Formula No. 16 or with one of the advertised insectisides. Always do the spraying in the evening.

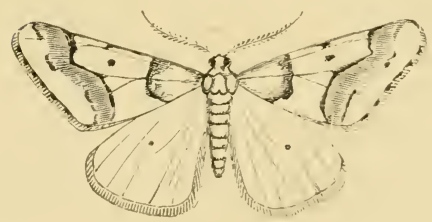

A.

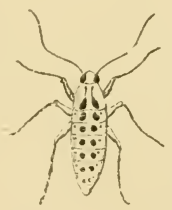

B.

MOTTLED CMBER MOTH (HTBERNIA DEFOLIARIA). A, Tringed male; B. Wingless female.

Bedeguar Gall Fly (Cynips rosie).-Most people have observed what appear to be small bunches of mosis enclosing rose shoots on wild and sometimes garden roses. These are galli; and known as the Bedeguar Gall, or Rose Bedegurr. In summer they are green, but change on the approach of autumn to red. They contain grubs or maggots, which change to pupre in the gall, and emerge as small flies the following spring. The galls are produced by the irritation and stoppage to the flow of sap owing to the insertion of eggs in the bark of young shoots by the fly, but why the growth should take the peculiar and pretty form it does is not exactly known.

Remedis.-Their presence is objectionable on garden 
roses, as the shoots are unable to grow properly. The latter should be cut off before the fly emerges.

Caterpillars. - The larve of a number of moths, most of which have been described elsewhere in this rolume, infest the rose, and often do consirlerable injury to the foliage, etc. The chief culprits are the Vapourer Moth (Orgyia antiqua), Pale Tussock Moth (D)asychira pudibunda), Gold-tail Moth (Porthesia similis), Browntail Moth (Euproctus chrysorrhcea), Buff-tip Moth (Pygaera bucephala), Dagger Moth (Acronycta psi), Winter Moth (cheimatobia brumata), Mottled Umber Moth (Hybemia defoliaria), Rexl Rose Maggot (Pardiae tripunctata), Brown liose Grub (Spilonata roborana), Green Rose Maggot (Tortrix ribeana), Yellow Rose Grub (Crosia holmiana), and the Rose-leaf Miner (Nepticula anomalella). The Red Rose Maggots spin the leaves together and feed upon them and the buds. The Brown Rose and the Green Rose Maggot do the same thing. The Leaf Miner forms tunnels in the leaves, and the rest feer on the foliage generally.

Remedies.-During the spring and summer the rosarian must be constantly on the alert looking out for caterpillars, and remove them by hand. In the case of those caterpillars that roll the leaflets together, it is almost impossible to reach them by means of insecticides; handpicking is therefore the only remedy. A vigorous shaking of the bushes will cause many of the caterpillars to fall to the ground, but, unless a sheet or sack be placed underneath to catch them, they will crawl up the stems again and do further mischief. Spraying with Formulac Nos. 10) or 11 will destroy all the foregoing larve.

Chafer Beetles.--Three beetles, in addition to the liose Beetle just described, also attack roses. The Common Cockchafer Beetle (Melolontha vulgaris), also known as the May Bug, feeds on the leaves and petals, and their large, fat, white grubs frequently eat the roots of tender 
roses. The Summer Chafer (Rhizotrogus solstitialis), a somewhat similar, but smaller kind to the last, also feeds on the foliage and blooms. These beetles feed in the evening, as a rule. Then there is the Garden Chafer (Phyllopertha horticola), a reddish-brown and greenish beetle, which commonly infests rose bushes during the summer. It fecds by day.

Remedies. - Search for the bectles on dull days or in the evening. There is no other way of dealing with them. Any fat grubs found in the soil should be promptly destroyed.
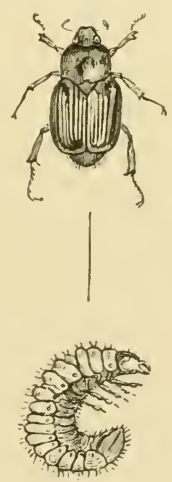

THE JUNE BUG (PHYLLOPERTHA HORTICOLA).

Leaf-cutting Bee (Megachile centuncularis). - T'his bee produces a similar spoliation of the foliage to the Antler Sawfly. It very carefully nips out of the edges of the leaves circular pieces, with which it builds its nest. It does its work neater and with more exactness than the s'awfly, and makes no perforations.

Remenies. - The best remedy is to catch the bee with a butterfly-net; it possesses a sting. Or, trace the bee to its nest and pour paraffin in the hole.

Leaf Hoppers. - The Frog Hopper, or Cuckoo Spit (Philænus spumarius) produces yellowish, active larvæ, 
which siccere themselves in a frothy substance on the base of tiower-buds, and suck out the sap. Another insect, the Rose-leaf Hopper (Typhlocyba rosa), congregrates on the leares in summer, lays its eggs beneath the slin, and from these are hatched small pale yellow larve, which wat their way out of the leaf and then feed on the under surface, causing it to become mottled or marbled.

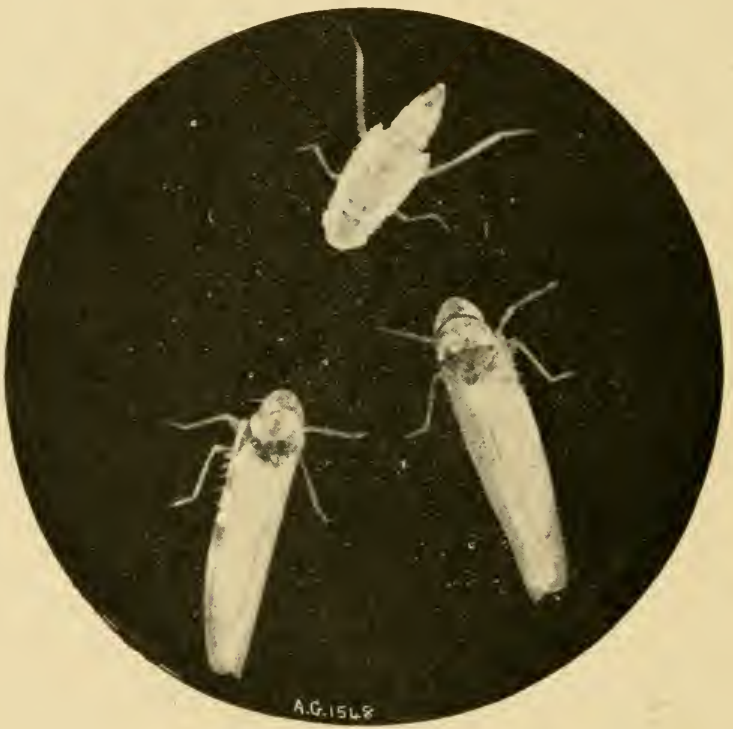

[Photo: J. G. Blakey.

FROG FLIES WHIOH OCCASIONALLT INJURE ROSE LEATES.

The ulper figure is the larra, and the two lower ones the perfect flies.

Renevies.-Hand-pick the Frog-hopper larvar, or spray with Formula No. 13. In the case of the Rose-leaf Hopper, also spray with the same formula.

Rose Beetle (Cetonia aurata).-This is a handsome beetle, being bright green shaded with rich gold, and 
about three-quarters of an inch in length. It may often be seen flying round and over rose blooms during summer, or else engaged in tearing the petals in its effort to get at the stamens and pollen. White and light-coloured rosen are greater favourites with it than dark ones.

REMedr.-Hand-picking of the beetles is the only effectual remedy. The larvie do no damage, as they feed only on decaying regetable matter.

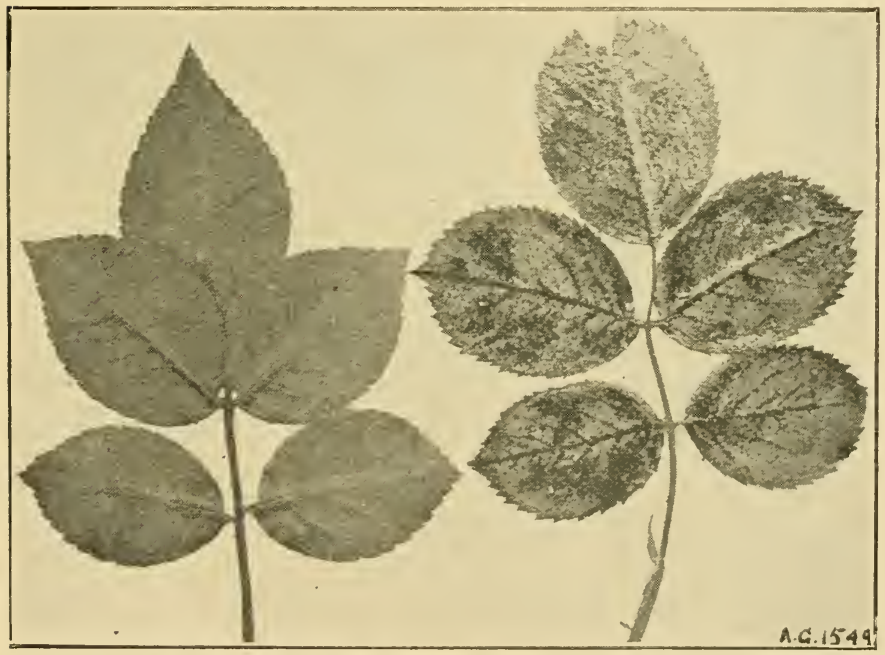

ROSE LEATES: ONE HEALTHY AND ONE INJURED BY FROG FLIES.

Sawflies. - The larre of these insects are exceedingly destructive to rose trees. Some feed on the leaves, others on the pith of the young shoots. The leaf-feeders are Eriocampa rosæ, Blennocampa pusilla, and Emphytus cinctus. The chief pith-feeding perst is Precilosoma candidatum. The Eriocampa larve are slug-like in form, humped in front, with yellowish-green bodies, and an orange-coloured head. Those of the Blennocampa are short, stumpy, with green bodies, pale brown heards, and 
short hairs on their baclis. The Emphytus larve have stout, tapering borlies, dark green on top, light grey sides, white legs, and yellow or brown heads. They feed on the leaves till fully grown, then bore into the shoots and become pupae. Lastly, there are the larve of Poecilosoma, which bore into the young shoots of rose trees, and cause them to wither and die. They are of a dull white or yellowish colour.

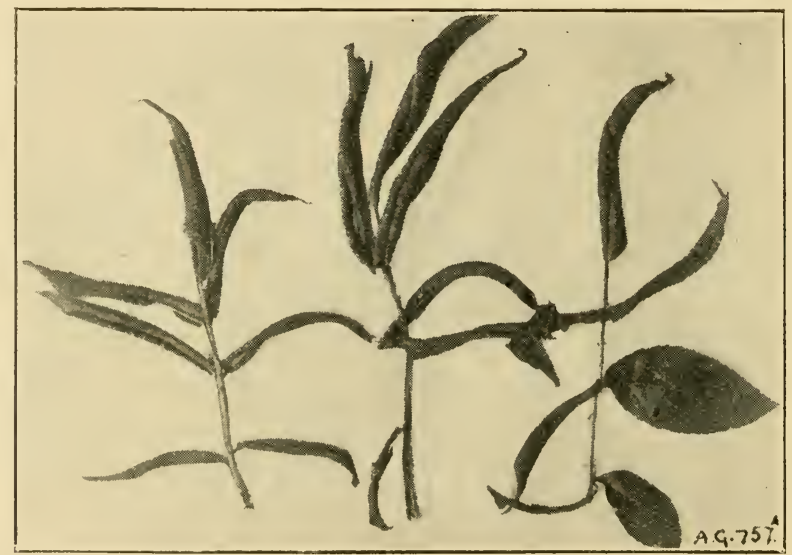

[l'hoto: H, I, imitls.

ROSE LEALES INFESTED WITH LE.IF-ROLLING SAWFI.Y.

The larve of Blenocampa pusilla roll the leaves into a tubc, as shown in illustration, and then feed oin them.

Riemenes.--All the leaf-feeding larva may be destroyed by sprinkling the foliage with sulphur or hellebore powder, or syringing with one of the standard insecticides now on the market. Where only a few of the larvie are to be seen, hand-picking is the best plan to adopt. In the case of the pith-boring kinds, cutting off and burning any shoots that show signs of withering sudilenly will make sure of getting rid of these pests. 
Scale Insects. - The hose Scale (Diaspis rosie) and the Brown Scale (Lecanium persica) infest the shoots and leaves of roses, especially those grown under glass. The first-named attacks wild roses, and may also be frequently found on garden roses. The Brown Scale lays its eggs about the middle of May, and the larva appear in June. The latter are of a vellow or pale-red tint, and furnisher with fine filaments at both ends. During the summer they wander about the shoots, piercing the epidermis and sucking out the sap. The following spring they moult

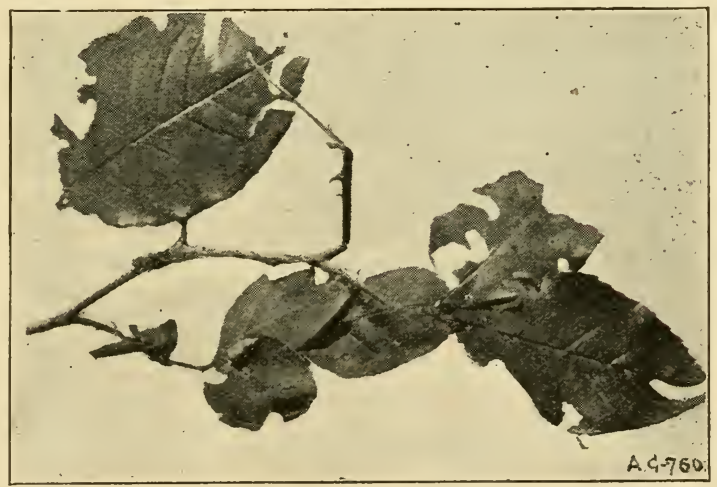

[Photo: H. A. Smith.

ROS: LEAVES EATEX BY WEEVILS.

One of the weevils may be eeen on a leaf busy feeding.

and soon attain maturity, their presence being indicater by their reddish-brown oval or hemispherical bodies attached firmly to the bark. The Rose Scale females lay their eggs in August. In due course orange larva are produced, and these settle themselves down to sucking out the sap. Eventually they clothe themselves with a deep red scale, and when they reach maturity lay eggs, and finally die.

Remedies.-Spray with a Soft Soap and Quassia Solution (Formula No. 1.t) in May and June for the Brown 
Scale, and in August for the liose Scale. In cases of a bad attack spray also in winter with a solution of Gishurst Compound.

Weevils.-The Raspberry Weevil (Otiorhynchus picipes) and the Rerl-legged Weevil (Otiorhynchus tenebricosus) attack the foliage of roses by night. They are also not particular about eating the flower-buds and young shoots. During the day they hide in crevices of the soil, ascending the stems at night. They are not very large, and of a brownish or black colour, and when disturbed fall to the ground and feign death.

Remedies.-Lay pieces of sacking on the ground under the bushes; lift these at daylight, and the weevils will be found hiding beneath. Dig in Vaporite or Kilogrub around the bushes to destroy the ora and larvie in the soil.

Other Pests. - Thrips and Red Spider also infest roses grown under glass, the remedies for which will be found in the section devoted to greenhouse plants.

\section{B. DISEASES.}

Anthracnose (Gloeosporium rosie, Hals.).-When a rose is barly infested with this fungus the leaves are small and pale, and the shoots die at the tips. Sometimes the stems may be dead for a foot or more from the extremity. Not infrequently one branch will be dear? clear to the base, and sometimes two or more are thus destroyed. The dead twigs show pimples quite evenly distributed over the surface, and from some a minute, often curved, horn of a reddish colour protrudes. When such stems are placed in a moist chamber the whole decaying surface becomes closely covered with numerous, almost brickred, masses of spores, and the disease spreads rapidly through the adjoining parts of the twigs that seemed healthy when placed in the moist chamber. The rapidity with which the fungus would spread was a subject of sur- 
prise. In four days from the time spores were introduced into sterilised sections of rose twigs in test tubes, the whole of the culture would be covered with the spore masses.

Pinuedies.--Burning the infected bush is the only way of stamping out this disease.

Canker.-This is a disease which of late years has proved exceedingly troublesome to growers of the Maréchal Niel rose. The lower part of the stem should frequently be examined, and as soon as shrinkage or swelling is observed, cut a little of the bark away to see if it is decaying. The earliest form of canker is a shrinkage in the bark, caused by some unknown disease, which keeps spreading until it gets all around the stem, then the part above it dies. But before this takes place, a swelling of a warty appearance forms just above it; this is caused by the descending sap being stopped in its downward course; it seems to be trying to make a growth to cover the wound, but, of course, cannot do so.

Remedies. - All this knotty excrescence, also the shrinkage, should be cut away, likewise all decayed wood and bark; sometimes there will be dark narrow streaks running some distance beyond, these must be followed up until every portion is cut away. Then dress the wound with either Bordeaux mixture, sulphate of iron, two ounces dissolved in a gallon of water; or sulphide of potassium one ounce to twelve gallons of water. If none of these are at hand, rub the part well with flowers of sulphur. After (whichever is used) make a poultice of equal parts clay and cow manure and bind round the wound. The summer is the best time for the operation, as the wound heals over much more quickly then.

Downy Mildew (Peronospora sparsa, Berk.).--Some rose growers are troubled with a second form of mildew which differs in many ways from ordinary mildew. It is less easy to detect, and, being more deeply seated, may do 
greater damage before detected than the powdery mildew. It is likewise less easy to eradicate, because it thrives within the substance, while the sphierotheca feeds superficially. This fungus causes the leaves to fall off sud-

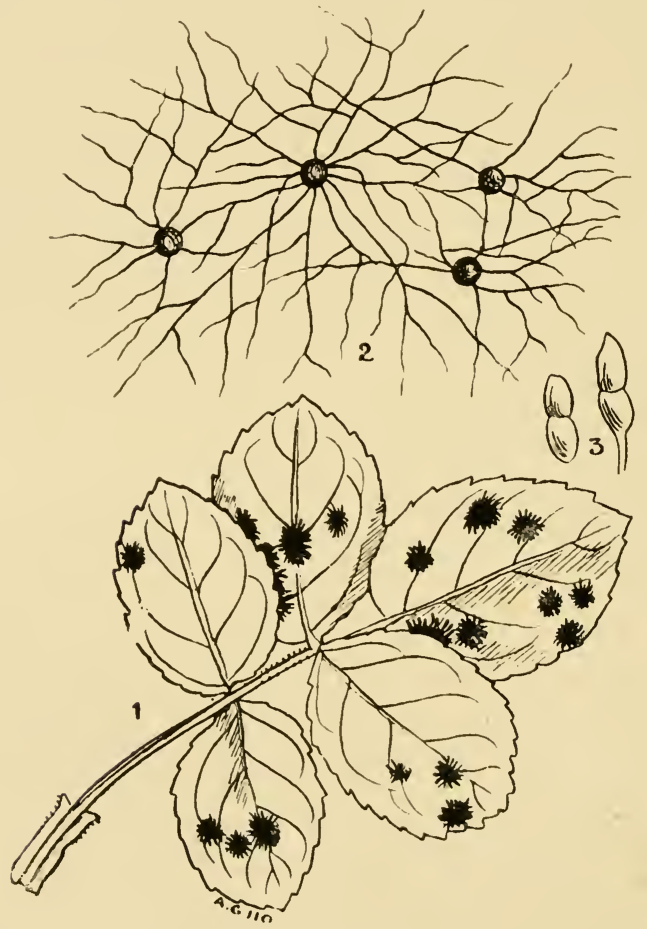

BLACK LEAF-SPOT.

1, Roeo leai infested with the fungue, natural size: 2, Theads creeping over the black spots, and bearing the fruit, multiplied by $80 ; 3$, cporee of the fungus contained in the fruit borne on the white threads multiplied by $4 \mathrm{CO}$.

denly, and the young shoots to turn black and die. It attacks roses grown under glass, and in the case of a bad attack often seriously cripples the growth. 
Remedes. - First thoroughly spray with Formula No. 25, and then apply flowers of sulphur freely by means of a sulphurator. All diseased shoots should be cut off and burnt.

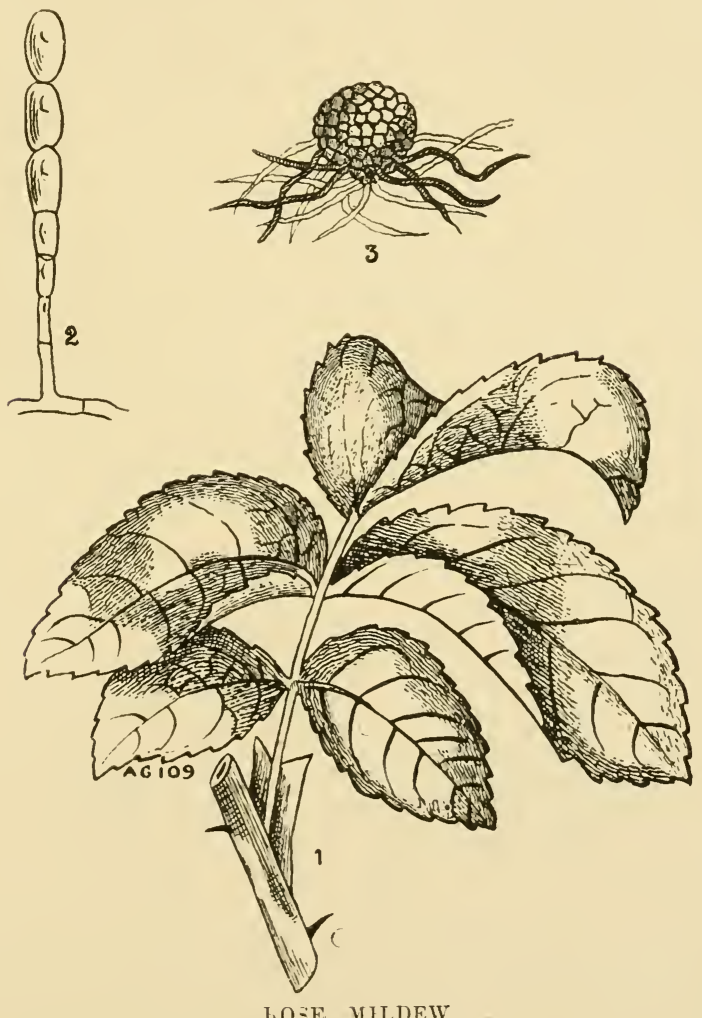

1, Portion of stem and leaf attacked by mildew, natural size; 2, Chain of spores of summer fruit. multiplied by $400 ; 3$, Winter form of fruit containing epores which germinate the spring following their production, multiplied by $4 C U$.

Mildew (Spharotheca pannosa).-One of the oldest troubles of the rose grower is the mildew. This derelops 
very suddenly on the foliage in the greenhouse or outside it, giving the leaves a powdery appearance, and causing them to become more or less misshapen. In a mild form the foliage may be only mealy, but frequently the surfaces become uneven and the whole leaf twisted. If left unleeded the enemy will ruin the plants attacked, and

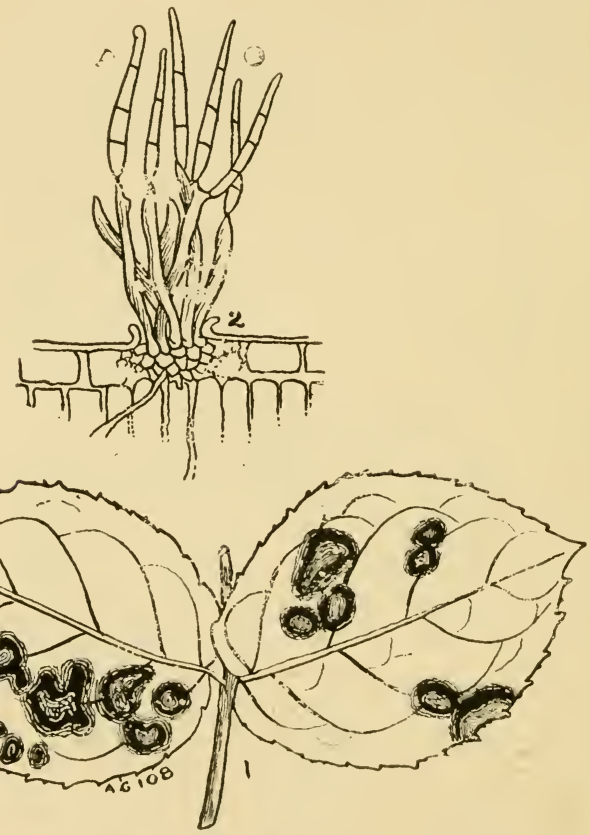

ROEE LE.IF SCORCH.

1, Leaflets badly attacked by the fungus, nutural size; 2, Section of portion of a leaf, showing a fruiting tuft of the fungus, multiplied by 400 .

knowing this, a remedy has been found and long applied in the shape of sprinkling the leaves with flowers of sulphur. Another good remedy to get rid of the mildew is to close the house about eight o' lock in the evening, run the temperature up to 75 deg., then with the bellows fill 
the house full of sulphur, let the house remain closed until it reaches 8.; to 90 deg., then admit air gradually. A constant circulation of air is likewise recommended for roses at all times.

Remenies.-Potassium sulphide one ounce to five gallons of rain water sprayed upon the plants has proved an effective remerly. Spraying in winter, too, with the Cupram Formula (No. 25) would prove a good preventive remedy. Rosarians, from long experience, have come to the belief that rose mildew is induced by a weak condition of the plant, resulting from partial starvation, irregular or excessive watering, and undue exposure to draughts of cold air. The best successes in rose growing, as in other things, attend those who give constant intelligent care to the many details.

Rose Leaf Scorch (Septoria rose).-This disease is caused by a fungus which manifests itself first in the form of yellowish patches, which eventually change to a brownish tint, margined by a darker tint. The mycelium penetrates the cells, stops the circulation of the sap, and causes the affected portions to die and fall out, leaving holes in the leaves. As this fungus is common on wild roses and brambles, it readily finds its way on to garden roses.

Resedies.-Spraying the trees in winter with a sulphate of copper solution (Formula No. 26) will kill the winter form of the fungus, and an occasional spraying with sulphide of potassium in spring and summer will keep the trees free of this pest.

Rose Rust (Phragmidium subcorticatum). - The genuine rust of the rose, similar to the rust of wheat, oats, and other grasses, is not common in this country upon indoor roses. It is not unlikely that it may become a pest here as it now is in California and other States in the Union. Those who are familiar with the rust of the blackberry need no further words of general description of this fungus. 
It protuces a mass of orange-coloured spores on the foliage.

Remenes. - There is very little to be said in the way of treatment save that of cutting and burning all affected plants.

The Black Spot (Actinonema rosa, Fr.).-The Black Spot is a very widespread and conspicuous disease of the rose, first described in 1826, 110 linown in many countries and often much dreaded. The foliage when attacked soon develops the characteristic black spots, and the leaves becoming elsewhere pale shortly fall to the gromm. Is a result rose houses badly infested with the black spot show but iew leaves and fewer blooms. Once trees are badly attacked there is no remedy except to remove and burn the infected leaves.

Remedies. - As a preventive, spray periodically in spring and summer with a solution of sulphide of potassium; also in winter with the Cupram Formula (No. 25). If many leaves have fallen from the plants they should be gathered up and burned. As with many other diseases, some varieties are more liable to the black spot than others. When possible-that is, when all other things remain the same-it is. of course, wise to grow those least susceptible to the discase.

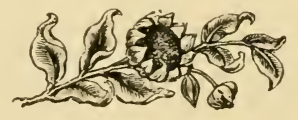




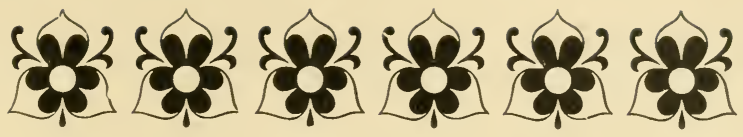

\section{Part V.-GREENHOUSE FOES.}

\section{CHAPTER I.}

\section{INSECTS, MITES, ETC.}

Ants. - It will scarcely be necessury to waste time or space in the description of these, because they are well known-or ought to be, at any rate-to everyone. IVe will only say that the injuries they are usually responsible for are of a two-fold character. In the first place, they gain ingress to the roots of plants in pots, and form tumnels in the soil, causing the latter to become light and spongy, waterlogged, and sour; and, in the second, they do an infinite amount of harm in tramsporting Aphides and young Scale to rarious plants simply for the sake of securing the sugary secretions which exude from their bodies. Aphides are called the milch cows of the ants, from the fact of the latter carrying them about and tending them for the object above mentioned.

Resenies.-In the case of infesting the soil the simplest reniedy is to immerse the pot entirely in water for a few hours and thereby drown the ants. Another good and simple plan is to place a piece of camphor of the size of a hazel nut in two quarts of boiling water, and when cold apply the solution to the soil. Both are perfectly 
safe remedies. 'To prevent ants ascending the stems of plants tie a piece of cotton wool, or simply make a chalk line round; ants will not pass over chalk. Ants may also be trapped by laying marrow bones or pieces of hollow cane about. Examine these daily, and if any ants are found in or on them, dip in boiling water. Pieces of sponge saturated with treacle will attract ants, and so will sheets of paper smeared with treacle. Carbolic acid diluted with ten times, and paraffin with six times, its bulk of water poured into the haunts of ants will drive them away, but this remedy must not be adopted in close contiguity to the roots of plants, otherwise it will kill them. If the nest can be found, make a hole 6in. deep, pour in a tablespoonful of disulphide of carbon, and close the hole with soil. The latter is inflammable, so do not use it near a light.

Aphides. - These are well-known pests, under the common name of Greenflies. There are about a dozen species that infest trees, plants, fruits, and regetables, but the only one that concerns us here as infesting greenhouse plants is the Common Greenfly (Rophalosiphon Dianthi), and the Black Aphis (Aphis fabre), which attacks chrysanthemums. Although commonly called Greenflies, they are not, as their name would imply, always green in colour. It is only when feeding on green leaves or shoots that their bolies are green; on dark-coloured shoots they are usually brownish, or reddish, or dark. "They have brown antenna, transparent iridescent wings, soft bodies, and long legs, and are furnished with a beak with which they penetrate the epidermis of the leaf or the rim of the shoots and suck the jujces of the plant. Aphides are possessed of marvellous fecundity. In the autumn eggs are laid by oviparous females, which lay dormant until spring; then they hatch into flies, which in their turn lay eggs also. From the latter are hatched a progeny possessing viviparous habits; and henceforth until the autumn generation after generation of Aphides are born 
alive to prey upon regetation and annoy the gardener. We have it on the authority of Reaumur, that a single female Aphicle in the course of five generations is capable of being the progenitor of no less than 6,000,000! It is not only by sucking the juices of the plant that injury is done. As the insects increase in size they sherd their skins several times, and these, in conjunction with the excreta and the saccharine matter exuded from their bodies, seal up the stomata or pores of the leaves, prevent their healthy functions being carried out, and attract sooty matters and fungoid spores from the atmosphere, which render the plants unhealthy.

Remedies. - The primary remedy is fumigation with nicotine, in some of its many forms, on two successive evenings. Personally, we much prefer this method to that of syringing with liquid insecticides. Properly rlone, the fumes will penetrate every crevice of the house, and destroy every other living insect in addition to the Aphides. Next to fumigation, the best means is by the application of solutions of some of the advertised liquid insecticides. Of home-made insecticides there is probably nothing better than soft soap and quassia. Four ounces of the latter has to be boiled in a gallon of water for fifteen minutes, then have an equal weight of soft soap added, and allowed to get cool, after which the clear portion can be applied by means of a syringe or sponge. Larger quantities can be prepared at the same rate. Other good preparations are an ounce of carbonate of ammonia dissolved in a gallon of soft water; soda and aloes at the rate of two pounds of the former to an ounce of the latter, dissolved in a gallon of hot water and applied when cool; one part of gas-liquor to five parts of water; four ounces each of aloes and soft soap to a gallon of water; soft soap at the rate of $9 \mathrm{lb}$. to 12 gallons of soft water; and tobaceo water marle by soaking $1 \mathrm{lb}$. of shag tobaceo in six gallons of hot water, then arlding $\frac{1}{2} 1 \mathrm{lb}$. soft soap and applying when cool. In any case, bear in mind when using liquid insecticides not to let them touch the flowers; and, moreover, see 
that they are applied both under and orer the leares. It is also a safe plan to syringe the foliage half an hour afterwards with clean water; the insecticide by that time will have done its work, and there will be no risk of injury to the foliage. There yet remains a brief reference to be made to the value of tobacco powder as a remedy for the destruction of Aphides. Tobacco powder is finelyground tobacco, and in this state is a powerful factor in the destruction of insect pests, especially Aphides; a little of it has only to be applied by means of a distributor to the portions of shoots or leaves infesterl to ensure the speeds destruction of the Greenfly.

Bulb Mites. - Fortunately, these have not as yet proved very numerous, though it must he admitted they are formitable pests. They belong to the spider family, and are not true insects. Owing to their small size-1-20 inch in length, and to their habit of concealing themselves within the scales of the bulbs, they are rarely seen except when sought for by experts. Their bodies are transparent, of a milky-white colour, with a dark oval spot on each side. They are particularly partial to the bulbs of the eucharis, hyacinth, vallota, and many other plants. Bulbs of any kind that become unhealthy should be carefully examined with a strong lens to see if the mites are the cause of their sickly condition.

Remanies. - So far no definite remedy is known. Several have, however, been tried with partial success, and among these may be mentioned that of soaking the bulbs a few moments in water heated to a temperature of 140 deg. Fahr.; washing off all loose soil, remoring diseased scales, and carefully brushing the bulbs with a solution of Encharis Mite Destroyer, or tobacco water, prepared as advised for Aphirles. All the soil previously occupied by the bulbs shonld be burnt, and the crocks and pots soaked in hot water to prevent the mites reaching other bulbs.

cockroaches. - These are exceedingly lively and crafty inserets, which feed chiefly on the roots of plants, 
especially of orchids. They are also not adverse to devouring seedling plants. Being nocturnal feeders, it is difficult to catch them; besides, they have a habit of concealing themselves beneath pots, or anything else they cin crawl under or into, directly light is introduced, or as soon as daylight appears. It is hardly necessary to describe them in detail; they are pretty well known.

Remenies.-Phosphor paste or beetle poison, spread on slices of bread placed about the greenhouse, will generally prove effectual in destroying them. They may be caught in ordinary beetle traps, or in bottles partly filled with beer and water and sunk in the earth; or in shallow

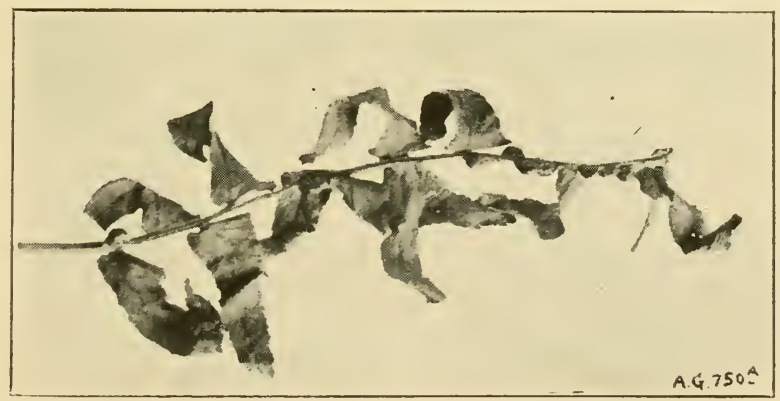

[Photo: H. A. Smith.

FERX FROND INFESTED WITH BROWX SCALE. The scales can be seen adhering to the midrib.

vessels containing beer placed under or on the staging. Fresh rhubarb leaves laid about, and a mixture of oatmeal and salt, are said to be efficacious remedies.

Crickets.-The House Cricket (Gryllus domesticus) sometimes attacks the roots and young shoots and leares of greenhouse plants, but cannot be looked upon as a rery troublesome pest to the gardener. Like the Cockroach, it is a nocturnal feeder, and hence is never seen by day 
unless its hiding place-generally a warm crevice near the hot-water pipes or flues, where, by the way, the Cockroach makes its rendezvous also by day-is accidentally discovered. Unlike the Cockroach, however, its presence may generally be detected at night by the peculiar chirping noise of the male calling for the female.

Remedies.-For these see under Cockroaches.

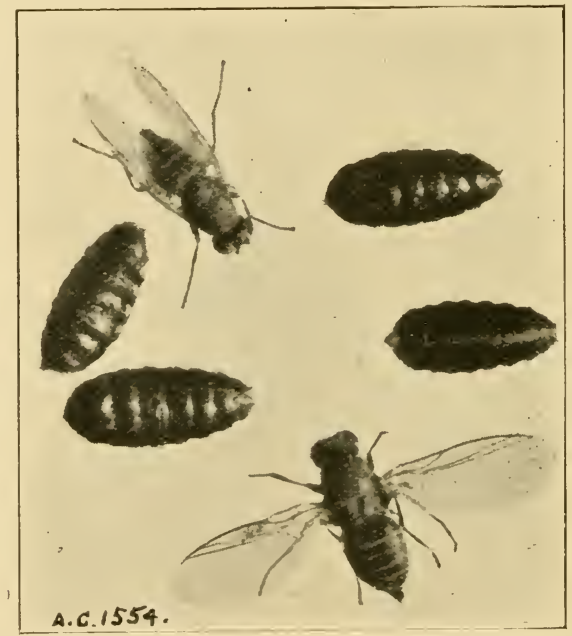

MARGUERITE FLY IND PUPE (ENLARGED EIGHT DLAMETERS).

Fern Pests. - Thrips are liable to infest ferns, and to do much injury to the fronds. Scale insects, too, are often troublesome, fixing themselves to the surface of the fronds, also to the stems and midribs. Cockroaches are partial to the young fronds. Mealy Bug occasionally infests the fronds, and Aphides the young fronds of the Maidenhair fern.

Remedies.-Fumigate slightly on several successive evenings to destroy the Thrips and Aphides. Detach the Scale insects with a piece of stick, and sponge the parts 
with an insecticide. Lay down poison for Cockroaches, and sponge with an insecticide to eradicate Mealy Bug.

Leat-mining Maggot.-The larve of the Marguerite Leaf-mining Fly (Phytomyza affinis) frequently do considerable injury to the leaves of the chrysanthemum and marguerite by boring small channels between the two surfaces. The maggots feed on the soft tissues, cause blisters and whitish zigzag tunnels to form on the

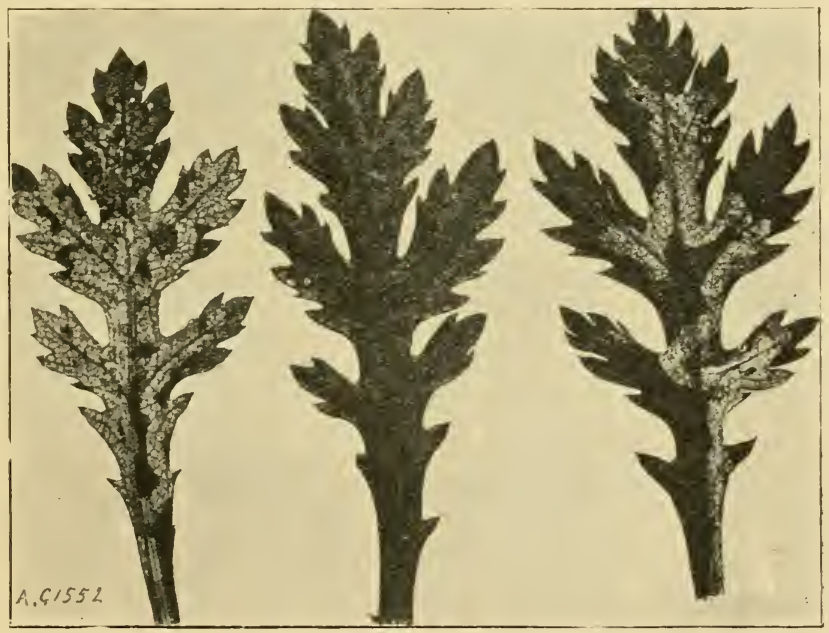

LE.ITE: IXJURED BY MARGUERITE FLY L.IRTE.

surface. When very numerous the functions of the leaves are seriously disorganised, and the health of the plant badly affected. The fly is like the Common House Fly in shape, and of a dark, slaty-black or ash colour. It measures one-fifth of an inch in the spread of its wing, and about one-twelfth of an inch in length. The flies appear in May and June, and deposit their eggs, by means of an ovipositor, in the cuticle of the leaf. When fully 
grown the maggots do not quit the leaves, but form chesinut-brown coloured pupae in the mines, and eventually emerge therefrom as perfect flies.

Revedies. - When the maggotis are seen in the leaves it is useless applying insecticides, as anything powerful enough to reach them would at the same time lill the leaves. The only remedy in such a case is to either pinch off and burn the infested leaf, or to crush the maggot between the finger and thumb in the leaf, or to pick out each grub with the point of a penknife or darning-needle. As a preventive, syringing the foliage frequently during May and June, when the flies are on the wing, with a paraffin solution, is a first-rate plan. The solution should be prepared as follows: Place a piece of bath brick in a wooden pail, and pour as much paraffin oil thereon as it will soak up. Fill the pail with water, and leave it for three or four days, then remove the scum from the surface, and syringe, or, better still, spray the foliage thoroughly with it in the evening. Prepared thus, the essence of the oil is thoroughly communicated to the water, and 110 injury will be done to the foliage. The oiled surface acts as a deterrent to the fly depositing its egrgs.

Mealy Bug.-This is a well-known greenhouse pest. The males are small, with long antennic, pale red in colour, and covered with white powder. The females have shorter antemne, no wings, a longer body than the male, red in colour, and covered with white meal. The latter are very active whilst in the growing stage, and move freely about from place to place. When the eggs are laid they are covered with a cottony substance, which is exuded from the skin of the female insect. The most common species is Dactylopius longispinus. Like their relatives, the Scale insects, they puncture the epidermis of the leaves or shoots, and extract the sap.

Remenes. When the Mealy Bug has gained an entrance into a greenhouse it is not easy to eradicate it. 
Washing the shoots and leares with solutions of liquid insecticide, or syringing with an emulsion of soft soap, petroleum, and water, prepared by dissolving four ounces of soft soap in a gallon of boiling water, then adding a third of a wineglassful of petroleum, mixing the whole thoroughly well together and using when cool, are the usual and most efficient remedies. If syringing is not a convenient method of applying a liquid insecticide, place

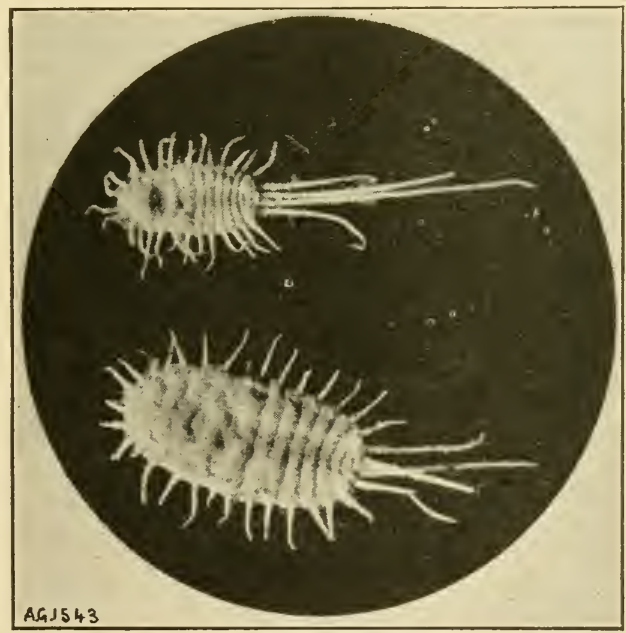

[Photo: J. G. Blakey.

MEALY BUGS (DACTYLOPUS LONGISPINUS).

Showing femalee in different stages of derelopment.

the solution in a good-sized tub, and then, grasping the pot with one hand and the plant with the other, dip the foliage several times in the solution. This methor is a more economical one than syringing for ridding small plants of minute pests, as there is little waste of the solution employed. To destroy Mealy Bug in bunches of flowers, tie a small piece of sponge on the end of a smali 
stick, dip this in a small phial of spirits of wine, and just touch the bug with it. The spirit must not be allowed to touch the blooms or stallis.

Orchid Pests. - The chief pests that infest orchirts are Aphides, Thrips, Mealy Bug, Scale, Woodlice, Red Spider, Cockroaches, the Dendrobium Beetle (Xyleborus perforans), and the Cattleya Fly (Isosoma orchidearum). The Dendrobium Beetle is about 1-12in. in length, and of a chestnut-brown colour. It perforates the stems of rendrobiuns and forms tumnels in the centre, feeding on the inner tissues. The Cattleya Fly deposits its eggs in the eye of the young growths when domant, and causes the latter to become stunted.

Pinmedies. - The only remedy for the Dendrobium Beetle is to cut off and burn infested growths, and in the case of the Cattleya Fly to cut off the stunted growths, split them open, and remore and destroy the yellowish grubs, the larva of the fly. Sometimes the grubs infest the roots, causing warty swelings to form. In this case dig out the grubs with the point of a penknife or needle. The othor pests are freely dealt with in preceding paragraphs in this chapter. To prevent Slugs and Snails ascending the flower stems, tie a piece of cotton wool around them.

Plant Bugs.- Several kinds of these are hurtful to the buds of the chrysanthemum. The one we shall specially mention here is Anthocolis inemorum. 'The perfect insect measures one-eighth of an inch in length; head and fore part of borly shiny black; feeler's yellow, with black tips; legs yellow, with a black band round the hindermost thigh; feet black; wings brownish-yellow. It punctures the buds and prevents them opening properly. Occasionally it does goor, however, by feeding on aphides, but it is doubtful if its gool qualities outweigh the injury done to the buds. It is a very active insect, jumping off with alacrity when risturbed. Another species of Plant Bug, Calacoris bipunctata, frequently does much harm to the 
buds and leaves of chrysanthemums. This insect is like a large aphis in shape and colour, and measures just under a quarter of an inch in length. It punctures the epidermis of the young leaves and the points of the shoots, causing them to turn brown and shrivel. Yet another species, Phytocoris campestris, is reputed to injure chrysanthemum buds, points of the shoots, and young foliage, the parts attacked having the appearance of having been poisoned. Wherever the shoots wither, turn black, or eurl up rery much, it may be taken for granted that one of the foregoing pests is the culprit.

Remedies. - To eatch the bugs hold a butterfly-net or a cloth in front of the plant, and suddenly, but carefully, shake the shoots over this. The bugs will fall off immediately. Svringing with one of the remedies advised for Aphicles will also prove effectual.

Red spider.-This is a formidable plant pest, and one usually very prevalent in greenhouses where sufficient attention has not been paid to moisture and rentilation. It is a minute creature, orange or red in colour, and much resembling a spider in miniature. It is popularly spoken of as an insect, but it is not; it is a mite. Like the true spider, it also spins a web on the leaves on which it feeds. It first cuts a hole in the leaf by means of its mandibles, then thrusts in its sucker and extracts the juices. Hundreds and thousands of these are often to be met with on a leaf, protected by a fine web. Needless to say, such a large number of these creatures in a small space do an incalculable amount of injury to the foliage by robbing it of its proper nourishment. No wonder, then, that the leaves soon assume a yellowish tinge, become unhealthy, and speedily die.

Pemenies. - I hot, dry atmosphere is favourable to the increase of Red Spider; consequently, the best way to keep it at bay is to proserve, as far as possible, a moist atmosphere by suringing the walls, foliage, and paths daily; or, where this cannot be done, by sprinkling flowers 
of sulphur on the heated hot-water pipes. Where leaves are badly infested they should be sponged with soft soap and water. Leaves that have a sickly hue should always be carefully examined on the under sides, taking, at the same time, prompt measures for the destruction of any lied Spider found thereon. Plant houses liept clean. moderately moist, and properly ventilated, are rarely infested with Red spider.

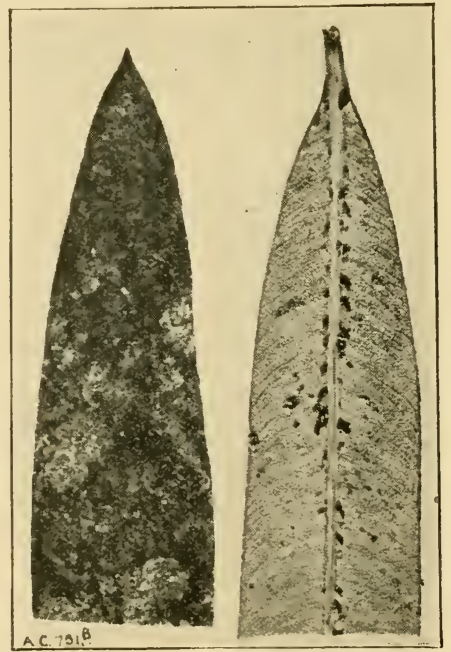

[Photo: H. A. Smith.

ACMLE INSECTS ON OLEANDER LEAVES. teaf.

The incects may be seen fixed to the sides of the midrib of the back of the

Scale Insects. -There are several kinds infesting greenhouse plants. The most common species is the Brown Scale. This is a reddish-brown insect, hemispherical in shape, which infests the shoots and stems of a variety of plants. The young Scale cling very closely to the shoot, and are somewhat soft; the older ones have 
a shining shield-like skin, which, when the female has laid her eggs and she dies, serves as a covering for the young Scale. For the first day or two after hatching the young Scale move about to find a suitable feeding place, then they firmly attach themselves to the shoot by their suckers, and never move afterwards. It is during this stage of their existence when the ants make themselves busy in distributing the young Scale about. There is also the Orange-tree Scale, a flat species, which punctures the shoot to such an extent that the sap falls on the leaves below, and forms the sticky honey-dew that is often found coating their surface. Then there is the Fern Scale, Camellia Scale, Oleander Scale, Aspidistra Scale, Palm Scale, ttc., all fairly common on greenhouse plants.

Remedias. - When plants are badly infested with Scale insects it requires sone drastic measures to remove them. In the case of hard-wooded plants the shoots must be thoroughly scrubbed with a brush and a strong solution of an insecticide like Gishurst Compound. The leaves, too, if infested, must be carefully sponged, removing any Scale not easily detached by a sponge by means of a small pointed stick. Syringing with water heated to $140 \mathrm{deg}$. Fahr. will invariably kill Scale. Tender plants, such as ferns, can only be freed from Scale by first detaching the insects with a pointed stick, and afterwards sponging with one of the liquid insecticides. Fumigation with tobacco is useless, and so is syringing with insecticides, unless done several times in succession at intervals of a few days. Oleanders, oranges, and camellias rery badly infested may be quite cleared of Scale by immersing the plants entirely in water for a day or two. This, howerer, should only be done in summer.

Snow-flies.--The Snow-tly (Aleyrorles proletella) is related to the Aphides, and closely resembles them in form and size, the main difference being that the former are covered with a white powder; their habits, too, and manner of feeding are similar. They are more frequently 
seen on the cabbage than on greenhouse plants, but occitsionally may be met with on the leaves of abutilems and a few other plants. Is soon as seen they should be promptly removed, otherwise they will do much injury to the leaves by sucking the salp). They are very active insects, flying away in a cloud-like mass when disturbed.

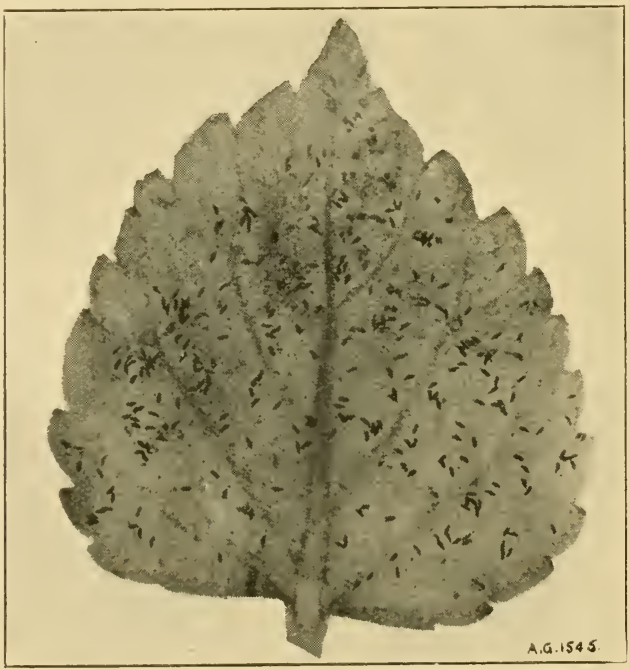

[Photo: J. G. Blaker.

EGGS OF GHOST OR SNOW FLY ON A SALVIA LEAF. The eggs are enlarged seven diameters.

Remenes.-J)usting with tobaceo poweler or flowers of sulphur, and successive fumigations with nicotine, are the best remedies to atlopt.

Springtails.--These are lively little insects, which have been noted of late years as frequently infesting the roots of pot plants. When present in large numbers they moloubterlly slo a great deal of harm to the roots of piants. 
The commonest lind is known as Podura terrestris. It varies in length from 1-30th to $\frac{1}{2} \mathrm{in}$, is of a whitish colour, and more or less hairy. Then disturbed, it jumps or runs away with alacrity. This species frequents damp and sour soils mainly. Other kinds of Springtails which are equally harmful are: Achorutes purparescens, a brownish insect of similar size to the preceding one; and Lipura ambulans, a milky-white kind. They are easily recognised by their habit of jumping or springing when disturbed.

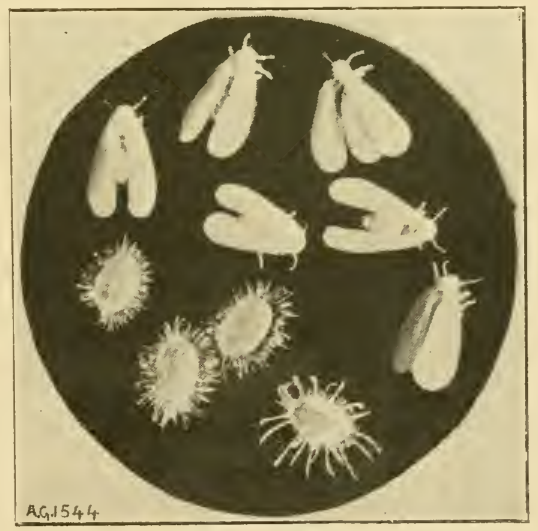

[Photo: J. G. Blakey.

GHOST OR SXOW FLT (ILEYRODES PROLETELLA).

The flies are magnified eight dianetere. Below are the waxen nymph cas: containing the pupæ.

Rexebies.--Immersing the pots and roots in lime water, as advised for worms; watering the soil with a solution of nitrate of sodat at the rate of an ounce per gallon, or with a weak solution of permanganate of potash and water, will destroy these creatures.

Thrips. - There are few insects more destructive than these. The one which attacks the chrysanthemum and other greenhouse plants is Heliothrip hemorrhoidalis, 
a dark brown four-winged insect, with a reddishtipped body, pale yellow eyes and limbs, and measuring 1-20in. in length. It is wonderfully agile in its habits, jumping away directly the leaf it is on is touched. The larva-small whitish or yellowish maggots-are also fairly active, but they cannot jump. Both feed on the surfaces of the leaves and shoots, sucking out the juices, and causing them to assume a yellowish tinge and die. Not only do they injure the leaves, but also the young shoots and flowers. They are especially destructive to the young and tender foliage of orchids. As a rule, they never get very numerous in greenhousos that have a fairly moist atmosphere.

Rementes.- Sponging the foliage, or syringing or spraying with a solution of one of the advertised insecticides, are the usual remedies. Fumigation with nicotine on three surcessive evenings generally proves successful.

Weevils. Both the perfect insects and the larva do considerable injury to plants in greenhouses as well as outdoors. The particular species responsible for the injury to greenhouse plants is the Clay-Coloured Weevil (Otiorhynchus picipes). A fully-developed specimen of this weevil measures about a quarter of an inch long. It is wingless, and the body or chief colour is of a clayish hue, freely spotted with dark warts. The weevils lay their eggs just beneath the surface of the soil, and these speedily hatch into white, legless maggots, having brown heads, which feed during the autumn and winter, and emerge into the perfect weevil the following spring. Owing to the colour of the weevils being similar to the earth, it is almost impossible to detect them in a casual way; and it is next to useless searching the foliage for them by day, as they are then safely hidrlen beneath the surface of the soil. They are nocturnal insects, hence only feed by night. The full-grown weevils feed on the young fronds of maidenhair ferms and on flowers, and the maggots on the roots of plants. 
Remedies.-To catch the weevils, smear a tray or cloth with treacle, then suddenly shake the plant over it, getting someone at the same time to turn a bull's-eye lantern thereon. If there are any weevils present they will drop at once, and may be caught and destroyed by placing them in boiling water. With regard to the larvæ, take pains to free the soil from them before potting; but, if any should be present in the soil afterwards, immerse the pots in water for a few hours and drown them. Some persons advocate the application of a solution of bitter aloes and quassia, but we cannot vouch for its not injuring the roots.

Woodlice.-Several kinds of Woodlice or Slaters are partial to the buds of the chrysanthemum. The Common Woodlouse (Armadilla vulgaris) is the chief kind. This is of a leaden hue, and rolls itself up when disturbed. Another kind, Oniscus asellus, is greyish-brown, with yellowcoloured spots on its sides and back. Yet another, Porcellio scaber, is of a slaty colour, with a rough dotted back. Being nocturnal feeders, they are not often seen at their mischievous occupation, and their handiwork is often attributed to other pests. During the day they hide under dry rubbish or in crevices. It is evident, therefore, that all rubbish should be removed from the neighbourhood of the plants, and that any crerices likely to form a harbour for them should occasionally be treated with boiling water.

Resedies.-Traps, in the form of dirty flower-pots filled with hay or moss, or with their insides smeared with treacle, should be laid about to entice the Woodlice to enter. Examine these daily, and kill all found therein. Potatoes, swedes, or turnips cut in halves, and their insides scooped out, also form excellent traps. Beetle poisons placed near their haunts will be equally effective. Phospho nicotyl (Voss's), a powder preparation, is also a splendid remedy for killing wood lice.

worms. - These unquestionably do a large amount of 
mischief if allower to remain long in the soil of a pot plant. They not only damage the roots, but render the soil spongr, stagnant, and sour, and speedily bring the plant into ill-health.

Remedes. - Put a lump of unslaked lime the size of your fist in a pail of water. Allow the solution to stand

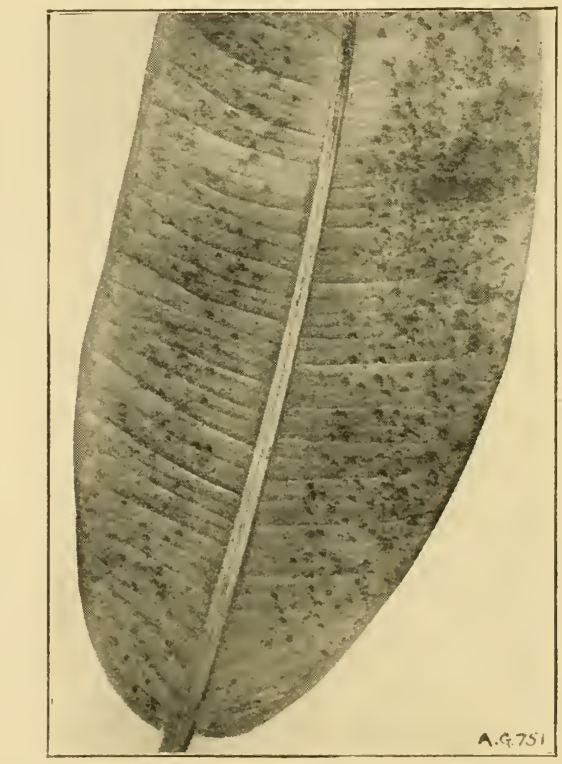

[1 hoto: H. A. Smitl.

DISE.ASED LE.IF OF INDIA-RUBBER PI.INT.

I fungoid disease, probahly a species of Cercospora, which causes pale spots to form on the leaves. In time the parts attacked shrivel and decay and form holes.

twenty-four hours, then skim off any film on the surface and quietly stand the pot infested with worms in the pail. In a few seconds the worms will come to the surface, and may be caught. Watering the soil with a solution of carbonate of ammonia, half a teaspoonful to a gallon of 
water, will effect the same object. Plants in pots should never be stood on the bare soil, but on tiles, slates, boards, or cinder ashes, otherwise worms will readily gain ingress to the roots.

Yellow Orchid Aphis (Siphonophora lutea).Aphides, with greenish-yellow bodies, that infest orchids grown under glass. There are winged and wingless females.

Remenies.-Fumigation with nicotine compounds.

\section{DISEASES OF GREENHOUSE PLANTS.}

Brown Spots and Holes in Leaves.-Aspidistras and palms sometimes have brown spots or holes in their leaves. These are caused by careless sponging or by a Shot Hole Fungus (Cercosporia species).

Penenies.--Always use a soft sponge, quite free from grit. Never attempt to polish the leaves with oil rags, as is sometimes done, and see that the roots are kept in as healthy a condition as possible; then there will be few, if any, brown spots or holes in the foliage.

Camellia Diseases.-The bleached silvery-white blotches, sprinkled with black spots, and sometimes seen on camellias, are caused by a fungus called Pestalozzia Guepini. Another fungus, Camellia Black Mould (Macrosporium camellixe) also forms similar blotches, but with a definite brown margin.

Pinmedy.-Pick off and burn diseased leaves. 
Chrysanthemum Leaf Rust.-This is a pest which has only manifested itself of recent years. At one time it threatened to practically exterminate the chrysanthemum, so virulent did it become all over the country. Thanks, however, to the united and vigorous efforts of growers, the Rust was greatly checked in its course, and now we only hear of it occasionally. It is scientifically known as Puccinia hieracii, and is a near relative of the Hollyhock Fungus. This fungus is not confined to the chrysanthemum only; it is prevalent on our native hawkweeds, thistles, groundsels, burdock, and knapweeds; consequently, wherever these weeds abound. there is always risk of the fungus finding its way, either by the agency of winds, birds, insects, or human beings, to the chrysanthemums.

The life history of this pest is, briefly, as follows: It is propagated by what are known as summer or winter spores. The former, technically called uredo-spores, consist of the brownish or snuff-coloured spots found on leaves inferted with the fungus. The spots may be dispersed singly about the surface of the leaf, or congregated in masses thereon. In any case, there are myriads of them, and these are distributed about by one or more of the agencies previously mentioned. When a spore alights on a leaf, and the conditions are congenial, it develops in eight to ten days, and gradually takes possession of the leaf, finally causing its ill-health and ultimate death. The winter spore, technically called the telutospore, differs from the summer spore in not germinating the same season. It either remains on the leaves or falls on the soil, and remains inactive till the following spring, when it levelops, and begins to again spread the disease anong the plants. It will thus be seen that the Leaf Rust may make its appearance on plants in early summer through the summer spores being conveyed to the foliage by insects, birds, winds, or the clothing of persons who have previously been in contact with weeds or with chrysanthemums infected with the disease. Or some of the 
winter spores may be present in the soil used for striking the cuttings, or on the leaves of the cuttings, and these have given birth to the Rust. The worst of pests of this kind is their presence is not discovered until too late to prevent them injuring the foliage. The spores, when ger-

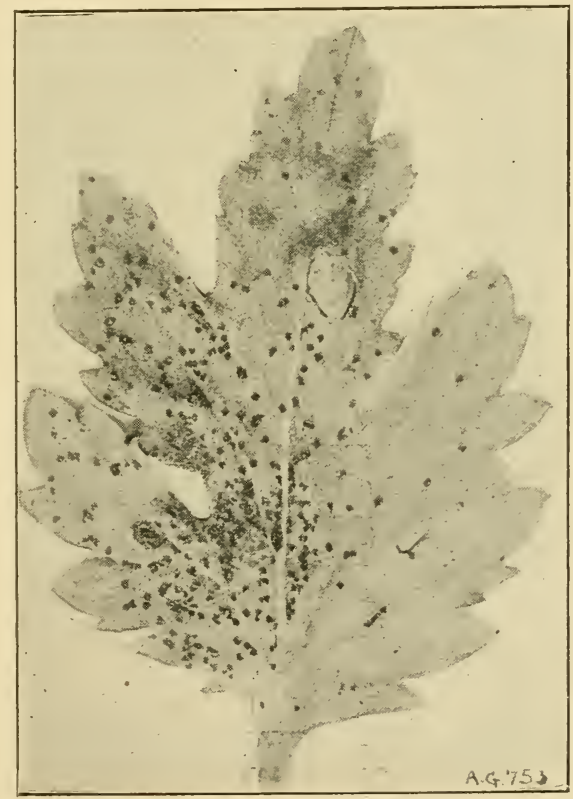

[l'hoto: H. A. Smith.

CHRYSANTHEMUM RUST.

The dark spots on the back of the leaf are the pustules of the fungus (Puccinia hieraceii).

minating, penetrate the delicate leaf tissues with their mycelium, rupture the cells, and put a stop to the development of the leaf. The brown spots really indicate the fungus in its full stage of development; they are the fruit of the fungus. 
linmentes. - Is to remedies, it is obriously useless to apply thein when the leaves are covered with the brown spots, as the mischief has then been wrought. All that can be done then is to promptly pick off and burn every infected leaf. Directly afterwards spray the foliage with a solution of sulphide of potassium at the rate of an ounce to two and a-half gallons of tepid water. The liquid should be applied to the under and upper sides of the foliage, and allowed also to fall on the soil in the pots and on the ground, to make sure of destroying fallen spores. This may prevent the fungus spreading. To guard against an attack, the plants should be regularly sprayed every ten days throughout the season. If this plan be adopted, and all infected leaves or very badly attaclied plants be promptly burnt, the much-dreaded Leaf Rust may be kept at bay. Great care should also be taken not to propagate from infected plants.

Chrysanthemum Leaf spot.-Occasionally the leaves of the chrysanthemum are infected by dark brown spots, which seriously disfigure and weaken the growth of the plants. This particular disease is caused by a fungus called Septoria chrysanthemi. But little is known of its life history at present. Other species of the genus, however, inflict similar injury upon the currant, parsley, and tomato.

Remenies.-One thing is certain: It is wisc, wherever leaves are found with dark brown spots, to at once remove and burn them; afterwards spraying the foliage thoroughly with Sulphide of Potassium solution (Formula No. 23) as a preventive against a second attack.

Chrysanthemum Mildew.-A form of mildew peculiar to the chrysanthemum, and scientifically known as Oidium chrysanthemi, also loes much lamage to the foliage in some seasons. This mildew spreats over the leaves, and also the petals of the blooms, sending its slender tubes into the cells, and speedily disorganising the fun stions of the plant. It is easily recognised by the 
greyish-white film of growth spread over the surface of the leaf. Plants that are much crowded, and do not get sufficient light and air, are specially liable to an attack.

Remedies. - Spraying with the sulphide solution advised for Leaf Rust will destroy the mildew, and also prevent it again infecting the foliage. Dustings with flowers of sulphur will also prove effectual. Extremes of temperature, when the plants are housed, should also be avoided.

Damping-off Disease.-Every plant-grower has at some time or other had the mortification of seeing valuable seedlings wither and fall over on their sides in the seedpot or box. The stems shrivel just at their junction with the soil. This is caused by a fungus technically known as Pythium de Baryanum. It appears to infest soils that are liept too moist.

Remedies.-Directly the seedlings show signs of attack pull out the infected ones and dust sulphur among the remainder. Stand the pan, pot, or box in as light a position as possible, and do not water too freely.

Mildew.-There are several kinds of mildew attacking greenhouse plants, but all are pretty much alike, and amenable to the same course of treatment. Nikew is a name commonly applied to several kinds of minute fungi of a parasitic nature, and which grow upon the leaves or shoots of plants. Seen under the microscope, they consist of slender threads which spread over the surface of the leaves, and here and there put forth suckers which penetrate the cells and thus thrive on the sap. In due course these minute parasitic plants bear millions of spores, which are carried by the agency of the wind to other plants, and hence the fungus spreads very rapidly if not checked. Mildew, as seen by the naked eye, is a dense whitish mould. It generally makes its appearance in greenhouses kept too dry or too moist, and where proper attention is not paid to ventilation.

Revedies.-Avoiding extremes of dryness and moisture, both in the atmosphere and at the roots of the plants, is 
a safe preventive. Strict attention, too, should be paid to ventilation, never allowing cold currents of air to come in direct contact with the foliage, especially of roses. In the event of mildew appearing, dust the affected foliage with flowers of sulphur, and after moistening the hotwater pipes dust these with sulphur also. Instead of the sulphur the following recipe may be used: Boil 1lb. of sulphur and 1lb. of quicklime in five pints of water for ten minutes in an earthenware pot; lieep well stirred. When cool, strain off and add one part of this to a hundred parts of water, and apply it to the infested plants by means of vaporiser or a diffuser. A solution of sulphide of potassium, prepared by dissolving one ounce of the latter in a quart of hot water, then adding the liquor to two and a-half gallons of water, is also an excellent prerentive or cure for mildew. Apply by means of a sprayer or a syringe to both sides of the leaves. In applying the solution aroid allowing it to touch any painted surface, as it will damage the paint. If a syringe be used see that the solution is ejected with as fine a spray as possible. Painting the hot-water pipes with a solution of hot lime and sulphur-a quarter of a pound of each to three gallons of water-will also help to eradicate mildew.

Orange Mould.-'The leaves of oranges and other evergreen greenhouse plants are sometimes covered with patches of dark mould. This is the work of various minute fungi, which develop on the honey-dew deposit formed on the surface of the leaves by rarious insects. If the mould is allowed to remain long on the leaves it seals up the stomata, or breathing pores, and causes the leaves to become sickly.

Remedies.-The foliage of the plants should be frequently sponged, so as to remove the honey-dew deposit. Insects also shoukd not be allowed to infest the plants.

Orchid Diseases.-A few diseases attack orchids. First of all, there is the Leaf Spot (Leptothyrium perniciosum), which forms brownish spots on the leares The 
spots ultimately become bleached, and the parenclyma dries up. Then there is the Orchid Anthracnose (Gloeosporium Bidgoodii), which causes the ends of the leares of odontoglossums to become pale, and spots to form on other parts of the leaves. These are about the only two of any consequence.

Resedy.-Cutting off and burning the diseased leaves seems to be the only one.

Sclerotinia Disease.-This fungoid disease, scientifically called Sclerotinia sclerotiorum, attacks a number of plants, including the chrysanthemum. It first appears in the form of a white mould on the stem, just above the soil. As the fungus develops it penetrates the stem, causing it to become brittle and to split, when the interior will be found more or less full of black sclerotia.

Remedies. - Fortunately, it is not a very common enemy of the chrysanthemum, but whenever a plant is found to be attacked it should at once be cremater. Should the white mould stage of the fungus be found on the stem, dust freely with slaked lime.

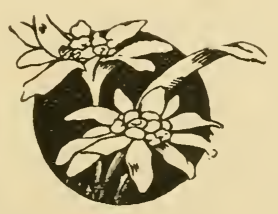




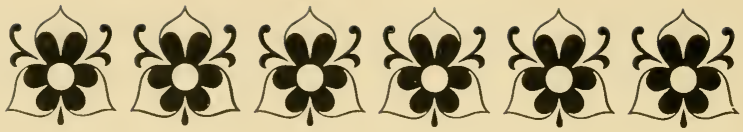

\section{Part VI._FOREST TREE FOES.}

\section{CHAPTER I. \\ I N S E C T S.}

Ash-bark Beetle (Hylesinus fraxini).-Both the beetles and their larva bore tunnels just beneath the bark of ash trees, thus interfering with the circulation of the sap, causing the bark to decay and the tree to eventually die. The beetles are 1-6in. long, blackish to ochreous in colour, with red feet. The larva are small, white, fleshy, and legless, and furnished with strong jaws. The beetles appear in April, and bore holes in the bark; then lay their eggs, the larva from which bore short tunnels at right angles to the main tunnel on each side. In due course the larvie turn into pupae, and finally emerge as beetles, eating their way out and riddling the bark with holes.

Remenes. - (1) Trees barlly attacked should be cut down and have the infested bark stripped off and burnt. In April and May paint the trunks with the remedy adrised for the Fruit 'Tree Beetle on page 66.

Ash-bark Scale (Chionaspis salicis, syn. A. fraxini). -Although its common name is popularly associated with the ash, this Scale insect really derives its specific name from the willow. It is common on both trees, and is also 
occasionally found on the elm, maple, and alder. The female scales are of a dull crimson colour, and the larve and ova are of a similar colour. Like other scale insects, the adult females attach themselves permanently to the bark, and during their short life suck out the sap from the tree. The newly-hatched larve crawl about the bark until they have discovered a suitable feeding place, then settle down permanently in that position. There are winged and wingless males, and these may be seen actively mor-

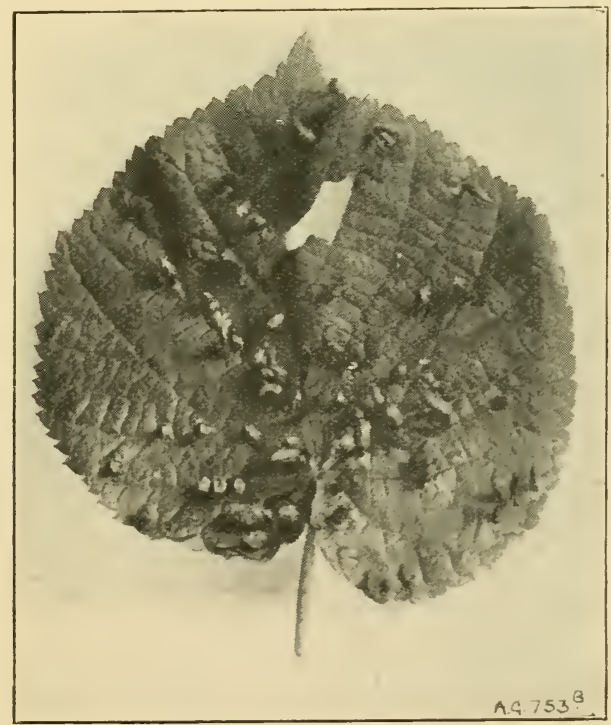

[Photo: H. A. Simith.

NAIL G.ALL ON LIME LE.IF.

The tiny galls ara caused by a midge named Eriophyee tiliæ. Fairly common on lime trees.

ing about early in July. When a tree is badly infested with this pest it soon becomes unhealthy and stunted in growth.

Remedres, - Tee Beech Scale for these. 
Beech Scale (Cryptococcus fagi).-Insects belonging to the Scale family. The female is lemon-yellow in colour, wingless and legless, and measures 1-25in. in length. In a young state the insects move freely about the bark, but when they attain maturity they fix themselves permanently to it, suck out the sap, and clothe themselves with a white felted secretion of filaments of wax. The females are parthenogenetic, and produce their young without the assistance of the maies, which are unknown.

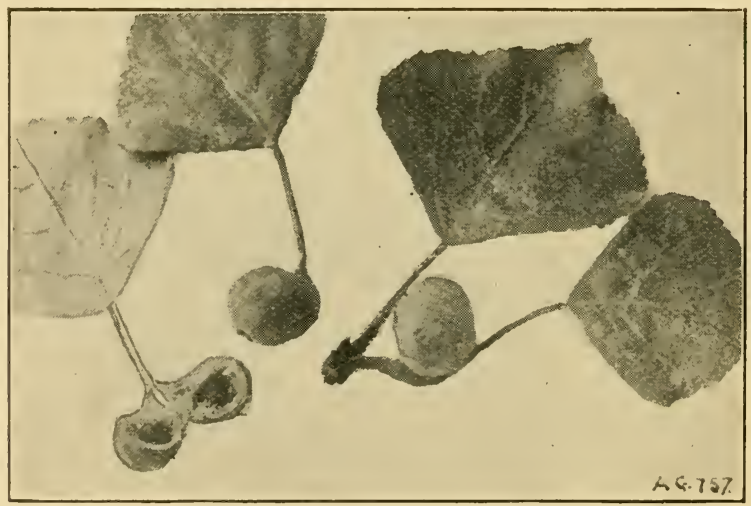

[Photo: H. A. Emith.

I'OPLAR-LEAF STALK GAIL (DILLOSIS TREMUIAE).

The galls are formed by midges at the base of the leaf petioles as shown.

likmenes. - These must be of a drastic character, and be promptly applied before the tree is too far crippled. spray the tree thoroughly with Formulie Nos. 1 or 2 in winter. Spray for two or three successive seasons untii the scale is obliterated.

Buff-tip Moth (Pygara bucephala).-The caterpillars of this moth are very partial to the leaves of the lime, oak, and elm, and when very numerous will often strip 
the branches entirely of leaves. The moth is a fairly large one, has fore wings of purplish-grey with a huff patch at the tips, and whitish hind wings. It lays its eggs in June in groups on the upper sides of the leaves, and the caterpillars hatch in about fourteen days. When full grown they measure nearly $2 \mathrm{in}$. in length, are furnished with silky hairs, and have yellow bodies, lined with black and orange. On reaching maturity they descend to the earth

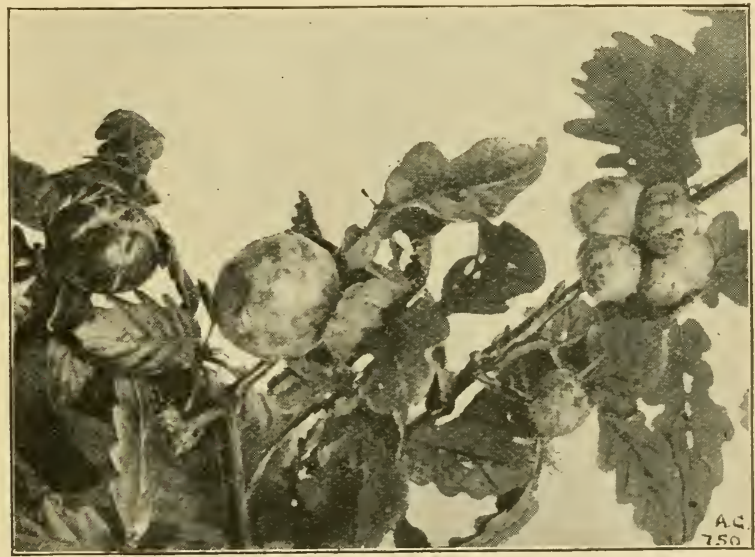

[Photo: H. A. Smith

"OAK APPLE" GALLS ON OAK.

Formed by the larvæ of a midge (Teras terminalis) puncturing the rind of the shoots.

to change into pupie, emerging as moths the following June.

Remedies.-(1) Spread cloths or sheets under infested trees, and vigorously shake the latter; then the caterpillars will drop off and be easily caught. (2) Spraying the trees in July with a Soap and Quassia solution (No. 14) will get rid of them also.

EIm-bark Beetle (Scolytus destructor).-The beetles and larve do injury to the bark of the elm similar to that 
described in connection with the Ash-bark Beetle. The beetles are black, one-eighth of an inch long, have pitchy legs, and redrlish foet. The larve are fleshy, legless, wrinkled, and whitish in colour. The fermale beetle lays its eggs in crevices of the bark in June, and the larve bore short tumnels at right angles to a central one, work-

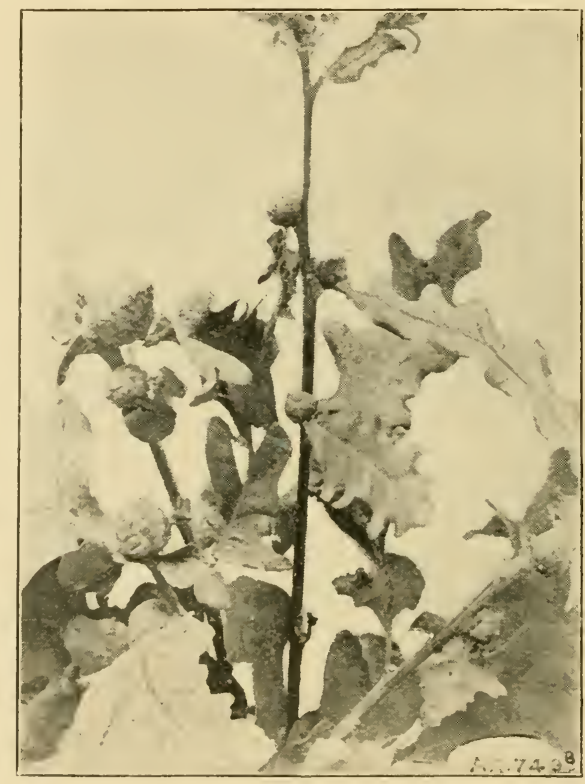

[Photo: H. A. Simith.

HOP OR AR'TICHOKE GALLA ON AN O.IK.

The galls are hop or Gloke Artichoke shaped, and formed in the budo of the shootis.

ing on both sides in the soft bark. They are fully fed by July, then turn inte pupie, and come forth as beetles in August. If very numerous they soon kill a tree.

lievedes.--(1) Spraying the bark with a Kerosene Emulsion (No. 16) in June and July, and again in August when 
the beetles come out. (2) Spraying in winter with Formulie Nos. 1 or 2. (3) Cutting down and burning the bark of badly-infested trees.

Galls on Oak Leaves, etc. - On the leares of the oak, lime, willow, and rose, fleshy protuberances may often be seen. These do no serious harm, however, to the trees unless very prevalent, in which case the growth of the tree is frequently seriously crippled. The principal linds of galls are: Marble Gall, or Oak Apple; Common Spangle Gall ; Currant Gall; Nail Gall of the Lime; Horsebean Gall of the Willow; and the Bedeguar Gall of the Dog Rose. Each of these galls owes its existence to the larva of small wasps or flies. The latter lay their eggs in the leaves, and the larve feed upon the sap, and gradually cause the tissues to grow around them and form the curiously-shaped excrescences. We cannot afford the space to give a detailed description of each.

Remedies. - Suffice it to say that these galls should be cut off and burnt when seen, to prevent the larvie developing and becoming more numerous in future rears.

Gipsy Moth (Liparis dispar).- The male moths have brown wings and the females grey ones. On the fore wings are short brown stripes with spotted fringes. They appear in July and August. The eggs are laid during those months, and these hatch in April and May The larve are light grey, speckled with dark grey, and have a yellow head marked with black. On each of the first five segments are a pair of blue tubercles, and on the remaining segments the tubercles are blood-red. On each tubercle is a tuft of hair, and there are yellow marks on the sides of the body. The larvie appear from April to July, and feed on the foliage of the apple, pear, plum, nak, lime, ete, often doing serious injury thereto.

This pest must be reported at once to the Board of Agriculture inspector, as adviser in Chapter I'.

Holly Leaf Miner (Phtomyza illicis).-The leaves 
of the holly are frequently much disfigured by irregular pale blotches on the surface. The latter are caused by the larvie of a small fly which eats the cellular tissue, leaving the outer slins only. The fly deposits its eggs in the cuticle of the leaf, and these in due course give birth to yellowish-white larva. The latter pupate in the
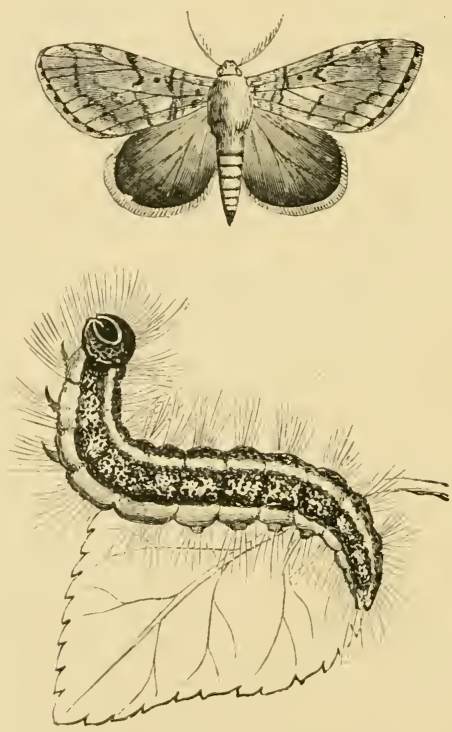

GLPS MOTH (LPARIS DISPAR).

leaf, remain there till spring, then emerge as flies to again lay eggs.

Remenies.-Gather and burn all fallen leaves, and pick off any that are badly mined and serve likewise. In May and June spray the trees with Formula 14 or 27, to render the foliage distasteful to the flies. 
Larch Aphis (Chermes laricis).-This pest occasionaliy does a great deal of harm in larch plantations by infesting the shoots and foilage, and sucking out the sap. The female lays her eggs in April or early in May at the base of the leaf-stalks, at the rate of about five a day, and

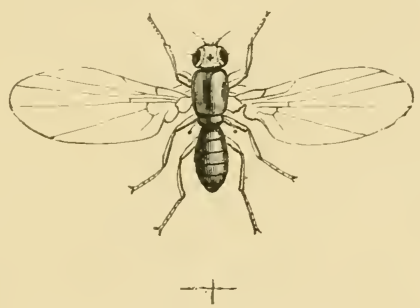

outo
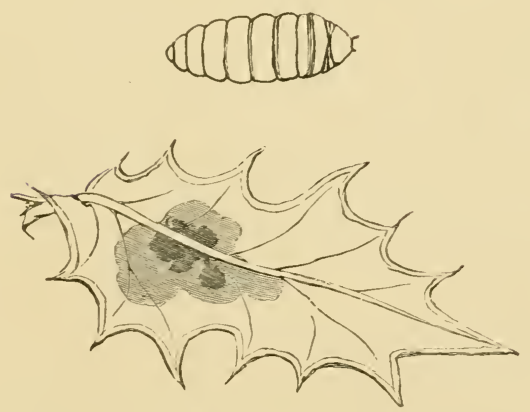

HOLLY LEAF MINER FLY AND LARTA.

The cross lines indicate the natural size of the leaf. Below, the larva is shown of natural size and magnified. The blotch on leaf ehows injury done by the larva.

these are covered by a woolly substance secreted by the mother. From these hatch small blackish or violet larva, which afterwards change to a pale olive-green. Successive generations are produced from eggs up to autumn, then a mother Chermes survives to lay eggs the following 
spring. They are all covered with a powdery or cottony secretion.

Renedies. - Spraying with a Soap and Quassia (No. 14) or a Kerosene Emulsion (No. 16) seems to be the most effective remedy. Where the trees are small, dusting with powdery lime has proved efficacious.

Large Larch Sawfly (Nematus Erichsoni).-The larve of this sawfly has wrought considerable injury among the larch forests on the Continent, and in 1906 they were found in immense numbers in larch plantations in Cumberland. In this case they entirely defoliated most of the trees. The parent sawfly is about $\frac{3}{8} \mathrm{in}$. in length, has glossy wings and a dark body. The fullygrown larva is about $\frac{3}{4} \mathrm{in}$. in length, has a black, hairy head, greyish-green body on top, and yellowish-green beneath. The " eggs are laid in one or two rows on the roungest larch shoots, and in slits in the bark made by the saws of the females." The larve winter in cocoons, pupate about May, and appear as sawtlies in June. The feeding period is from Jume to September.

Anyone finding caterpillars feeding on larch should forward specimens to the Board of Agriculture inspector at once, in compliance with the terms of the Order published oll p. 314.

Nun or Black Arches Moth (Liparis monicha). - A near relative of the Gipsy Moth. The fore wings of this moth are white patterned with black; the hind ones are greyish, and the abdomen of a red tint. The larva, which appear from April to July, are yellowish-creamy white, marblerl with black. 'There are four tubercles on each segment, earch having a tuft of hair. The head is large and spereled. A voracious pest, feeting on the apple, oak, and other forest trees with great avidity and inflicting serious injury in some seasons. Both species should be reported, as advised in Chapter V., when discovered. 
Oak-leaf Roller Moth (Tortrix viridana).-This moth is the parent of caterpillars which in some seasons do an immense deal of mischief to the foliage of oak trees. The moth is snull in size, has light green fore and silverygrey hind wings. It appears in June, lays its eggs on the leaf buds during the summer, and these hatch out the following spring. The caterpillars are half an inch long, greenish-grey, and have the habit of rolling the leaves round so as to form a cylinder or tube, in which

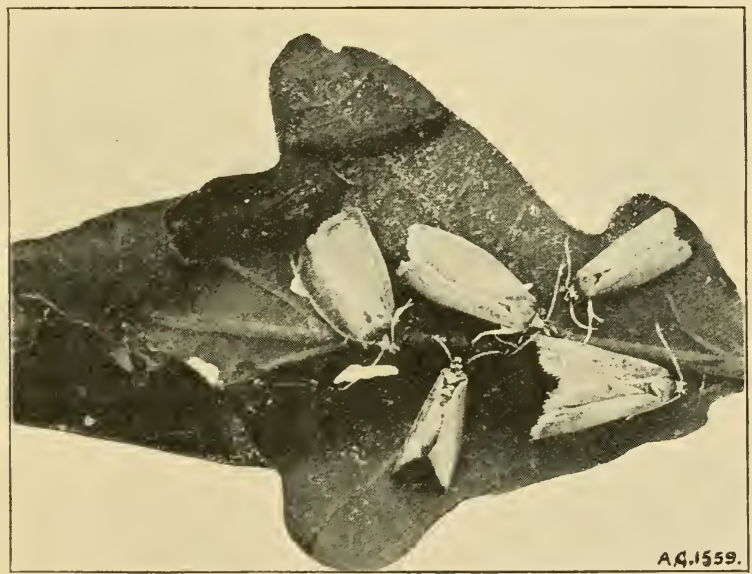

[Photo: J. G. Blakey.

OAK ROLLER MOTH, LARTE AND PUPA. them.

A destructive lest, the larve of which roll the leaves together and devour

they feed and remain till they are full grown, then let themselves down to the earth to pupate by a thread.

Rexndes.-Thoroughly drenching the trees with a Soap and Quassia (No. 14), Kerosene (No. 16), or Paris Green (No. 11) preparation, is the only effectual remedy.

Pine Beetle (Hylurgus piniperda).-This beetle is about half an inch long and of a pitchy colour. It makes 
its appearance in April or May, bores holes in the bark of dearl, discased, or living pine trees, forms a tmmel, and deposits her eggs therein. When the larve are hatched they, too, form transverse tunnels on both sides of the main one. In due course they pupate, and emerge as beetles in August. These new beetles fly off to the nearest pine tree, settle on the young shoots, and bore into and up through them, causing the shoots to die.

Remedies. - (1) Allow no fallen trees to remain in pine woods. (2) Cut down and remove all sickly trees. In the case of young shoots attacked, remove and burn these.

Pine-bud Tortrix Moth (Orthotienia [Retinia] turionana). - This is a small moth of a rusty-red and silvery colour, which is the parent of a reddish or purplish-brown caterpillar, half an inch long, that feeds on or inside the growth buds of the pine and fir. The moths lay their eggs in July, and the caterpillars appear in twelve days. By eating the buds they destroy the future branching and leading shoots, and spoil the after-growth of the irees. The Pine-shoot Tortrix Moth (Retinia buoliana) also inflicts similar injuries upon pine and fir trees.

Remedies. - The only remedy appears to be to examine the shoots and remove the caterpillars. Spraying with a Quassia (No. 14) or Paris Green (No. 11) preparation might be tried if the pests are very numerous.

Pine Sawry (Iophyrus pinii).-Considerable harm is often klone to pine and fir trees by the larvae of the above Sawtly. The latter makes a slit in the leaf by means of her ovipositor, leposits several eggs therein, and then covers these with a glutinous substance. The caterpillars, which are pale green, with a rusty-brown head, black jaws, and marked with black spots on the sides, hatch in about three weeks. They are voracious feeders, devouring rapidly the leaves and the bark of the young shoots. If very numerous they soon do incalculable damage to the trees. 
Remedies. - (1) Pick off the caterpillars by hand. Spread sheets under the trees, and well shake the latter to cause the caterpillars to fall. (3) Gather and burn all loose material around the trees in autumn.

Pine Weevil (Hylobius abietis). - This is a weevil about half an inch long, and of a dull blackish colour. The females lay their eggs in crevices of the bark, and the larva therefrom hatch out in about three weeks. The latter are legless, fleshy, white, and about half an inch long. They form tunnels in the soft part of the bark,

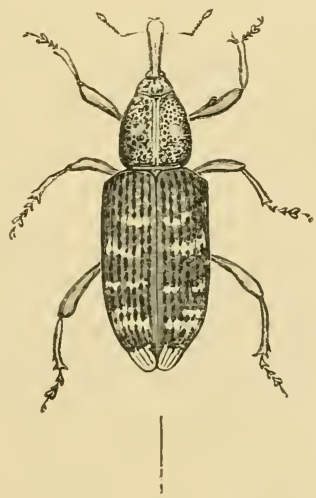

CONIFER BEETLE (HYLOBIT'S ABIETIS).

The vertical line at base shor 6 the natural length of the beetle.

pupate in autumn, and emerge as weevils the following June. The weevils feed on the bark of the young shoots of pines, firs, spruce, and larch.

Remedes.-(1) Clear away all old stumps or roots of coniferous trees from healthy plantations, so as to afford no harbour for the weevils. (2) Place sheets under the branches, and well shake the trees to cause the weerils to fall; then collect and burn them.

Puss Moth (Dicranura vinula). - The moths have white and grey wings, marbled with black, and the whole 
body is covered with soft down. They lay their eggs in June on the leaves of poplars and willows, and in due course caterpillars appear, which are easily recognised by their peculiar shape. At the extremity of the body are two horn-like projections, and the colour is a purplishbrown, striped with white. The larve feed on the leaves, and when fully matured they gnaw away a portion of a shoot and glue the débris together to form a cocoon, in which they change to a chrysalis, and emerge as moths in the following June.

Revenes.-Hand-picking, or spraying with Formula Nos. 10,11 , or 12 .

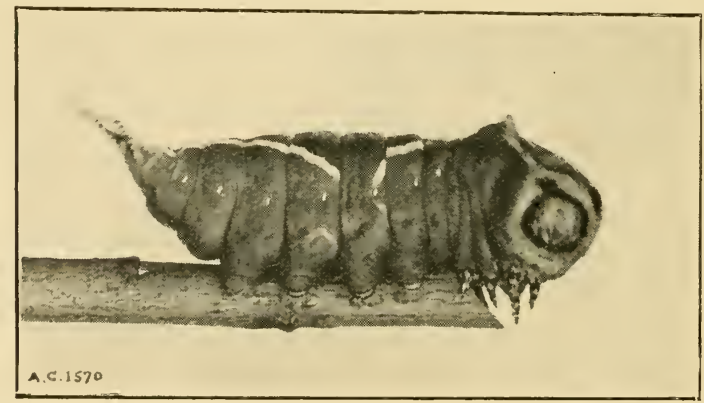

[Pioto: J. G. Blakey.

LARVA OF PUSS MOTH (DICRANULA VINULA).

Spruce-gall Aphis (Chermes abietis).-This aphis infests the young shoots of the spruce fir, causing galls or protuberances to form, and checking the proper development of growth. As in the case of the Larch Iphis, so in this, there is a mother Chermes which survives the winter, and lays from one to two humbled ergs in May on the shoots. These eggrs give birth to larve, which at once pierce the tissues with their suckers and feed on the sap. The irritation thus produced causes galls to form, under the protection of which the larvie thrive. The 
larve in due course pupate, and then emerge from the galls as winged females or wingless males, and a second batch of eggs is laid.

Remedies.-Cutting off and burning the galls in summer is the only remedy.

Willow Beetle (Phratora vitellinex).-This beetle
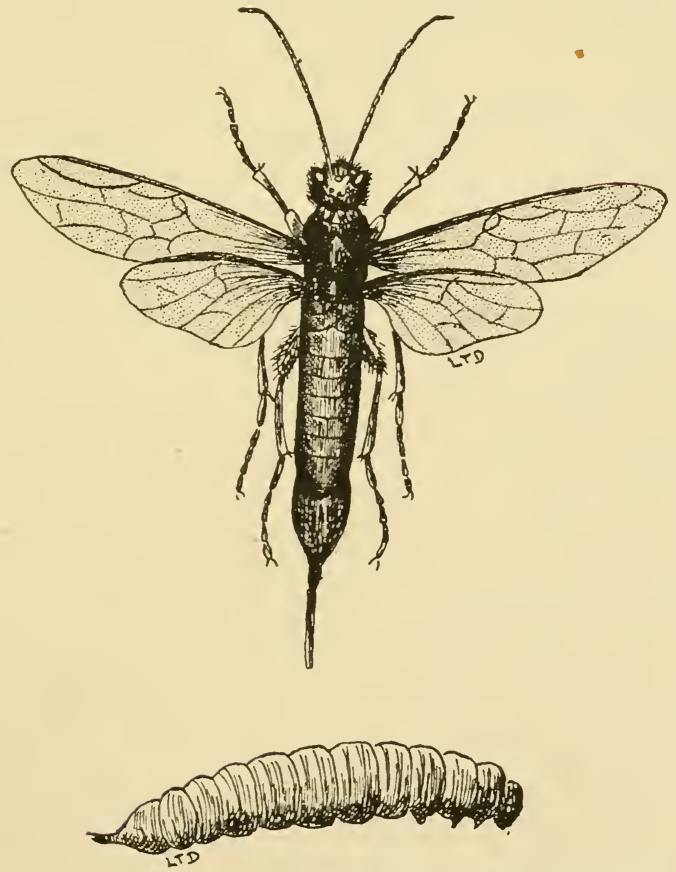

GIANT SIREX OR WOOD WASP (SIREX GIGAS).

(Both natural size.)

feeds on the leaves of willows and poplars, eating holes therein. It is about one-sixth of an inch long, bronzygreen in colour, and more or less oval in shape. Eggs are laid in patches invariably on the under sides of the 
leaves, and these give birth to larvie half an inch long and yellowish or whitish in colour, and marked or spotted with black on the back and sides. The larva feed on the under sides of the leaves. In some seasons this pest does considerable, harm to willow plantations.

Remedes.-Spraying with Paris Green (No. 11) or a Kerosene Emulsion (No. 16) in summer, is the only method of eradicating this pest.

Wood Wasp, or Sirex.-Two species of Silex do damage to coniferous trees, such as larch, pine, etc. The Giant Sirex ( $\mathrm{S}$. gigas) is a wasp-like insect, black, banded with yellow, and with black thighs, yellow feet, and brownish-yellow membraneous wings. The other species, the Steel Blue or Common Sirex (S. juvenicus), is blueblack in colour, and has reddish or bluish feet. Both lay their eggs in the bark, and in due course whitish cylindrical maggots are hatched, which bore into the trunks of the trees, and do great damage.

Remedies. - Clear away dead or diseased trees, so that the females cannot find a ready means of depositing their eggs. Fortunately, these pests are not numerous.

A number of larve of moths feed on the leaves of trees, but their injuries, as a rule, are not very serious.

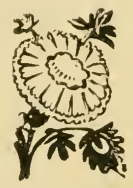




\section{CHAPTER II.}

\section{DISEASES OF FOREST TREES.}

Euonymus Mildew (Oidium euonymi-japonica).The euonymus is occasionally attacked by a fungus which develops in white patches on the leaves and shoots. In a few cases we have seen the whole plant attacked. If allowed to increase, it seriously cripples the growth of the plant.

Remenies.-(1) Collect all diseased shoots and leaves and burn them. (2) Dust the bushes, when damp, with flowers of sulphur. (3) Spray with Sulphicle of Potassium Solution.

Larch Canker Disease (Dascypha calycina).Many plantations of larch have been badly injured by this fungus. It appears to attack trees growing in damp situations and where they are much crowded together. The disease gains access to the trees through the medium of punctures or wounds. The mycelium develops under the bark, causes a resinous exudation to form, and the ultimate death of the bark in the region of infection.

Remedies. - Where badly attacked the best plan is to cut down and burn the trees. Where only slightly attacked, pare away all the diseased parts, then wash with a solution of sulphate of iron and paint with Stockholm tar.

Sycamore Leaf Blotch (Rhytisma acerinum).The leaves of the sycamore and maple are often disfigured in late summer by black blotches. These first appear of a yellow tint, and then turn quite black. The presence of this fungus on the leaves seriously interferes with their 
natural functions, and it should therefore be prevented from spreading to healthy foliage.

liemedies.-Gather and burn all the fallen leaves in autumn, before the spores have time to ripen and liberate themselves.

Witches' Brooms.- I popular name for the bundles or bunches of twiggy, mistletoe-like growths often seen on the silver birch tree. These peculiar growths are formed in the first instance by a fungus called Exoascus turgidus. The fungus first attacks the leaf and then permeates the tissues of the shoot. Each year, as new shoots are developed from the first one, the fungus spreads, so that in time quite a tangled nest-like bunch of twigs is produced. A similar growth appears on cherry trees.

Reveny.--Cut away the mass of growth entirely.

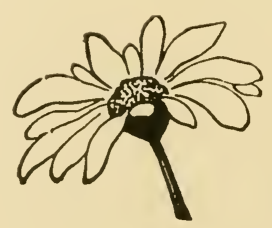




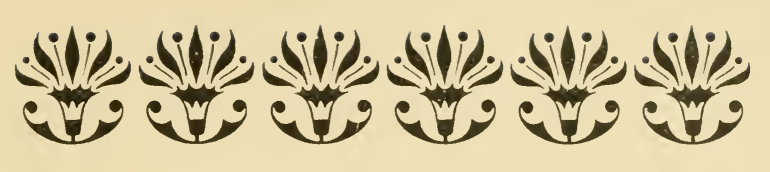

\title{
Part VII._ODDS AND ENDS.
}

\author{
CHAPTER I.
}

\section{MISCELLANEOUS PESTS.}

Ix this chapter we propose to deal briefly with a few pests and otherwise that could not be included in previous sections.

Birds. - Unfortunately, a good deal of ignorance prevails among gardeners as to the real character of bird life in relation to the garden. Because a blackbird or a thrush steals a few cherries or strawberries, a house sparrow mischievously nips off the blooms of crocuses or the leaves of carnations in spring, a chaffinch or a greenfinch purloins a few seeds, or a bullfinch or titmouse vigorously pulls off the fruit buds of gooseberries, etc., in winter, it is at once assumed that these birds are enemies and must be forthwith decimated. Such a notion is a most erroneous one. Birds are friends rather than enemies of the gardener, and should be protected, not destroyed. Blackbirds and thrushes feed on slugs and snails; titmice and bullfinches on eggs or insects secreted in the buds; the chaffinch and the greenfinch on weeds and caterpillars; the starling on worms, leather jackets, 
and grubs generally; and the house sparrow on grubs and other insects. Surely, if these birds render us such excellent service in decimating the chief pests that attack our crops, we ought not to begrudge them levying a toll on a few fruits as a reward for their services. Is it not wiser on our part to encourage the presence of birds in our gardens, and to protect such crops as are likely to be injured by them?

Renenies.- Kipening fruit can easily be protected by a covering of old fish-netting placed over the plants or trees. The buils of gooseberries may also be protected by spray-

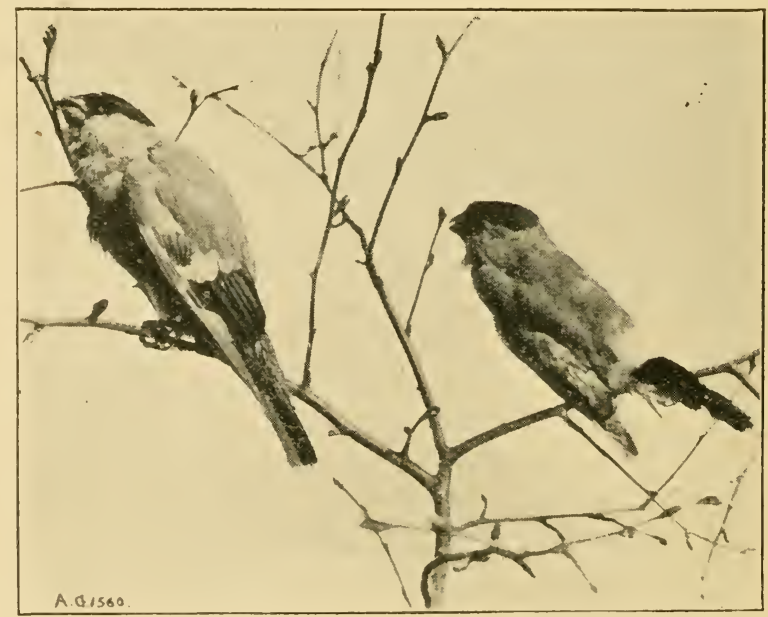

[Photo: J. G. Blakey.

BULLFINCHES EATING FlRIT BUDS.

ing the trees in winter with the lime, sulphur, and salt wash (Formula No. 5). This will serve the double purpose of rendering the buds distasteful and kill insects as well. It is well, too, to defer the pruning till late in the winter; then the birds can only get at the outer buds. To prevent birds eating seeds, put the latter in a 
saucer or dish, moisten very slightly, then sprinkle powdered red lead over them, and well stir till the seeds are properly coated. Sprearl the seeds out to dry, then sow them. A small quantity of paraffin oil sprinkled over the seeds before sowing will be equally efficacious. Rows of peas may be protected by means of pea guards, or by bending sticks over and plaring fish-netting thereon. Strands of black cotton stretched over seed beds will frighten away birds from crocuses and carnations, and distings of soot and lime render the leaves distasteful.

Cats. - We shall, doubtless, involie the wrath of some of our cat-loving readers by having the audacity to include Felix domesticus in a book on garden pests. There can be no question, however, that, while there are wellbred and well-cared-for cats who do no harm to gardens, yet, on the other hand, there are, unmistakably, others that do unlimited mischief in scratching up seeds of plants, and damaging plants by fighting and squabbling among them. We feel, therefore, that we must give a hint or two how to prevent the latter doing injury, but in doing so we shall certainly not offend owners of well-behaved pussies by giving suggestions for maiming, killing, or torturing them. We are far too fond of cats ourselves to do anything that would suggest injury or cruelty to them. $\mathrm{We}$ may here make a passing reference to the legal aspect of the cat in relation to the garden. It is a criminal offence, punishable by fine or imprisomment, to lay down poison for, or to shoot, or to trap cats. A cat is recognised by the law as a domestic animal, and therefore comes under its protection.

Remedies.-(1) The owner of a garden is not bound to fence his garden round with wire or with netting, or anything else, to prevent animals from trespassing upon his property. It is a neighbour's duty to prevent his cat from straying and doing damage. Write at once to your neighbour and tell him that if the cat does further damage you will immediately bring an action for damages in the 
County Count; and, at the same time, say that you will lirep the cat when next fomm upon your premises, ame dotain it motil he pays you a reasomable sum to compensate you for the dimage it has oceasioned. (2) It, however, you feel disposed to lieep rats out of your garden, you car adopt one of the following comses: (a) Wirenetting (1ft. wide) may be fixed at right angles on top of the fence or wall to form an almost unfailing barrier to these enemies of the town gardener. If the fence is anything above 5ft. all that is needed will be pieces of wool mailed to each main post, so as to overhang the garden, and the wire-netting laid on these, and rery securely fas-

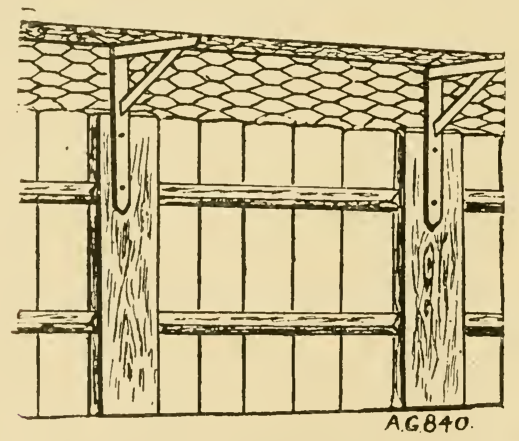

Fig. 1.-A WIRE NETTING C.IT EXCLUDE?.

tened by wire staples where it joins the fence. Should the fence be a low one, pieces of woor in the form of a gibbet must be nailed on and wire-netting fixed to heighten fence to 5ft., and then either bent over at right angles, or a separate piece $1 \mathrm{ft}$. wide can be laced to it by means of galvanised wire. Should a very persistent tabby leap from this into a garden, it is impossible for it to get back again, and it can be chastised before being allowed to return. (Sce Fig. 1). (b) A reader of "Amateur Gardening" says: "My remedy is the novel one of being not only the best, but at the same time the cheapest. I 
have personally tried it, and have watched results on my neighbour's' fences, and can say that in every case it has been effective. I enclose a rough sketch showing method of fixing. The wire is small-gauge galvanised, and sold

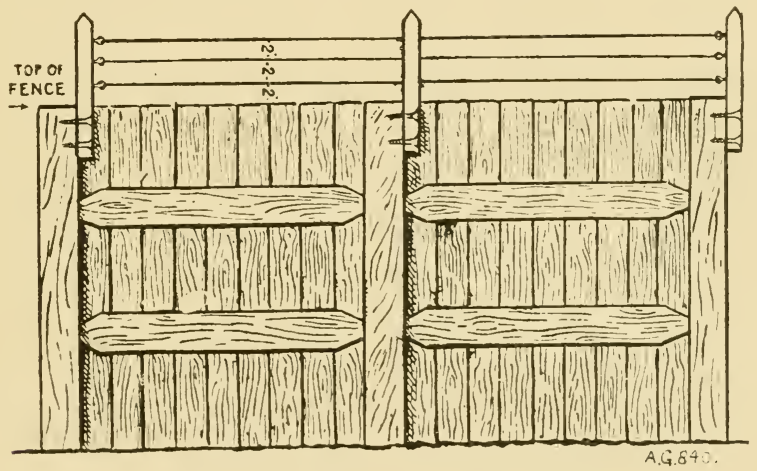

FIG. 2.-A WIRE CAT EXCLTDER,

for td. per pound. The wood required is one piece for each post of your garden fence, and is $1 \mathrm{tin}$. long by $1 \frac{1}{2} \mathrm{in}$. square, and is fixed on posts by two screws, and is left

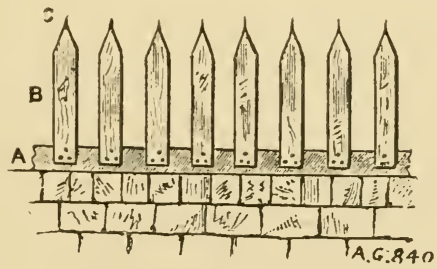

FIG. 3.- I APIKE PALING C.IT EXCLIDER.

projecting above funce eight inches. Three strands of wire are then stretched tight the whole length of the fence, and exactly over the boards, or palings, the wire should go through all the uprights by a small hole except the two 
outside ones, which can be fixed by screw-eyes as shown. The cat, to scale a fence topped with wire, has to come in contact with it, and cats utterly detest small wire." (Wee Fig. "2). I third methor (Fig. 3) is to fix some short palings to the top of the wall. In the point of each pale fix a pointed French wire nail.

Hares and Rabbits. 13oth ro injury to carnations, regetable crops, and the stems of trees in gardens, by gllawing off their bark.

Remenes.-(1) The best preventive measure is to fence the garden in with wire-netting. Failing this, surround the carnations with wire-netting, and paint the stems of trees likely to be attacked with a mixture of train oil, cart grease, and soot to a height of $3 \mathrm{ft}$. from the ground. Inother good remedy is to make a paint of fresh cowdung, clay, and water, and to each pail add a teaspoonful of tincture of asafotida. Paint the bark with this. In the case of trees that have been partly barked by rabbits or hares, smear on a thick plaster of cow dung, clay, and soot, to help the wounds to heal.

Mice.-Two kinds of mice are troublesome to garden crops. The Common or House Mouse (Mus musculus) feeds upon seeds, grapes, and other crops, indoors and outdoors. The Long-tailed Field Mouse (Mus sylvaticus) also feeds upon bulbs, tubers, corms, newly-sown seeds, and even the roots of carnations, etc. Then there is also the Field Mouse, or Vole (Arvicola arvalis), a short, tuftedtailed, blackish mouse, which lives in fields and also gardens, eating the roots of plants; and the Bank Vole (Arvicola riparia), also short-tailed and chestnut-coloured, which lives in riverside banks, ete., and feerls on plants.

Remenies. - The best remedy for indoor mice is a keen female eat. Other remedies are trapping or using one of the well-known rat poisons. To protect newly-sown pea and bean seeds, adk two ounces of aloes to a gallon of water, and soak the seeds for twenty hours in this before 
sowing. Or, mix a tablespoonful of paraffin oil with one quart of seeds, and sow them whilst wet. Seeds, bulbs, and corms placed in water for a short time, then rolled in powdered red lead, will be immune from the attacks of mice. The old "Figure of 4 " trap is a simple and effective way of catching mice in the garden. Bait with a piece of toasted cheese, or, better still, with nut kernels. The trap is casily made and put up. If a few of these are always liept baited with toasted cheese they are sure to attract any mice within a short distance of the place.

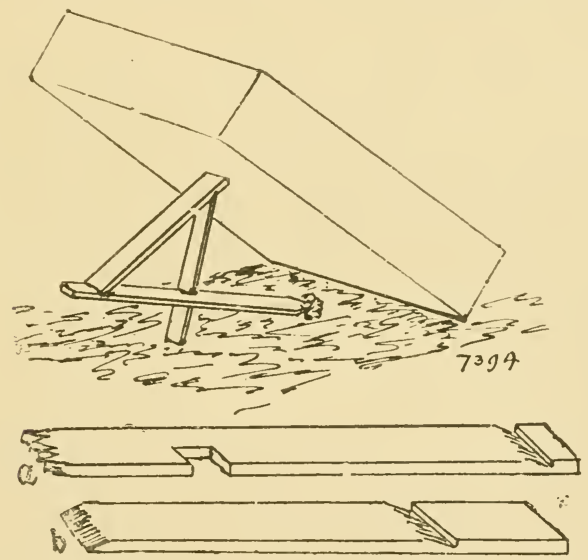

FIGURE OF 4 MOLSE TRIP.

It is made as follows: Take a common lath and split it kown the centre; then cut an upright piece about 4 in. long, the top of which should be made wedge-shape, and the bottom quite flat. Another piece should be made. This should be wedge-shaped at the lower end, and have a notch cut in at the other, to fit on the upright (see B). A third piece, made longer than the others, and extending two or three inches beyond the perpendicular one, should next be made (see A). On the end of this the bait should be tied. The front end has a notch cut in to receive the 
redge of the slanting piece, and another is cut on the side so as to take the upright. I slate or tile shoukl be laid on the ground, and near one end the upright piece be stoor. Bring the slanting one next in position, the end with the cut mate in it being placed on the top of the other, the lower end of which is made to fit into the horizontal one. The rreight of the slate or tile resting on the upper end of the slanting piece will hold them in position until something pulls at the bait, when the whole falls down together.

Moles (Talpa europiea).-Although one naturally feels a certain amount of regard for these "relvet-coated denizens of the soil," because of the service they renter in derouring harmful Wireworms, Grubs, and Slugs, to say rothing of Earthworms, ret one camnot ignore the fact that they do a great deal of damage to our lawns and our flower gardens by their active tumnellings beneath the surface. Since we have no means of keeping them out of cur garlens, and they will renture therein mbidden, we must, ont of regard for our plants and our lawns, adopt means of capturing them in order to avert further damage.

Remedes. - The best way of capturing moles is by means of the recogniserl iron mole-trap--set in every " run," and not in a "mole-hill." Find out the rums, open the earth with a spade, and then set the trap across the rm and cover with soil. Use gloves on the hands when handling the trap, as moles have an acute sense of smell, and would aroid entering it. Moles may be poisoned in the following manner: Collect half a pint of earthworms, get a chemist to ardd a rlrachm of strychnine to them; stir well for a ferr momonts; then open holes here and there in the rums, drop) in a few worms, and covere with soil. An rexeedlent plan for those who keep retrierer or fox terrier dogse, is to train them to wateh for moles at work, indiraterl by the heaving of the soil, and then set the dogs (1) to catch them. I smart dog will pounce on a mole at once, and bring it out in a moment. 
Rats (Nus decumanus). - The Common or Bromn Riat is a mischievous creature either indon's or outdons, feerling on seeds, fruit, or roots, and should be promptly ex. terminated.

Remabres.-(1) The quickest and easiest ways of exterminating rats is to ferret them out. (2) Where this cannot be lone, have resort to wire or steel traps. Bait with toasted cheese or bacon, and handle the traps with gloved hands. After the traps are set, sprinkle the following rat scent about the trap: Aniseed, $\frac{1}{4}$ oz.; aquafortis, 3 drops ; musk, $1 \mathrm{gr}$. Mix the musk and the aniseed well together before adding the aquafortis. This scent will attract the rats rearlily to their doom. (3) Find out their runs, and block them up with broken glass and cement. (4) Rat poisons. These, however, should only be used where there are no children, pets, or poultry.

\section{CHAPTER II.}

\section{WEEDS ON PATHS, ETC.}

Paths and drives formed of gravel, stone, or ballast, are bound sooner or later to become infested with weeds. The reason is that the material contains a certain proportion of earthy matter capable of supporting regetable growth; and, as there are no means of preventing weed seeds being conreyed by the agency of winds, birds, etc., these will germinate, and render measures being periodically adopted for their destruction. Of course, there is no possibility of this trouble arising in the case of tar, asphalte, and concrete paths. Fortunately, we have at our disposal an effectual means in the shape of powerful liquid weedicides, capable of killing weeds wholesale, and thus there 
is not the necessity, as in days of old, of going through the tedious and expensive process of weeding by hand.

Weeds Infesting Paths and Drives.-The chief weeds infesting gravel and ballast paths, etc., are various kinds of grass. The seeds of these are blown from neighbouring pastures, or from neglected corners of the garden where grasses are permitted to flower and bear seeds. Birds, too, often carry them on to the paths. The moisture in the interstices of the gravel afford the seeds just the ideal conditions for germination and subsequent growth, and it will be observed that many grasses possess the precocious habit of reaching maturity rapidly and coming into flower. If one tuft of grass only be permitted to flower and bear seeds, these will in time speedily produce a crop of seedlings, and take possession of considerable areas of path. Then again, moss is a very troublesome weed, growing freely in damp situations or under the shade of trees. Lichens, too, grow freely in badly-drained paths. Both these weeds grow in dense patches, and are difficult to eradicate by hand. Another troublesome path weed is the Knotweed (Polygonum aviculare). This has slender wiry stems, which spread closely on the surface, and strong, deeply-descending roots which render the weed difficult to extract. The Pearlworts (Sagina), Spergulas, Daisies, Plantains, Dandelions, and Bindweed are further examples of weeds that infest paths and drives, and give immense trouble to get rid of once they obtain a good foothold.

Weed-killers, or Weedicides.-There are several special liquid preparations sold by dealers in horticultural sundries and by chemists that, when diluted with water and applied by means of a fine-rosed water-pot to the surface in sufficient quantity to saturate the gravel, will speedily kill every kind of weed, and at the same time so poison the earthy portion of the path or drive as to prevent seeds germinating or weeds growing therein for a long time. Those who make a practice of applying one 
of these weedicides annually are rarely troubled with weeds, and the preparation has the property also of cleaning the gravel, and imparting to it a fresh, clean appearance. It would be invidious on our part to mention the names of these preparations. Suffice it to say, they are known by the general name of "weed-killers," or "weedicides," and the sources of their supply may be obtained by consulting the adrertisement pages of the "Gardeners' Magazine" and "Amateur Gardening." They may appear costly preparations to use, but, when it is remembered that one application a year will eradicate the weeds and help to keep the surface free from future growths for that period, they are not really expensive in proportion to their effectiveness and easiness of application.

Home-made Weed-killers.-Those who prefer to try home-made preparations or simple remedies, may use one of the following:

(1) Salt Brine.-This is a comparatively inexpensive remedy. Dissolve 1lb. of salt in each gallon of boiling water, and apply in a hot state by means of a fine-rosed water-pot to the surface of the path in dry weather. Apply sufficient to saturate the surface and reach the roots of the weeds.

(2) SALT.-Where there are only a few weeds to get rid of, sprinkle a little salt over them in dry weather. The disadvantage of salt and brine is that in the course the salt undergoes a chemical change, and slightly enriches the earthy matter, thus providing richer food for supporting a fresh crop of weeds.

(3) Carbolic Acin.-Add one fluid ounce of carbolic acid to each gallon of water used, and apply by means of a fine-rosed water-pot. Use leather gloves to protect the hands from injury by the acid. An efficacious remedy, which prevents the growth of future weeds for a long time after use. Apply on a hot day. Poisonous.

(4) Sulphuric Acid. - Add 1lb. of sulphuric acid (oil of 
vitriol) to ten quarts of water. Mix slowly in a wooden tub, then apply with a fine-rosed water-pot well painted inside. Apply on a hot day, and use leather gloves to protect the hands. Do not leave the fluid standing in the pot, otherwise it will destroy the metal. Soak the pot in water after using. Poisonous. Do not walk on path for trenty-four hours.

(5) Hrorochlonic Acm. - Use at the rate of half a pint to a gallon of water, and apply as adrised for No. 4, observing similar precautions in regard to mixing and protecting the hands. Poisonous.

(6) Irsendte of SonA.-Add 1lb. of powdered arsenic to three gallons of cold water, and boil and stir thithoroughly for a short time. Next add seven more gallons of water and 2lb. of crushed soda; keep boiling and well stirred till the latter is dissolved. Apply, whilst hot. with a fine-rosed water-pot, in dry weather. A highly poisonous liquid. Keep from animals and children.

(7) GAs-Jipuor.-This, if applied in an undiluted state, will effectually kill weerls and moss on gravel or ballast paths. Apply in dry weather.

(8) Lime Axin Sulphur. - Boil 20lb, of quicklime and 2lb. of flowers of sulphur in 10 gallons of water for half an hour in an iron pot. Allow the serliment to settle, then decant off the clear liquor, and apply this to the paths.

Special Precautions.-Before using any of the foregoing remerlies, carefully read the following remarks:

liemember that all acids are more or less caustic, and will burn the flesh or clothing if either come in contact with each other. They are, moreover, destructive to grass, box, or other living edgings, and therefore must on no account be allowed to touch them. We strongly advise the rearder to use two piesess of board, placing one (n) each side of the path, to protect the edgings whilst the liquiels are being applied.

Another important point to remember is that what will kill the weeds on a path will also destroy turf and box 
edgings; so on no account apply the liquids too close to the margins.

Yet another point of special inmportance is to apply the liquids in dry weather, so that they soak in, destroy the weeds, and lose their destructive properties before rain falls, and causes the acids, etc., to be washed to the roots of box or of turf.

All the materials being more or less poisonous, great care should be exercised in their use, and in placing any surplus liquor safely under lock and key.

Acids, too, should be slowly mixed with water-not the water added to the acid-and preferably in wooden vessels.

\section{CHAPTER III.}

\section{LAWN WEEDS.}

A short chapter on lawn weeds will certainly not be out of place in this work. They are in every sense a pest, and a troublesome one, too, causing much concern to those who desire to get a perfectly good turf.

The Principal Weeds that infest lawns are the Daisy, Dandelion, Plantain, Crowfoot, Dock, Self-heal, Sorrel, Mouse-ear, Chickweed, Bird's-Foot, Trefoil, Clover, Yarrow, Fairy-ring Fungus, Thistle, Pearlwort, Hawkweed, Knotgrass, and Moss. Our space will not permit of a detailed description of each. For this information see our shilling handbook on "Lawns and Greens."

Pemedies.-A wholesale way of getting rid of these weeds is dressing the infested patches in spring with a well-known preparation called "lawn sand." If this be sprinkled over the surface at the rate of $40 z$. per square 
yard, at intervals of a month during April, May, and June, the weeds may be got rid of.

Another, but a more teclious, yet thorough, way of eradicating weeds from a lawn is by spudding them out. This may be done by means of a special tool called a weedextractor, or by kneeling on a linee-pad and digging each weed out by the aid of a steel table fork. In this case it is advisable to divide the lawn into widths of a yard by means of a garden line, so that the work can be done evenly and thoroughly. Once thoroughly done, it will be an easy matter to keep the weeds in subjection in future.

A good way of killing Dandelions, Plantains, Thistles, and Docks with deep roots is to dip a stout iron sliewer in a phial of sulphuric acid, and thrust this well into the heart of each plant., Use leather gloves for doing this in order to protect the hands from the corrosive acid. Florists and sundriesmen sell a special syringe for doing this.

A little salt placed over the crowns of weeds, but not on the grass, in dry weather, will kill them, and is a simple remedy.

To get rid of clover, if objectionable, apply half an ounce of nitrate of soda or sulphate of ammonia to eash square yard of clover patch in spring. The nitrogen will sicken the growth of the clover and promote the development of the grass.

To kill the Fairy-ring Fungus, dissolve 1lb. of sulphate of iron in two gallons of water, and well saturate the turf to a width of $3 \mathrm{ft}$. outside the dark ring.

Other Lawn Pests are Ants, Worms, Leathel Jacket Grubs, and Moles, remedies for which are given elsewhere.

\section{$\oint \oint \oint$}




\section{CHAPTER IV.}

\section{A FEW FRIENDS.}

Since we have described the enemies of crops, it is only just that we should also draw the grower's attention to a few of the friendly insects and animals that may occasionally, if not frequently, be seen in the garden, in order that they may be spared to help him in reducing the number of the former. It would be wrong to treat every living creature found on plants or in the garden as a foe. One must learn to discriminate between the two, so as to spare those which render the gardener a lasting service in reducing the pests that conspire to do so much injury to his plants.

Birds.-See our remarks on this subject in Chapter I. in this section.

Centipedes.-First of all, there are the Centipedes. The most familiar of these is Lithobius forcipatus, an active, agile little creature, with a shining, horny, ochreous-coloured body, and fifteen pairs of bristly, spiny legs and a couple of longish horns. It measures about an inch in length, and is furnished with very powerful jaws. This creature may frequently be met with in the drainage of pots and in the garden. As often as not it is regarded as a foe, and killed forthwith. Now the centipede does no harm to plants; it feeds entirely on grubs, worms, and small animals, and is therefore a real friend of the garden. It is easily distinguished from the Millepedes by its shorter body, longer legs, and its greater activity. Spare him Another creature, often seen in company with the Centipede, is Geophilus longicornis. This measures $2 \frac{1}{2}$ to 3 in. 
in length, has a very slender, ochreous-colonred body, furnished with fifty-one to fifty-five pairs of legs. The aninal moves with a waving motion from right to left, and leaves behind a thin line of phosphoric Huid, which can be clearly seen in the rlark. This ereature is one of Nature's scarengers, feeding on decayed roots and seeds, and never at any time does any harm to plants. We have often met with it in the soil and rlrainage of pot plants. sipare him likewise.

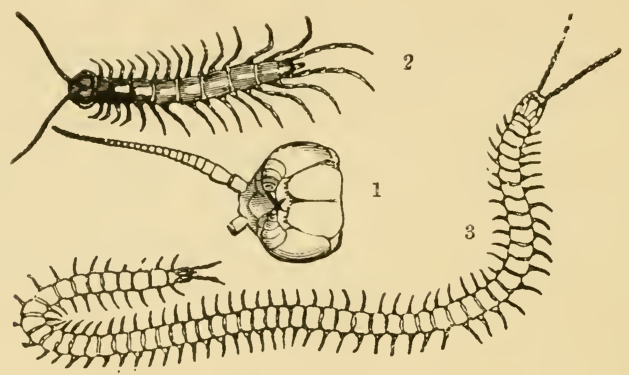

CENTIPEDES.

Fig. 1, Head and antenna of snake Clentipede; Fig. 2 is the Common Centipede (Lithotiue centipatus), and the other (Fig. 3) the Snake Centipede (Geophi. lue longicornis). Both are garden friends, and are published to show the distinction between them and the Millepedes, which are more or less injurious.

Devil's Coach-Horse Beetle (Ocypus olens).This beetle is fairly well known from its habit when interfered with of raising the hinder part of its borly. It has a long, narrow black body, and is of a pugnacious nature, immerliately resenting any interference with it when wandering about the borders and paths. It feeds on soil grubs, and should therefore not be killed when met with.

Frogs and Toads. - These should be encouraged in every garten, as they are really valuable allies. Both feed on slugs, beetles, and grubs, and will devour an inmense number of these pests if unmolested. The 
Common Frog is scientifically known as Rana temporaria, and the Toad as Bubo vulgaris.

Garden spider (Epeira diademata). - This spider spins large webs over bushes, etc., and is particularly abundant during September. By means of its web it traps small moths and flies, and devours them at leisure. It should not be destroyed, but left unmolested.

Hawk Flies (Scieva). - Three species of Hawk Flies, namely, Screva balteata, S. Pyrastri, and S. Ribesi, are
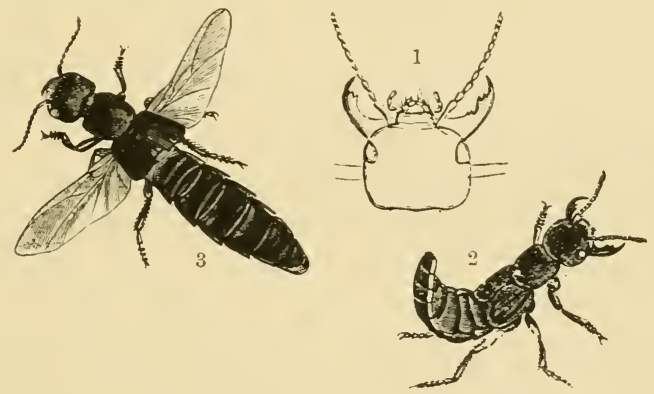

DETIL'S COACH HORSE BEETLE (STIPHTLINUS OLENS).

Fig. 1, Head rith mandibles magnified; Fig. 2, Beetle elevating its posterior when irritated; Fig. 3, Beetle flying.

recognised friends of the gardener. As will be seen by reference to Figs. $a, b$, and $c$, the insects are of a wasplike nature, though they are not capable of stinging. They are exceedingly active, and may be seen darting about here and there in the sunshine with great alacrity. These insects are also called "Horerers," on account of their hovering over the plants. The flies lay their eggs among colonies of Aphides, and when the larve appear these at once begin to feast upon the Aphides. The larvie are so roracious that they will literally destroy hundreds of Aphides in the space of an hour. The larve are whitisis or yellowish-green in colour, narrow at the head, and 
gradually widening at the tail. As soon as they are fully fed they attach theniselves to a leaf, enter into the pupal stage, and finally emerge as perfect flies in a very few lays.

Ichneumon FIy (Pimpla instigator). - There are several kinds of Ichneumon flies, but all are alike in their

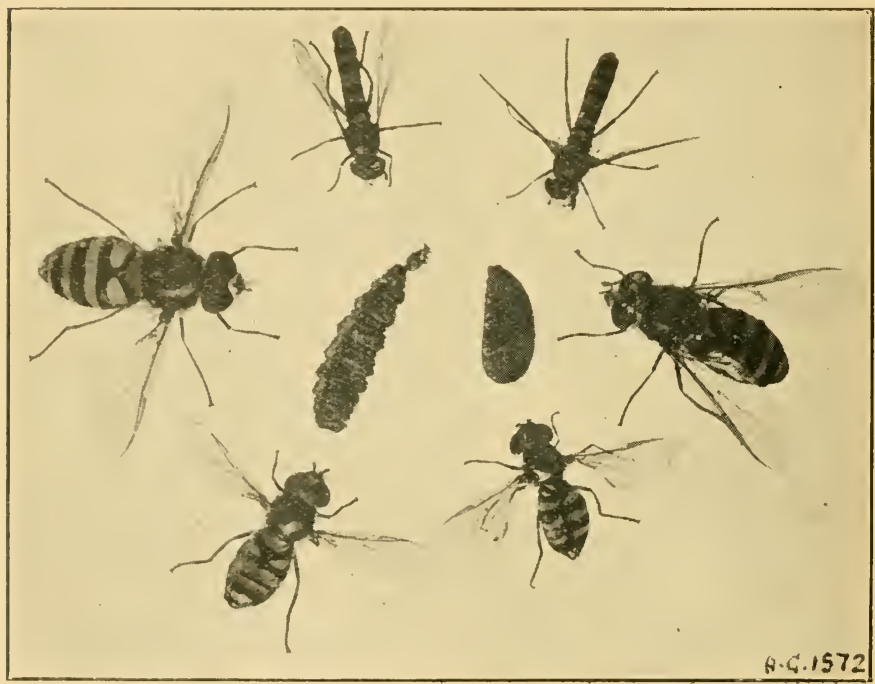

[Photo: J. G. Blakey.

IIOTERING FLIES ANil LARV.L.

creral species of Hovering or Hawk Flies feed upon aplides. In the centre the larra and pupa are shown.

general habits. 'They vary in size from an inch long to that of a midge. All have more or less slender bordies, furnished with an ovipositor similar to the sting in the wasp. These insects alight on the bodies of caterpillars, pierce them with their oripositor, and then deposit an egg, which in due course hatches and produces a grub, that 
feeds on the body of its host. These insects therefore do good in preying upon caterpillars which infest plants generally in the garden. It may be taken as a general rule that all insects which are seen hovering over plants are either Ichneumon flies or Hawk flies, and friends of the gardener worth taking care of.

Lacewing Fly (Chrysola perla).-Doubtless many readers have noticed on their plants in the summer time

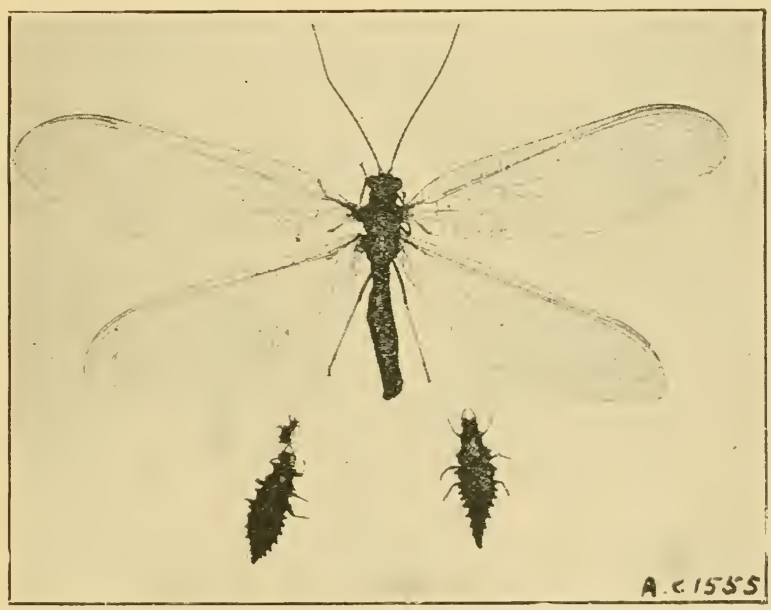

[Photo: J. G. Blakey.

THE LACE-TING FLY WITH LARTE (CHRYSOPA PERLA).

1 pretty insect with gauzelike wings. The two low $r$ insects are the larva, one of which is shown in the act of eating an aphis.

a number of very fine white hairs, with little lnobs at the end, and have come to the conclusion that they were some minute form of fungus. Nothing of the kind. The little filaments are simply appendages with an egg at the end. In a short time the tiny knobs at the ends of the filaments, or eggs, give birth to dirty-white, or pale-brown coloured larvie, marked with brown or orange spots, and with tufts of hair on each side of their body, like the 
example below, $\boldsymbol{\imath}$, which is greatly magnified. The parent insect, $a$, seen nestling on the shoot, has a slender body and pale green, ganze-like wings, with golden eyes. The I acewing fly is really a most beatiful insect, and cammot fail to be recognised when once seen. The larva, which will be easily recognised by reference to $b$, above, is like that of the Hawk tly. The larve are very voracious creatures, and will derour thousands of Greentlies in a remark-

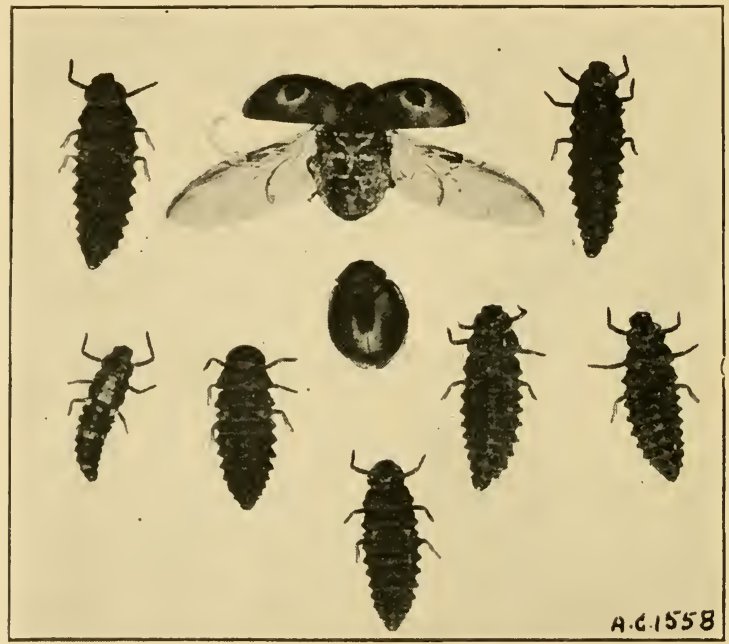

[Photo: J. G. Blakey.

\section{LADY BIRD BEETLES AND THEIR LARV.E.}

One of several epecies of beetles, the larve of which devour aphides. Natural eize.

ably short space of time if not interfered with. Chrysanthemum growers should therefore be careful not to kill the perfect insects, which will be recognised by their golden eyes and gauze-like wings; nor yet to destroy the pretty little thread-like filaments with the eggs perched on the top which may be found on the shoots of plants.

Ladybird Beetles (Coccinella). - W e figure three species of the pretty little Ladybird Beetles. These active 
little creatures, with their scarlet coats and black spots, will be found running freely over chrysanthemums and many other plants during the summer, and, if they are carefully watched, will be observed attacking any hapless Greenfly that may come in their way. The Seven-Spotted Ladybird (see below) is the most commonly met with. All, however, may be easily distinguished by their brilliant colour, and wherever seen they should certainly not be interfered with, as they help to clear plants generally of one of the gardener's worst pests-the Greenfly. Still more useful and still more voracious than the parents are the larvie, commonly known as "Crocodiles" or "Alligators." These creatures are hatched from buff-coloured

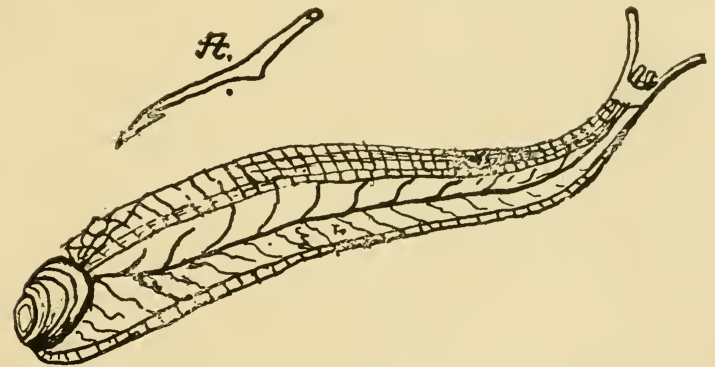

TESTACELLA SLUG (TESTACELLA HALIOTOIDES).

A slug which feeds on worms and soil grube generally.

eggs, which are laid underneath the leaves by the Ladybird Beetles. As soon as the little "Crocodiles" begin to move about they at once derour the Aphides, a single specimen being able to clear off hundreds of these pests in a remarkably short space of time. 'They live for about three weeks in the larral stage, then turn to pupre, and in three weeks emerge as perfect beetles, ready to lay their clusters of buff-coloured eggs underneath the leaves.

Testacella slug.--This belongs to a small family, having but three species, recorded from Britain, Europe, and the Canary Islands. They form a connecting link 
hetwoen what in England are known respectively as slugs and snails, the former being without visible shells, the latter having shells sufficintly capacious for the animal to retire into. In the species under notice the shell is very small, ear-shaped, and situated at the hinder extremity of the creature, and covering the pulmonary cavity. The Testacella slugs are subterranean in their habits, and feest on earthworms, which they follow into their holes, their shells protecting their rear from injury. They feed

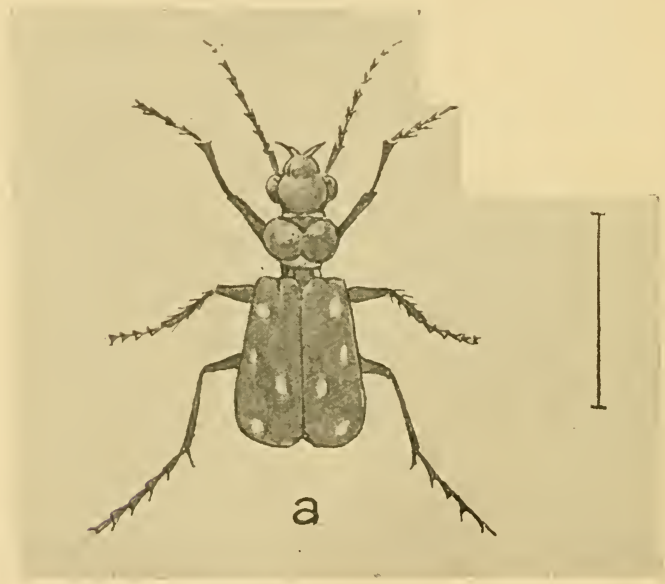

TIGER BEETLE (CICINDELA CAMPESTRIS).

during the day, coming from the holes at night in quest of more prey. When the weather is very dry, and during winter, they form a kind of cocoon in the ground by exuding a mucus from their bodies, and thus rest secure till a change in weather. Unfortmately, these shos are not plentiful in this country, heing almost limiterl to the southern parts of England. T' haliotoides is the lind -most common in this country, and is about three inches long, broadest at the tail end, of a dirty yellow colour, with brown specks; but is sometimes pale yellow or black. 
The shell is about a quarter of an inch long and grerish in colour.

Tiger Beetle (Cicindela campestris).-We figure one of four species of Tiger beetles which are to be met with on all light and sandy soils. These beetles and their larve feed extensively upon all kinds of grubs and small insects. They may be observed running about on the surface of the soil, or flying about from spot to spot in search of food. They should never under any circumstances be interfered with, but allowed to multiply as freely as possible.

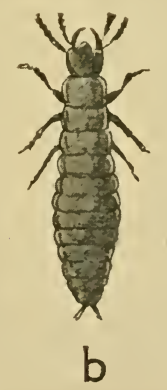

GROUND BEETLE (CARABUS)

$a$, Beetle; $b$, larva.

Violet Grcund Beetle (Carabus violaceus) is an example of a numerous family of beetles that may be found rumning about the surface of the soil in gardens. These beetles and their larve are, like the Devil's Coach-Horse beetle, sworn enemies of grubs, etc., that infest gardens, as they feed to a very great extent upon them. Wherever these active bectles are seen running about, take care that none of them are destroyed, as they help to reduce the number of injurious grubs in the garden. We illustrate one of the species which is common in gardens. 


\section{CHAPTER V.}

\section{BOARD OF AGRICULTURE ORDERS.}

This volume would be incomplete without some reference to the important work which the Board of Agriculture and Fisheries is now doing in the matter of safeguarding our crops from injury by certain pests, some of which are, unfortunately, present in this country, and others which are rampant abroad and might possibly be imported here. This is a step in the right direction. It is a pity the Board did not bestir itself earlier, and so have prerented diseases like the Black Scab, for example, spreading so widely in this country, to the detriment of our potato crops. However, having shown itself sincerely desirous of stamping out the above disease and the American Gooseberry Mildew, we may look forward to its taking every precaution to prevent the importation of the dreaded Sin José Scale, Phylloxera, and other pests which have proved so destructive abroad.

The Board, under the provisions of the Destructive Insects and Pests Acts, 1877 and 1907, now have the power to schedule certain pests already with us and others that have not yet appeared, but which might do if proper precautions were not adopted to prevent their importation, and make special orders with reference to them as occasion requires.

The latest Order is dated 1910, and this contains provisions for the reporting, under a penalty of $£ 10$, of the appearance in any district of the presence of the American Gooseberry Mildew, the Black Scab, or Wart Disease of Potatoes; Nareissus Fly, Brown-tailed Moth Caterpillar's, and the Large Larch Sawfly, pests which have done a considerable amount of mischief to crops in this country. 
The same Orker also refers to other pests which so far have not been discovered doing any damage here, but which would undoubtedly do so if they once obtained a footing in this country. They are the Vine Louse, or Phylloxera, San José ścale, Mediterranean Fruit Fly, Colorado Beetle, Potato, Gipsy, and Nun Moths, Cherry Fly, Gooseberry I3lack Knot Disease, Tomato Leaf Spot, Melon Canker, and the American Pear Blight.

Readers of this volume would do well to carefully study the facts embodied in the recent Order, which we print in extenso below. It is particularly essential that they should do so in the case of the Black Scab Potato Disease and the Amercian Gooseberry Mildew, not only in the interests of themselves, but in that of the crops. The directions given in the Order are very clear, and are as follows:

“Notification of Discovery of Ixsect or Pest.

"1.-(1) The occupier of any premises on which an insect or pest mentioned in the schedule to this Order exists, shall forthwith notify the fact, with particulars of the time and place of discovery, to the officer appointed by the local authority to receive such notices; or, if no such officer has been appointed, to the Board; and, where practicable, a specimen of the insect or pest shall aceompany the notice.

"(2) An officer of a local authority who receives a notice under this article shall forthwith report the fact to the local authority.

"(3) The local authority, on receiving in any manner notice of the existence or apparent existence of an insect or pest mentioned in the schedule to this Order shall forthwith transmit the information to the Board, and take such steps as may be necessary to determine to what extent the insect or pest exists.

\section{"Powers of Extry.}

" 2. $\Lambda$ n inspector or other officer appointed in that behalf by the local authority, and any inspector of the 
Board may, upon production if so required of his appointment or authority, enter any premises on which he has reason to believe that an insect or pest mentioned in the schedule to this Order exists or has recently existed, and examine any plant, fruit, crop, seeds, tubers, bulbs, layers, or euttings on such premises.

\section{“Action to be Taken by lasal Authority.}

"3.-(1) An inspector or other officer of the local authority or of the Board, acting under their direction, maly at any time and from time to time, by a notice served on an occupier of premises on which an insect or pest mentioned in the scliedule hereto exists, or recently has existed, require him to adopt such measures for prevention of the spread of the insect or pest as are specified in the notice.

" (2) Where a local authority have consented to pay compensation for such destruction, the notice under this article inay require the occupier of premises on which an insect or pest mentioned in the schedule hereto exists or recently has existed, to destroy by burning or other effeetive method all or any of the plants, fruit, or crops on the premises, and the local authority shall pay compensation for such destruction, subject and according to the provisions in that behalf of the Destructive Insects and Pests Acts, 1877 and 1907.

"(3) A notice under this article may prescribe the time when within which the arloption of any measure thereby prescribed shall be completed.

" (4) An occupier may appeal to the Board against a notice, served on him under this article by an inspector or other officer of the local authority, and the Board may, after consultation with the local authority, cancel the notice or modify its recpuirements in such manner as the Joard think fit.

"(5) For the purpose of this Order a notice shall be deemed to be served on a person if it is delivered to him personally or left for him at his last known place of abode 
or business, or sent through the post in a letter addressed to him there, and a notice or other document purporting to be signed by an inspector or other officer of a local authority or of the Board shall be prima facie evidence that it was signed by him acting under the directions of the local authority or the Board, as the case may be.

"Penalty on Sale or Use for Planting of Diseased Seeds, Etc.

“4. Every person who shall knowingly use, or sell for use, for planting any plant, seed, tuber, bulb, layer, or cutting attacked by an insect or pest mentioned in the scherdule to this Order, or any seed, tuber, bulb, layer, or cutting which has been derived from a plant so attacked, and is capable of spreading the insect or pest, shall be liable on conviction to a penalty not exceeding $£ 10$.

\section{"Prohibition of Sale of Speciness.}

" . It shall not be lawful, except with the written permission of the Board, to import, sell, or offer for sale a living specimen of any insect or pest mentioned in the schedule to this Order.

\section{"Pexalties.}

"6. Every person shall be liable on conviction to a penalty not exceeding $£ 10$ who-

"(1) Knnowingly fails to give such notification as is required by Article 1 of this Order; or

“(2) Fails to adopt such measures for prevention of the spread of the disease as are specified in a notice served on him under this Order; or

" (3) Wilfully obstructs or imperes any inspector or other officer when acting under this Order; or

"(4) Imports, sells, or offers for sale an insect or pest in contravention of this Order.

\section{"Notification of Orderr.}

“ 7 . This Order shall be published by the local authority in accordance with any direction given by the Board. 


\section{" lievoration of ()liner.}

“ 8. The Destructive Insects and Pests Order of 1908 is hereby revolied.

\section{" Execution of the Order.}

"9. Each local authority shall carry into effect this Order within their district, and shall appoint such inspectors or cther officers for that purpose as may be necessary.

\section{“ SCHEDULE.}

“INencts axd Pests to which this Order Applies.

"The Vine Louse (Phylloxera vastatrix, Planchon).

"The San José Scale (Aspidiotus perniciosus, Comstock).

"The Mediterranean Fruit Fly (Ceratitis capitata, Weidemann).

"The Colorado Beetle (Doryphor'a decemlineata, Say).

"The Large Larch Sawfly (Nematus erichsonii, Hartig).

"The Potato Moth (Lita solanella, Boisduval).

"The Gipsy Moth (Liparis [Ocneria] dispar. Linné).

"The Brown Tail Moth (Euproctis chrysorrhea, Limné).

"The Nun Moth (Liparis monacha, Limné).

“ The Cherry Fly (Rhagoletis cerasi, Limné).

"The Narcissus Fly (Merodon equestris, Fabricius).

"Black Knot (Plowrightia morbosa, Saccardo).

" Wart Disease or Black Scab of Potatoes (Synchitrium endobioticum, Percival).

"Tomato Iseaf Spot (Septoria lycopersici, Spegazzini).

" Melon or Cucumber Canker (Mycosphorella citrullina, Grossenbacher).

"American Pear Blight (Micrococcus amylovorus. Burrell).

"American Gooseberry Mildew (Spharotheca mors-ura, link).'

[N.13.- Several of the above-named pests are not deseribed in the foregoing pages partly beciuse the volume was already prepared for press when the Oriler was issued, and, further, because it is mlikely that those not mentioned will ever get established in this country ; anyway, we kopenot. - T. W. S.] 


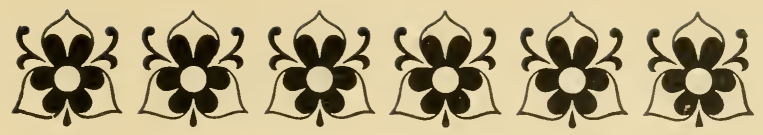

\section{N D E X.}

PAGE

PAGE

Abol Insecticide ... $\ldots . . . . \quad 32$

American Blight ... ... ... 54

Gooseberry Mildew ... 103

Potato Disease ... ... ... 204

Potato Scab _.. ... ... 204

Ammoniacal Copper Carbo$\begin{array}{llll}\text { nate Solution } & \ldots & \ldots & 26\end{array}$

Anthracnose of the Rose... 242

Anti-Fungoid Winter Wash 30

Ants and Rose Trees ... 232

in the Flower Garden ... 210

in Greenhouses ... ... 249

Aphides, Apple ......$\quad \ldots .56$

in Greenhouses ... ... 250

on Rose Trees ... ... ... 234

on Peach Trees ... ... 114

on Plum Trees ... ... ... 123

Apple Aphides $\quad . . \quad \ldots . \quad \ldots \quad 55$

Bark Beetle ... ... ... 73

Blossom Weevil ... ... 57

Diseases of the $\quad$.. $\quad$... 79

Leaf Blister Moth ... ... 71

Leaf Miner $\quad . . \quad \ldots \quad \ldots \quad 71$

$\begin{array}{llllll}\text { Mildew } & \ldots & \ldots & \ldots & \ldots & 79\end{array}$

Pesto ... ...

$\begin{array}{llllll}\text { Sawfly } & \ldots & \ldots & \ldots & \ldots & 58\end{array}$

$\begin{array}{lllllll}\text { Scab } & \ldots & \ldots & \ldots & \ldots & \ldots & 79\end{array}$

$\begin{array}{llllll}\text { Sucker } & \ldots & \ldots & \ldots & \ldots & 60\end{array}$

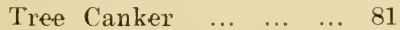

$\begin{array}{llllll}\text { Tree Mite } & . . & \ldots & \ldots & \ldots & 61\end{array}$

Apricot, Brown Rot Disease $\begin{array}{llllll}\text { of the } & \ldots & \ldots & \ldots & \ldots & 91\end{array}$

Diseases of the $\begin{array}{llll}\ldots & \ldots & \ldots & 91\end{array}$

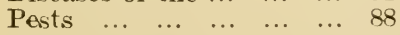

$\begin{array}{lllll}\text { Apterite, Cooper's } & \ldots & \ldots & 33\end{array}$

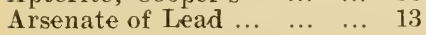

of Lead, "Carlton ", $\quad$... 32

of Jead Wash ... ... ... 20

Artichoke Ieaf Spot Disease 184

Ash Bark Beetle, The ... 274

$\begin{array}{lllllll}\text { Scale } & \ldots & \ldots & \ldots & \ldots & \ldots & 274\end{array}$

Asparagus Beetle, The ... 155

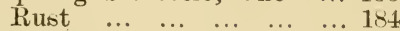

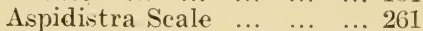

Aspidistras, Brown Spots on

Leaves of $\quad \ldots \quad \ldots \quad \ldots 267$

Bean Aphis $\quad \ldots \quad \ldots c \quad \ldots \quad \ldots 155$

Pod Canker Disease ... 184

$\begin{array}{llllll}\text { Rust } \quad \ldots & \ldots & \ldots & \ldots & \ldots & 185\end{array}$

$\begin{array}{llllll}\text { Thrips } & \ldots & \ldots & \ldots & \ldots & 171\end{array}$

Bedeguar Gall Fly on Roses 235

Beet and Mangold Rot

Disease ... $. . .6 . \ldots . . .185$

Carrion Beetle, The …157

or Mangold Fly, The ... 158

Rust Dicease of the ... 185

Big Bud Mite of the Black

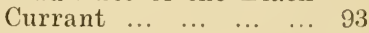

Birds, Destructive and

Friendly $\quad \ldots . \quad \ldots \quad \ldots 291$

Black Rot Disease of the

Grape Vine ... ... ... 147

Spot Disease of Tomatoes 140

Stripe in Tomatces ... ... 139

Bladder Plum Disease ... 126

Board of Agriculture Pests Order

Bordeaux Emulsion, The

Woburn ... ... ... 25031

$\begin{array}{llllll}\text { Mixture } & \ldots & \ldots & \ldots & \ldots & 24\end{array}$

Paste, Woburn $\quad . . \quad$... 31

Brown Rot, The ... ... $\quad . . .83$

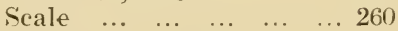

Stripe in Tomatoes ... 138

-tail Moth. The ... ... 61

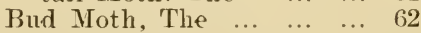

Buff-tip Moth, The $\ldots$... 276

Bulh Diseases $\quad . . . \quad \ldots . . .226$

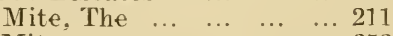

$\begin{array}{lllllll}\text { Mites } & \ldots & \ldots & \ldots & \ldots & \ldots & 252\end{array}$ 
Calbage Aphis $\quad \ldots \quad \ldots . \quad \ldots \quad 158$

Black Rot Disease of the 186

Caterpillars intesting the 161

Dinealse, Seedling ... ... 19s

lea, Blue ... ... ... 158

Fly, Tho $\ldots . . . . \quad \ldots . . .159$

Giall Weevil, The ... ... 179

l'owdered-wing Fly, The 160

White Rust Disease of the 186

Canker Disease in Apple

$\begin{array}{llllll}\text { Trees } & \ldots & \ldots & \ldots & \ldots & 81\end{array}$

in Rose Trees ... ... ... 243

Camellia, Diseases of the ... 267

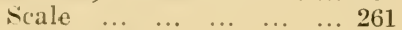

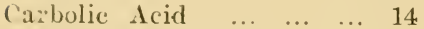

$\begin{array}{llll}\text { Carbonate of Potash } & \ldots & \ldots & 12\end{array}$

('arbon Disulphide $\ldots . \quad \ldots \quad 12$

Carbo-Nicotyl, Vosis is ... 33

Carnation Diseases ... ... 226

Maggot, The ... ... ... 211

Carrot Dizease $\quad . . . \quad \ldots . . .186$

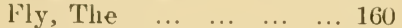

Caterpillars Injurious to

Vegetable Crops ..... .161

in the Flower Garden ... 213

on Rose Trees ... ... ... 236

Cats as Garden Enemies ... 293

Caustic Alkali Wash ... 15

$\begin{array}{lllll}\text { Caustic Soda } & \ldots & \ldots & \ldots & 12\end{array}$

Celery Fly, The ... ... ... 164

Celery Leaf Blight ... ... 187

Celery Stem-Fly, The ... 166

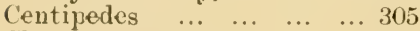

Chafer Beetles ...

Cherry Aphis, The ... ... 88

Clerry Leaf Blight Disease 93

Leaf Spot Disease ... ... 92

$\begin{array}{llllll}\text { Mildew } & \ldots & \ldots & \ldots & \ldots & 92\end{array}$

Ireaf Scorch Disease ... 91

$\begin{array}{lllllll}\text { Fests } & \ldots & \ldots & \ldots & \ldots & \ldots & 88\end{array}$

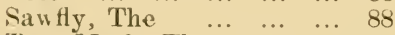

Tree Moth, The ... ... 90

Chrysanthemum Leaf-mining

Maggot, The ... ... ... 255

Ireaf Rust Dinease ... ... 268

Ireaf Spot Disease ... ... 270

Mildew $\quad \ldots \quad \ldots \quad \ldots \quad \ldots 270$

Plant Bugs injurious to the 258

Sclerotinia Disease of the 273

Clouded Drab Moth, The... 71

Clubicide, Cross's $\quad . . \quad \ldots . \quad 32$

Club Root Disease ... ... 187

Cockchafer Beetle, The 160

$\begin{array}{llllll}\text { Cockroaches } & . . & \ldots & \ldots & \ldots & 252\end{array}$

Codling Moth, The $\ldots . . \ldots 63$

Colorado Beetle, Thie ... ... 200

Common Tortrix Moth, The 71

Cooper's V1 Fluid ... $\ldots .29$

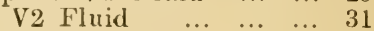

$\begin{array}{llll}\text { Copper Carbonate } & \ldots & \ldots & 27\end{array}$

$\begin{array}{llllll}\text { Sulphate } & \ldots & \ldots & \ldots & \ldots & 14\end{array}$

Coral Spot Disease $\quad \ldots \quad \ldots . \quad 85$

$\begin{array}{llllll}\text { C. icketo } & \ldots & \ldots & \ldots & \ldots & 253\end{array}$

Cuckoo-spit or Froghopper... 214

Cucumber Leaf-spot Disease 190

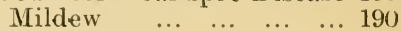

Rot Disease $\quad \ldots . \quad \ldots \quad \ldots 192$

Cucumbers, Eelworms in ... 166

Cupram Fungicide ... ... 27

Currant Anthracnose _.. 106

$\begin{array}{llllll}\text { Aphides } & \ldots & \ldots & \ldots & \ldots & 94\end{array}$

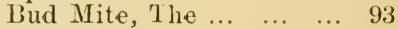

Clearwing Moth, The ... 95

Coral Spot Disease of the 106

Diseases of the $\quad \ldots \quad \ldots 103$

Leaf-spot Disease of the... 106

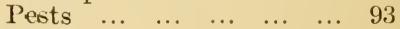

Pug Moth, The $\quad \ldots \quad$... 97

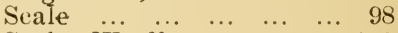

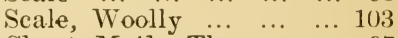

Shoot Moth, The $\ldots{ }^{2}$. 97

Cyaniding Apparatus ... 51

$\begin{array}{lllll}\text { Materials for } & \ldots & \ldots & \ldots & 49\end{array}$

$\begin{array}{llllll}\text { Process of } & \ldots & \ldots & \ldots & \ldots & 48\end{array}$

$\begin{array}{lllll}\text { Cyllin Soft Soap } & \ldots & \ldots & \ldots & 32\end{array}$

Damping-off Fungus $\ldots \quad \ldots 271$

December Moth, 'The ... ... 70

Devil's Coach Horse Beetle,

$\begin{array}{lllllll}\text { Th } & \ldots & \ldots & \ldots & \ldots & \ldots & 306\end{array}$

Diseases of Forest Trees ... 289

of Fruit $\ldots . \ldots \quad 79$ to 154

of Greenhouse Plants ... 267

of Hardy Plants ... ... 226

$\begin{array}{lllll}\text { of Vegetables } & \ldots & \ldots & \ldots & 184\end{array}$

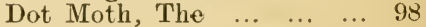

Earwige in the Flower Gar-

$\begin{array}{lllllll}\operatorname{den} & \ldots & \ldots & \ldots & \ldots & \ldots & 216\end{array}$

Eelworms in Cucumber.. .166

$\begin{array}{lllll}\text { in Tomatoes } & \ldots & \ldots & \ldots & 136\end{array}$

Elm-bark Beetle ... ... ... 277

Elm Trees, Caterpillars In-

$\begin{array}{lllllll}\text { juring } & \ldots & \ldots & \ldots & \ldots & 276\end{array}$

Ermine Moth, Small, The 74 
Euonymus Nildew

Eyed-Hawk Moth, The

Ferns, Pesto of

Scale Insects infesting ... 261

Fig, Anthracnese of the ... 110 Diseases of the $\quad \ldots \quad \ldots 110$ $\begin{array}{llllll}\text { Mould } & \ldots & \ldots & \ldots & \ldots & 110\end{array}$

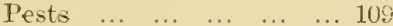

Tree Canker Disease of the 110 Figure-of-Eight Moth, The 64 Filbert Bud Nite, The ... 110 Flower Garden, Pests of the 210 Flowers of Sulphur ... $\quad . .2 \quad 28$ Forest Tree Pestos ... ... 274 Friendly Insecto, etc. ... 305 Frog as a Garden Friend ... 306 Fruit Tree Beetle, The ... 66 Tortrix, The $\quad \ldots \quad \ldots 6$... 66 Wash, MacDougall's ... 30 Fruit Trees, Diseane of Young 86 Fumers, MacDougall's ... 34 Fumigants for Greenhouses 34 Fumigating, Mode of $\ldots .44$

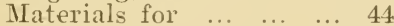
Outdoor Crope ... Fumigator, XL.-ALL, The 34 Fumigen, Strawson's ... $\quad . . \quad 34$ Fungicides, List of . . 11, 24 $\begin{array}{lllll}\text { Proprietary } & \ldots & \ldots & \ldots & 29\end{array}$

Garden Spider, The ... ... 307 Gishurot Compound $\ldots$. . 33 Goat Moth, The $\ldots . \ldots . \quad \ldots \quad 67$ Gold-tailed Moth, The ... 70 Gooseberry Black Knot

Disease, The $\ldots \quad \ldots \quad \ldots 107$ Die-back Discace, The ... 107 Diseases of the ... ... ... 103 Leaf Cluster-Cup Disease of the ... $\quad \ldots 108$ Leaf Nildew of the ... ... 108 Pests of the $\quad \ldots \quad \ldots \quad \ldots \quad$... 93 Red Spirler, The $\quad \ldots \quad \ldots 100$ Scale, The $\quad \ldots . \quad \ldots \quad \ldots \quad 98$ Grape Moth, The _.. ... 144 Great Brindled Beauty

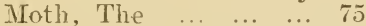
Greenfly in Greenholles ... 250 in the Flower Garden ... 210 on Rose. ... ... ... ... 234 ou Tomatces
Greenhouse Pesto

Greenhouses, Cubical Capacity of, Ascertaining . .. 45 Green-leaf Treevil, The ... 68 Green Pug Moth, The ... 71 Grey Trident Moth, The ... 70 Gumming Disease, 'The ... 126 Gummosis Disease in Plums, etc.

Hare and Rabbits ... ... 296

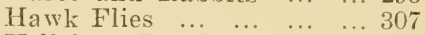

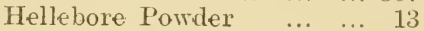

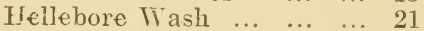

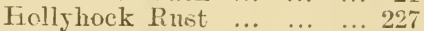
IIolly-leaf Miner $\quad \ldots \quad \ldots \quad \ldots \quad \ldots 279$ Hydrocyanic Gas $\quad \ldots . \quad \ldots \quad 11$

Ichneumon Fly, The ... ... 308 Insecticides, List of $\ldots .11,15$ $\begin{array}{lllll}\text { Proprietary } & \ldots & \ldots & \ldots & 29\end{array}$

Insecticide Sheets, MacDongall's

34

Iron Emulsion, Woburn $\ldots .31$

$\begin{array}{llllll}\text { Sulphate } & \ldots & \ldots & \ldots & \ldots & 14\end{array}$

Sulphate Solution $\quad \ldots$ zs

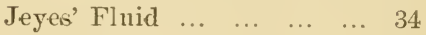

Kerosene as an Insecticide 13 $\begin{array}{llllll}\text { Emulsion } & \ldots & \ldots & \ldots & \ldots & 22\end{array}$

Isilogrub, Peak's $\quad \ldots \quad \ldots \quad 33$

Lacewing Fly, The ... ... 309

Lackey Moth, The $\quad \ldots \quad \ldots \quad 68$

I arch Aphis, The $\quad \ldots \quad \ldots 281$

Larch, Canker, Disease of

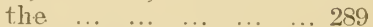

Sawfly, Large, The ... ... 282

Ladybird Beetles ... ... 310

Lappet Moth, The ... ... 70

Lawn Weeds, Eradicating... 303

Leaf-cutting Bee, The … 237

Leaf-hopper's $\ldots{ }^{2}$...

Leaf-mining Naggots 255, 218

Leaf-scald Fungus ... ... 87

Leather-jacket Grub, The... 166

Lethorion Vapour Cone, The 34

Lettuce Flv, The $\quad \ldots \quad \ldots 167$

Letfuce Mildew, The _.. 192

Root Aphis $\quad \ldots \quad \ldots \quad \ldots 167$

Jichon and Noeñ 


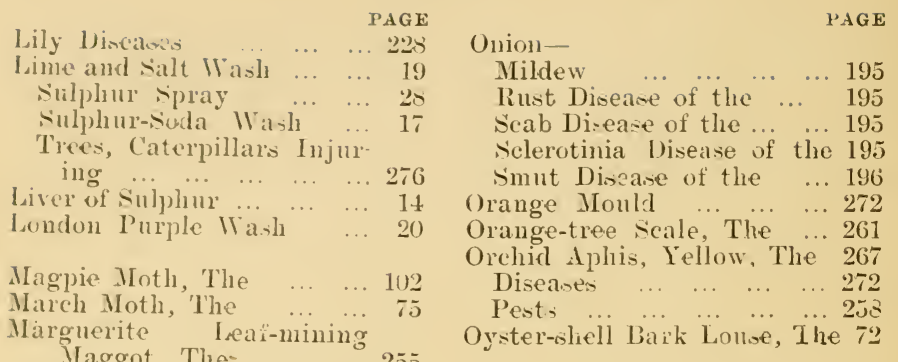

Mealy Bug in Greenliousco 256 on Vines $\quad . . \quad \ldots . . .144$

Melon Leaf Blotch, The... 190 Mildew, The ... ... ... 190

Mice and Voles

Mildew $\ldots . \ldots .3,24,245,271$ on Grape Vines ... ... 151

$\begin{array}{llllll}\text { Millepedes } & \ldots & \ldots & \ldots & \ldots & 167\end{array}$

$\begin{array}{llllll}\text { Mint Rust } & \ldots & \ldots & \ldots & \ldots & 167 \\ & \ldots & \ldots & 193\end{array}$

Iole Cricket, The ... ... 219

$\begin{array}{lllllll}\text { Moles } & \ldots & \ldots & \ldots & \ldots & \ldots & 298\end{array}$

Mottled Umber Moth ${ }^{\text {U... }} 75$

MInshroom Beetles ... ... 169

$\begin{array}{lllll}\text { Di.ieare, il } & \ldots & \ldots & \ldots & 169 \\ & & \ldots & 193\end{array}$

Mnssel Sicale, The $\quad \ldots .67_{1}$

Naptho Nicotyl, Voso's _.. 33

Narciesus Fly, The ... ... 220

Nectarine, Divares of the... 114 Pests of the $\quad \ldots \quad \ldots .113$

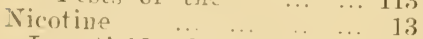

Insecticide, XL.-1LL $\ldots .33$

$\begin{array}{lllll}\text { Niquas, Corry's } & . . & \ldots & \ldots & 32\end{array}$

Nut-leaf Blister MIoth, The 111

Nut-leaf Treevil, The ... ... 111

Nut, Pentis of the ... ... 110

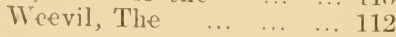

Oak, Cialls on Leaves of the 279

Gipsy Moth Larve Injurin

Ieaf Roller iIoth, The ... 283

Ninn or Black Areh Moth

Oak Trees, Caterpillars Injuring

Oleander Scale, Thic

Onion Fly, The

Prony, Disearses of the ... 228

Paraffin Foft-soap Eimulsion 30

Palm Scale, The ... ... ... 261

Palms, Brown spots on

Leaves of $\quad \ldots . \quad \ldots \quad \ldots 267$

Paris Green Ineecticide ... 13

I aris Green IVash ... .. 20

Parsnip, Mildew of the ... 197

Pea and Bean Thrip; ... 171

Blight, seesling ... ... 198

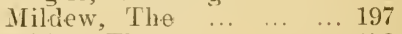

Midge, The $\quad \ldots . \quad \ldots \quad \ldots 172$

Moth, The $\quad . . \quad \ldots . . .173$

Seed Treevil, The ... ... 173

Spot Disease of the ... ... 197

Werevils $\quad \ldots . \quad \ldots \quad \ldots . . .174$

Peacli, Direases of the ... 114

Leaf-enrl Disease of the.. 114

Pests ... ... ... ... ... 113

Scale Insects infesting tlie 113

Pear, Diseaves of tlec ... 122

Leaf Blinter Hite, The... 122

Ireaf Blister Moth, The ... 116

Treaf Cluster ('up Disease

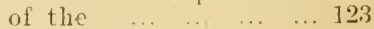

Midge, The $\quad \ldots \quad \ldots \quad \ldots 117$

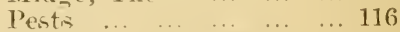

Sawfly, Social, The ... 118

Scab Disease of the ... ... 123

Pepper-anl-salt Moth, The 71

Permanganate of Potash ... 23

Phrlloxera, The Vine ... 147

Pine Beetle. The ... ... ... 28.

Bud Tortix YIoth, The ... 284

Sawfly, The $\quad \ldots . \quad \ldots \quad \ldots 284$

Trepvil. The ...... . 285

Pitl Moth, The . . . . ... 72 
Plant Bugs ... ... ... ... 258

Plum, Aphicles Infesting the 123 Diseases of the $\quad \ldots \quad \ldots 126$ Leaf Blight Disease of the 93 Maggot, Red, The ... $\quad . . .125$

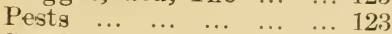

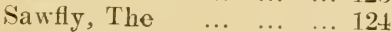
Weevil, The $\quad \ldots . \quad \ldots \quad \ldots .125$ Poplar, Puss Moth Infesting 286 $\begin{array}{lll}\text { Potasium Carbonate ... } & \ldots & 12\end{array}$ $\begin{array}{llllll}\text { Sulphide } & \ldots & \ldots & \ldots & 14, & 26\end{array}$ Potato, Black Leg Disease $\begin{array}{llllll}\text { of the } & \ldots & \ldots & \ldots & \ldots & 204\end{array}$ Black Scab Disease of the 208

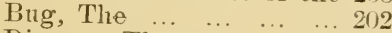
Disease, The $\ldots$. ... 2105 Diseares of the ... ...2 204 Frog Fly, The $\ldots . . . \quad \ldots 202$ Leaf curl Disease of the... 204 Leaf-spot Disease of the 205 $\begin{array}{lllllll}\text { Pests } & \ldots & \ldots & \ldots & \ldots & \ldots & \ldots\end{array}$ Rot Disease of the ... ...2 206 Scab, American, The ...204 Scab Disease of the ... 206 Sclerotinia Disease of the 207 Spindle Disease of the ... 208 Wart or Black Scab Disease of the

Powder Distributors 208 Insecticides

Pyrethrum Powder

Quassia

and Soft Soap ...

Rabbits and Hares

Radish Fly, The

Mildew, The

Raspberry Aphis, The

Beetle, The

128

Diseases of the

129

Moth, The ...

135

Pests

131

Sawfly, The

Spot Divease of the

Rats

Weevil, The

12

132

135

132

Red Spider …

on

on Pear

on Tomatoes

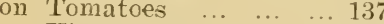

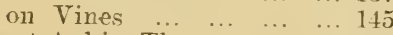

Root Aphio, The
Root-Knot Disease of Toma-

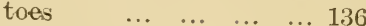

Rose Beetle, The ...

Diseases of the $\quad . .2 . \ldots 242$

Mildews of the $\ldots 243,245$

Leaf Scorch Disease of the 247

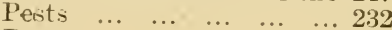

$\begin{array}{lllllll}\text { Rust } \quad \ldots & \ldots & \ldots & \ldots & \ldots & 247\end{array}$

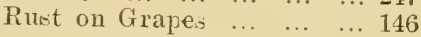

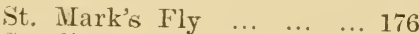

Sawtlies and Roses ... ... 239

Scale Insects on Fig Trees 109 Insects on Greenhouse

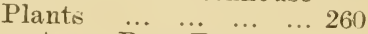
Insects on Rose Trees ... 241 Scarce Umber Moth, The ... 75

Shot-borer Beetle, The ... 73

Shot-hole Fungus on Peach Trees

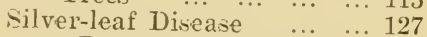
on Peach Trees ... ... 115

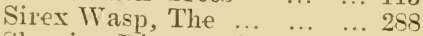

Sleeping Disease of Tomatces 141

Slugene, Stanley's $\quad \ldots \quad \ldots \quad 32$

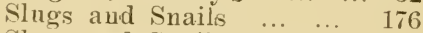

Slugs and Snails in Flower Garden ... $\ldots$... $\ldots 220$

Small Brindled Beauty Moth, $\begin{array}{llllllll}\text { The } & \ldots & \ldots & \ldots & \ldots & \ldots & 75\end{array}$ $\begin{array}{lllll}\text { Snails and Slngs } & \ldots & \ldots & \ldots & 176\end{array}$ Snails and Slugs in the Flower Garden ... ... 220

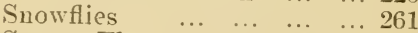

Snowy Fly on Tomatoe; ... 137

Sodalin, Strawson's ...

$\begin{array}{llllll}\text { Soft Soap } & \ldots & \ldots & \ldots & \ldots & 12\end{array}$

Soil Disinfectants $\quad \ldots . \quad \ldots \quad 23$

Spinach Mould, The ... ... 198

Sprayer, Jeyes' Kinapsack... 38

The "Abol"

The "Alpha" Knapsack 38

The "Syphonia" "... ... 37

The "Vermorel" Knapsack 38 Sprayers, Hand ... $\ldots . . . . \quad 38$

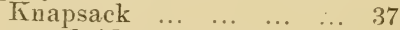

Spray-fluid, A Vinter $\quad \ldots . .18$

Spraying Apparatus ... $\quad \ldots \quad 35$

$\begin{array}{llllll}\text { Machines } & \ldots & \ldots & \ldots & \ldots & 35\end{array}$

Machines, Strawson's $\quad \ldots \quad 37$

Machines. Weeks' ... $\ldots .35$

Spraving, How to do it ... 41 
PAGE

Firingtail $\quad \ldots . \quad \ldots \quad \ldots \quad \ldots .262$

-ipruce Gall Aplis, The ... 256

cirawberry Aplis, The ... 133

I) iveares of the $\quad \ldots \quad \ldots 135$

Button lluth, Ihe ... ... 133

leat-opot Dincatse of the 135

Mildew $\quad$...

Pests

Snail, The

-iulpliate of Copper

of Copperats

sulphate of Iron ... $\quad . . \quad \ldots \quad . \quad 14$

silplide of Potassium ... 14

$\begin{array}{lllllll}-m p h u r & \ldots & \ldots & \ldots & \ldots & \ldots & 14\end{array}$

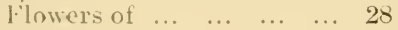

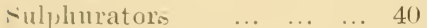

Fweet Pea Blight ... ... 229

$\begin{array}{llllll}\text { Mildew } & \ldots & \ldots & \ldots & \ldots & 229\end{array}$

spot Diseare of the ...231

Streak Disease of the ... 231

Syringe, Cooper's Patent ... 39

Reid's Patent ... $\quad . . \quad$... 39

Stone's Plunger $\quad$... $\quad$... 39

'Tle "Abol" " ..

$\begin{array}{llllll}\text { syringes } & \ldots & \ldots & \ldots & \ldots & 39\end{array}$

Sycamore, Leaf Blotel

Diseare of the $\quad . . \quad \ldots 289$

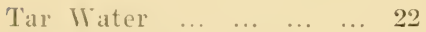

Testacella slug, The ... ... 311

Thrips attacking Tegetables 176

on Fig Trees ... ... ... 109

(1) Greenlonse Plants ... 263

(om Peach Trees ... ... 114

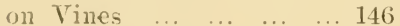

'liger Beetle. The ... ... 312

Toud as a Giarden Friend ... 306

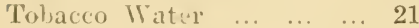

Tomato, Diseases of the ... 138

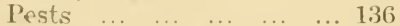

Tomatnes, Cracked Fruits of 140

IVarty Veins on Leaves of $1+2$

Turnip, Bacterial Disease of the

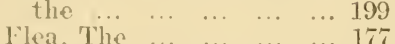

fiall Weeril, The $\ldots . . . .179$

I.eaf-miner's $\quad \ldots \quad \ldots \quad \ldots .178$

siwfly, The _... ... ... 181

Twig cutting Weevil, The ... 75

Vapourer Notli, The

121
PAGE

Vaporite, strawson's ... ... 33

Vegetables, Diseases of ... 184 Pests of $\ldots . . . .6 .155$

Violet, Dioeases of the ... 232 $\begin{array}{llllll}\text { Fungicide } & \ldots & \ldots & \ldots & \ldots & 27\end{array}$

Ground Beetle, The ... 313

Vine, Diseases of the ... ... 147

Leaves, ITarts on $\ldots . . .147$

Louse, The $\quad . . \quad \ldots . \quad \ldots \quad 147$

Pests of the $\ldots$...

Vines, Cushion Scale In-

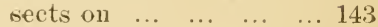

Voles and Mice ... ... ... 296

Wash, A simple $\quad . . \quad \ldots \quad \ldots \quad \ldots \quad 18$

$\begin{array}{lllllll}\text { Washes } & \ldots & \ldots & \ldots & \ldots & \ldots & 15\end{array}$

Walmut Pests $\quad . . \quad \ldots . \quad \ldots 112$

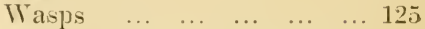

Theed Killers, Recipes for

Making ... ... $\quad \ldots . \quad \ldots 301$

Weeds on Paths ... ... ... 299

Weavilo attacking Greenhouse Plants ... ... ... 264

Injurious to Roses ... ... 242

Willow Beetle, The ... ... 287

Willow, Puss Moth Infest-

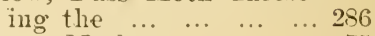

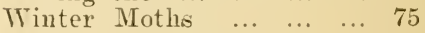

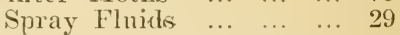

Wash for Indoor Fruits... 17

Wireworms and Tomatoes 138

and Vegetables ... ... 182

Witches' Brooms ... ... 290

Woburn Bordeaux Emulsion 31

Bordeaux Paste ... ... 31

Iron Emulsion ... ... ... 31

Tobacco Extract ... ... 31

Wash Emulsiou $\quad . . \quad \ldots \quad$.. 30

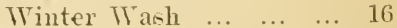

IVoodlice $\quad \ldots . \quad \ldots \quad \ldots . \quad \ldots \quad 183$

infesting Greenhcises ... 265

rood Leopard Mcth, The... Ts

Wrod Wasp, The $\ldots . . .289$

Trorms in Pots ... ... ... 265

in the Garden ... ... ... 222

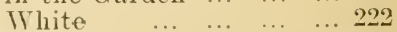

XL.-A LI Nicotine Insecticide 33

Jellow Signt Direase of the 'Tamato

142 


\section{ILLUSTRATIONS.}

PAGE

Amcrican Blight ... ...

Grootheriy llildew ... 104

Apple Aphiós ...

and Pear Scab Disease ... su

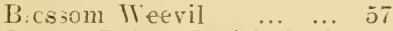

Leaves Infested with Galls is

Sawfly and Gruo $\quad \ldots \quad$... 59

Sucler and Larræ ... ... 60

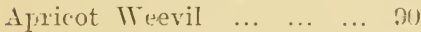

A-paragus Beetle and Larva $156^{\circ}$

Bean Aphio .. .. ... . . 156 and Yea lleevils ... ... 174

Beet Carrion Beetle ... ... 157

Brown Rot Disease ... ... 4

Browli stripe Disease of To$\begin{array}{llllll}\text { matces } & \ldots & \ldots & \ldots & \ldots & 138\end{array}$

Black Rot of Grapes ... ... 148

Spot Disease of Tomatoes 139

Bullfinches Eating Fruit Buds 292

Cabbage Aphio $\quad \ldots \quad \ldots \quad \ldots \quad 159$

$\begin{array}{lllll}\text { Butterilies } & \ldots & \ldots & \ldots & 161\end{array}$

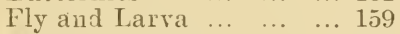

Moth and Larva $\quad \ldots . \quad \ldots 212$

Moth, Eggs of the ... ... 163

Root Gall ... $\quad . . \quad \ldots \quad \ldots \quad \ldots 180$

White Rust ... ... ... 187

Cankered Apple shoots ... 82

$\begin{array}{llll}\text { Carnation Uiseaser ... } & . . & 227\end{array}$

Carrot Fly and Larva ... 160

Cat Excluder's ... ... 294, 295

Celer'y Fly and Maggot ... 164

$\begin{array}{llllll}\text { Centipedeis } & \ldots & \ldots & \ldots & \ldots & 306\end{array}$

Cherry Black Aphis ... ... 89

Chrysantlemum Rust ... 269

Club-root Disease ... $\quad \ldots 189$

Cockchafer Beetle and Larva 166

Codling Moth and Larvæ 63

Colorado Beetle and Larva 201

Conifer Beetle ... ... ... 285
Cubical Contents of Greenhouse, Ascertaining ... 45

Cuckoo-spit or Froghopper 215

Cucumber and Melon Leaf $\begin{array}{llllll}\text { Blotch } & \ldots & \ldots & \ldots & \ldots & 191\end{array}$

Root Eelworm $\ldots$...

Currant Clearwing Moth... 96

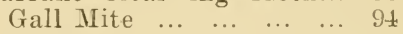

$\begin{array}{llllll}\text { Sawfly } & \ldots & \ldots & \ldots & \ldots & 101\end{array}$

Cyaniding Apparatus, A

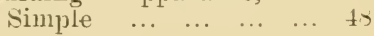

Death's Heal Moth ... ... 203

Devil's Coach Horse Beetle 307

Earwig Trap, A Simple ... 217

Fern Frond Infested with

$\begin{array}{llllll}\text { Scale } & \ldots & \ldots & \ldots & \ldots & 25\end{array}$

Figure-of-Eight Iioth and

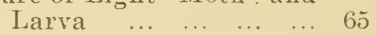

Froghopper or Cuckoo Spit 215

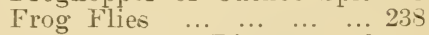

Fruit Trees, Disease of $\begin{array}{llllll}\text { Yolling } & \ldots & \ldots & \ldots & \ldots & 86\end{array}$

Galls, Artichoke, on Oak ... 278

Galls on Lime Leaf ... ... 275

$\begin{array}{llllll}\text { on Oak } & \ldots & \ldots & \ldots & \ldots & 277\end{array}$

on Poplar Leaves ... ... 276

Ghost Moth and Larva ... 162

Ghost Fly Eggo on Salvia

$\begin{array}{llllll}\text { Leaf } & \ldots & \ldots & \ldots & \ldots & 262\end{array}$

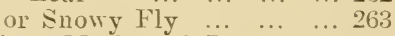

Gipsy Moth and Larva ... 280

Goat Moth and Larva ... ... 67

Gooseberry Leaf Cluster-cups 107

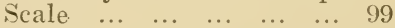

Shoots, Galls on ... ... 105

Grapes Infected with Mildew 153

Ground Beetle ... ... ... 313 
Holly-leaf Niner f.. FA $2 \diamond 1$

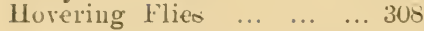

India-rubber Leaf, Diseased 266

June Bug, The $\ldots$. ... 237

Lacewing Fly and Larvie ... 309

Lackey Moth and Larva ... 69

Ladvbird Beetles and Larva 310

Leaves Injured by onalguerite Fly Larvæ ... 255

Lichen on Apple shoots ... 70

Magpie Moth, Caterpillaris $\begin{array}{lllllll}\text { of } & \ldots & \ldots & \ldots & \ldots & \ldots & 102\end{array}$ Marguerite Fly and Pupa 254 Mealy Bug ... $\begin{array}{llllll}\text { Millepedes } & \ldots & \ldots & \ldots & \ldots & 169\end{array}$ Mole Cricket $\quad \ldots . \quad \ldots \quad \ldots 218$ Mottled Umber Moth ... 235 Mouse Trap, Figure-of Four 297 Mushroom Diseace, I _.. 194 Mus:el seale on Apple Fruit 71

Narcissus Fly and Larva ... 219 Nuts Injured by Nice ... 112

Oak Roller Moth and Larvæ $2 \$ 3$

Pale Brindled Beauty Moth 77 Parnip Nildew ... $\quad . . . \quad$... 196

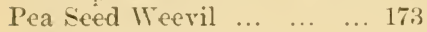

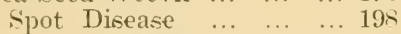
Pear Leaves Injured by Blister Mite $\ldots . \quad \ldots \quad \ldots 117$ Midge and Larva $\quad \ldots . \quad \ldots \quad 119$ Sawfly, Social ...

Pears Injured by Scab Fun$\begin{array}{lllllll}\text { gus } & \ldots & \ldots & \ldots & \ldots & \ldots & 122\end{array}$

Peach Leaf-curl $\ldots$. . $\quad \ldots \quad 114$

Pith Moth and Larva ... 73

Plum Aphides, A Colony of 124

Potato, Black Scab Direase of the

Bug Infesting the ...

Frog Fly of the

Scab Dinease of the

Pusis Moth, Larra of ...

Raspberry Beetle and Larva 129
PAGE

Rowe Aphides $\quad \ldots \quad \ldots \quad \ldots 233$

Black Leaf spot Disease on

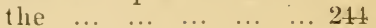
Galls on Shoots of the ... 234 Leaves Eaten by Weevils 241 Leaves Infested with Lealrolling Sawfly ... ... 240

Leares Injured by Frog

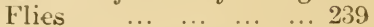
Leaf-scorch Disease of tl:e 24 ; Mildew of the $\ldots$... ... 245

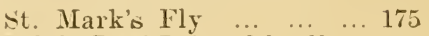
Salvia Leaf Injured by l'rog

$\begin{array}{lllllll}\text { Fly } & \ldots & \ldots & \ldots & \ldots & \ldots & 216\end{array}$

Scale Insects on Oleander... 260

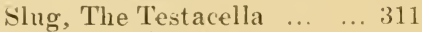

Slugo, Garden $\quad \ldots \quad \ldots \quad \ldots 221$

Sniall Ermine Moth and $\begin{array}{llllll}\text { Larve } & \ldots & \ldots & \ldots & \ldots & 74\end{array}$ Snail, The Garden ... $\ldots 220$ Strawberry Leaf Eaten by $\begin{array}{llllll}\text { Snails } & \ldots & \ldots & \ldots & \ldots & 134\end{array}$

Summer Spraying $\quad \ldots . \quad \ldots \quad 42$

Sweet Pea Blight ... ... 230

Testacella Slug $\quad \ldots \quad \ldots \quad \ldots 311$

Tiger Beetle ... $\ldots{ }^{2}$... $\quad \ldots \quad 312$

Tiger Moth and Larva ... 214

Tomato Root Eelworm ... 137

Tomatoes with Cracked Skins 141 with Warty Vein: ... ... 142

Turnip Flea Beetle ... ... 177

Gall Weeril $\quad \ldots . \quad \ldots \quad \ldots 179$

$\begin{array}{lllll}\text { Leaf-miner } & \ldots & \ldots & \ldots & 178\end{array}$

$\begin{array}{llllll}\text { Sawfly } & \ldots & \ldots & \ldots & \ldots & 181\end{array}$

Vapourer Motlı and Larva 121

Vine Mildew $\quad \ldots . \quad \ldots \quad \ldots \quad 152$

Powdery Mildew of the ... 150

$\begin{array}{llllll}\text { Viola Ruot } & \ldots & \ldots & \ldots & \ldots & 231\end{array}$

Winter Moth and Larvæ... 76 $\begin{array}{llllll}\text { Spraying } & \ldots & \ldots & \ldots & . & 36\end{array}$

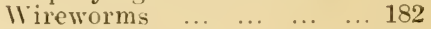

Wood Wasp

Worms, Dew or Eartl ... 223

Fellow Inderwing Moth and I arva.

\section{PNOPERTY LIBRART \\ N. C. State College}





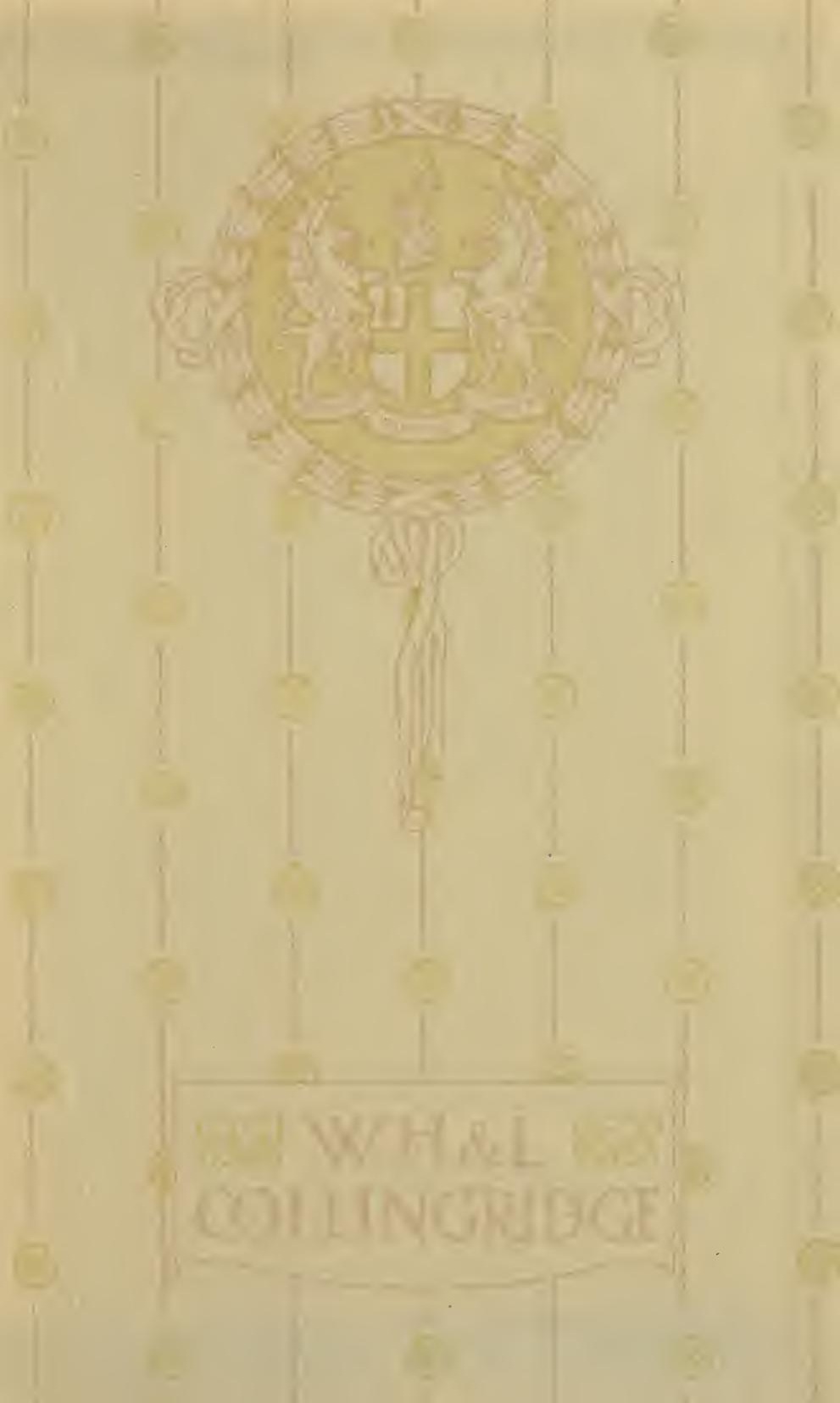


